\title{
ANÁLISE DA EXPRESSÃO GÊNICA INDUZIDA POR Diatraea saccharalis EM CANA-DE-AÇÚCAR VIA MACROARRANJOS DE COLÔNIAS BACTERIANAS
}

\author{
CARLA FERNANDA BARSALOBRES
}

Dissertação apresentada à Escola Superior de Agricultura "Luiz de Queiroz", Universidade de São Paulo, para obtenção do título de Mestre em Agronomia, Área de Concentração: Genética e Melhoramento de Plantas.

\author{
PIR A C I C A B A \\ Estado de São Paulo - Brasil \\ Julho -2004
}




\title{
ANÁLISE DA EXPRESSÃO GÊNICA INDUZIDA POR Diatraea saccharalis EM CANA-DE-AÇÚCAR VIA MACROARRANJOS DE COLÔNIAS BACTERIANAS
}

\section{CARLA FERNANDA BARSALOBRES}

Bacharel em Ciências Biológicas

Orientador: Prof. Dr. MARCIO DE CASTRO SILVA FILHO

\begin{abstract}
Dissertação apresentada à Escola Superior de Agricultura "Luiz de Queiroz", Universidade de São Paulo, para obtenção do título de Mestre em Agronomia, Área de Concentração: Genética e Melhoramento de Plantas.
\end{abstract}

P I R A C I C A B A

Estado de São Paulo - Brasil

Julho -2004 


\section{Dados Internacionais de Catalogação na Publicação (CIP) DIVISÃO DE BIBLIOTECA E DOCUMENTAÇÃO - ESALQ/USP}

\section{Barsalobres, Carla Fernanda}

Análise da expressão gênica induzida por Diatraea saccharalis em cana-de-açúcar via macroarranjos de colônias bacterianas.

$228 \mathrm{p}$.

Dissertação (mestrado) - - Escola Superior de Agricultura Luiz de Queiroz, 2004. Bibliografia.

1. Brocas (insetos nocivos) 2. Cana-de-açúcar 3. Expressão gênica 4. Resistência genética vegetal I. Título

CDD 633.61

"Permitida a cópia total ou parcial deste documento, desde que citada a fonte - O autor" 
"Quem não valorizar pequenos progressos não conseguirá obter grandes progressos. Os grandes progressos são resultado da perseverante manutenção da força de vontade. Contudo, por maior que seja a força de vontade, se a pessoa não tiver sonhos elevados e grandiosos não conseguirá realizar grandes obras. O sonho faz a mente definir um rumo visando a sua realização; e a força de vontade possibilita-nos manter vivo o sonho e perseverar até sua concretização" 
Dedico este trabalho aos meus pais, PEDRO e ROSÂNGELA, que propiciaram as condições para minha formação profissional, servindo-me de carinho, incentivo, confiança e compreensão em todos os momentos de minha vida. 


\section{AGRADECIMENTOS}

Ao Prof. Dr. MARCIO DE CASTRO SILVA FILHO, meu orientador, pela oportunidade, confiança e amizade.

Ao Dr. WILLIAN LEE BURNQUIST, gerente de fitotecnia do Centro de Tecnologia Copersucar, por ter permitido a realização deste trabalho.

Ao Dr. EUGÊNIO CÉSAR ULIAN (Seção de Biologia Molecular do Centro de Tecnologia Copersucar) pelo apoio no trabalho e pela amizade.

Ao Prof. Dr. JESUS A. FERRO, à Profa. Dra. SÔNIA M. Z. DI MAURO e aOS alunos JULIANA REGINA ROSSI, NÁDIA SUELI CICILINI DA SILVA, RAFAEL FONSECA HECK e THAIZA G. M. DA SILVA (Centro Brasileiro de Estocagem de Clones - FCAV - UNESP, Campus de Jaboticabal) pelo suporte técnico e hospitalidade.

Ao Dr. ENRICO DE BENI ARRIGONI, ao Dr. LUIZ CARLOS DE ALMEIDA e à SUELI A. PIACENTINI (Seção de Entomologia do Centro de Tecnologia Copersucar) pela cessão dos insetos utilizados neste estudo $e$ pela amizade.

À Dra. PATRÍCIA POMPERMAYER SESSO (Laboratório de Biologia Molecular de Plantas - ESALQ - USP, Campus de Piracicaba) pelo auxílio e empenho na realização dos experimentos e sobretudo pela amizade. 
Ao Prof. Dr. JOSÉ ROBERTO POSTALI PARRA e seus alunos (Laboratório de Biologia de Insetos - ESALQ - USP, Campus de Piracicaba) pelo empréstimo dos equipamentos para a montagem dos bioensaios.

Às Dras. SABRINA MOUTINHO CHABREGAS e MARIA CRISTINA FALCO (Seção de Biologia Molecular do Centro de Tecnologia Copersucar) pelo espaço e material cedidos para a realização deste trabalho.

Ao Prof. Dr. MARCELO MENOSSI e aos amigos, o Dr. FÁBIO T. S. NOGUEIRA e também o Dr. VICENTE E. DE ROSA JR. (Centro de Biologia Molecular e Engenharia Genética - UNICAMP) pela colaboração, atenção e apoio.

Aos colegas RENATO VICENTINI DOS SANTOS $e$ JULIANA DE MARIA FÉLIX (Centro de Biologia Molecular e Engenharia Genética - UNICAMP) pelos ensinamentos de bioinformática e ajuda sempre que solicitada.

Ao Prof. Dr. FLÁVIO VIEIRA MEIRELLES e toda sua equipe (Laboratório de Morfofisiologia Molecular e Desenvolvimento - FZEA - USP, Campus de Pirassununga) por terem permitido o uso de seus equipamentos para a realização deste trabalho.

Ao Prof. Dr. ANTÔNIO AUGUSTO FRANCO GARCIA (Depto. de Genética - ESALQ - USP, Campus de Piracicaba) e ao aluno de pósgraduação ANTÔNIO WILLIAMS MOITA (Depto. de Ciências Exatas ESALQ - USP, Campus de Piracicaba) pelo apoio nas análises estatísticas. 
Ao Dr. DANIEL SCHERER DE MOURA (Jovem Pesquisador do Laboratório de Biologia Molecular de Plantas - ESALQ - USP, Campus de Piracicaba) pela dedicação em revisar criteriosamente o conteúdo deste trabalho, e principalmente pelo incentivo, paciência e amizade.

Ao Prof. Dr. ANTONIO VARGAS DE OLIVEIRA FIGUEIRA (Laboratório de Melhoramento de Plantas - CENA - USP, Campus de Piracicaba), ao Prof. Dr. LUIZ LEHMANN COUTINHO (Laboratório de Biotecnologia Animal - Depto de Zootecnia - ESALQ - USP, Campus de Piracicaba), e aos seus alunos MUITO OBRIGADA pelo apoio técnico nos momentos decisivos desta tese...

Às amigas ALINE BRASILEIRO (AMÉLIA MON), ANA PAULA SALDANHA DE AGUIAR (OLÍVIA) e ROBERTA ENGELS DO NASCIMENTO (BORN) pelo ombro amigo nas horas difíceis e pelos ótimos momentos de alegria (e um brinde ao Dr. Clark!).

AOS amigos DANIELA BRIOSCHI e HENRIQUE MARQUES BARBOSA DE SOUZA pelos ótimos momentos em que passamos juntos.

Aos amigos Dr. MARCOS A. GIMENES e Dr. DARIO $A$. PALMIERI (Depto. de Genética - IB - UNESP, Campus de Botucatu) pelos ensinamentos, incentivo e amizade.

A TODOS os funcionários do Centro de Tecnologia COPERSUCAR pela amizade, apoio e solidariedade.

À minha FAMÍLIA pela compreensão nos momentos de minha ausência e pelo incentivo a cada novo rumo em que tomo nesta louca vida.

À CAPES pela concessão da bolsa de estudos, $e$ à COPERSUCAR, PRONEX, CNPQ e FAPESP pelo financiamento deste projeto. 
Aos COLEGAS do curso de pós-graduação, PROFESSORES e FUNCIONÁRIOS do Depto. de Genética, em especial, aos do Laboratório de Biologia Molecular de Plantas, pelo saudável relacionamento profissional e pessoal.

A todas as pessoas que, de forma direta ou indireta, contribuíram para a realização deste trabalho.

De maneira muito especial, agradeço ao meu amigo, amado e amante, MARCELO MATTOS CAVALLARI, pela sua colaboração e apoio na realização deste trabalho, sendo meu porto-seguro nos momentos difíceis e me inspirando e estimulando a cada novo dia. 


\section{SUMÁRIO}

LISTA DE ABREVIATURAS E SÍMBOLOS....................................... xi

RESUMO

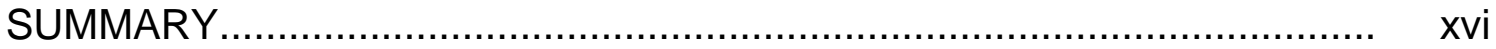

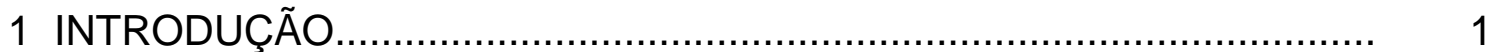

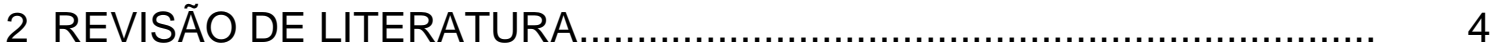

2.1 Projetos Para Obtenção de Seqüências Expressas

(ESTs - Expressed Sequence Tags)...................................... 4

2.2 Análise em Larga Escala da Expressão Gênica............................. 6

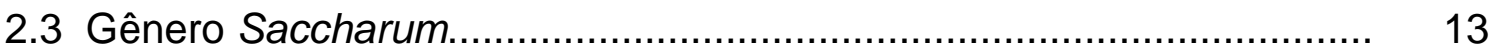

2.4 Broca do colmo Diatraea saccharalis........................................ 15

2.5 Mecanismos de Defesa das Plantas Contra Insetos Herbívoros.......... 19

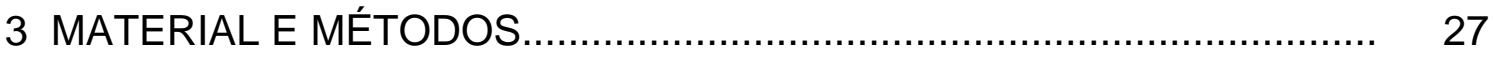

3.1 Macroarranjos de Colônias Bacterianas...................................... 27

3.1.1 Seleção de Clones para a Confecção dos Macroarranjos................. 27

3.1 .2 Confecção das Membranas.................................................. 28

3.1.2.1 Transferência das Bactérias para a Membrana de Náilon.............. 28

3.1.2.2 Crescimento das Bactérias na Membrana................................ 32

3.1.2.3 Processamento da Membrana após o Crescimento das Bactérias 32

3.1.3 Normalização das Membranas................................................ 33

3.1.3.1 Hibridização com a Sonda Overgo...................................... 33

3.1.3.2 Análise dos Experimentos para Otimização da Técnica................ 37 
3.1.3.3 Contagem do Número de Unidades Formadoras de Colônias........ 38

3.1.4 Análise dos Experimentos para Normalização com a Sonda Overgo 39

3.2 Avaliação da Expressão Gênica em Resposta a Herbivoria................. 39

3.2.1 Material Vegetal: Cana-de-açúcar................................................ 39

3.2.2 Insetos: Diatraea Saccharalis.................................................. 40

3.2.3 Ensaio Biológico................................................................. 42

3.2.4 Extração de RNA Total.................................................................. 46

3.2.5 Quantificação do RNA Total...................................................... 48

3.2.5 Preparo das Sondas e Hibridização................................................ 49

3.2.6 Hibridização dos Macroarranjos................................................... 50

3.2.7 Análise dos Dados de Expressão Gênica Responsiva a Herbivoria... 52

4 RESULTADOS E DISCUSSÃO................................................... 53

4.1 Otimização da Técnica de Macroarranjos de DNA a partir de Colônias

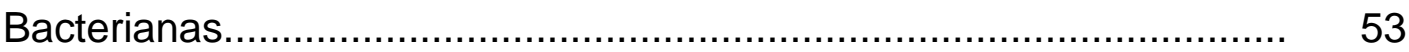

4.1.1 Determinação do Tempo de Crescimento das Bactérias em Membranas de Náilon....................................................................... 53

4.1.2 Contagem do Número de Unidades Formadoras de Colônias........... 57

4.2 Análise da Expressão Gênica em Resposta à Herbivoria.................... 58

4.2.1 Normalização com a Sonda Overgo........................................... 58

4.2.2 Normalização com as Sondas de cDNA de Cana-de-açúcar............. 59

4.2.3 Análise da Variedade SP80-3280 (Susceptível).............................. 62

4.2.4 Análise da Variedade SP81-3250 (Tolerante)................................ 80

4.3 Comparação Entre Variedade Susceptível e Tolerante........................ 94

4.4 Alguns Genes de Interesse Induzidos em Resposta à Herbivoria......... 109

4.4.1 Sinais Sistêmicos................................................................... 109

4.4.2 Proteínas de Defesa................................................................ 113

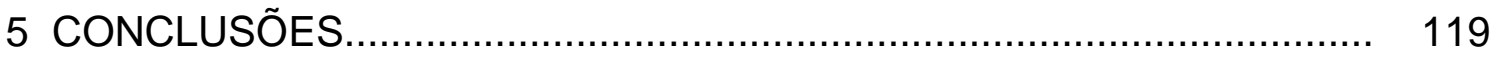

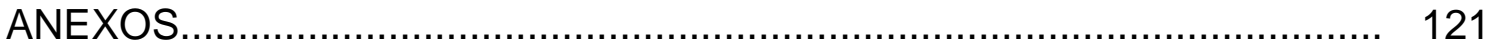

REFERÊNCIAS BIBLIOGRÁFICAS .................................................. 149

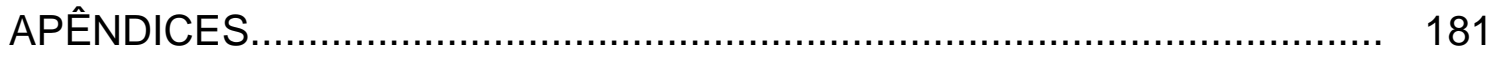




\section{LISTA DE ABREVIATURAS E SÍMBOLOS}

$\begin{array}{ll}\text { (p/v) } & \text { peso / volume } \\ (\mathrm{v} / \mathrm{v}) & \text { volume / volume } \\ \mu & \text { micro }-10^{-6}(\mu \mathrm{l}, \mu \mathrm{M}) \\ 3 \times \mathrm{C} & \text { indução pelo menos 3 vezes maior que o valor de C } \\ \text { ABA } & \text { ácido abscísico } \\ \text { ACC } & \text { 1-aminocyclopropane-1-carboxylate } \\ \text { ACO } & \text { 1-aminocyclopropane-1-carboxylate oxidase } \\ \text { AOS } & \text { alene oxido sintase } \\ \text { BRIX } & \text { teor de sólidos solúveis por cento de caldo } \\ \text { BSA } & \text { albumina de soro bovino } \\ \text { C } & \text { intensidade de sinal emitida pelas plantas controle } \\ \text { cDNA } & \text { DNA complementar ao mRNA } \\ \text { CG } & \text { Circle Grow Medium } \\ \text { CS } & \text { tratamento controle da variedade susceptível (SP80-3280) } \\ \text { CT } & \text { tratamento controle da variedade tolerante (SP81-3250) } \\ \text { CTC } & \text { Centro de Tecnologia Copersucar } \\ \text { Cys } & \text { cisteína } \\ \text { DEPC } & \text { dietil pirocarbonato } \\ \text { DNA } & \text { ácido desoxirribonucléico } \\ \text { dNTPs } & \text { deoxiribonucleotídeo trifosfato (dATP, dCTP, dTTP, dGTP) } \\ \text { DsPTP1 } & \text { dual specificity protein phosphatase 1 } \\ \text { DTT } & \text { ditioteitol } \\ \text { EDTA } & \text { ácido etileno diamino tetraacético } \\ & \end{array}$




\begin{tabular}{ll} 
ESTs & seqüências expressas (Expressed Sequence Tags) \\
F & variável do teste $\mathrm{F}$ \\
$\mathrm{G}$ & aceleração da gravidade \\
$\mathrm{g}$ & grama \\
GFP & proteína verde fluorescente (green-fluorescent protein) \\
GL & grau de liberdade \\
GSH & glutationa \\
GSK-3 & glycogen synthase kinase 3 \\
h & hora \\
IP & Image Plate \\
JA & ácido jasmônico ou jasmonato \\
I & litro \\
log & logaritmo na base 10 \\
log 2 & logaritmo na base 2 \\
longESTs & maiores seqüências expressas \\
LOX & lipoxigenase \\
m & mili - 10-3 (ml, mg, mM) \\
M & molar \\
MAP & mitogen-activated protein \\
MeJA & metil-jasmonato \\
met. 2ário & metabolismo secundário \\
met. aa. & metabolismo de aminoácidos \\
met. & metabolismo \\
MOPS & ácido 3-(N-morfolino)-propanos-sulfônico \\
mRNA & RNA mensageiro \\
MtN3 & gene nódulo-específico de Medicago truncatula \\
n & nano - 10-9 (nl, ng, nM) \\
N, S, P & nitrogênio, enxofre, fósforo \\
ND & classe gênica cujos genes têm função não determinada \\
PAL & L-fenilalanina amônia-liase \\
\hline
\end{tabular}




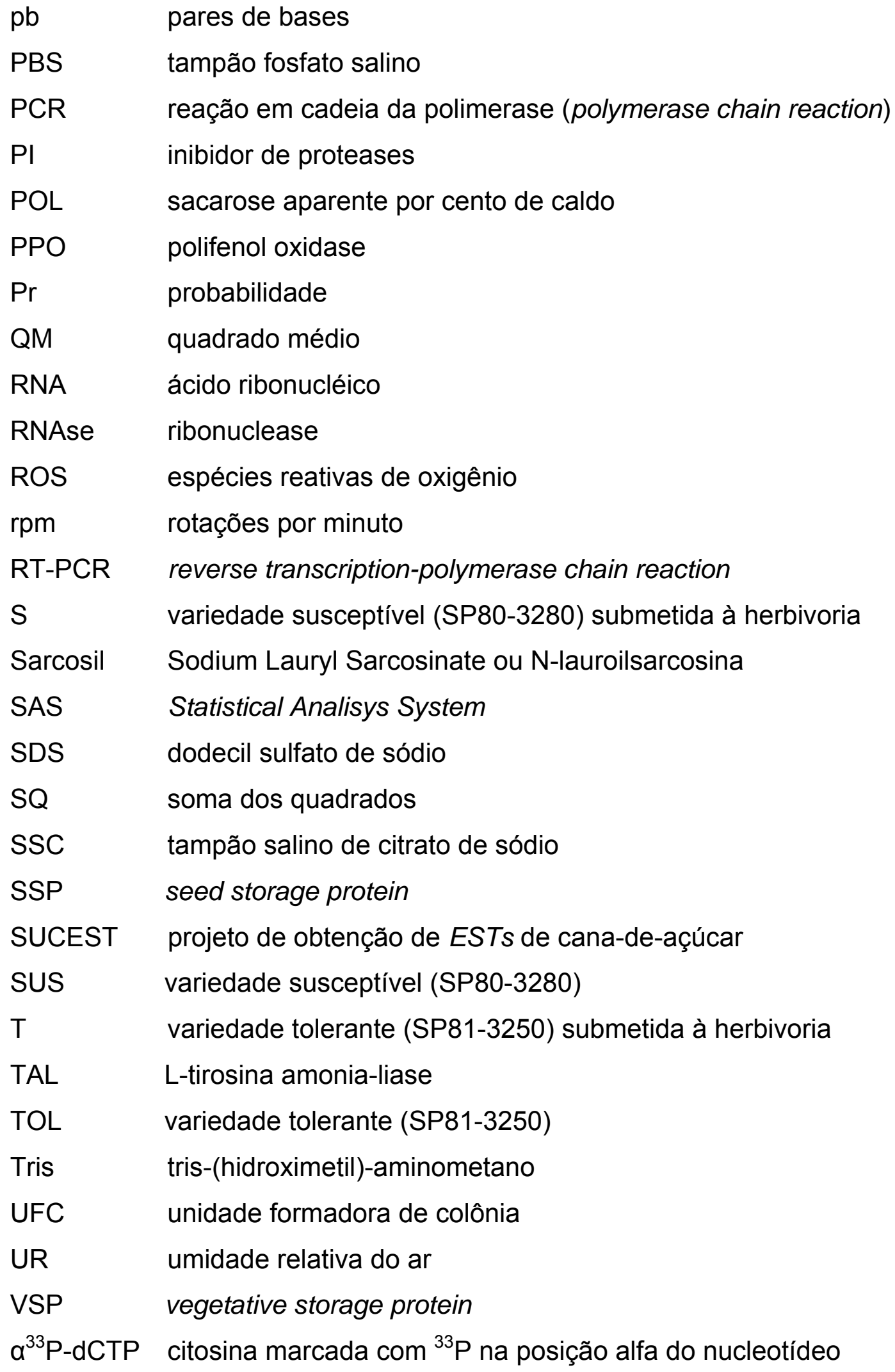




\title{
ANÁLISE DA EXPRESSÃO GÊNICA INDUZIDA POR Diatraea saccharalis EM CANA-DE-AÇÚCAR VIA MACROARRANJOS DE COLÔNIAS BACTERIANAS
}

\author{
Autora: CARLA FERNANDA BARSALOBRES \\ Orientador: Prof. Dr. MARCIO DE CASTRO SILVA FILHO
}

\section{RESUMO}

O seqüenciamento em larga-escala e a aplicação da tecnologia de seqüências expressas (ESTs) permitiram a identificação de milhares de seqüências genômicas de vários organismos. Através de projetos como o de obtenção de ESTS de cana-de-açúcar (SUCEST - Sugarcane EST Project), a tecnologia de macro e microarranjos de DNA pôde ser aplicada para o monitoramento da expressão gênica. O primeiro passo deste trabalho foi otimizar a técnica de macroarranjos utilizando-se colônias bacterianas. Os arranjos foram construídos com o auxílio do robô Q-Bot. Células bacterianas contendo clones de cDNA de cana-de-açúcar foram arranjadas em duplicata em membranas de náilon e crescidas por 6 e 12 horas. Como resultado, concluiuse que é possível estudar a expressão gênica em larga-escala usando macroarranjos de colônias bacterianas crescidas por 6 horas. Na segunda parte, o objetivo foi identificar genes de defesa em duas variedades de cana-deaçúcar (Saccharum sp.), em resposta ao herbívoro Diatraea saccharalis (Lepidoptera: Crambidae). A cana-de-açúcar é de grande importância para a 
agricultura brasileira e para a economia geral de muitos países em desenvolvimento. Estas plantas são atacadas por $D$. saccharalis, a mais importante praga desta cultura, causando significativas perdas econômicas. Como é sabido, as plantas desenvolveram complexas estratégias para se protegerem do ataque de insetos-praga. As variedades SP80-3280 (susceptível) e SP81-3250 (tolerante) de cana-de-açúcar foram expostas à $D$. saccharalis. Plantas submetidas à lagarta e plantas controle foram coletadas em 0.5, 6, 12 e 24 horas de experimento. As análises permitiram a identificação de genes diferencialmente expressos em resposta à lagarta nas duas variedades. Foram analisados o tempo, dinâmica e regulação da expressão de 3.840 clones do SUCEST, os quais foram crescidos na membrana de náilon por 6 horas. Estes ESTs foram agrupados em dezesseis classes: metabolismo de aminoácidos, crescimento/desenvolvimento, metabolismo de proteínas, metabolismo de RNA, metabolismo secundário, resposta à diferentes condições de estresse, transporte, bioenergética, transdução de sinal, dinâmica celular, metabolismo de DNA, metabolismo de lipídios, elementos móveis, metabolismo de nitrogênio, sulfato e fosfato, metabolismo de nucleotídeos e função não determinada (ND). Estes resultados ajudam elucidar as estratégias de defesa desenvolvidas pela cana-de-açúcar para evitar os danos causados por esta praga. Neste estudo, os dados do macroarray revelaram 580 ESTs com expressão aumentada, oriundos das duas variedades. Estes resultados são importantes não somente porque este é o primeiro estudo em larga-escala da expressão gênica de uma monocotiledônea em resposta ao ataque de herbívoros, mas também porque permite a comparação dos perfis de expressão entre genótipos susceptível e tolerante de cana-de-açúcar. Este estudo abre possibilidades para a engenharia genética de plantas de cana-de-açúcar insetoresistentes e também para o uso destes genes como marcadores moleculares em programas de melhoramento assistido. 


\title{
ANALYSIS OF EXPRESSED GENES INDUCED BY Diatraea saccharalis IN SUGARCANE USING BACTERIAL COLONIES ARRAYS
}

\author{
Author: CARLA FERNANDA BARSALOBRES \\ Adviser: Prof. Dr. MARCIO DE CASTRO SILVA FILHO
}

\section{SUMMARY}

Large-scale sequencing and the application of expressed sequence tag (EST) technology has led to the identification of hundreds of thousands of genomic sequences from various organisms. Through projects like the Sugarcane Expressed Sequence Tag (SUCEST), DNA arrays technology could be applied in monitoring gene expression. The first step of this work was to optimize the macroarray technique with bacterial colonies. Arrays were robotically constructed (Q-Bot). Bacterial cells carrying sugarcane cDNA clones were arrayed in duplicate onto nylon membrane and grown for 6 and 12 hours. As a result, we conclude that is possible to study the gene expression in largescale using macroarray through bacterial colony that grown for 6 hours. The second part of this work was to study how different two sugarcane varieties (Saccharum sp.) are in response resistance against Diatraea saccharalis (Lepidoptera: Crambidae). Sugarcane is of great importance for Brazilian's agriculture and for the general economy of many tropical developing countries. These plants are attacked by $D$. saccharalis, the most important insect pest of sugarcane, causing significant economic losses. As it is well known, plants have 
evolved complex defense strategies to protect them in opposition to attack by insects. The varieties SP80-3280 (susceptible) and SP81-3250 (tolerant) were exposed to $D$. saccharalis. Plants materials from plants with the borer and control plants (without the borer) were collected at 0.5, 6, 12 and 24 hours time points. The analysis revealed genes differentially expressed in response to sugarcane borer in both varieties. We analyzed the timing, dynamics, and regulation of the expression of 3,840 SUCEST clones, which were grown on a nylon membrane for $6 \mathrm{~h}$. These ESTs was grouped into 16 broad categories: amino-acid metabolism, plant grow and development, protein metabolism, RNA metabolism, secondary metabolism, stress response, transport, bioenergetics, signal transduction, cellular dynamics, DNA metabolism, lipid, fatty-acid metabolism, mobile genetic elements, nitrogen, sulphur and phosphate metabolism, nucleotide metabolism, and the group matched to unable to classify, which no indication of the function of the gene product are known. These results help to elucidate the defense strategies developed by sugarcane in order to prevent against insect damage. In this study, macroarray analyses revealed 580 ESTS with increased expression, from both varieties. These results are important not only because this is the first large-scale gene expression study of a monocot in response to insect attack, but also because it allows the comparison of the gene expression pattern between susceptible and tolerant genotypes. This study opens possibilities for genetically-engineering of insectresistant sugarcane and for using these genes as molecular markers in conventional breeding programs. 


\section{INTRODUÇÃo}

Desde as descobertas pioneiras de Mendel, os princípios de crescimento, desenvolvimento e respostas dos organismos ao ambiente têm sido estudados como programas determinados pela expressão dos genes. Assim, uma das questões mais relevantes seja entender como os elementos na seqüência de DNA são utilizados para a expressão de seus genes, em que condições cada produto gênico é sintetizado e, uma vez sintetizado, qual a sua função.

Vários projetos objetivando estudar o conjunto de genes de algumas espécies de gramíneas foram desenvolvidos, tais como o projeto de seqüências expressas (ESTs - Expressed Sequence Tags) do arroz (Oryza sativa L.) (Sasaki, 1998) e o do milho (Zea mays) (Gai et al., 2000). Também foram lançados diferentes programas para entender o mecanismo genético da cana-de-açúcar (Saccharum sp.). Estes projetos estão sendo conduzidos, por exemplo, na Austrália (Bureau of Sugar Experimental Stations - BSES), na África do Sul (South African Sugar Association Experiment Station - SASEX), nos Estados Unidos da América (American Society of Sugar Cane Technologists - ASSCT) e no Brasil (COPERSUCAR e FAPESP).

A agroindústria da cana-de-açúcar no Brasil tem uma produção anual de 300 milhões de toneladas, o que equivale a $25 \%$ do que é gerado no mundo. Metade desse volume vai para a produção de etanol (álcool) e a outra metade para a de açúcar. Além destes produtos, a cana-de-açúcar também constitui base para produção de matérias primas como bagaço, melaço, e outras de utilização crescente (Stupiello, 1987). 
No entanto, muitos fatores são responsáveis pela redução dos rendimentos agroindustriais da cultura, tais como a ação de pragas que causam significativas perdas por unidade de área. Entre essas pragas, destaca-se a broca do colmo (Diatraea saccharalis Fabricius, 1794), pela sua ampla distribuição nos canaviais do Brasil e de outras localidades no continente americano de maneira geral (Terán, 1987; Vendramim et al., 1989). A broca ataca a cultura da cana-de-açúcar pela abertura de galerias nos colmos, provocando perda de peso, morte das gemas e "coração morto", que além de reduzir a tonelagem por área, não raro, exige custosos replantes. Ocorrem também prejuízos indiretos consideráveis, pois as aberturas (orifícios e galerias) permitem a entrada dos fungos Colletotrichum falcatum Went e Fusarium moniliforme, que invertem a sacarose em glucose, diminuindo a pureza do caldo e o peso do açúcar (Guagliumi, 1972/73). Estima-se que para cada 1\% de intensidade de infestação perdem-se $0,14 \%$ de cana em peso no campo e 0,48\% de açúcar no processo de extração na indústria (Orlando-Filho et al., 1994).

Um crescente interesse por experimentos de expressão gênica tem sido verificado nas pesquisas médica, biológica e agrícola. Com o advento de projetos ESTs, como o SUCEST (Sugarcane EST Project), surgiram novas técnicas capazes de avaliar a expressão de milhares de genes simultaneamente. Dois exemplos dessas técnicas são os micro e macroarranjos de DNA, que permitem a obtenção de informações sobre a expressão de milhares de ESTS geradas nestes projetos. Nestas técnicas, o arranjo de diferentes formas de DNA permite o monitoramento simultâneo dos níveis de expressão em larga escala, possibilitando a análise de genes em diferentes tipos de células ou em diferentes condições fisiológicas. Isto é possível porque as variações nos níveis de transcritos celulares correspondem às diferenças na expressão gênica, que podem ser mensuradas por fluorescência em lâminas de vidro (Gasch et al., 2001) ou por radioisótopos em membranas de náilon (Jung \& Hwang, 2000). 
O desenvolvimento da tecnologia microarranjos de DNA está revolucionando os estudos de genômica funcional. A densidade de genes em arranjos de vidro pode atingir uma magnitude muito maior quando comparado à técnica de macroarranjos. Entretanto, esta metodologia é limitada, dado os altos custos destes ensaios. Para o estudo do diferencial de expressão gênica, através desta técnica, duas sondas são utilizadas (Cy3 e Cy5) para serem hibridizadas no arranjo, e para a detecção da intensidade de sinal é necessário um equipamento especial. Assim, a hibridização de microarranjos requer investimentos muito maiores que os necessários para arranjos em membranas de náilon. Além disso, é um consenso que a padronização dessa metodologia é muito mais complexa (Nadon \& Shoemaker, 2002).

Macroarranjos de DNA, em membranas de náilon, empregam metodologias rotineiras, robustas e de fácil implementação na maioria dos laboratórios de biologia molecular, sem a necessidade de investimentos vultosos e longos períodos de padronização. Aliado a isso, o uso de colônias bacterianas para o arranjo torna a técnica significativamente mais barata e uma alternativa para a análise da expressão gênica em larga escala (Cox, 2001).

Assim, através deste trabalho, procurou-se otimizar a técnica de macroarranjos de colônias bacterianas para estudos da expressão gênica em larga escala, devido à simplicidade na tecnologia quando comparado com microarranjos de DNA, e também analisar a expressão de 3.840 ESTs de canade-açúcar, com o objetivo de identificar e caracterizar genes expressos, como mecanismo de defesa, em duas variedades de cana-de-açúcar: SP80-3280 (susceptível à broca da cana) e SP81-3250 (tolerante à broca da cana). 


\section{REVISÃO DE LITERATURA}

\subsection{Projetos Para Obtenção de Seqüências Expressas (ESTs - Expressed Sequence Tags)}

Seqüências expressas (ESTs) são obtidas a partir do seqüenciamento do DNA complementar (CDNA) derivado da transcrição reversa do RNA mensageiro (mRNA) de um organismo, tecido ou ainda de um único tipo celular. São caracterizadas por serem seqüenciadas uma única vez (singlepass) e por este motivo, incompletas. Ou seja, geralmente são pequenas, com cerca de 600 pares de bases $(p b)$, e contêm seqüências parciais do mRNA de origem. Uma vez seqüenciadas as várias ESTs, torna-se possível a análise funcional dessa informação, não só para a identificação dos genes de interesse, mas também para conhecer o padrão de expressão gênica em diferentes condições ambientais.

Diversos organismos de interesse científico e/ou econômico têm sido investigados através de ESTs. Em tomate (Lycopersicon esculentum), organismo utilizado como modelo para diversos estudos relacionados à biologia das plantas, foram obtidas mais de 150.000 ESTs a partir de 26 bibliotecas de cDNA (Hoeven et al., 2002). Estas seqüências estão sendo utilizadas para a identificação de genes específicos a tecidos e fases do desenvolvimento, e também para identificar genes expressos em resposta aos estresses bióticos e abióticos. Uma vez identificadas, estas seqüências compreendem a base de dados de ESTS do tomate em The Institute for Genomic Research (TIGR, http://www.tigr.org/tdb/tgi//gi/). 
Com os mesmos objetivos, as empresas North Central Soybean Research e United Soybean Board subsidiaram o projeto de ESTS para a soja. O objetivo do programa foi gerar mais de 200.000 ESTs, representando genes expressos em diversos tecidos, órgãos e condições ambientais. Para esta espécie, aproximadamente 65 bibliotecas de cDNA foram criadas (Maguire et al., 2002).

Há também projetos de obtenção de ESTs para Arabidopsis, trigo, milho e arroz, entre outras plantas. O número de ESTs conhecido para estes organismos, segundo o banco de dados de ESTS do National Center for Biotecnology Information (NCBI, http://www.ncbi.nlm.nih.gov/dbEST/index.html), é de mais de 188.000 ESTs para Arabidopsis, 499.000 para trigo, 360.000 para milho e 260.000 para arroz.

Carson \& Botha (2000) realizaram uma análise preliminar de ESTS de cana-de-açúcar. Neste estudo, os autores apontaram informações úteis sobre as seqüências gênicas de cana-de-açúcar. Duzentos e cinqüenta clones, oriundos de folhas, foram selecionados aleatoriamente e seqüenciados na extremidade 5' do vetor. Destes clones, $24 \%$ foram tidos como novas seqüências gênicas. Estes resultados apresentaram uma aplicação bem sucedida da análise de ESTs e forneceram uma indicação da expressão de genes no tecido foliar.

No Brasil, a Fundação de Amparo à Pesquisa do Estado de São Paulo (FAPESP) e a Cooperativa dos Produtores de Cana, Açúcar e Álcool do Estado de São Paulo (COPERSUCAR), financiaram o projeto de obtenção de ESTS de cana-de-açúcar (SUCEST - Sugarcane EST Project). Neste projeto, 26 bibliotecas de cDNA foram construídas a partir da extração de RNA total de várias fontes: calos, raízes, diferentes estágios de folhas, colmos, plantas infectadas com patógenos, etc. (Vettore et al., 2001). Mais de 237.000 ESTs foram obtidas resultando em 43.141 clusters, que são agrupamentos das ESTs de acordo com o alinhamento das seqüências consenso (no sentido $5^{\prime} \rightarrow 3^{\prime}$ ) (Telles \& DaSilva, 2001). 
Ma et al. (2003) seqüênciaram a extremidade 5' de 9.216 clones de cana-de-açúcar, a partir de três bibliotecas de cDNA oriundas do ápice floral, folhas e internos maduros. Estas seqüências aumentaram o número de ESTS de cana-de-açúcar no GenBank em aproximadamente 8 vezes, a 8.985 de 992 (de acordo com dados de 8 junho 2003), sendo que as ESTs prévias foram oriundas dos trabalhos de Carson \& Botha (2000), Carson \& Botha (2002) e Carson et al. (2002). Estas ESTs foram comparadas com a base de dados de dados do SUCEST (http://sucest.lad.ic.unicamp.br/en/) e um total de 302 seqüências eram ausentes neste banco, sugerindo, de acordo com os autores, que estas diferenças podem ser devidas à fatores ambientais.

A partir da publicação do trabalho de Vettore et al. (2003) a base de dados do SUCEST foi adicionada ao GenBank, aumentando o número de ESTs descritas de cana-de-açúcar a 246.301.

\subsection{Análise em Larga Escala da Expressão Gênica}

A obtenção de ESTs é um meio rápido e efetivo de produzir seqüências parciais para a maioria dos genes expressos (Nogueira et al., 2003). A comparação de uma seqüência desconhecida com o vasto número de ESTs é um instrumento importante e poderoso da pesquisa genética (Ohlrogge \& Benning, 2000), e bancos de dados destas seqüências estão sendo utilizados na montagem de ferramentas para a análise em larga escala da expressão gênica (Cushman \& Bohnert, 2000).

Segundo Perret et al. (1998), a concentração do mRNA de um determinado gene em relação à concentração total de mRNA da célula é um indicativo do quanto este gene está sendo expresso, isto é, do quanto a célula está investindo em seu maquinário bioquímico para produzir a proteína codificada por este gene. Assim, foram desenvolvidas metodologias para medir a concentração relativa de determinados transcritos. Differential Display (Liang \& Pardee, 1992; Wan et al., 1996), Serial Analysis of Gene Expression - SAGE 
(Velculescu et al., 1995), biblioteca subtrativa (Sargent, 1987; Nedevi et al., 1993; Diatchenko et al., 1996; Xiong et al., 2001), Dot Blots (Stohl \& Lambowitz, 1983) e RT-PCR (Watakabe et al., 2001) são alguns dos métodos utilizados para monitorar mudanças na expressão gênica.

A partir de projetos ESTs, que produziram uma gigantesca quantidade de seqüências expressas, surgiram novas técnicas capazes de avaliar os níveis relativos de mRNA de milhares de genes simultaneamente (Adams et al., 1991; Baldwin et al., 1999; Kozian \& Kirschbaum, 1999). Dois exemplos dessas técnicas são os micro e os macroarranjos de DNA (Khan et al., 1999; VanHal et al., 2000; Narusaka et al., 2003).

Os arranjos de DNA são constituídos de um suporte sólido (membranas de náilon ou placas de vidro) onde os DNAs-alvo (ESTs, produtos de PCR, plasmídeos ou ainda bactérias contendo plasmídeos) são depositados de maneira ordenada (Lennon \& Hehrach, 1991; Nguyen et al., 1995). Os arranjos são então expostos para hibridização com uma população de mRNA marcada com fluoróforos ou isótopos radioativos. O sinal produzido por um determinado mRNA é proporcional à sua concentração na população original (Perret et al., 1998).

Convém ressaltar que existem diversos termos empregados para descrever os arranjos de DNA. O termo microarranjos será utilizado para descrever arranjos em vidro tais como DNA arrays (Schummer et al., 1999), oligonucleotide arrays (Cohen et al., 2000), cDNA glass slides (Ichikawa et al., 2000; Kuhn et al., 2001) e microarrays (White et al., 1999; Tanaka et al., 2000; Li et al., 2001). Já o termo macroarranjos será utilizado para descrever arranjos em membranas de náilon como, por exemplo, high density membranes (Gress et al., 1992; Zhao et al., 1995; Eckmann et al., 2000), nylon arrays (Cox, 2001), cDNA macroarrays (Sasaki et al., 2001; Watakabe et al., 2001) e filter arrays (Nogueira et al., 2003).

Os arranjos de DNA (micro e macroarranjos) podem ser diferenciados por três características: o suporte sólido empregado, o método de 
detecção e o número de genes analisados. Quanto aos suportes, os microarranjos utilizam slides de vidro ou chips de silício, enquanto os macroarranjos utilizam membranas de náilon. A detecção dos sinais pode ser feita por meio de fluoróforos (Cy3 e Cy5) em microarranjos e por isótopos radioativos $\left({ }^{32} \mathrm{P}\right.$ ou $\left.{ }^{33} \mathrm{P}\right)$ em macroarranjos. Em relação ao número de genes representados no suporte, os microarranjos podem analisar até 20.000 genes, enquanto que os macroarranjos analisam até 5.000 (Schena et al., 1995; Lashkari et al., 1997; Kozian \& Kirschbaum, 1999).

Em macroarranjos, dependendo do número de clones a serem arranjados e da densidade desejada, a aplicação nas membranas pode ser realizada manualmente ou por robô automático (Piétu et al., 1996). A Figura 1 representa um esquema da confecção de membranas de alta densidade (macroarranjos) e do preparo de sondas para análise em larga escala de transcritos celulares (mRNA). Nessas aplicações, clones de cDNA (ou produtos PCR) são arranjados em membranas de náilon através de um robô automático. As sondas complexas de cDNA são preparadas a partir dos mRNAs (RNA poli $\mathrm{A}+$ ) ou do RNA total, submetidos à transcriptase reversa e marcação radioativa simultânea dos cDNAs resultantes (Bernard et al., 1996). A marcação radioativa é feita com ${ }^{33} \mathrm{P}$ preferencialmente, pois este radioisótopo permite maior resolução quando se trabalha com membranas de alta densidade (Passos et al., 2000). 


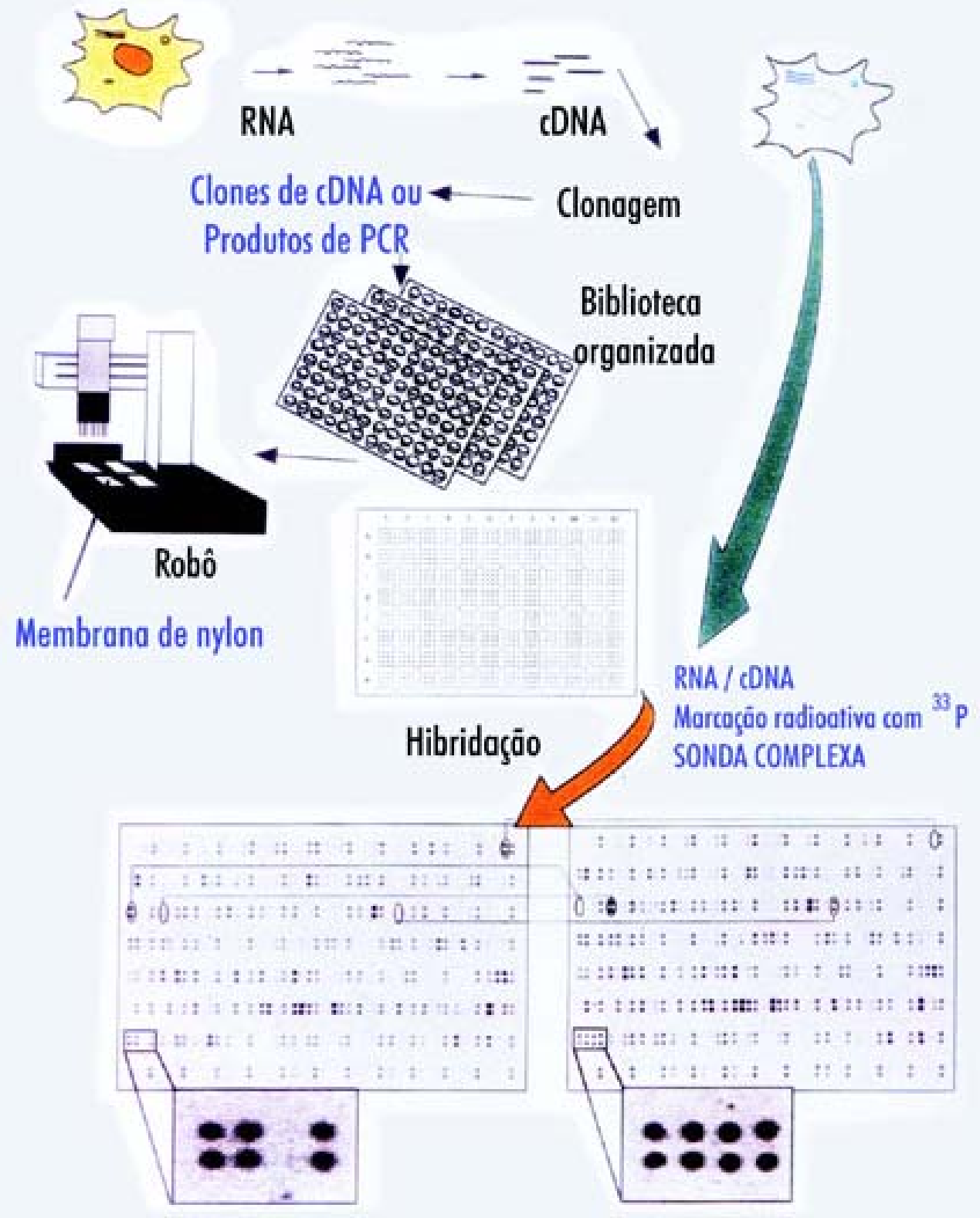

Figura 1 - Esquema da confecção de membranas de alta densidade (macroarranjos) e preparo de sondas para análise em larga escala de transcritos celulares (mRNA)

Fonte: adaptado de Passos et al. (2000) 
Tanto os micro como os macroarranjos de DNA baseiam-se no mesmo princípio: quanto maior a expressão de um determinado gene, em uma determinada condição (biológica ou ambiental), maior será o número de moléculas de mRNA referente àquele gene, sendo maior o número de cDNAs marcados na sonda sintetizada $\mathrm{e}$, conseqüentemente, maior o valor de intensidade de sinal detectado quando a sonda é hibridada com a seqüência específica de DNA (Felix et al., 2002).

O primeiro relato na literatura sobre o uso de microarranjos para análise da expressão gênica em larga escala foi o de Schena et al. (1995), que realizaram testes para padronizar a quantificação dos níveis de expressão gênica em Arabidopsis. Desde então, vários estudos foram feitos em plantas empregando-se essa metodologia.

Desprez et al. (1998) identificaram genes diferencialmente expressos em plântulas de Arabidopsis thaliana crescidas na ausência e na presença de luz. Eles estudaram 800 genes de Arabidopsis e através da comparação dos perfis de expressão obtidos encontraram variações significativas nos níveis de mRNA para aproximadamente $16 \%$ dos genes investigados.

As interações intra-específicas de feijão (Phaseolus vulgaris) em resposta ao ácaro Tetranicus urticae foram estudadas por Arimura et al. (2000a) utilizando a técnica de microarranjos. Os autores relataram neste trabalho a ativação diferencial de 324 genes dentre as 2.032 seqüências-alvo do arranjo.

Mudanças na expressão gênica em resposta a danos mecânicos e danos causados pela lagarta Pieris rapae em Arabidopsis foram relatadas por Reymond et al. (2000). O grupo mostrou que os perfis dos transcritos submetidos aos danos eram bem diferentes, sendo que somente um gene, o codificador da proteína tipo heveina (HEL), foi especificamente induzido pelo ataque da lagarta. 
Genes responsivos ao nitrato foram estudados em Arabidopsis por Wang R. et al. (2000). Analisando 5.524 genes arranjados em slides de vidro, foram encontrados 40 genes fortemente induzidos na presença de nitrato. Foi observado também um padrão de indução, no qual quanto maiores as concentrações de nitrato, maior o número de genes induzidos. Wang et al. (2001) também realizaram o monitoramento do perfil de expressão gênica em raízes de tomateiro (Lycopersicon esculentum). Neste trabalho foram utilizados 1.280 genes de tomate responsivos a diferentes tempos de exposição ao nitrato. Estes genes foram selecionados através de biblioteca subtrativa para a confecção das membranas de náilon. Foram encontrados 115 genes superexpressos para o excesso de exposição ao nitrato e também 14 genes que não são relacionados à nutrição vegetal.

A expressão de genes em resposta à deficiência de ferro foi analisada em raiz e parte aérea de Arabidopsis (Thimm et al., 2001). O perfil de expressão gênica foi investigado com o uso de 6.000 seqüências gênicas de Arabidopsis. Após 24 horas de exposição à deficiência de ferro foram identificados 227 genes induzidos e 219 genes reprimidos.

Com o objetivo de estudar a expressão de genes potencialmente regulados por ácido jasmônico, Sasaki et al. (2001) fizeram macroarranjos representando 2.880 genes de Arabidopsis thaliana. A análise dos resultados permitiu a identificação de 41 genes que respondem ao jasmonato.

Para identificar genes de defesa relacionados a patógenos em arroz (Oryza sativa), Xiong et al. (2001) arranjaram 288 colônias bacterianas em membranas de alta densidade. Eles identificaram 22 genes diferencialmente expressos em resposta à infecção pelo fungo Pyricularia grisea. A análise das seqüências indicou que a maioria destes genes são proteínas relacionadas a patógenos.

Seki et al. (2001) construíram bibliotecas de cDNAs utilizando mRNAs extraídos de plantas de Arabidopsis submetidas a diferente condições ambientais, tais como estresse hídrico e frio. As avaliações foram feitas em 
vários estágios de desenvolvimento da planta. Utilizando bibliotecas com seqüências expressas maiores (longESTs), aproximadamente 1.300 fragmentos de cDNAs foram amplificados por PCR e transferidos para slide de vidro. Como resultado, o grupo identificou 74 e 29 genes relacionados aos estresses hídrico e térmico respectivamente. Dos 103 genes identificados, 40 ainda não tinham sido reportados para estas condições.

Para identificar genes das plantas que respondem ao fotoperíodo, Schaffer et al. (2001) usaram microarranjos contendo 11.521 ESTs de Arabidopsis. Os autores coletaram amostras a cada 6 horas e determinaram que $11 \%$ dos genes eram induzidos ou reprimidos durante 0 dia e aproximadamente $2 \%$ estavam associados ao ritmo circadiano.

Carson et al. (2002) construíram bibliotecas subtrativas de colmos de cana-de-açúcar com baixo teor de sacarose e com maior teor, cujo resultado foram 400 seqüências de cDNA que estavam sendo diferencialmente expressas naquele experimento. Depois da clonagem destes fragmentos, os clones foram arranjados aleatoriamente em membranas de náilon e a análise dos resultados indicou que $36 \%$ e $30 \%$ do número total de ESTs analisadas eram diferencialmente expressas nos colmos com baixo e alto teor de sacarose respectivamente.

A resposta ao fungo Alternaria brassicicola em Arabidopsis foi estudada por Narusaka et al. (2003). O tipo selvagem de Arabidopsis thaliana (Columbia), resistente a $A$. brassicicola, foi contrastado com o mutante pad3, que não inibe o crescimento e desenvolvimento do patógeno. Microarranjos de 7.000 genes foram analisados e os resultados mostraram que o mutante pad3 não somente tem um padrão alterado de expressão gênica, mas também sincronismo de expressão de muitos genes relacionados à defesa em resposta ao fungo $A$. brassicicola.

Estudos de Halitschke et al. (2003) revelaram que plantas de tabaco (Nicotiana attenuata) atacadas pelo inseto Manduca sexta (Lepidoptera: Sphingidae) apresentam um perfil transcricional diferente de plantas não 
atacadas. Arranjos de 241 genes foram feitos em slide de vidro e mais de 68\% dos genes tiveram perfis de expressão diferenciados. Ainda sobre estas interações, Hui et al. (2003) fizeram microarranjos de 115 genes e a análise mostrou 73 genes diferencialmente expressos.

Usando um macroarranjo de 1.536 ESTS transferidas manualmente para membranas de náilon, Nogueira et al. (2003) analisaram a expressão gênica em plantas de cana-de-açúcar (Saccharum sp. cv SP803280) expostas ao frio. Foram encontrados 34 genes induzidos pelo frio, dos quais 20 ainda não tinham sido relatados. Além destes, 25 ESTs foram identificadas como sendo inibidas durante a exposição ao frio.

\subsection{Gênero Saccharum}

A cana-de-açúcar (Saccharum sp.) é uma gramínea perene pertencente ao gênero Saccharum, tribo Andropogoneae, família Poaceae (Gramineae). Das seis espécies de cana-de-açúcar conhecidas, duas são consideradas silvestres: S. robustum e S. spontaneum, e quatro cultivadas: $S$. officinarum, S. sinense, S. barberi e S. edule (Daniels \& Roach, 1987).

Originária do Sudeste Asiático, a cana-de-açúcar é hoje uma das mais importantes espécies vegetais em todo o mundo. É cultivada em cerca de 130 países tropicais e subtropicais, alcançando uma área total de 19 milhões de hectares (Agrianual, 2000).

Oficialmente, foi Martim Affonso de Souza que em 1532 trouxe a primeira muda de cana ao Brasil e iniciou seu cultivo na Capitania de São Vicente. Lá, ele próprio construiu o primeiro engenho de açúcar. Mas foi no Nordeste, principalmente nas Capitanias de Pernambuco e da Bahia, que os engenhos de açúcar se multiplicaram (Matsouka et al., 1999).

A industria sucro-alcooleira viveu um de seus maiores momentos quando o álcool passou a ser utilizado como combustível de automotivos, incentivado pelo Programa Nacional de Álcool - o Pró-Álcool - criado em 75/76 
(Fernandes, 1996). Hoje, o Brasil é responsável por 25\% da produção mundial de cana-de-açúcar, sendo o Estado de São Paulo produtor de $60 \%$ da produção nacional (Prossiga, 2002).

Apresentando um genoma complexo, o gênero Saccharum é caracterizado por um alto nível de ploidia, com número cromossômico variando de 40 a 140 e com conteúdo haplóide de DNA ao redor de 6 pg, equivalente a cerca de 7 - 8 vezes o genoma do arroz (Arumuganathan \& Earle, 1991). As variedades comerciais, via de regra, são aneuplóides resultantes do processo conhecido como "nobilização". Neste processo estão envolvidos cruzamentos interespecificos entre Saccharum officinarum e Saccharum spontaneum e uma série de retrocruzamentos para S. officinarum, a chamada "cana nobre" (DaSilva et al., 1993). As outras espécies do gênero Saccharum que cruzam com cana nobre, tais como S. sinense, S. barberi e S. edule, formam o chamado "complexo Saccharum" (Screenivasan et al., 1987).

Importantes variedades oriundas de programas de melhoramento de instituições como COPERSUCAR, o Instituto Agronômico de Campinas (IAC) e a Universidade de São Carlos (UFSCar) têm sido liberadas para cultivo. A COPERSUCAR trabalha com melhoramento genético de cana-de-açúcar desde 1969 e, até 1997, tinha desenvolvido cerca de 40 variedades. Desde que a lei dos cultivares entrou em vigor (LEI No 9.456, de 25 de abril de 1997), o programa de melhoramento desta cooperativa colocou no mercado mais de 17 variedades. Atualmente, $76 \%$ das usinas e destilarias associadas à COPERSUCAR e $50 \%$ das não-associadas de todo o país plantam as variedades liberadas por esta instituição (UDOP, 2001).

Os progressos no melhoramento genético da cana-de-açúcar, através de programas convencionais de cruzamentos, são limitados pelo elevado nível de ploidia, aliado à alta complexidade citogenética, e pela dificuldade de se realizar polinização controlada nestas plantas (Hogarth, 1987). Isso faz com que muitos materiais altamente promissores sejam abandonados por apresentarem falhas, como por exemplo, a suscetibilidade à alguma 
doença. Assim, estes fatores tornam a cana-de-açúcar uma excelente candidata ao melhoramento por meio da engenharia genética (Roach, 1995).

\subsection{Broca do colmo Diatraea saccharalis}

A cultura da cana-de-açúcar sofre o ataque de inúmeros insetospragas, os quais constituem-se muitas vezes em fatores limitantes à produção sucro-alcooleira. Estima-se que os danos causados pelos insetos na cultura ultrapassem os 550 milhões de dólares por ano (Bento, 1999). A broca da canade-açúcar (Diatraea saccharalis Fabricius, 1794), é a principal praga da cana, pertencendo à ordem Lepidoptera, família Crambidae, cuja provável origem foi nas Américas Central e do Sul (Sgrillo, 1979).

As lagartas de D. saccharalis, logo após a eclosão, alimentam-se do parênquima das folhas convergindo, a seguir, para a bainha das mesmas. Em seguida, as lagartas de primeira muda penetram nas gemas laterais e, a partir deste momento, abrem galerias dentro do colmo, onde completam o desenvolvimento larval (Vendramin, 1987).

De hábito noturno, as mariposas representam a fase adulta, e ovipositam geralmente na face abaxial das folhas de cana. O estágio larval é constituído de 5 a 6 ínstars, nos quais as lagartas se alimentam das folhas e do colmo da planta, como descrito acima. A fase pupal é aquela onde a lagarta se submete à transformação completa dentro de um casulo protetor, completando, assim, seu ciclo de vida (Gallo et al., 2002) A Figura 2 apresenta os diferentes estágios do ciclo de vida da broca da cana. 
A)

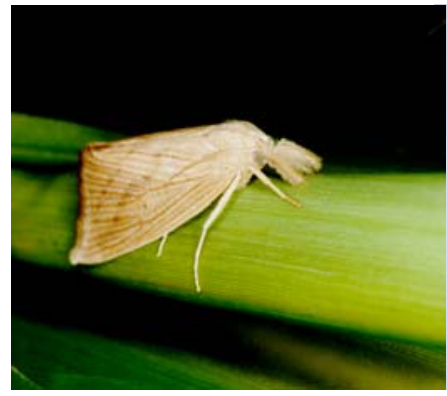

B)

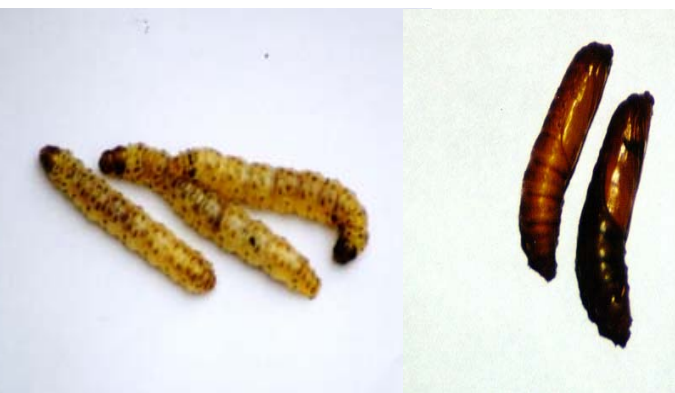

Figura 2 - Diferentes estágios do ciclo de vida do inseto $D$. saccharalis. (A) Indivíduo adulto (B) Estágio larval (C) Pupas do inseto Fonte: Centro de Tecnologia Copersucar

Plantas de cana-de-açúcar atacadas pela broca apresentam prejuízos diretos e indiretos. Os prejuízos diretos podem ser causados e observados em qualquer estágio do desenvolvimento da planta. Uma infestação no início da cultura (canas de até 4 meses de idade) pode danificar a região meristemática da planta (gema apical) causando o sintoma conhecido como "coração morto" (Figura 3), que é um dos responsáveis pelas falhas nos canaviais (Braga, 2001). Já em plantas adultas, os danos provocados causam brotações laterais, enraizamento aéreo, perda de peso, afinamento e quebra do colmo, atrofia de entrenós e morte da planta, o que leva a uma acentuada queda da produção (Parra, 1993). 


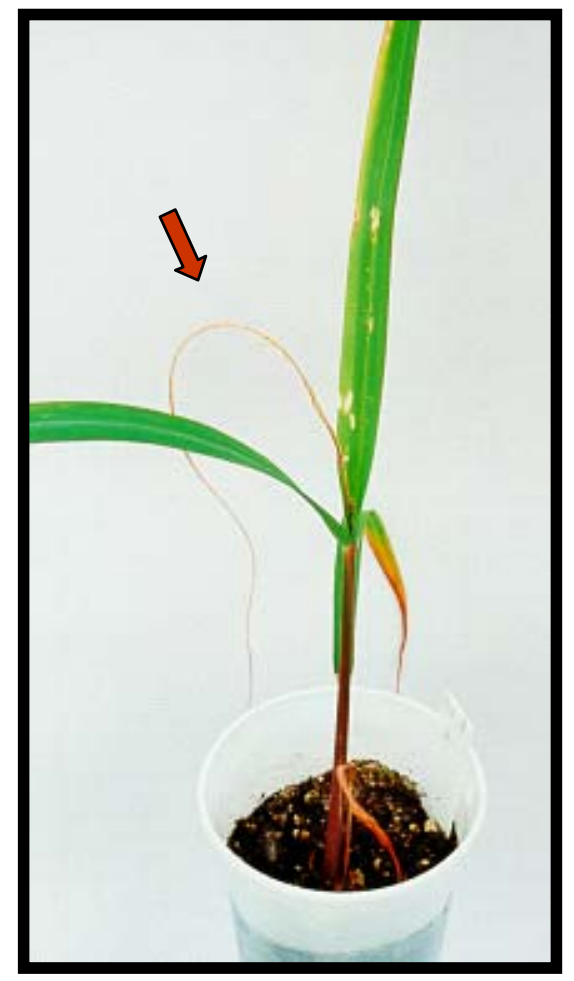

Figura 3 - Sintoma conhecido como "coração morto", indicado pela seta vermelha, causado pela broca da cana

Fonte: Centro de Tecnologia Copersucar

Os prejuízos indiretos são os mais importantes, pois através dos orifícios e galerias dos colmos causados pelas lagartas, penetram, entre outros, os fungos Glomerella tucumanensis e Colletotrichum falcatum, causadores da "podridão-vermelha" (Figura 4). As plantas invadidas por estes patógenos reagem produzindo substâncias de defesa a partir da conversão da sacarose. Isto resulta em perdas de até $50 \%$ do teor de sólidos solúveis por cento de caldo (BRIX), diminuindo também a pureza do caldo e dando menor rendimento em açúcar e álcool, sendo que os colmos mais atacados podem morrer (Mélo, 1984). 


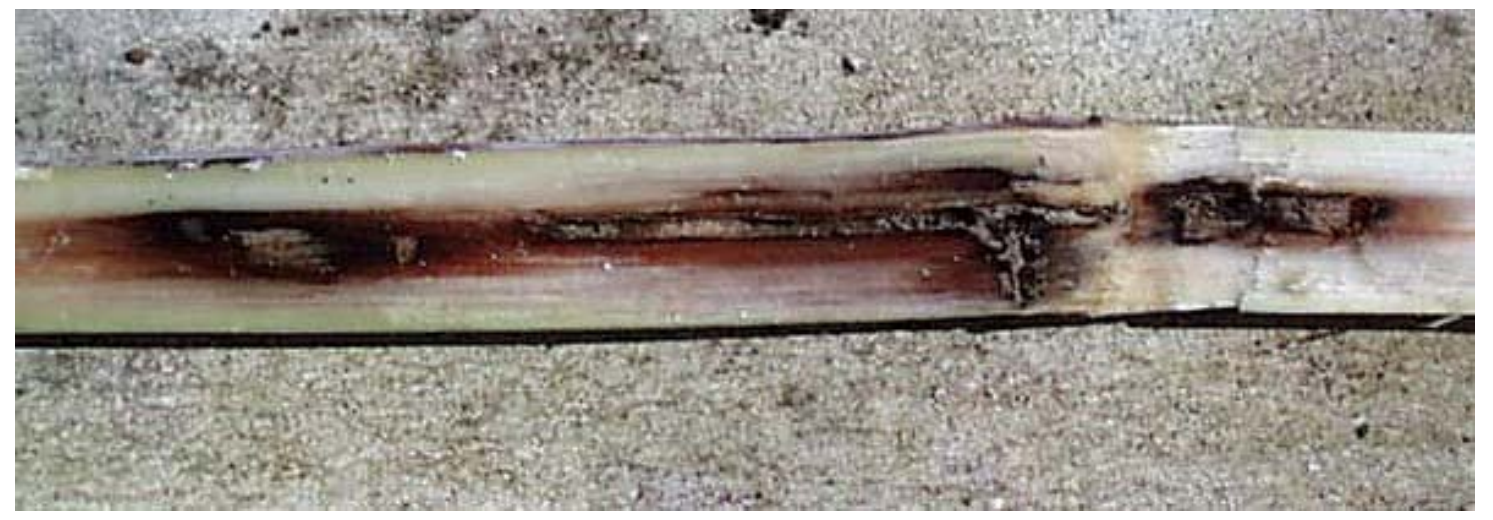

Figura 4 - Galerias do colmo, causado pela lagarta D. saccharalis, apresentando diferentes níveis da "podridão-vermelha"

Fonte: Centro de Tecnologia Copersucar

Ainda não é conhecido nenhum mecanismo de resistência em cana-de-açúcar contra a $D$. saccharalis, pois poucos estudos de resistência varietal da cana à broca têm sido desenvolvidos sob condições de infestação natural (Terán et al., 1985). Box (1952) constatou que numa intensidade de infestação de $12,5 \%$ houve redução de 5,8\% no teor de sacarose. Segundo Ingran \& Lugas, citados por Metcalfe (1969), para cada 1\% de entrenós perfurados ocorre uma queda de 0,5\% de açúcar. Experimentos em condições controladas com 20 variedades comerciais mostraram que houve uma redução de $0,18 \%$ em POL (sacarose aparente por cento de caldo), 0,25\% na produção de açúcar e 0,20\% na produção de álcool a cada 1\% de entrenós brocados (Centro de Tecnologia Copersucar, 1997). Estudos de transformação genética da cana com genes que codificam inibidores de proteases (P/s) ou a toxina Cry1Ab do Bacillus thuringiensis $(B t)$ mostraram resultados positivos no controle da lagarta (Falco \& Silva-Filho, 2003; Braga et al., 2003). 


\subsection{Mecanismos de Defesa das Plantas Contra Insetos Herbívoros}

Com o objetivo de diminuir o ataque dos insetos, as plantas desenvolveram diferentes mecanismos de defesa. Estes mecanismos envolvem complexas vias de sinalização, que incluem barreiras físicas e químicas (Falco et al., 2001; Mello \& Silva-Filho, 2002). Dentre estas defesas estão a indução de proteínas de defesa (Haruta et al., 2001), a liberação para o ambiente de compostos voláteis que atraem predadores dos insetos herbívoros (Birkett, 2000), a síntese de metabólitos secundários (Baldwin, 2001; Kliebenstein et al., 2001) e o aumento da densidade de tricomas em folhas e caules (Fordyce \& Agrawal, 2001). Em contrapartida, os insetos desenvolveram estratégias para superar tais barreiras impostas pelas plantas. Estas estratégias incluem a metabolização e seqüestro de compostos tóxicos (Scott \& Wen, 2001; Nishida, 2002), mecanismos de fuga (Zangerl, 1990) e alteração nos padrões de expressão gênica (Silva et al., 2001).

O manejo da resistência da cana-de-açúcar a insetos e patógenos é um dos principais objetivos no melhoramento desta cultura. Diversas variedades são impossibilitadas de alcançar o mercado devido à susceptibilidade a determinadas doenças e pragas. Assim, o estudo dos mecanismos de resistência destas plantas tem assumido um papel importante nas pesquisas atuais para o desenvolvimento da cultura (White, 1993; Yencho et al., 2000). Segundo Falco \& Silva-Filho (2001), a expressão de vários genes de defesa relatados na literatura contra herbívoros é também observada em cana-de-açúcar, sugerindo a existência de um mecanismo de defesa similar.

Uma classe de substâncias que está intimamente relacionada à defesa das plantas é a dos inibidores de proteases (PIs) (Carlini \& Grossi-deSá, 2002; Broadway \& Duffey, 1986). Os níveis destes Pls em folhas são normalmente baixos podendo ser rapidamente induzidos a níveis elevados quando as plantas são atacadas por insetos ou quando sofrem danos mecânicos (Ryan, 1990; Broadway, 1996; Rakwal et al., 2001). Estes inibidores 
funcionam como substratos específicos das proteases digestivas dos insetos, formando um complexo estável no qual a proteólise é limitada e extremamente lenta (Tiffin \& Gaut, 2001). Em última instância, os Pls atuam causando uma deficiência em aminoácidos, afetando o crescimento e desenvolvimento dos insetos. Eventualmente podem levá-los a morte devido à inibição das proteases digestivas ou à produção maciça destas enzimas, que reduzem a digestibilidade dos aminoácidos essenciais (Duan et al., 1996; Jongsma \& Bolter, 1997; Pompermayer et al., 2001).

A polifenol oxidase $(P P O)$, uma outra classe de proteínas induzidas por insetos e dano mecânico em plantas, têm sido reportadas como proteínas antimetabólicas aos insetos. Possuem a propriedade de modificarem aminoácidos livres, reduzindo a assimilação e o valor nutritivo das proteínas (Mayer \& Harel, 1979; Felton et al.,1992, Sommer et al., 1994; Constabel et al., 1995; Constabel et al., 2000).

Embora poucos sejam os trabalhos sobre mecanismos de defesa em cana-de-açúcar, a resposta das plantas contra herbivoria ou ferimento tem sido extensamente estudada em culturas como Arabidopsis (Reymond \& Farmer, 1998; Glazebrook, 1999; Schenk et al., 2000), tomate (McGurl et al., 1992; Thaler et al., 1996; Howe et al., 1996; Stout et al., 1999; Fidantsef et al., 1999), batata (Bolter \& Jongsma, 1995; Dammann et al., 1997; Korth \& Dixon, 1997), tabaco (Wang J. et al., 2000; Hermsmeier et al., 2001; Schittko et al., 2001), pimenta (Jung \& Hwang, 2000; Moura \& Ryan, 2001; Kim et al., 2001) e arroz (Schweizer et al., 1997; Agrawal et al., 2000; Rakwal et al., 2001).

Em tomate foi mostrado que a calmodulina (Bergey \& Ryan, 1999) e a mitogen-activated protein kinases - MAP quinase (Stratmann \& Ryan, 1997) estão envolvidas na via de transdução de sinais que levam a expressão de genes codificadores das proteínas induzidas por ferimento. Embora a via de transdução de sinal não esteja completamente elucidada, muitos trabalhos mostram que a expressão de genes induzidos por ferimentos é regulada positivamente por ácido jasmônico (Farmer \& Ryan, 1990), sistemina (Pearce et 
al., 1991), etileno (O’Donnell et al., 1996) e ácido abscísico (Peña-Cortés et al., 1991).

Os octadecanóides, moléculas cíclicas com função de sinalização em plantas (Creelman \& Mullet, 1997; León \& Sáchez-Serrano, 1999), são derivados do ácido linolênico, o ácido graxo mais abundante nas folhas (Browse \& Somerville, 1991). Não são encontrados ácidos graxos livres em concentrações significantes em células saudáveis da planta, mas o aumento do ácido linolênico livre é observado em células tratadas com elicitores (Gundlach et al., 1992). Concordantemente, a produção de ferimentos em folhas de tomate ocasiona um aumento relativo dos níveis de ácido linolênico (Conconi et al., 1996). Adicionalmente, foi relatado que o ferimento de folhas, estresse osmótico ou toque induzem a uma elevação dos níveis de ácido jasmônico, seguida de uma alteração na expressão de genes (Wasternack \& Parthier, 1997).

O ácido jasmônico e também seu metil-éster derivado, o metiljasmonato, ocorrem naturalmente em muitas espécies de plantas (Sembdner \& Parthier, 1993) e sua biossíntese se utiliza da via octadecanóide (Vick \& Zimmerman, 1984). A função do ácido jasmônico, dentre outras, é inibir ou estimular o crescimento e o desenvolvimento da planta (Turner et al., 2002).

Em Nicotiana attenuata, a síntese de ácido jasmônico induzido por pragas ou por danos mecânicos é suficiente para estimular a produção da toxina nicotina nas raízes da planta (Baldwin, 1996).

Em Arabidopsis foi mostrado que muitos genes são ativados por ferimento mecânico ou por herbivoria. Segundo Farmer et al. (1998), a expressão da maioria destes genes pode ser induzida por tratamento com ácido jasmônico ou com seu precursor, o ácido oxofitodienóico. Estes compostos, membros da família jasmonato, são, essencialmente, reguladores in vivo da expressão de genes de defesa (Reymond \& Farmer, 1998).

Em tomate descobriu-se a sistemina, um peptídeo de 18 aminoácidos que é liberado em locais afetados por insetos ou ferimentos. A via de transdução de sinal que media a sinalização da sistemina envolve a 
liberação de ácido linolênico das membranas e subseqüentemente conversão para o ácido jasmônico (Ryan \& Pearce, 1998). De acordo com Ryan (2000), a sistemina é o primeiro polipeptídeo-hormônio, que regula a ativação de mais de 20 genes de defesa em resposta ao ferimento. Segundo Constabel et al. (1998), tomate e pimenta também apresentam pró-sistemina, o peptídeo precursor da sistemina.

Utilizando-se dos dados do projeto SUCEST, Falco et al. (2001) analisaram in silico genes expressos em cana-de-açúcar envolvidos no metabolismo secundário, concluindo que algumas das proteínas expressas poderiam estar agindo como barreiras defensivas ao ataque de insetos. Contudo, o gene que codifica a sistemina não foi encontrado em cana-deaçúcar, sugerindo que os mecanismos de resposta em plantas apresentem uma certa especificidade. Estas observações geram perguntas sobre quais sinais sistêmicos poderiam estar presentes em cana-de-açúcar.

Paradies et al. (1980) e Felix et al. (1991) relataram que danos mecânicos induzem à produção do etileno. Segundo O'Donnell et al. (1996), o etileno é requerido na regulação dos níveis endógenos de ácido jasmônico na planta, indicando que este regulador também atua no caminho de transdução de sinal em resposta ao ferimento. Botella et al. (1996), pré-tratando plantas de soja (Glycine max L.) com 2,5-norbornadieno (NBD), um inibidor de etileno, e depois submetendo-as a ferimento mecânico ou metil-jasmonato, encontraram a inibição de Pls. Com este resultado os autores mostraram que o etileno é um sinal requerido para ativar a expressão de IPs. Entretanto, em concentrações fisiológicas o etileno não induz à produção destes transcritos. Assim o grupo concluiu que o etileno é um agente potencializador do metil-jasmonato, funcionando sinergisticamente no mecanismo de defesa das plantas.

Vários trabalhos mostram que o ácido abscísico pode agir como um sinal inicial no mecanismo de defesa contra ferimentos em plantas de tomate e batata (Peña-Cortés et al., 1989; Herde et al., 1996; Wasternack et al., 1996). Segundo Peña-Cortés et al. (1996) e Wasternack \& Parthier (1997), o 
ácido abscísico é um componente chave na cascata de transdução do sinal que conduz à ativação dos genes de defesa. Entretanto, em 1974, Ryan relatou que o ácido abscísico era incapaz de induzir genes de defesa em plantas de tomate submetidas a cortes. Este resultado repetiu-se consistentemente quando plantas de tomate jovens ou adultas foram utilizadas (Schaller \& Ryan, 1995). Adicionalmente, relatou-se esse resultado em calos (Kernan \& Thornberg, 1989) e também em células de tabaco em suspensão (Rickauer et al., 1992), ambos tratados com ácido abscísico. Finalmente, Birkenmeier \& Ryan (1998) evidenciaram que o ácido abscísico não é um sinal que conduz à ativação de genes de defesa, mas está envolvido, provavelmente, na manutenção de um equilíbrio hídrico da planta, uma vez que as maiores concentrações do ácido abscísico nas folhas feridas eram detectadas perto do local da ferida, sugerindo que o ácido abscísico pode ter se acumulado por causa da desidratação.

Segundo Janzen et al. (1986), os sinais de defesa das plantas podem estar agindo sozinhos ou em conjunto, contribuindo para a resistência destas contra os insetos-pragas. De acordo com Baldwin \& Preston (1999), a indução de respostas de defesa em plantas é provavelmente ativada por sinais emitidos durante os primeiros estágios do ataque do herbívoro.

A Figura 5 mostra que os sinais de defesa podem ativar defesas diretas e indiretas de encontro ao ataque do herbívoro. Defesas diretas são toxinas, tais como nicotina ou curcubitacinas, e redutores de digestibilidade, como os Pls ou as PPO, que aumentam a resistência da planta ao ataque do herbívoro. As defesas indiretas aumentam a mortalidade dos insetos através de um nível trófico mais elevado, onde a emissão de mono-, sesqui- ou homoterpenos das plantas atacadas são liberados para aumentar a eficiência da caça dos herbívoros pelos seus inimigos naturais. 


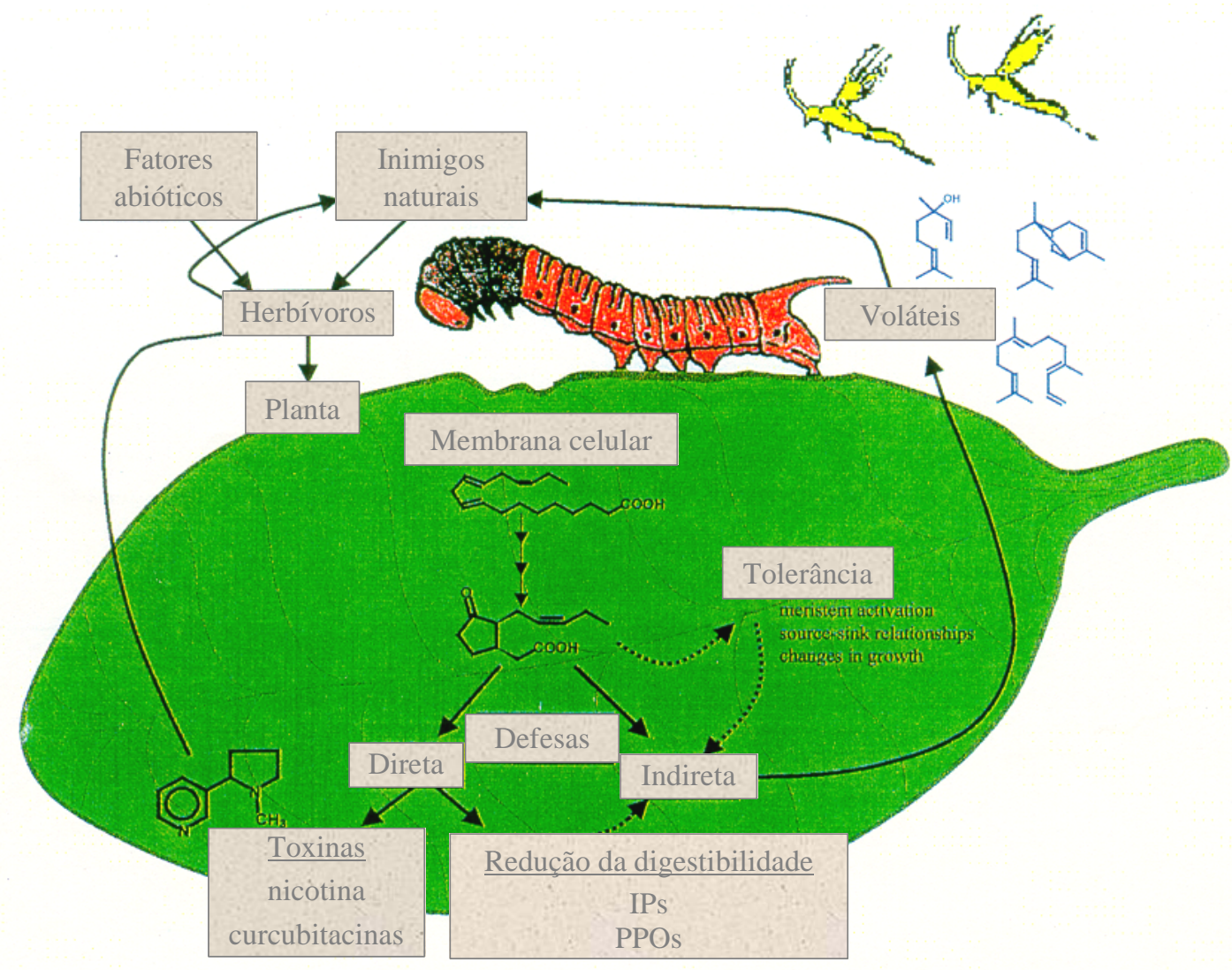

Figura 5 - Mecanismos de respostas de defesa em plantas contra herbívoros Fonte: adaptado de Baldwin \& Preston (1999)

$\mathrm{Na}$ maioria dos estudos de resposta a ferimentos, os danos mecânicos são usualmente feitos pelo esmagamento dos tecidos foliares. No entanto, há inúmeros estudos que indicam que a injúria das plantas por insetos resulta em respostas fisiológicas e bioquímicas diferentes daquelas produzidas por dano mecânico sozinho (Stratmann \& Ryan, 1997; Arimura et al., 2000b; Kessler \& Baldwin, 2001). Segundo Korth \& Dixon (1997), o tempo de acúmulo de transcritos de diversos genes induzidos por ferimento é diferente em folhas feridas por insetos e por dano mecânico. 
Buscando compostos que poderiam ser responsáveis pela ativação de genes específicos a um determinado inseto, Alborn et al. (1997) isolaram e identificaram o composto $\mathrm{N}$-(17-hydroxylinolenoyl)-L-glutamina, denominado volicitina, obtido pela extração da secreção oral de lagartas de Spodoptera exigua alimentadas com plântulas de milho.

Korth \& Dixon (1997) mostraram que quando se aplica o regurgitante isolado de lagartas de Manduca sexta ao local da folha de batata ferida mecanicamente, esta apresenta um acúmulo de transcritos idêntico àqueles acumulados em tecidos danificados pela lagarta. Aparentemente, um componente da saliva ou do conteúdo intestinal dos insetos pode agir como um elicitor da liberação de compostos voláteis, induzindo a resposta sistêmica da planta. Segundo os autores, a presença de um elicitor pode fornecer à planta um meio de reconhecimento do ataque de insetos pragas.

Estudos conduzidos por Turling e colaboradores (1990) mostraram que a liberação de componentes elicitores, que induzem a resposta sistêmica através de compostos voláteis, pode ser alcançada pelo tratamento do local ferido mecanicamente com regurgitante coletado de insetos fitófagos.

Paré \& Tumlinson (1997) mediram os níveis de compostos voláteis emitidos por plantas de algodão (Gossypium hirsutum L.) durante o ataque do inseto Spodoptera exigua. Eles observaram que estes compostos podem servir como um produto químico sinalizador, atraindo a atenção dos inimigos naturais do herbívoro à planta danificada. Análise de compostos voláteis das plantas danificadas artificialmente, com e sem secreção oral de lagartas, também foram realizadas. Os resultados mostraram que a aplicação da secreção oral também aumentou a produção e a liberação de diversos compostos voláteis, e sugerem que as plantas têm um papel ativo e dinâmico na medição da interação entre os herbívoros e seus inimigos naturais.

Reymond et al. (2000), comparando os resultados do ferimento mecânico com os danos causados pelo ataque da lagarta Pieris rapae em Arabidopsis, observaram que os perfis de transcritos eram bem diferentes, 
sendo que um gene foi especificamente induzido pelo ataque da lagarta, mas não pelo ferimento.

A alimentação pelo inseto Manduca sexta e a aplicação de secreções orais e regurgitantes destas lagartas, juntamente com feridas mecânicas, ativaram a liberação sistêmica de mono- e de sesquiterpenos, induzindo também a um aumento na produção de ácido jasmônico e a mudanças específicas na acumulação de seqüências expressas relacionadas ao crescimento e defesa da planta Nicotiana attenuata (Halitschke et al., 2001). Hermsmeier et al. (2001) forneceram a primeira caracterização em nível transcricional de um sistema modelo de interação planta-inseto, através do estudo entre tabaco (Nicotiana attenuata) e Manduca sexta. Eles utilizaram a técnica differential display e encontraram 27 transcritos diferencialmente expressos em plantas atacadas pelo inseto. Utilizando este mesmo sistema planta-inseto, Schittko et al. (2001) estudaram os transcritos diferencialmente expressos com a técnica northern blot. Ferimentos causados na presença da lagarta e ferimentos com adição de regurgitantes orais dos insetos foram avaliados. Estes autores encontraram 8 transcritos isolados de plantas atacadas pelo inseto e somente 2 diferenciais em presença da secreção oral. 


\section{MATERIAIS E MÉTODOS}

\subsection{Macroarranjos de Colônias Bacterianas}

\subsubsection{Seleção de Clones para a Confecção dos Macroarranjos}

Os macroarranjos foram construídos a partir da seleção de seqüências expressas (ESTS - Expressed Sequence Tags) obtidas no projeto de seqüenciamento de ESTS de cana-de-açúcar (SUCEST - Sugarcane EST Project; Vettore et al., 2001). Para este trabalho foram selecionados dois conjuntos de clones para a confecção das membranas. O primeiro constituiu-se de 4.608 ESTs de cana-de-açúcar oriundas da biblioteca RZ3, derivadas da zona de transição de folhas e raízes de plântulas de cana-de-açúcar. Estas seqüências foram tomadas ao acaso e utilizadas no experimento de determinação do tempo de crescimento bacteriano na membrana de náilon.

O segundo conjunto de clones foi utilizado para o estudo da expressão gênica de cana-de-açúcar em resposta a herbivoria pela Diatraea saccharalis e também para a análise comparativa entre duas variedades de cana. Neste conjunto foi utilizado um total de 3.840 ESTs sendo 384 homólogas a genes previamente relatados como envolvidos na resposta a estresses bióticos e abióticos, e 3.072 provenientes de bibliotecas de folha e colmo de cana-de-açúcar. Os genes relacionados à resposta a estresse biótico e abiótico foram oriundos de uma seleção feita por Fábio T. S. Nogueira e Vicente E. de Rosa Jr., ambos do Centro de Biologia Molecular e Engenharia Genética (CBMEG), UNICAMP, Campinas, SP (placa SCDG, Anexo A). As ESTs de 
folhas e colmos foram escolhidas em função do hábito alimentar da $D$. saccharalis, que se alimenta tanto de folhas quanto de colmos de cana-deaçúcar. Foram tomadas ao acaso 1.536 ESTs da biblioteca de folhas, placas SCUG065 (Anexo B), SCUG066 (Anexo C), SCUG067 (Anexo D) e SCUG068 (Anexo E); e 1.536 ESTs da biblioteca de colmo, placas SCUG107 (Anexo F), SCUG108 (Anexo G), SCUG109 (Anexo H) e SCUG110 (Anexo I). Como controle negativo, foram utilizadas colônias bacterianas (clone GFP) contendo o gene da proteína GFP (green-fluorescent protein) obtido da alga Aequorea victoria (Prasher et al., 1992). Por se tratar de uma proteína exclusiva deste organismo, esta seqüência não pode ser hibridizada com transcritos de plantas.

Para a seleção dos clones utilizados no segundo conjunto de membranas, ainda foi levado em consideração o tamanho de cada seqüência. Assim, as maiores seqüências expressas (IongESTs) foram utilizadas. Estas longESTs estão armazenadas a $-80^{\circ} \mathrm{C}$ no Centro Brasileiro de Estocagem de Clones (CBEC), UNESP, Jaboticabal, SP.

\subsubsection{Confecção das Membranas}

\subsubsection{Transferência das Bactérias para a Membrana de Náilon}

Todas as membranas contendo arranjos de colônias bacterianas foram confeccionadas no CBEG. As colônias bacterianas utilizadas para a confecção destas membranas eram oriundas de placas GENETIX com 384 clones (colônias) diferentes. Os clones eram dispostos em 24 colunas (1 a 24) e 16 linhas (de A a P). Cada clone, portanto, ocupa um lugar definido na placa.

A transferência das colônias bacterianas para as membranas de náilon foi feita pelo robô Q-Bot (GENETIX). A partir de um filtro de náilon de alta densidade (PerForma II - GENETIX) com dimensões $22,5 \times 22,5 \mathrm{~cm}^{2}$ foram construídas seis membranas idênticas, com dimensões $8 \times 12 \mathrm{~cm}^{2}$. Cada membrana é dividida em 384 quadrantes e corresponde a um campo do filtro 
(Figura 6). A posição do quadrante, por sua vez, indica a posição do clone em sua placa original. Desta forma, cada colônia bacteriana na membrana pode ser identificada quanto a sua posição de origem. Em cada quadrante (destaque em amarelo na Figura 6) foram depositados 20 (arranjo 5x4) ou 25 (arranjo 5x5) clones bacterianos.

Para determinação do tempo de crescimento bacteriano nas membranas de náilon foram feitos arranjos $5 \times 5$ dentro de cada quadrante da membrana. $O$ clone central deste arranjo, representado pela letra $G$ na Figura $7 \mathrm{~A}$, contém o gene codificador da proteína GFP (controle negativo). O tempo de transferência dos 4.608 clones em duplicata, das 13 placas GENETIX para as membranas, foi de 43 minutos.

O segundo conjunto de membranas, contendo 3.840 clones diferentes, foi transferido em 36 minutos. Em cada quadrante foram depositadas 2 cópias de 10 diferentes clones bacterianos, cada um proveniente de uma placa GENETIX, dispostos em um arranjo 5x4 (Figura 7B). A distribuição dos clones no arranjo $5 \times 4$ foi feita com objetivo de facilitar a visualização dos campos no filtro e foi estabelecida aleatoriamente. Cada número dentro do quadrante indica a placa de origem daquele clone. Assim, cada colônia bacteriana na membrana pode ser identificada quanto a sua placa (número dentro do quadrante) e posição de origem (quadrante dentro da membrana). A letra $\mathrm{G}$ representa o clone do controle negativo (GFP).

Para a transferência do material biológico às membranas, foram utilizadas placas GENETIX contendo 384 colônias bacterianas crescidas por 16-18 horas a $37^{\circ} \mathrm{C}$ (ORION, Estufa de Cultura 502, FAMEN - Controlador Modelo A-LT, São Paulo, Brasil) em meio líquido [4\% (p/v) de CG (Circle Grow Medium - BIO 101) suplementado com $1 \%(\mathrm{p} / \mathrm{v})$ de ampicilina (GIBCO-BRL) e $8 \%(\mathrm{v} / \mathrm{v})$ de glicerol (MERCK)]. 


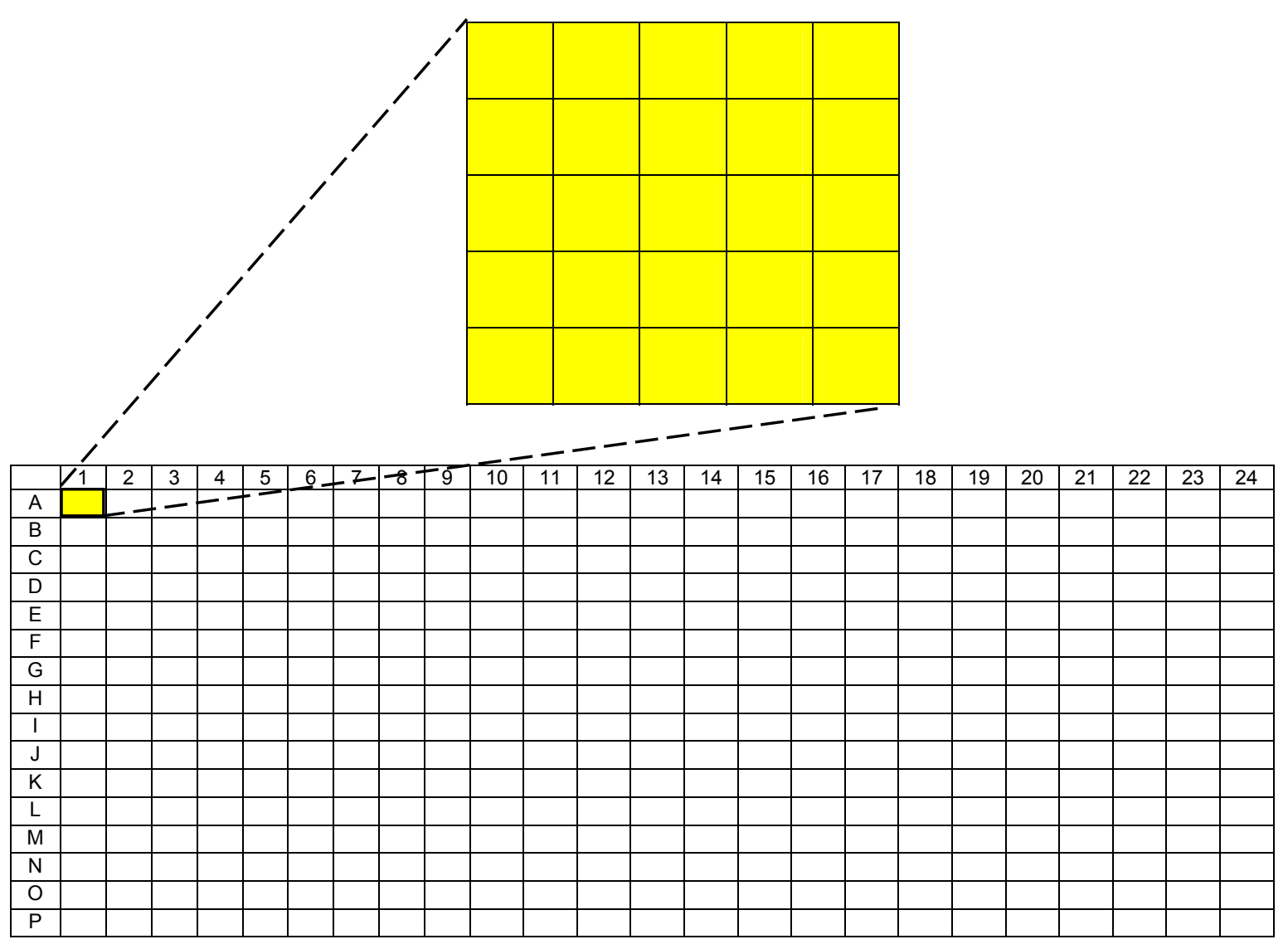

Figura 6 - Esquema da membrana utilizada para a construção dos macroarranjos. Cada quadrante, como o primeiro destacado em amarelo (posição A1), contém 20 ou 25 colônias bacterianas em arranjos $5 \times 4$ ou $5 \times 5$ respectivamente. Todas as colônias contidas neste quadrante são oriundas da posição $A 1$ de suas respectivas placas de origem 
A)

\begin{tabular}{|c|c|c|c|c|}
\hline 10 & 10 & 7 & 3 & 3 \\
\hline 11 & 9 & 7 & 4 & 2 \\
\hline 11 & 9 & $\mathrm{G}$ & 4 & 2 \\
\hline 12 & 8 & 6 & 5 & 1 \\
\hline 12 & 8 & 6 & 5 & 1 \\
\hline
\end{tabular}

B)

\begin{tabular}{|c|c|c|c|c|}
\hline 3 & 4 & 2 & 4 & $\mathrm{G}$ \\
\hline 5 & 9 & 6 & 10 & 9 \\
\hline 8 & 7 & 10 & $\mathrm{G}$ & 7 \\
\hline 6 & 2 & 5 & 8 & 3 \\
\hline & & & & \\
\hline
\end{tabular}

Figura 7 - Arranjos das colônias bacterianas em cada quadrante da membrana. Estes quadrantes possuem arranjos de $5 \times 5$ (A) ou $5 \times 4$ (B) colônias bacterianas. Os números representam a placa à qual aquele clone pertence

Previamente à transferência dos clones, filtros de náilon umedecidos em meio $4 \%(p / v)$ de CG suplementado com $0,5 \%(p / v)$ de ampicilina foram colocados sobre papel Whatman 3M também umedecidos neste meio. Bolhas de ar ou excesso de meio líquido no papel de filtro ou na membrana podem prejudicar o crescimento bacteriano na membrana, e portanto, foram evitados.

No processo de transferência, o robô imergiu sua cabeça de 384 pinos $(0,4 \mathrm{~mm}$ cada) por 3 segundos na placa contendo as colônias bacterianas e, em seguida, imprimiu na membrana, fazendo uma leve pressão por 10 milisegundos, depositando cerca de $20 \mathrm{nl}$ de solução contendo bactérias viáveis. De acordo com Bertucci et al. (1999) são transferidos de 20-60 ng de plasmídeos inseridos nas bactérias para a membrana de náilon. Cada clone foi impresso a uma distância de 900 microns em relação aos outros. Este processo foi repetido de acordo com o arranjo pré-determinado para os 6 campos do filtro 
de $22,5 \times 22,5 \mathrm{~cm}^{2}$. A seguir, a placa com as colônias bacterianas foi trocada, e a cabeça do robô foi lavada automaticamente em uma solução de água sanitária, seguida de lavagem em água Milli-Q, e por fim em etanol absoluto (SYNTH). Uma vez concluída a lavagem, os pinos foram secos com um jato de ar por 6 segundos. Após este processo de esterilização, o robô esperou mais 6 segundos para iniciar a transferência das colônias bacterianas da placa seguinte. O processo de limpeza e secagem foi repetido a cada troca de placa.

\subsubsection{Crescimento das Bactérias na Membrana}

Após a transferência das colônias bacterianas para o filtro de náilon, contendo as 6 membranas, este foi colocado em uma placa (QTray GENETIX) contendo meio CG semi-sólido [4\% (p/v) de CG, 4\% (p/v) de agar (SIGMA) e 1\% ( $\mathrm{p} / \mathrm{v})$ de ampicilina]. As membranas foram invertidas e incubadas à $37^{\circ} \mathrm{C}$ por 6 ou 12 horas (ORION, Estufa de Cultura 502, FAMEN Controlador Modelo A-LT, São Paulo, Brasil), para o crescimento das colônias bacterianas.

\subsubsection{Processamento da Membrana após o Crescimento das Bactérias}

Depois de 6 ou 12 horas a $37^{\circ} \mathrm{C}$, os filtros foram colocados sobre papel Whatman 3M umedecido em solução desnaturante [1,5 M NaCl (SYNTH) e $0,5 \mathrm{M} \mathrm{NaOH}$ (MALLINCKRODT)], onde permaneceram por 4 minutos em temperatura ambiente. A seguir, os filtros foram colocados sobre outro papel Whatman 3M umedecido em solução desnaturante, onde permaneceram por 4 minutos em uma placa de vidro dentro do banho-maria com água fervente. Após este procedimento, os filtros foram transferidos para outro papel Whatman $3 \mathrm{M}$ umedecido desta vez em solução neutralizante $[1,5 \mathrm{M} \mathrm{NaCl}, 1 \mathrm{M}$ Trizma (SIGMA) pH 7.0], onde foram deixados por 4 minutos. Posteriormente, os filtros foram colocados sobre papel Whatman $3 \mathrm{M}$ seco e ali deixados por 4 minutos. 
Transcorrido o tempo, os filtros foram transferidos para uma solução de proteinase $\mathrm{K}$ [ $5 \mathrm{M} \mathrm{NaCl}, 1 \mathrm{M}$ Tris (INVITROGEN) e HCl (SYNTH) pH 8.0, 0,5 M de ácido etileno diamino tetraacético - EDTA (MALLINCKRODT) pH 8.0, 10X Sarcosil (Sodium Lauryl Sarcosinate - SIGMA), 1,5\% (p/v) de Proteinase K (GIBCO-BRL)]. A proteinase $\mathrm{K}$ foi adicionada à solução momentos antes de seu uso. Assim, os filtros foram invertidos nesta solução, de modo que a face onde estavam as colônias ficasse totalmente submersa. Os filtros foram então incubados por 1 hora à $37^{\circ} \mathrm{C}$ em agitador orbital a 50 rpm (INNOVA 4230 Refrigerated Incubator Shaker, New Brunswick Scientific, Edison, NJ, EUA). Após a incubação, o excesso de solução foi retirado com o auxílio de um papel filtro em cada uma de suas faces. A seguir, fixou-se o material genético das bactérias nos filtros utilizando-se o aparelho Ultraviolet Crosslinker (CL-508), através de exposição a 120.000 microjoules por $\mathrm{cm}^{2}$ por 30 segundos.

\subsubsection{Normalização das Membranas}

\subsubsection{Hibridização com a Sonda Overgo}

Esta etapa foi realizada para selecionar os clones cujas duplicatas apresentavam quantidades similares de plasmídeo na membrana. Esta seleção foi feita com o auxílio de uma sonda chamada overgo.

Overgo é a denominação utilizada para a sonda correspondente a um fragmento de 36 pares de base do gene da $\beta$-lactamase. Bactérias transformadas com plasmídeos que codificam este gene são resistentes à ampicilina. As bibliotecas do SUCEST utilizadas na confecção das membranas de macroarranjo foram construídas com o plasmídeo pSPORT1 (GenBankU12390.1, Vettore et al., 2001). Este plasmídeo, de 4.110 pares de bases, contém o gene de resistência a ampicilina e os promotores SP6 e T7 flanqueando os cDNAs clonados. Uma vez que todas as bactérias utilizadas 
para a confecção das membranas continham o gene da resistência à ampicilina, o overgo pode ser utilizado para a normalização.

Na Figura 8 encontra-se a seqüência do fragmento do gene da $\beta$ lactamase no qual a sonda overgo marcada com o radioisótopo ${ }^{33} \mathrm{P}$ se liga às colônias bacterianas. Nesta região do gene, após a hibridização, um sinal radioativo é emitido de cada plasmídeo, permitindo que estes sejam quantificados em aparelho específico. Desta forma foi possível excluir os clones cuja quantidade de plasmídeo presente na membrana mostrou-se desigual.

Para síntese da sonda overgo foram utilizados oligonucleotídeos sintetizados pela empresa INVITROGEN (Figura 9), os quais foram diluídos a $100 \mu \mathrm{M}$ (Solução Estoque).

\section{5'...GTGGTCCTGCAACTTTATCCGCCTCCATCCAGTCTA...3'}

Figura 8 - Fragmento do gene da $\beta$-lactamase presente no plasmídeo pSPORT1 (GenBank-U12390.1). Este fragmento foi utilizado para a síntese de oligonucleotídeos que constituem a sonda overgo

Fonte: Invitrogem (2001) 
5' TAgACtgGatgGaggCGgAtAA 3'

não codante (243-222)

3' CGCCTATTTCAACGTCCTGGTG 5' codante (208-229)

Figura 9 - Seqüência dos oligonucleotídeos utilizados na síntese da sonda overgo. Os oligos sintetizados se ligam por complementaridade de bases no gene da $\beta$-lactamase contido no plasmídeo pSPORT1. Em amarelo está representada a região de overlap dos oligos

Para a reação de marcação da sonda overgo com $\alpha^{33} \mathrm{P}$-dCTP (AMERSHAM), utilizou-se uma solução com os dois oligonucleotídeos misturados a uma concentração final de $10 \mu \mathrm{M}$. Esta solução foi aquecida a $80^{\circ} \mathrm{C}$ por 5 minutos, em seguida, a $37^{\circ} \mathrm{C}$ por 10 minutos no termociclador (Programable Thermal Controller, PTC-100 ${ }^{\mathrm{TM}}$ ) e imediatamente armazenada no gelo. Após este procedimento, adicionou-se $5 \%(\mathrm{v} / \mathrm{v})$ de $0,2 \%(\mathrm{p} / \mathrm{v}) \mathrm{BSA}$ (SIGMA), 20\% (v/v) de solução OLB (APÊNDICE 1), 5\% de a ${ }^{33}$ P-dCTP (1

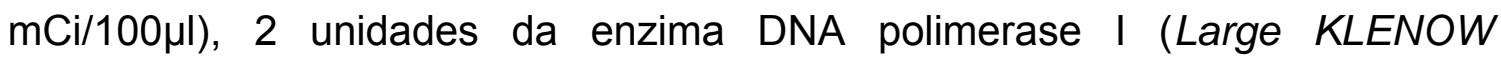
Fragment - INVITROGEN) e 50\% (v/v) de água Milli-Q autoclavada. Esta reação de marcação foi mantida em temperatura ambiente por uma hora. Após este período, o volume final foi ajustado para $50 \mu \mathrm{l}$ e a sonda foi purificada em coluna G-50 (AMERSHAM BIOSCIENCES), de acordo com as instruções do fabricante. Uma vez purificada, a sonda foi desnaturada à $90^{\circ} \mathrm{C}$ por 10 minutos em banho-seco (Multi-Block Heater, Lab-Line) e utilizada imediatamente.

Antes de iniciar a pré-hibridização, o filtro de náilon contendo as 6 membranas foi cortado. Em seguida as membranas foram lavadas com solução fervente de $0,5 \%(\mathrm{p} / \mathrm{v})$ de dodecil sulfato de sódio (SDS - BIOGRADE) por 5 minutos sob agitação, para diminuir o resíduo de fundo (background). 
Todas as membranas foram colocadas em um mesmo recipiente para serem lavadas, pré-hibridizadas e hibridizadas, sendo separadas uma da outra por uma malha de filtro.

A pré-hibridização foi realizada com uma solução de $1 \%(\mathrm{p} / \mathrm{v})$ de BSA, $0,2 \%(\mathrm{v} / \mathrm{v})$ de $0,5 \mathrm{M}$ de EDTA pH 8.0, 7\% (p/v) de SDS e $50 \%(\mathrm{v} / \mathrm{v})$ de $1 \mathrm{M}$ $\mathrm{Na}_{2} \mathrm{HPO}_{4}$ (MERCK). Esta solução foi aquecida no forno de microondas a $58^{\circ} \mathrm{C}$ e adicionada às membranas, que foram então incubadas no agitador orbital (TECNAL, TE 420) por 4 horas a 60 rpm. Após este período, esta solução foi descartada.

A solução de hibridização tem a mesma composição da solução de pré-hibridização adicionada da quantidade de sonda overgo relativa ao número de membranas. A sonda, previamente desnaturada a $90^{\circ} \mathrm{C}$ por 10 minutos, foi adicionada a esta solução aquecida no forno de microondas a $58^{\circ} \mathrm{C}$. As membranas foram incubadas nesta solução à $58^{\circ} \mathrm{C}$ por $18-20$ horas, no agitador orbital a $60 \mathrm{rpm}$ (TECNAL, TE 420).

Após a hibridização, as sondas foram descartadas em recipiente adequado para materiais radioativos e as membranas foram lavadas para que 0 excesso de sonda fosse removido. O processo envolveu duas lavagens com $2 \mathrm{X}$ SSC $[1,8 \%(p / v)$ de $\mathrm{NaCl}$ e $1,5 \%(p / v)$ de ácido cítrico (MALLINCKRODT)] e $0,1 \%(p / v)$ de SDS por 15 minutos a temperatura ambiente. A seguir, foram realizadas duas lavagens com $1,5 X$ SSC e $0,1 \%(p / v)$ de SDS por 15 minutos a $58^{\circ} \mathrm{C}$ (pré-aquecido). Por fim, as membranas foram lavadas duas vezes com $0,5 X$ SSC e $0,1 \%(p / v)$ de SDS por 15 minutos a $58^{\circ} \mathrm{C}$ (pré-aquecido).

Após as lavagens, o excesso de solução foi retirado e as membranas foram expostas por 72 horas em Imaging Plate (IP) (BAS-IP MS 2340, Fuji Photo Film Co., LTD, Japão). Depois da exposição das membranas marcadas com overgo, o IP foi revelado utilizando o aparelho FLA-3000G Image Analyzer (Fujifilm ${ }^{\mathrm{TM}}$ I\&I Imaging, Fujifilm Medical Systems, U.S.A., Inc.). Esta etapa do trabalho foi realizada no Centro de Biologia Molecular e Engenharia Genética (CBMEG), UNICAMP, Campinas, SP. 
Após a revelação do sinal, a sonda foi retirada das membranas com uma solução fervente de $0,1 \%(\mathrm{p} / \mathrm{v})$ de SDS por 15 minutos a $60 \mathrm{rpm}$ (TECNAL, TE 420) em temperatura ambiente. O processo foi repetido 2 vezes. As membranas foram expostas novamente em IP por mais 24 horas, para a verificação de que toda a sonda foi removida. Após esta nova revelação, como nenhum sinal foi detectado, as membranas foram guardadas a $-20^{\circ} \mathrm{C}$.

Depois de capturadas as imagens, estas foram analisadas no software Array Vision Evaluation 6.0 (Copyright (c) Imaging Reasearch Inc. 1995-2002) para a quantificação do sinal emitido pelo scanner. O valor dos sinais da leitura corrigido pelo resíduo de fundo ( $\mathrm{AARVOL}$ ), produzido por este programa, foi utilizado para a normalização das membranas. Estes sinais foram utilizados para minimizar as variações da técnica de preparo das membranas. Para análise dos dados utilizou-se o programa estatístico SAS versão 8.0 (Copyright (c) 1999-2001 by SAS Institute Inc., Cary, NC, USA).

\subsubsection{Análise dos Experimentos para Otimização da Técnica}

Para a avaliação de qual dos tempos de crescimento era mais apropriado para a confecção de macroarranjos de colônias bacterianas, testouse os períodos de incubação de 6 e 12 horas. Os valores obtidos pelo programa Array Vision Evaluation 6.0, para cada um dos experimentos, foram comparados por análise de variância, utilizando-se o programa estatístico SAS versão 8.0. Antes da análise, porém, foi necessário eliminar os clones cujo valor era igual a zero, os quais representam as colônias bacterianas que não cresceram sobre a membrana de náilon. Para que os dados pudessem obedecer a uma distribuição normal, foi necessário transformar os valores das leituras dos clones restantes de acordo com a fórmula: intensidade de sinal = log (valor da leitura + 1), para cada clone (APÊNDICE 2). A análise de variância de cada um dos experimentos foi realizada para verificar se havia diferenças 
entre repetições dos clones na mesma membrana e entre repetições dos clones em membranas diferentes.

O valor médio de resíduo de fundo também foi utilizado na análise dos experimentos para otimização da técnica. Estes valores foram obtidos de acordo com o programa Array Vision Evaluation 6.0.

\subsubsection{Contagem do Número de Unidades Formadoras de Colônias}

A contagem do número de unidades formadoras de colônias por $\mu \mathrm{l}$ (UFC/ $\mu$ l) foi realizada em meio CG semi-sólido, segundo protocolo adaptado de Milles \& Misra (1938). Esta contagem foi realizada para o clone do SUCEST SCCCAM1C08E06, o qual foi escolhido de forma aleatória. Este clone foi crescido em placa de Petri contendo meio CG semi-sólido por 16-18 horas a $37^{\circ} \mathrm{C}$. Após este período, uma colônia foi colocada em $100 \mu \mathrm{l}$ de meio CG líquido a $37^{\circ} \mathrm{C}$ por 6 ou 12 horas. A seguir, a suspensão bacteriana foi diluída em tampão fosfato-salino - PBS 10X pH 7.4 (100 mM Na $\mathrm{HPO}_{4}, 17 \mathrm{mM}$ $\mathrm{KH}_{2} \mathrm{PO}_{4}, 1,4 \mathrm{M} \mathrm{NaCl}, 27 \mathrm{mM} \mathrm{KCl}$ ) em tubos tipo Eppendorf de 0,2 ml sucessivamente de $10^{-1}$ a $10^{-7}$. As amostras foram homogeneizadas e aplicadas em 3 repetições de $2 \mu \mathrm{l}$ por quadrante em placas de meio CG semi-sólido e, em seguida, incubadas por 24 horas em estufa (Biologic Oxygen Demand - BOD, TECNAL, TE 390 ) à temperatura de $37^{\circ} \mathrm{C}$. A contagem foi efetuada na diluição onde as colônias apresentavam-se isoladas, entre o limite de 30 e 100 colônias. Os procedimentos que requereram ambiente estéril foram realizados em câmara de fluxo laminar vertical (VECO). Os experimentos foram realizados em triplicata. 


\subsubsection{Análise dos Experimentos para Normalização com a Sonda Overgo}

A seleção dos clones que apresentaram quantidades similares de plasmídeo na membrana também foi realizada utilizando-se o programa estatístico SAS. A partir dos valores de leitura transformados, obteve-se a variância de cada clone presente nas membranas de náilon (APÊNDICE 3). A seguir, os clones foram selecionados por homogeneidade de variância, ou seja, foi verificado se existem ou não diferenças significativas entre as variâncias das repetições dos clones analisados. Somente os clones com diferenças não significativas foram selecionados para análise da expressão gênica em canade-açúcar em resposta a herbivoria pela lagarta Diatraea saccharalis.

\subsection{Avaliação da Expressão Gênica em Resposta a Herbivoria}

\subsubsection{Material Vegetal: Cana-de-açúcar}

Foram utilizadas plantas de cana-de-açúcar das variedades comerciais SP80-3280 (Figura 10A) e SP81-3250 (Figura 10B), gentilmente cedidas pelo Dr. Eugênio César Ulian, Centro de Tecnologia Copersucar (CTC), Piracicaba, SP.

Nos testes de características agronômicas e tecnológicas para liberação de novas variedades, realizados pelo CTC, a variedade SP80-3280 é classificada como susceptível a Diatraea saccharalis. Nestes mesmos testes, a variedade SP81-3250 é classificada como tolerante a este inseto.

As plantas, obtidas através de propagação vegetativa de entrenós, cresceram em copos de plástico por 2 meses em estufa com cobertura de plástico, onde receberam os devidos tratos culturais. 


\subsubsection{Insetos: Diatraea Saccharalis}

Foram gentilmente cedidas pelo Dr. Enrico Arrigoni (Centro de Tecnologia Copersucar - CTC, Piracicaba, SP), lagartas de D. saccharalis com 10 dias de idade ( $2^{\circ}$ ínstar) para a montagem do experimento. As lagartas foram produzidas no CTC, e lá criadas até o sétimo dia de idade, em tubos de dieta (8 cm de diâmetro e $13 \mathrm{~cm}$ de altura) tampados com tela de inox, na proporção de 200 lagartas por tubo. Estas foram alimentadas com dieta artificial à base de farelo de soja e germe de trigo (King \& Hartley, 1985) e mantidas a $25^{\circ} \mathrm{C}, 60 \pm 10 \%$ de umidade e fotoperíodo de $14 / 10$ horas de claro/escuro. No sétimo dia, as lagartas, acondicionadas no frasco de dieta onde eclodiram e cresceram, foram recebidas, e então mantidas nas mesmas condições de fotoperíodo e temperatura em câmara climática (TECNAL, TE-400). 
A)

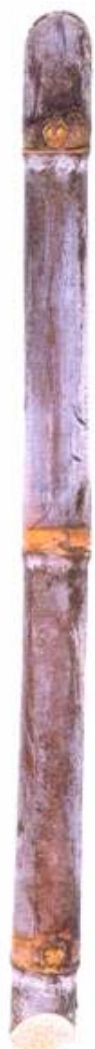

B)

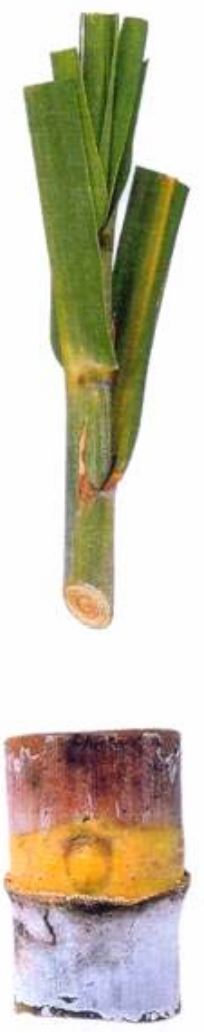

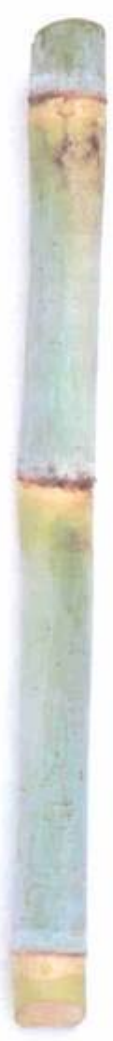
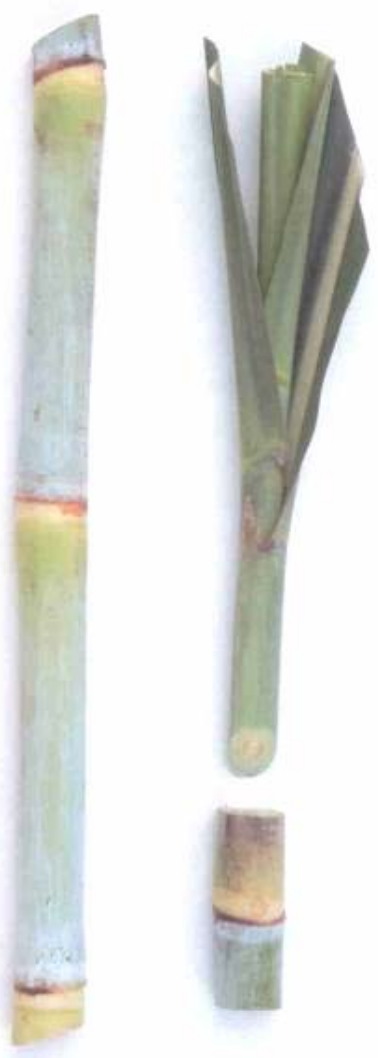

Figura 10 - Variedades comerciais Copersucar utilizadas nos experimentos para análise de genes diferencialmente expressos na presença da Diatraea saccharalis. (A) Variedade SP80-3280, susceptível à broca da cana (B) Variedade SP81-3250, tolerante à broca da cana

Foto cedida pelo Centro de Tecnologia Copersucar 


\subsubsection{Ensaio Biológico}

O experimento foi realizado no Laboratório de Biologia de Insetos, Departamento de Entomologia, ESALQ - USP, Piracicaba, SP. A montagem do ensaio biológico foi realizada em câmaras climáticas (FITOTRON - FAMEM Mod. 095E), com temperatura, luz e umidade relativa controladas $\left(28^{\circ} \mathrm{C}, 14 / 10\right.$ horas de claro/escuro e 70\% UR, respectivamente).

Foi realizado um estudo preliminar para determinar o número mínimo de lagartas de $D$. saccharalis a serem colocadas nas plantas de canade-açúcar, e o tempo para o início da herbivoria por estas lagartas. Neste estudo, observou-se que o tratamento com 2 lagartas mostrou-se ideal para um melhor monitoramento da herbivoria. Também foi possível observar que depois de 1 hora do início do experimento, já havia sinais de herbivoria pelas lagartas em todas as plantas, ou seja, folhas ou bainhas raspadas e presença de fezes (Figura 11A). Após 4 dias, as plantas apresentaram o sintoma de coração morto (Figura 11B).

Com base nos resultados obtidos no estudo preliminar, optou-se pela colocação de 2 lagartas de $2^{\circ}$ ínstar em cada planta, para a realização dos experimentos subseqüentes. Os tempos de coleta de tecido vegetal para posterior análise foram escolhidos de acordo com relatos da literatura (Ryan, 2000; Hui, 2003). Assim, os experimentos foram realizados colocando-se lagartas de $2^{\circ}$ ínstar de $D$. saccharalis em plantas de dois meses de idade de cana-de-açúcar e a coleta do material foi realizada nos tempos de 30 minutos, 6 horas, 12 horas e 24 horas após o início do experimento. 
B)
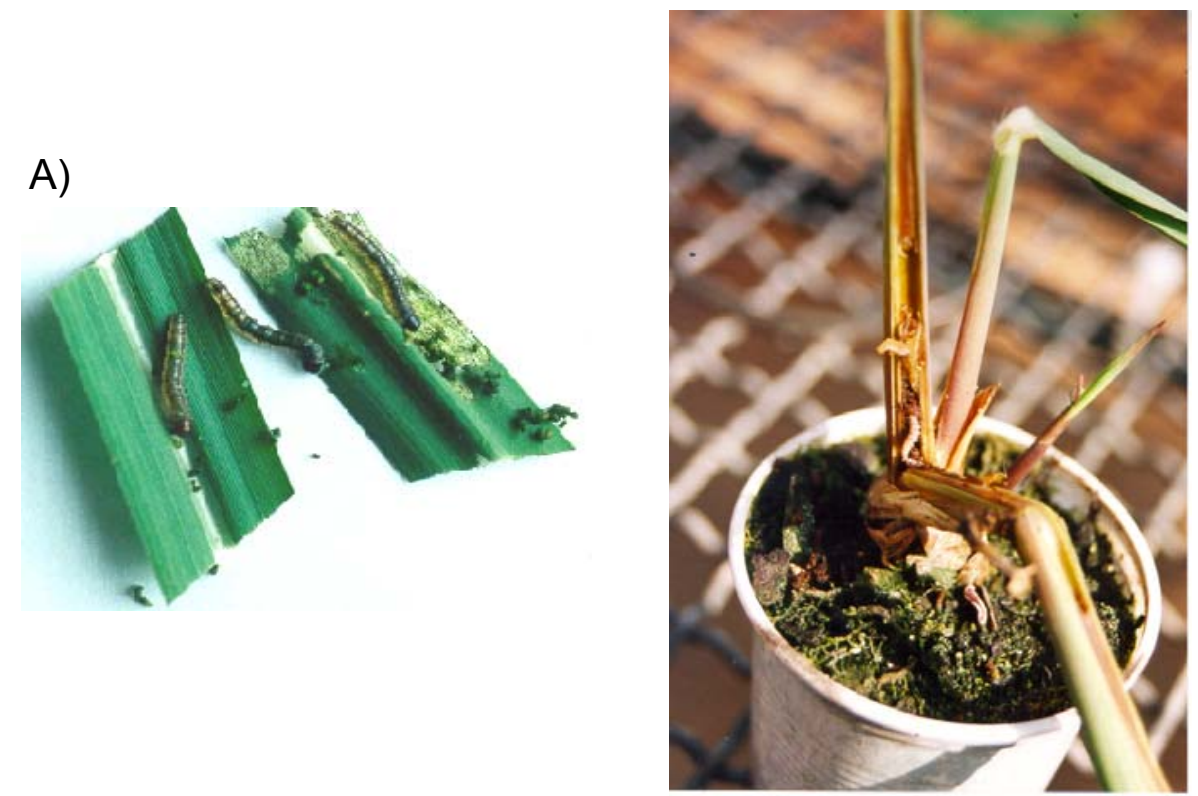

Figura 11 - Diferentes danos que a broca do colmo, Diatraea saccharalis, pode causar em cana-de-açúcar. (A) Raspagem das folhas (B) Galerias que culminam no coração morto e podridão vermelha

Uma semana antes da montagem do experimento, as plantas foram retiradas da estufa no CTC e levadas para o FITOTRON, onde foram aclimatadas. Foram utilizadas 16 plantas de cada variedade. Estas foram dispostas no FITOTRON em quatro prateleiras. Nas duas prateleiras superiores, dispuseram-se as plantas da variedade susceptível (SP80-3280), sendo que do lado direito ficaram as 8 plantas que receberiam as lagartas (tratamento $\mathrm{S}$ - susceptível), e do lado esquerdo, as 8 plantas controle (tratamento CS - controle susceptível). Nas duas prateleiras inferiores, dispuseram-se as plantas da variedade tolerante (SP81-3250), obedecendo-se ao mesmo esquema, do lado direito ficaram as 8 plantas que receberiam as 
lagartas (tratamento $\mathrm{T}$ - tolerante), e do lado esquerdo, as 8 plantas controle (tratamento CT - controle tolerante). Em cada prateleira as plantas foram numeradas aleatoriamente de 1 a 8 , e organizadas de modo que o espaço entre cada planta fosse de cerca de $20 \mathrm{~cm}$.

Dezoito horas antes da montagem do experimento, as lagartas foram retiradas do frasco de dieta e transferidas para um frasco vazio, onde permaneceram em jejum até a montagem do experimento. Durante todo o tempo, as plantas e lagartas foram mantidas em câmara climática, nas mesmas condições de temperatura, luz e umidade relativa do experimento.

O experimento foi iniciado às 7 horas da manhã, quando foram colocadas duas lagartas na face superior da folha mais nova totalmente aberta de cada planta não controle (Figura 12). Após 30 minutos, realizou-se o sorteio de dois números entre 1 e 8 , indicando assim as plantas que iriam ser coletadas neste tratamento (duas controle e duas com lagarta, por variedade). Este procedimento se repetiu para os tratamentos de 6, 12 e 24 horas após a montagem do experimento, conforme representado na Tabela 1.

Decorrido o tempo de cada tratamento, realizou-se a coleta do material vegetal. Toda a parte aérea de cada planta foi coletada e imediatamente congelada em nitrogênio líquido, sendo posteriormente armazenada a $-80^{\circ} \mathrm{C}$, até o momento de sua utilização para a extração do RNA total. 


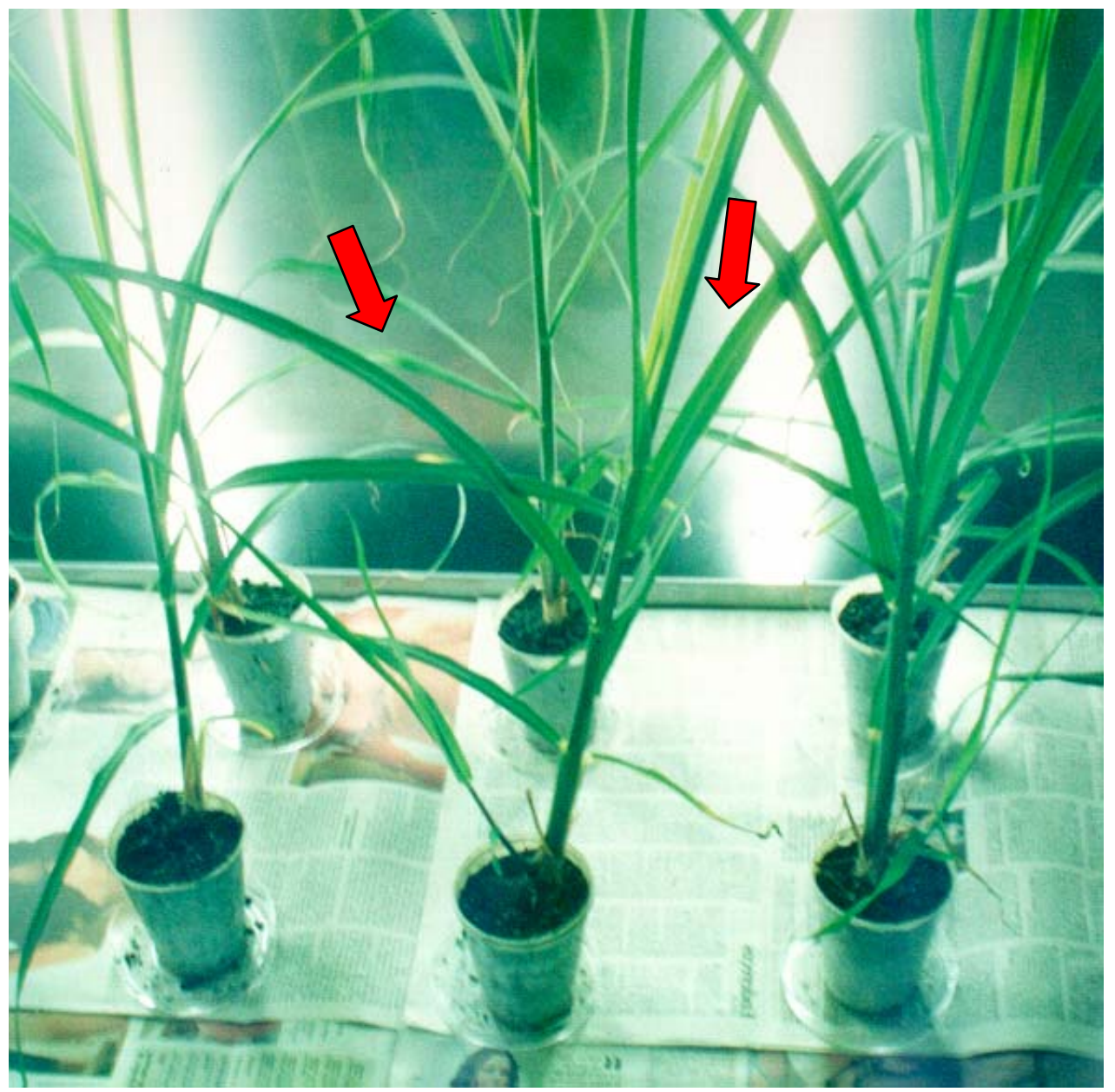

Figura 12 - As setas indicam o local onde as lagartas de Diatraea saccharalis foram colocadas na planta durante a montagem do experimento. Cada planta recebeu 2 lagartas de $2^{\circ}$ instar. As plantas de canade-açúcar estavam dispostas em prateleiras na câmara climática (FITOTRON) 
Tabela 1. Tratamentos aplicados nas variedades susceptível (SP80-3280) e tolerante (SP81-3250) de cana-de-açúcar submetidas a herbivoria pela lagarta $D$. saccharalis. Cada tratamento constituiu-se de duas plantas

\begin{tabular}{ccccc} 
& \multicolumn{2}{c}{ SUSCEPTÍVEL } & \multicolumn{2}{c}{ TOLERANTE } \\
\cline { 2 - 5 } & Lagartas & Controle & Lagartas & Controle \\
\hline 30 minutos & S0.5 & CS0.5 & T0.5 & CT0.5 \\
6 horas & S6 & CS6 & T6 & CT6 \\
12 horas & S12 & CS12 & T12 & CT12 \\
24 horas & S24 & CS24 & T24 & CT24 \\
\hline
\end{tabular}

\subsubsection{Extração de RNA Total}

Para a extração do RNA total foram utilizadas amostras de folhas de cana-de-açúcar coletadas no experimento. Cada amostra foi composta de $100 \mathrm{mg}$ de tecido oriundo da parte mediana da folha mais nova totalmente aberta, da qual foi excluída a nervura central. As amostras foram pesadas em balança analítica (METTLER TOLEDO, PB602) e então maceradas com bastão de vidro livre de RNAse em tubo tipo Eppendorf de 1,5 ml, em presença de nitrogênio líquido.

Imediatamente após a maceração, acrescentou-se no tubo $1 \mathrm{ml}$ de ácido guanidínico tiocianato-fenol-clorofórmio (TRIzol ${ }^{\circledR}, \mathrm{GIBCO}-\mathrm{BRL}$ ), e o tubo foi agitado intensamente até que o tecido macerado se homogeneizasse com o reagente. $O$ tubo foi então deixado à temperatura ambiente por 15 minutos, sendo gentilmente invertido, cerca de 10 vezes, a cada 5 minutos, para que se desse uma melhor homogeneização do material. Então esta solução foi centrifugada a $12.000 \times$ G (HETTICH ZENTRIFUGEN, MIKRO 22 R) por 15 minutos a $4^{\circ} \mathrm{C}$, e o sobrenadante foi transferido para um novo tubo tipo Eppendorf de 1,5 ml (cerca de $1 \mathrm{ml})$. 
A seguir, foi adicionado ao tubo $20 \%(\mathrm{v} / \mathrm{v})$ de clorofórmio puro (MERCK) e imediatamente agitou-se o tubo. Após este procedimento o tubo foi incubado por 3 minutos à temperatura ambiente, sendo, a seguir, centrifugado novamente a $12.000 \times \mathrm{G}$ por 15 minutos a $4^{\circ} \mathrm{C}$. Durante a centrifugação, a mistura separa-se em uma fase orgânica no fundo do tubo, uma interfase e uma fase aquosa, contendo o RNA, com volume de aproximadamente $60 \%$ do volume de TRIzol ${ }^{\circledR}$ utilizado na homogeneização.

Da fase aquosa, $600 \mu \mathrm{l}$ foram transferidos para novo tubo tipo Eppendorf de 1,5 ml, no qual realizou-se a precipitação do RNA. Para tal, adicionou-se $42 \%(\mathrm{v} / \mathrm{v})$ de isopropanol (MALLINCKRODT) e em seguida, a este volume total, foi adicionado $29 \%$ (v/v) de uma solução preparada com $0,8 \mathrm{M}$ de citrato de sódio (MALLINCKRODT) e 1,2 M de cloreto de sódio, em água tratada com 0,1\% (v/v) de dietil pirocarbonato (DEPC, SIGMA). As amostras foram homogeneizadas através de inversões suaves. Então, as amostras foram deixadas a temperatura ambiente por 10 minutos. Após este período de incubação, as amostras foram centrifugadas a $12.000 \times \mathrm{G}$ por 15 minutos a $4^{\circ} \mathrm{C}$. Ao fim deste processo, foi possível visualizar um pellet no fundo do tubo, e o sobrenadante foi descartado.

O pellet foi lavado uma vez com $1 \mathrm{ml}$ de etanol $75 \%(\mathrm{v} / \mathrm{v})$ [preparado com água tratada com $0,1 \%(\mathrm{v} / \mathrm{v})$ de DEPC] e a amostra resultante foi misturada no vortex (SCIENTIFIC INDUSTRIES, Model G-560) até que o pellet se destacasse da parede do tubo, e então,centrifugada a $7.500 \times \mathrm{G}$ por 5 minutos a $4^{\circ} \mathrm{C}$. O sobrenadante foi descartado novamente.

Após a lavagem, o pellet de RNA foi seco à temperatura ambiente por 10 minutos, com o tubo invertido sobre papel absorvente. Posteriormente, o pellet foi ressuspendido em $30 \mu \mathrm{l}$ de água livre de RNAse [tratada com $0,1 \%$ (v/v) de DEPC], sendo homogeneizado através da passagem da solução algumas vezes pela ponteira da pipeta, até que estivesse totalmente dissolvido. 
Após este processo as amostras foram incubadas por 10 minutos à $60^{\circ} \mathrm{C}$ e, em seguida, armazenadas a $-80^{\circ} \mathrm{C}$ até o momento do uso.

Para cada planta, realizou-se a extração de duas amostras separadamente. Como cada tratamento era composto de duas plantas, o RNA total de cada tratamento refere-se a quatro extrações independentes, cujo produto foi posteriormente homogeneizado em um único tubo tipo Eppendorf de $1,5 \mathrm{ml}$.

\subsubsection{Quantificação do RNA Total}

Antes do preparo do gel, a cuba de eletroforese (LIFE TECHNOLOGIES, HORIZON ${ }^{\circledR} 58$ ) foi tratada com solução $10 \%$ (v/v) de $\mathrm{H}_{2} \mathrm{O}_{2}$ preparada com água livre de RNAse por 15 minutos [tratada com 0,1\% (v/v) de DEPC] e lavada em água livre de RNAse.

A quantificação do RNA total de cada tratamento foi realizada em gel desnaturante composto de 0,01\% (p/v) de agarose (INVITROGEN), 1\% (v/v) de tampão MOPS 10X pH 7.0 [0,2 M de ácido 3-(N-morfolino)-propanossulfônico (MOPS - SIGMA), 50 mM de acetato de sódio (MALLINCKRODT) e 0,5 M de EDTA pH 8.0] e 0,05\% (v/v) de formaldeído 37\% (MALLINCKRODT), em água tratada com $0,1 \%(\mathrm{v} / \mathrm{v})$ de DEPC.

Durante o tempo de polimerização do gel, as amostras de RNA eram preparadas para a quantificação. Assim, $1 \mu \mathrm{l}$ de cada amostra de RNA foi colocado em $5 \mu$ de tampão desnaturante, e esta solução foi aquecida no termociclador a $60^{\circ} \mathrm{C}$ por 10 minutos, e imediatamente incubada em gelo para então ser aplicada no gel. O tampão desnaturante foi composto de $17,5 \%$ (v/v) de formaldeído 37\%, 10\% (v/v) de MOPS 10X, 50\% (v/v) de formamida deionizada $[2,5 \%(p / v)$ de resina de troca iônica mista (AG501-X8) em formamida (MALLINCKRODT)], 8\% (v/v) de brometo de etídio (BIOGRADE) 0,5\% (p/v), 4,5\% (v/v) de água tratada com 0,1\% (v/v) de DEPC e 10\% de tampão de amostra. Este tampão, por sua vez, foi previamente preparado de 
0,25\% (p/v) de azul de bromofenol (SIGMA), 0,25\% (p/v) de xileno cianol FF (SIGMA) e $40 \%$ (p/v) de sacarose (SYNTH), em água tratada com $0,1 \%(v / v)$ de DEPC, e armazenado a $-20^{\circ} \mathrm{C}$ até o momento do uso.

Após a aplicação das amostras no gel (6 $\mu \mathrm{l})$, adicionou-se tampão MOPS 1X na cuba até que o gel estivesse totalmente submerso. Todas as corridas eletroforéticas foram realizadas à $130 \mathrm{~V}$ por 30 minutos, utilizando LIFE TECHNOLOGIES, Model 250 como fonte de energia.

Após a eletroforese, o gel foi retirado da cuba, colocado sobre um transluminador UV (BI0-RAD, FLUOR-S ${ }^{\mathrm{TM}}$ MultImager), e fotodocumentado. A quantificação propriamente dita foi realizada através de comparação das bandas produzidas pelas amostras com bandas produzidas pelo RNA Ladder (0,24-9,5 Kb - INVITROGEN), que foi também colocado no gel. Cada $3 \mu$ deste marcador (1 RNA Ladder : 1 tampão desnaturante) equivale a 0,5 $\mu \mathrm{g}$ de RNA. Esta amostra recebeu o mesmo tratamento térmico que as amostras de RNA. Depois da quantificação, cerca de $30 \mu \mathrm{g}$ de RNA total de cada amostra foram liofilizados (HETO, FD4) e acondicionados em freezer $-20^{\circ} \mathrm{C}$ até o momento do preparo das sondas. O restante do RNA total foi armazenado a $-80^{\circ} \mathrm{C}$.

\subsubsection{Preparo das Sondas e Hibridização}

O preparo das sondas e a hibridização das membranas foram realizados no Centro de Tecnologia Copersucar (CTC), Piracicaba, SP, conforme metodologia adaptada descrita por Hervé et al. (1996).

Para o preparo das sondas, cerca de $30 \mu \mathrm{g}$ de RNA total liofilizado foram ressuspendidos em $10 \mu \mathrm{l}$ de água tratada com $0,1 \%(\mathrm{v} / \mathrm{v})$ de DEPC, e aquecidos a $60^{\circ} \mathrm{C}$ por 10 minutos no termociclador. Imediatamente após este procedimento, as amostras foram colocadas no gelo. Então, adicionou-se $3 \%$ ( $\mathrm{v} / \mathrm{v})$ de Oligo $\mathrm{dT}_{18} \mathrm{~V}(156 \mathrm{pmol}, 100 \mu \mathrm{M}$, INVITROGEN) e as amostras foram aquecidas novamente no termociclador a $75^{\circ} \mathrm{C}$ por 10 minutos, sendo em seguida incubadas no gelo. Adicionou-se então a cada amostra $10 \%(v / v)$ de 
First Strand Buffer (5X, GIBCO-BRL), 5\% (v/v) de ditiotreitol (DTT, $100 \mathrm{mM}$, GIBCO-BRL), $4 \% \quad(\mathrm{v} / \mathrm{v})$ de RNAguard ${ }^{\mathrm{TM}}$ RNAse Inhibitor (AMERSHAM BIOSCIENCES), 5\% (v/v) de dNTPs (10 mM cada) - exceto para dCTP (GIBCO-BRL), e $10 \%(\mathrm{v} / \mathrm{v})$ de $\alpha^{33} \mathrm{P}-\mathrm{dCTP}(10 \mathrm{mCi} / \mathrm{ml})$. Em seguida, as amostras foram aquecidas a $42^{\circ} \mathrm{C}$ por 5 minutos em heat-block. Posteriormente, foram adicionadas 260 unidades da enzima SuperScript ${ }^{\text {TM }}$ /I RNAse $H^{-}$Reverse Transcriptase (INVITROGEN) às amostras, seguida de uma leve agitação. As amostras foram incubadas à $42^{\circ} \mathrm{C}$ por 20 minutos (TECNAL, TE 420). Em seguida, foi adicionado 2,6\% (v/v) de dCTP (10 mM) e as amostras foram novamente incubadas à $42^{\circ} \mathrm{C}$ por 60 minutos. Após este período, foi adicionado $2 \%(\mathrm{v} / \mathrm{v})$ de polyadenylic acid Poly-A (AMERSHAM BIOSCIENCES), e esta solução foi desnaturada a $94^{\circ} \mathrm{C}$ por 5 minutos no banho-seco (Multi-Block Heater, Lab-Line). A seguir, adicionou-se 2,8\% (v/v) de $5 \mathrm{M} \mathrm{NaOH}$ e incubou-se à $37^{\circ} \mathrm{C}$ por 15 minutos. Por fim, as amostras receberam $2,8 \%(\mathrm{v} / \mathrm{v})$ de $3,94 \mathrm{M}$ $\mathrm{HCl}$ e $14 \%(v / v)$ de $1 \mathrm{M}$ Tris- $\mathrm{HCl}$ pH 7.5. O volume final de reação foi de 44,9 $\mu$ l. Para a purificação da sonda, este volume foi ajustado para $50 \mu \mathrm{l}$ com água Milli$Q$ autoclavada. A purificação foi realizada em coluna G-50. Uma vez purificada, a sonda foi utilizada imediatamente.

\subsubsection{Hibridização dos Macroarranjos}

A hibridização foi feita em duas etapas, a pré-hibridização e a hibridização propriamente dita. Em ambas utilizaram-se garrafas de hibridização (WHEATON) de $20 \times 3,5 \mathrm{~cm}$ para cada membrana. Para a pré-hibridização utilizou-se uma solução de $25 \%(\mathrm{v} / \mathrm{v})$ de $2 \mathrm{X} \mathrm{SSC} \mathrm{pH} \mathrm{7.0,2 \%} \mathrm{(v/v)} \mathrm{de} 1$ M Tris$\mathrm{HCl} \mathrm{pH} \mathrm{7.5,50 \%} \mathrm{(v/v)} \mathrm{de} \mathrm{formamida} \mathrm{deionizada,} \mathrm{10 \%} \mathrm{(v/v)} \mathrm{de} \mathrm{Denhardt's}$ (100X, INVITROGEN), 10\% (p/v) de SDS, 2\% (v/v) de Água Milli-Q autoclavada e $1 \%(p / v)$ de esperma de salmão (AMERSHAM BIOSCIENCES) previamente desnaturado no termociclador a $94^{\circ} \mathrm{C}$ por 10 minutos. As membranas ficaram nesta solução por 2 horas a $42^{\circ} \mathrm{C}$. 
Neste ínterim, foi preparada a solução de hibridização, composta de $25 \%(\mathrm{v} / \mathrm{v})$ de $2 \mathrm{XSSC}$ pH 7.0, 2\% (v/v) de $1 \mathrm{M}$ Tris- $\mathrm{HCl} \mathrm{pH} 7.5,50 \%(\mathrm{v} / \mathrm{v}) \mathrm{de}$ formamida deionizada, $2 \%(\mathrm{v} / \mathrm{v})$ de Denhardt's, $10 \%(\mathrm{v} / \mathrm{v})$ de SDS, $10 \%(\mathrm{v} / \mathrm{v})$ de dextran sulphate (AMERSHAM BIOSCIENCES) $50 \%(\mathrm{p} / \mathrm{v})$ e $1 \%(\mathrm{p} / \mathrm{v})$ de esperma de salmão previamente desnaturado no termociclador a $94^{\circ} \mathrm{C}$ por 10 minutos. Esta solução foi pré-aquecida em forno de microondas e depois deixada em forno de hibridização a $42^{\circ} \mathrm{C}$. A esta solução foi adicionada a sonda obtida da cana-de-açúcar, que tinha sido previamente desnaturada no termociclador a $94^{\circ} \mathrm{C}$ por 3 minutos.

Após o descarte da solução de pré-hibridização, adicionou-se às membranas a solução de hibridização com a sonda. A hibridização foi realizada em um período de $18-20$ horas a $42^{\circ} \mathrm{C}$, no forno de hibridização.

Após a hibridização, as sondas foram descartadas em recipiente apropriado para material radioativo e as membranas foram lavadas, em um único recipiente, e expostas da mesma maneira descrita para a sonda overgo.

Após exposição, retirou-se a sonda das membranas utilizando-se uma solução de $0,4 \mathrm{~N} \mathrm{NaOH}$ e $0,1 \%$ ( $\mathrm{p} / \mathrm{v})$ de SDS, sendo incubada em agitador orbital a $60 \mathrm{rpm}$ por 15 minutos à $65^{\circ} \mathrm{C}$ (TECNAL, TE 420). Este processo foi repetido duas vezes. Em seguida, a solução foi substituída por outra contendo $0,2 \mathrm{~N}$ Tris-HCl pH 8.0, 0,1\% (p/v) de SDS e 0,1X SSC. Incubou-se de novo a 60 rpm por 15 minutos, porém em temperatura ambiente. Esse processo foi repetido duas vezes. Por fim, as membranas foram expostas novamente em IP por mais 24 horas. Após esta nova revelação, como nenhum sinal foi detectado, as membranas foram guardadas a $-20^{\circ} \mathrm{C}$. 


\subsubsection{Análise dos Dados de Expressão Gênica Responsiva a Herbivoria}

A intensidade de sinal de cada membrana foi captada pelo sistema de análise de imagens Image Reader FLA-3000, no Departamento de Ciências Básicas da Faculdade de Zootecnia e Engenharia de Alimentos, USP, Pirassununga, SP. Depois de capturadas, as imagens foram analisadas no software Array Vision Evaluation 6.0 para a quantificação dos valores de leitura emitidos pelo scanner. O valor da leitura corrigido pelo resíduo de fundo (nARVOL), produzido por este programa, foi utilizado para o estudo do diferencial de expressão gênica dentro e entre os tratamentos.

O estudo comparativo da expressão gênica em cana-de-açúcar (Saccharum sp.) induzida pela broca da cana (Diatraea saccharalis) foi realizado utilizando-se o programa estatístico SAS versão 8.0 e o programa Excel (Office 2002, Microsoft). Primeiramente foram eliminados os clones que apresentaram crescimento diferenciado entre suas duas cópias, dados obtidos através da normalização com a sonda overgo. Então os valores das leituras dos clones restantes foram transformados de acordo com a fórmula: intensidade de sinal $=\log ($ valor da leitura +1$)$, para cada clone (APÊNDICE 4). A partir destes valores transformados, obteve-se a variância de cada clone e os clones foram selecionados por homogeneidade de variância, como descrito no item 3.1.4.

Para a variedade susceptível, a razão entre os tratamentos com lagarta e os controles foi calculada utilizando-se a média dos valores de leitura dos clones selecionados na normalização com a sonda de cDNA. O mesmo procedimento foi adotado para a variedade tolerante. Utilizando o programa Excel, foi possível identificar os genes cujo log da razão entre valores de leitura dos tratamentos com lagarta eram 2 vezes maiores ou menores (induzidos ou reprimidos) que os valores de leitura obtidos nos tratamentos das plantas controle. 


\section{RESULTADOS E DISCUSSÃO}

\subsection{Otimização da Técnica de Macroarranjos de DNA a partir de Colônias Bacterianas}

\subsubsection{Determinação do Tempo de Crescimento das Bactérias em Membranas de Náilon}

Inicialmente foram avaliados dois tempos de crescimento bacteriano (6 ou 12 horas) para se determinar o mais indicado para a confecção de macroarranjos de DNA utilizando-se colônias bacterianas. Membranas contendo 4.608 clones em duplicata foram hibridizadas com a sonda overgo. As imagens destas membranas foram capturadas pelo sistema de análise de imagens FLA-3000G Image Analyzer. A Figura 13 mostra um quadrante das membranas onde colônias bacterianas cresceram por 6 horas (quadro à esquerda) e 12 horas (quadro à direita). No quadro central da Figura 13 está representado o arranjo $5 \times 5$ dos clones bacterianos usado neste experimento. Observou-se, através destas imagens, que os clones crescidos por 6 horas são mais uniformes e estão mais distantes uns dos outros quando comparados com os crescidos por 12 horas. Depois de capturadas, as imagens foram quantificadas e analisadas utilizando-se o programa Array Vision Evaluation versão 6.0 .

O processo de normalização foi realizado utilizando-se os valores de leitura transformados obtidos para cada um dos experimentos. De acordo com o item 3.1.3.2, foram selecionados para análise 3.954 clones $(85,8 \%$ do total) nas membranas onde as bactérias foram crescidas por 6 horas. Estes 
clones foram selecionados por apresentarem quantidades similares de plasmídeo em suas réplicas. Da mesma maneira, foram selecionados 4.017 clones $(87,2 \%)$ para colônias bacterianas crescidas por 12 horas. No entanto, colônias bacterianas crescidas por 12 horas sobrepunham-se umas as outras, elevando o resíduo de fundo. O valor médio do resíduo de fundo foi de 68 para bactérias crescidas por 6 horas e de 371 para as crescidas por 12 horas, confirmando o observado na Figura 13.

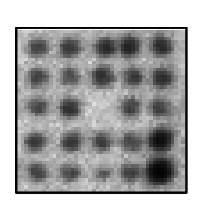

\begin{tabular}{|lllll|}
\hline 10 & 10 & 07 & 03 & 03 \\
11 & 09 & 07 & 04 & 02 \\
11 & 09 & 04 & 02 \\
12 & 08 & 06 & 05 & 01 \\
12 & 08 & 06 & 05 & 01 \\
\hline
\end{tabular}

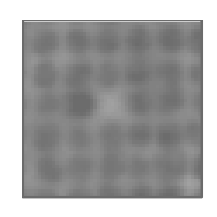

Figura 13 - Quadrante das membranas com arranjo 5x5 hibridizadas com a sonda overgo. À esquerda tem-se uma representação das colônias bacterianas crescidas por 6 horas na membrana de náilon. Do lado oposto estão as bactérias crescidas por 12 horas. Ao centro está o esquema do arranjo de colônias bacterianas utilizado na confecção destas membranas, onde números iguais correspondem ao mesmo clone

Através da normalização com a sonda overgo, realizou-se análise de variância para verificar a existência de diferenças entre repetições dos clones na mesma membrana, e entre repetições dos clones em diferentes membranas, de acordo com Gomes (2000). Foi encontrado que os valores de leitura transformados dos 3.954 clones crescidos por 6 horas na membrana de náilon são diferentes entre si (Pr<.0001) (Tabela 2). Isto significa que os clones 
apresentaram diferentes quantidades de plasmídeo entre si. Estas diferenças podem ser causadas devido aos diferentes produtos gênicos presentes nestes clones. De acordo com Baneyx (1999), indutores do promotor do operon lac podem estar presentes em células bacterianas e, se forem induzidos, podem produzir proteínas tóxicas à célula. Assim, a utilização das mesmas cepas de Escherichia coli e de vetores pSPORT1 para todas as colônias bacterianas não garante um crescimento uniforme para os diferentes clones. De acordo com a análise estatística apresentada na Tabela 2, nas membranas onde as bactérias cresceram por 6 horas não houve diferença significativa entre a quantidade de plasmídeo das repetições de um mesmo clone na mesma membrana [spot(memb)] e nem entre membranas (clones*memb). Estes dados indicam que o número de plasmídeos para um determinado clone é similar em todas as repetições e membranas, ou seja, não houve interação entre o crescimento bacteriano e o ambiente onde ele estava crescendo.

Tabela 2. Análise conjunta para colônias bacterianas crescidas por 6 horas sobre a membrana de náilon em arranjo $5 \times 5$

\begin{tabular}{lrrll}
\hline Causa de Variação & $\mathrm{GL}$ & $\mathrm{SQ}$ & $\mathrm{QM}$ & $\mathrm{Pr}>\mathrm{F}$ \\
\hline Memb & 1 & 1.935088 & 6.25 & 0.0124 \\
spot(memb) & 2 & 0.031380 & 0.10 & $0.9035^{* *}$ \\
clone & 3953 & 1.240875 & 4.01 & $<.0001^{*}$ \\
clone*memb $^{*}$ & 3953 & 0.199890 & 0.65 & $1.0000^{* *}$ \\
\hline
\end{tabular}

* valor significativo

** valor não significativo 
As colônias bacterianas crescidas por 12 horas também apresentaram diferenças entre diferentes clones dentro da mesma membrana (Tabela 3). No entanto, estes clones não apresentaram um comportamento similar entre as membranas (clone*memb $\Rightarrow \mathrm{Pr}<.0001$ ). Os dados da análise de variância descritos na Tabela 3 indicam que o crescimento bacteriano por 12 horas foi influenciado diferencialmente pelos recursos e espaço disponíveis. Nesta análise também foi possível observar que as diferenças entre repetições dos clones dentro da mesma membrana foram não significativas.

Devido à presença de um baixo valor de resíduo de fundo e da ausência de interação entre clone e membrana, o tempo de 6 horas de crescimento das bactérias nas membranas de alta densidade foi adotado para a confecção do segundo conjunto de macroarranjos. Estes resultados são contrários ao sugerido por Nizetic et al. (1991) e Hemberger et al. (2001), que recomendam um crescimento de 12 horas. Entretanto, acredita-se que esta variação seja dependente de cada experimento, não sendo possível extrapolar para todos os tipos de ensaios.

Tabela 3. Análise conjunta para colônias bacterianas crescidas por 12 horas sobre a membrana de náilon em arranjo $5 \times 5$

\begin{tabular}{lrrll}
\hline Causa de Variação & \multicolumn{1}{c}{$\mathrm{GL}$} & $\mathrm{SQ}$ & $\mathrm{QM}$ & $\mathrm{Pr}>\mathrm{F}$ \\
\hline memb & 1 & 0.2361289 & 2.90 & $0.0886{ }^{* *}$ \\
spot(memb) & 2 & 0.0128521 & 0.16 & $0.8540^{*}$ \\
clone & 4016 & 0.2326057 & 2.86 & $<.0001^{*}$ \\
clone*memb & 4016 & 0.1164171 & 1.43 & $<.0001{ }^{*}$ \\
\hline
\end{tabular}

* valor significativo

** valor não significativo 


\subsubsection{Contagem do Número de Unidades Formadoras de Colônias}

Com o objetivo de confirmar que o uso de macroarranjos com colônias bacterianas é melhor quando estas são crescidas por 6 horas, foi realizada a contagem do número de unidades formadoras de colônias por $\mu \mathrm{l}$ (UFC/ $\mu \mathrm{l})$.

Quando incubado à $37^{\circ} \mathrm{C}$ por 6 horas, o clone SCCCAM1C08E06 apresentou $6.835 \mathrm{UFC} / \mu \mathrm{l}$, e quando incubado à $37^{\circ} \mathrm{C}$ por 12 horas, o clone apresentou $9.835 \mathrm{UFC} / \mu \mathrm{l}$. Estes resultados, quando plotados na curva de crescimento padrão para bactérias $E$. coli, mostraram que com um número de bactérias viáveis da ordem de 6.000 a $7.000 \mathrm{UFC} / / \mu \mathrm{l}$ a cultura se encontra em fase exponencial de crescimento (Figura 14). De acordo com esta curva, o

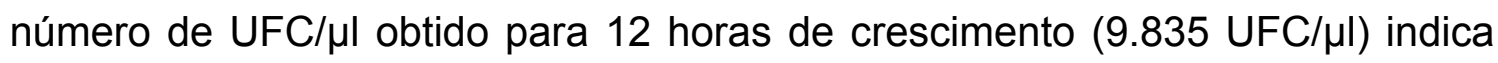
que a cultura já se encontra em fase estacionária (Figura 14). Estes resultados confirmam que a adoção do tempo de crescimento de 6 horas é o mais adequado para a confecção das membranas de alta densidade. 


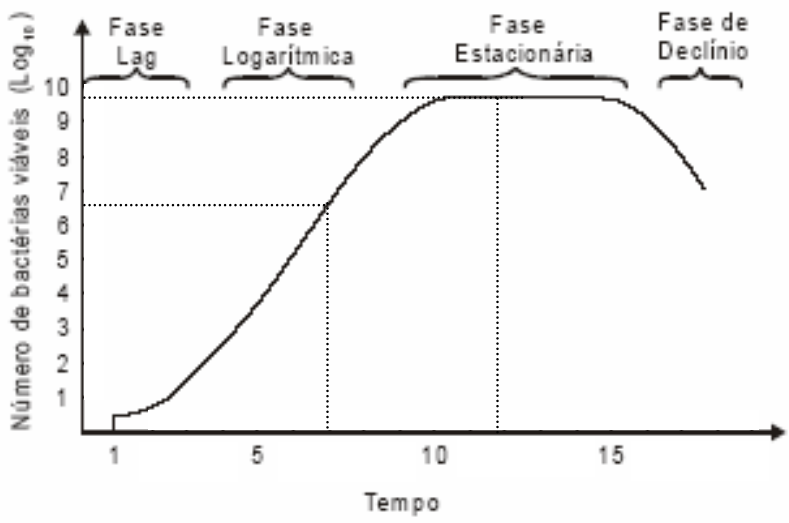

Figura 14 - Curva de crescimento padrão para Escherichia coli Fonte: adaptado de Alterthum \& Carvalhal (1999)

\subsection{Análise da Expressão Gênica em Resposta à Herbivoria}

\subsubsection{Normalização com a Sonda Overgo}

Para o estudo da expressão gênica de cana-de-açúcar em resposta a herbivoria pela Diatraea saccharalis e também para a análise comparativa entre as variedades susceptível e tolerante de cana, foi utilizado o segundo conjunto de clones apresentado no item 3.1.1, dispostos em um arranjo $5 \times 4$.

A seleção dos clones com quantidades similares de plasmídeo em suas repetições foi realizada utilizando-se a sonda overgo. Os clones foram selecionados por homogeneidade de variância, como descrito no item 3.1.4.

Primeiramente, foram eliminados 759 clones que não cresceram na membrana de náilon. Assim, os valores da intensidade de sinal correspondentes à 3.081 clones foram transformados e analisados pela homogeneidade de variância. Destes, 342 não tiveram homogeneidade entre as repetições, quer seja dentro da membrana ou entre as 6 membranas. Assim, 
foram selecionados 2.739 clones $(71,3 \%)$ com intensidade de sinal homogêneos em relação ao número de plasmídeos por clone nas 6 membranas réplicas, de acordo com a saída emitida pelo programa SAS (Figura 15).

\subsubsection{Normalização com as Sondas de cDNA de Cana-de-açúcar}

Os 2.739 clones selecionados na normalização com a sonda overgo foram também submetidos à análise de homogeneidade de variância quando hibridizados com as sondas oriundas do RNA extraído de cana-deaçúcar, conforme descrito no item 3.2.7. Estas sondas estão apresentadas na Tabela 4, onde se encontra o número de clones selecionados para cada tratamento a que as variedades susceptível (S - SP80-3280) e tolerante ( T SP81-3250) foram submetidas.

Pode ser observado na Tabela 4 que a sonda CS6 (oriunda de plantas controle $-C$, sem lagarta - da variedade susceptível $-S$ - submetidas ao tratamento de 6 horas) foi a que obteve o menor número de clones selecionados $(75,2 \%)$. Já a sonda com maior número de clones foi a CS0.5, com $99,3 \%$ de seus clones selecionados. 


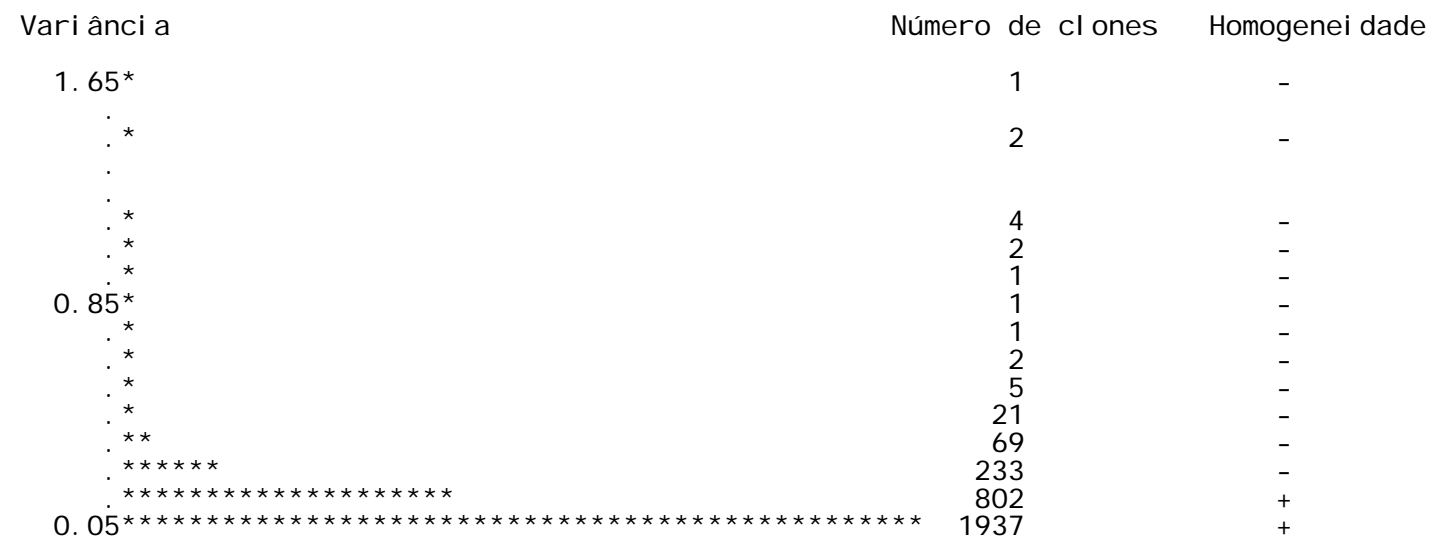

Figura 15 - Saída do programa SAS para a análise de normalização com a sonda overgo. Os números à esquerda são as variâncias dos valores de leitura transformados. No centro estão indicados quantos clones apresentaram tal variação. À direita encontra-se o resultado da análise de homogeneidade de variância, calculado diretamente pelo programa. $\left({ }^{*}\right)$ pode representar até 41 clones. (-) dados não homogêneos (+) representa homogeneidade

Para as sondas oriundas de plantas susceptíveis, 1.466 clones foram comuns aos 4 tratamentos submetidos à herbivoria (S0.5, S6, S12, S24) e 1.857 clones comuns aos 4 tratamentos controle (CS0.5, CS6, CS12, CS24). No total 1.007 clones estavam presentes nos 8 tratamentos. Em relação à análise das sondas provenientes das plantas da variedade tolerante, foi encontrado 1.358 clones comuns aos 8 tratamentos, sendo que para os 4 tratamentos submetidos à herbivoria (T0.5, T6, T12, T24) encontrou-se 1.791 clones em comum, e 2.079 comuns aos tratamentos controle (CT0.5, CT6, CT12, CT24). 
Tabela 4. Número de clones selecionados por homogeneidade de variância para cada sonda, a partir dos 2.739 selecionados no processo de normalização com a sonda overgo

\begin{tabular}{lc}
\hline SONDA $^{1 ; 2}$ & NÚMERO DE CLONES SELECIONADOS $^{3}$ \\
\hline S0.5 & $2.680(97,9 \%)$ \\
S6 & $2.080(75,9 \%)$ \\
S12 & $2.484(90,7 \%)$ \\
S24 & $2.093(76,4 \%)$ \\
CS0.5 & $2.719(99,3 \%)$ \\
CS6 & $2.060(75,2 \%)$ \\
CS12 & $2.579(94,2 \%)$ \\
CS24 & $2.538(92,7 \%)$ \\
T0.5 & $2.712(99,0 \%)$ \\
T6 & $2.149(78,5 \%)$ \\
T12 & $2.632(96,1 \%)$ \\
T24 & $2.293(83,7 \%)$ \\
CT0.5 & $2.529(92,3 \%)$ \\
CT6 & $2.683(98,0 \%)$ \\
CT12 & $2.629(96,0 \%)$ \\
CT24 & $2.273(83,0 \%)$ \\
\hline
\end{tabular}

${ }^{1}$ Tratamentos realizados: $\mathrm{S}$ - variedade susceptível com lagarta, $\mathrm{T}$ - variedade tolerante com lagarta, CS ou CT representam os tratamentos controle

${ }^{2}$ Tempos de tratamento: 0.5 (0.5 h), 6 (6 h), 12 (12 h) e 24 (24 h)

${ }^{3}$ Valores entre parênteses expressam a porcentagem de clones selecionados 


\subsubsection{Análise da Variedade SP80-3280 (Susceptível)}

Dentre os clones que passaram pela normalização, encontraramse 1.466 clones comuns aos quatro tratamentos submetidos à herbivoria (S0.5, S6, S12, S24) e 1.857 nos tratamentos controle (CS0.5, CS6, CS12, CS24). Um total de 1.007 clones foi comum aos dois conjuntos de tratamentos. Para estes 1.007 clones, foram selecionados os clones com log da razão entre valores de leitura dos tratamentos com lagarta que eram 2 vezes maiores ou menores (induzidos ou reprimidos) que os valores de leitura obtidos nos tratamentos das plantas controle.

Os genes induzidos foram agrupados em 4 padrões de expressão: os induzidos em somente um tempo avaliado; os que foram induzidos em dois tempos do experimento; os induzidos em três tempos; e aqueles que foram induzidos nos quatro tempos avaliados no experimento. Trezentos e cinqüenta e oito clones não foram induzidos, 365 apresentaram indução em um dos tempos, 205 em dois tempos, 66 em três tempos e 13 nos quatro tempos avaliados (Tabela 5).

Tabela 5. Número de clones induzidos ou não para a variedade susceptível

\begin{tabular}{crr}
\hline NÃO INDUZIDOS & 358 & \\
\hline INDUZIDOS & 649 & \\
1 TEMPO & & 365 \\
2 TEMPOS & & 205 \\
3 TEMPOS & & 66 \\
4 TEMPOS & & 13 \\
\hline TOTAL & 1.007 & \\
\hline
\end{tabular}


Dos 365 clones induzidos em um dos tempos, 103 foram no tempo de 30 minutos, 108 no tempo de 6 horas, 92 no tempo de 12 horas e 62 no tempo de 24 horas. Os clones estão descritos no APÊNDICE 5 onde também se encontram os respectivos produtos gênicos de cada clone, de acordo com levantamento realizado por Fábio T. S. Nogueira e Vicente E. de Rosa Júnior, ambos do Centro de Biologia Molecular e Engenharia Genética (CBMEG), UNICAMP, Campinas, SP.

Os genes induzidos foram agrupados em diversas classes utilizando-se a classificação funcional descrita no banco de dados do SUCEST. Dezessete classes gênicas foram distinguidas para esta variedade. Este procedimento também foi adotado nos trabalhos de Wang J. (2000), Sasaki et al. (2001) e Nogueira et al. (2003).

A Figura 16 representa a classificação gênica funcional dos clones induzidos uma única vez. Estes genes foram agrupados em dezesseis classes: metabolismo de aminoácidos, crescimento/desenvolvimento, metabolismo de proteínas, metabolismo de RNA, metabolismo secundário, resposta à diferentes condições de estresse, transporte, bioenergética, transdução de sinal, dinâmica celular, metabolismo de DNA, metabolismo de lipídios, elementos móveis, metabolismo de nitrogênio, sulfato e fosfato, metabolismo de nucleotídeos e função não determinada (ND). Nesta última classe, cujos genes têm função desconhecida, foram agrupados os clones denominados de unknow protein, hypothetical protein, putative protein e unable to classify. Através da Figura 16 é possível verificar que a maioria dos genes induzidos tem função não determinada (ND). 

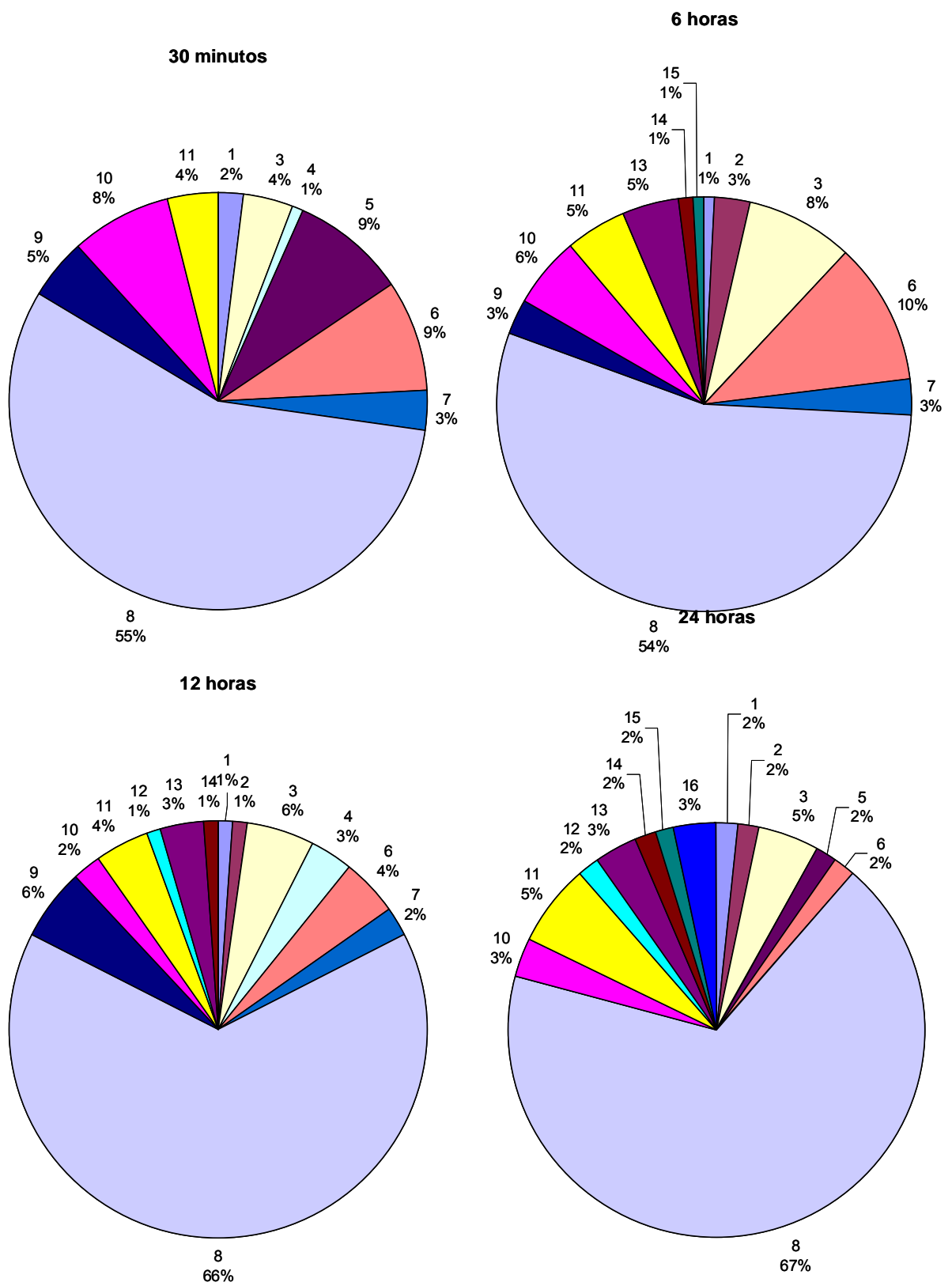

Figura 16 - Diferentes classes gênicas dos clones induzidos uma única vez. Esta classificação está representada da seguinte forma: ${ }^{1}$ met. aa., ${ }^{2}$ crescimento/desenvolvimento, ${ }^{3}$ met. proteína, ${ }^{4}$ met. RNA, ${ }^{5}$ met. $2^{\text {ário }}{ }^{6}$ estresse, ${ }^{7}$ transporte, ${ }^{8} \mathrm{ND}$, ${ }^{9}$ bioenergética, ${ }^{10}$ transdução de sinal, ${ }^{11}$ dinâmica celular, ${ }^{12}$ met. DNA, ${ }^{13}$ met. lipídeos, ${ }^{14}$ elementos móveis, ${ }^{15}$ met. N, S e P, ${ }^{16}$ met. nucleotídeos 
Os 103 genes induzidos no tempo de 30 minutos ( 0.5 hora) foram agrupados em dez classes gênicas. Entre estas, as classes de metabolismo secundário e de resposta ao estresse foram as mais significativas, representando juntas $40 \%$ dos genes identificados, com 9 genes em cada classe. Neste tempo de tratamento ainda não havia sinais de herbivoria nas folhas das plantas com lagartas. Segundo Mauch et al. (1997), movimentos de toque em plântulas de trigo (Triticum aestivum) induziram o aumento dos níveis de transcritos do gene da lipoxigenase (LOX). De acordo com estes autores, a resposta ao toque ocorreu dentro de 1 hora. Bown et al. (2002) demonstraram que o caminhar de lagartas de Heliothis virescens e Choristoneura rosaceana, por 5 a 10 minutos, estimularam a síntese de compostos de defesa em folhas de tabaco e soja respectivamente.

Doze classes foram identificadas no tempo de 6 horas. Em relação ao tempo de 30 minutos, a diferença foi a presença das classes de crescimento/desenvolvimento, de metabolismo de lipídios, de elementos móveis e de metabolismo de nitrogênio, sulfato e fosfato; e a ausência das classes de metabolismo de RNA e de metabolismo secundário. Neste tempo, a classe de resposta ao estresse apresentou 12 genes induzidos, equivalente à $22 \%$ dos genes identificados.

Estavam presentes no tempo de 12 horas treze classes, sendo que as classes de metabolismo de proteínas e de bioenergética apresentaram juntas $10(12 \%)$ genes induzidos, e a $35 \%$ dos genes identificados.

No tempo de 24 horas também foram identificadas treze classes gênicas. A classe com maior número de genes induzidos foi a de dinâmica celular, com 4 genes induzidos, representando $15 \%$ dos genes identificados.

Pôde ser observado que as classes de metabolismo de lipídios e de elementos móveis estavam presentes a partir do tempo de 6 horas. A classe de metabolismo de DNA tornou-se presente a partir do tempo de 12 horas. Os genes das classes de transporte e de bioenergética deixaram de ser induzidos no tempo de 24 horas. 
Para os clones induzidos em dois tempos do experimento, foram selecionados 205 clones. Destes, 39 foram induzidos nos tempos de 6 e 24 horas; 30 nos tempos de 0.5 e 12 horas; 35 nos tempos de 6 e 12 horas; 27 nos tempos de 0.5 e 6 horas; 38 nos tempos de 12 e 24 horas; e 36 clones nos tempos de 0.5 e 24 horas. Tais padrões de indução podem ser observados na Figura 17. Os gráficos A e B desta figura representam genes com comportamento bimodal, ou seja, genes com dois picos de indução intercalados com um retorno aos níveis do controle. O gráfico $\mathrm{C}$, da mesma figura, representa os genes com indução intermediária no processo de herbivoria, enquanto o gráfico $D$ representa os genes responsivos nos primeiros estágios de defesa e o gráfico $E$, os com resposta tardia. $O$ gráfico $F$ representa os clones que se mostraram induzidos no primeiro e no último tempo do experimento. Estes clones estão descritos no APÊNDICE 6, onde também estão descritos os respectivos produtos gênicos. 

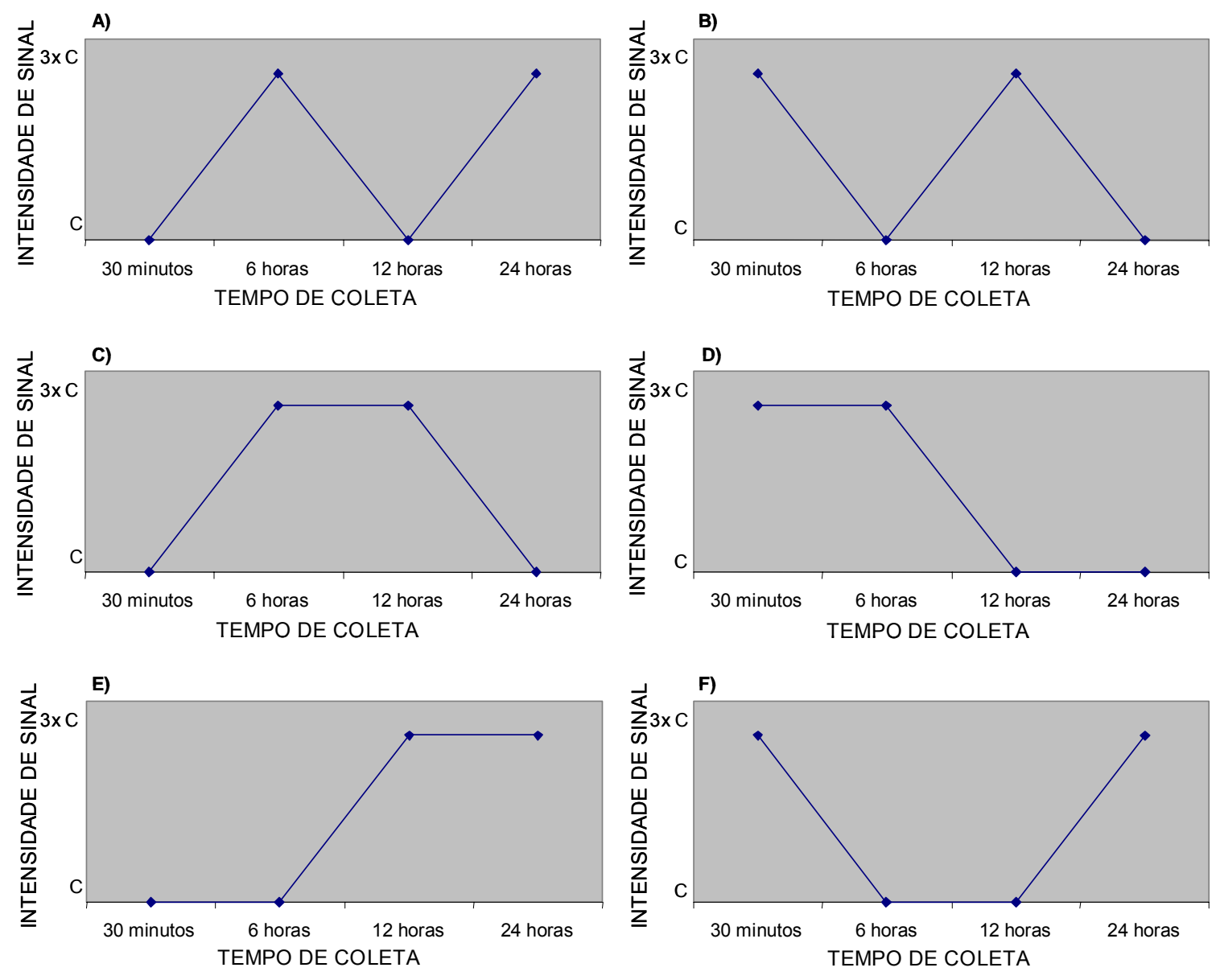

Figura 17 - Padrões de indução gênica em dois tempos do experimento. (A) 6 e $24 \mathrm{~h}$ (B) 0.5 e $12 \mathrm{~h}$ (C) 6 e $12 \mathrm{~h}$ (D) 0.5 e $6 \mathrm{~h}$ (E) 12 e $24 \mathrm{~h}$ (F) 0.5 e $24 \mathrm{~h}$ No eixo $y$ destes gráficos estão os valores $C$ (intensidade de sinal encontrada em plantas controle) e os valores $3 x$ C (indica indução gênica equivalente a pelo menos 3 vezes a intensidade de sinal encontrada nas plantas controle) 
$\mathrm{Na}$ Figura 18 encontra-se a classificação funcional dos clones induzidos em dois tempos do experimento. Assim, nos tempos de 6 e 24 horas, foi possível identificar onze classes gênicas. Entre estas, a classe de bioenergética apresentou 4 genes induzidos, $10 \%$ do número total.

Oito classes gênicas foram identificadas nos tempos de 0.5 e 12 horas. Em relação ao padrão anterior, a diferença foi a presença das classes de metabolismo de DNA e de metabolismo de lipídios; e a ausência das classes de metabolismo de RNA, de proteína de armazenamento, de resposta ao estresse, de transporte e de dinâmica celular. Nestes tempos, a classe de transdução de sinal apresentou 4 genes, 39\% dos identificados. Estes dados corroboram os relatos de Ryan (2000), que mostraram a ativação de componentes da via de transdução de sinais em estágios iniciais do mecanismo de defesa de folhas de tomate submetidas a ferimento mecânico ou sistemina.

Nos tempos de 6 e 12 horas os 35 genes induzidos também foram agrupados em oito classes, a saber: metabolismo de aminoácidos, transporte, transdução de sinal, função não determinada (ND), resposta à diferentes condições de estresse, crescimento/desenvolvimento, bioenergética e de dinâmica celular, sendo que as quatro últimas classes gênicas possuem 2 genes induzidos cada, representando juntas $77 \%$ dos genes identificados.

Foram identificadas sete classes gênicas nos tempos de 0.5 e 6 horas. A classe de elementos móveis apareceu apenas neste padrão e as classes de resposta ao estresse e de transdução de sinal, como pode ser observado na Figura 18, apresentaram 2 genes induzidos cada, representando juntas $14 \%$ do número total de genes induzidos.

Os 38 genes induzidos nos tempos de 12 e 24 horas foram agrupados em dez classes funcionais. Um gene da classe de metabolismo de nucleotídeos foi induzido neste padrão, correspondendo a $8 \%$ dos genes identificados. A classe com o maior número de genes induzidos foi a de metabolismo de proteínas, com 3 genes induzidos. 


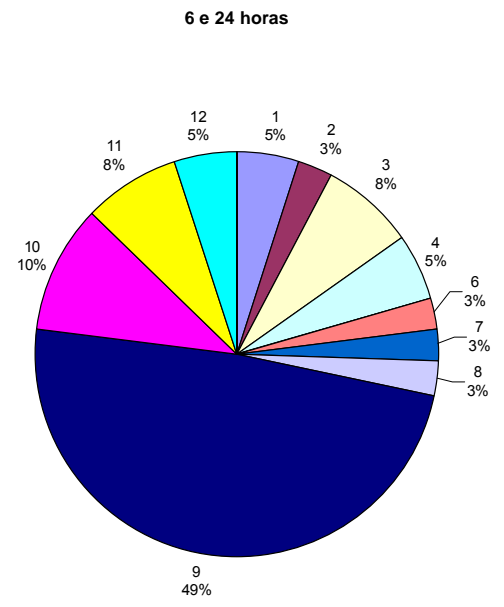

30 minutos e 6 horas

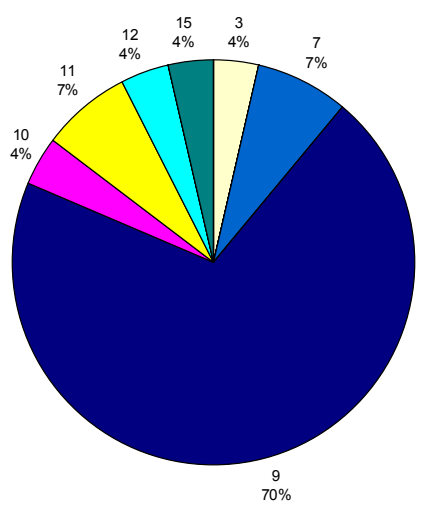

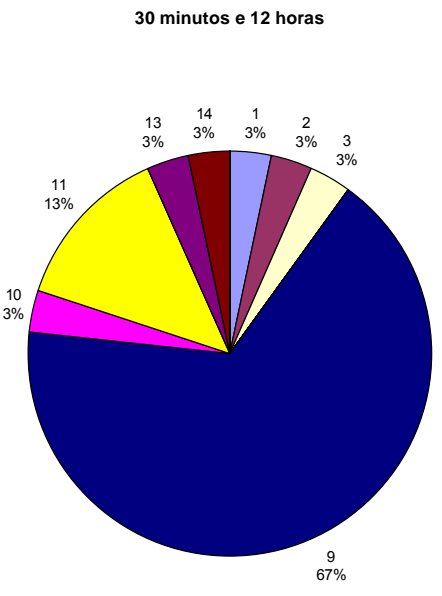

12 e 24 horas

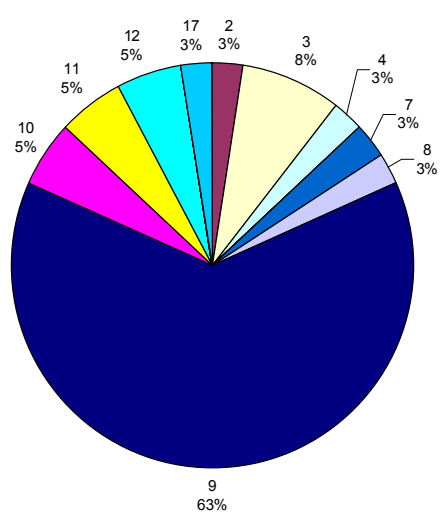

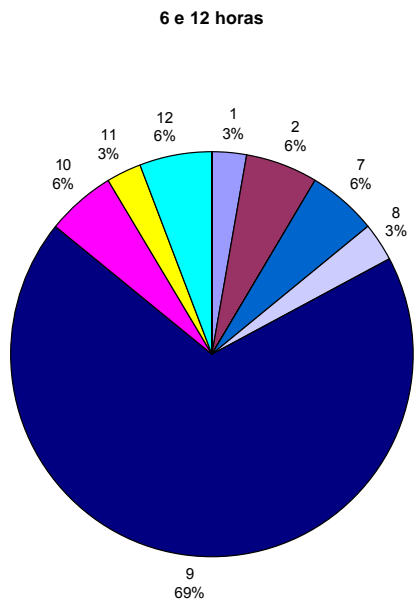

30 minutos e 24 horas

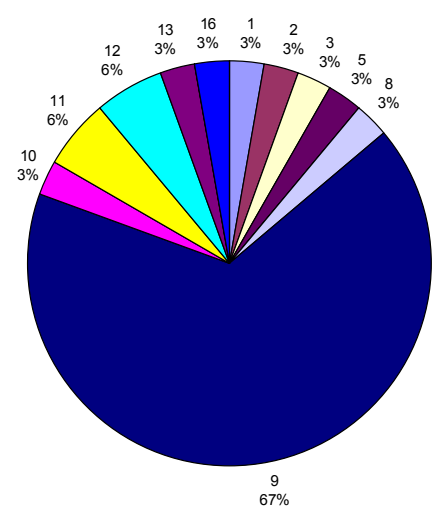

Figura 18 - Diferentes classes gênicas dos clones induzidos duas vezes. Esta classificação está representada da seguinte forma: ${ }^{1}$ met. aa., ${ }^{2}$ crescimento/desenvolvimento, ${ }^{3}$ met. proteína, ${ }^{4}$ met. RNA, ${ }^{5}$ met. $2^{\text {ário }},{ }^{6}$ proteína de armazenamento, ${ }^{7}$ estresse, ${ }^{8}$ transporte, ${ }^{9} \mathrm{ND}$, ${ }^{10}$ bioenergética, ${ }^{11}$ transdução de sinal, ${ }^{12}$ dinâmica celular, ${ }^{13}$ met. DNA, ${ }^{14}$ met. lipídeos, ${ }^{15}$ elementos móveis, ${ }^{16}$ met. N, S e P, ${ }^{17}$ met. nucleotídeos 
Nos tempos de 0.5 e 24 horas, onze classes estavam presentes. A classe de metabolismo de nitrogênio, sulfato e fosfato aparece neste padrão com 1 (3\%) gene induzido. As classes com maior número de genes foram as de transdução de sinal e de dinâmica celular, que apresentaram juntas $36 \%$ dos genes identificados, com 2 genes cada.

Sessenta e seis clones foram induzidos em três tempos do experimento. Catorze foram induzidos nos tempos de $0.5,6$ e 12 horas; 17 foram induzidos nos tempos de 0.5, 6 e 24 horas; 18 foram induzidos nos tempos de 0.5, 12 e 24 horas; e 17 clones foram induzidos nos tempos de 6, 12 e 24 horas. Os padrões de indução destes genes podem ser visualizados na Figura 19. O gráfico A desta figura representa os genes responsivos nos três primeiros tempos do experimento e o gráfico $D$, os com resposta nos três últimos. O gráfico $B$ representa os genes induzidos nos tempos de $0.5,6$ e 24 horas, enquanto o gráfico $C$ representa os genes responsivos nos tempos de 0.5, 12 e 24 horas. Estes clones estão descritos no APÊNDICE 7, que também apresenta os respectivos produtos gênicos de cada clone. 

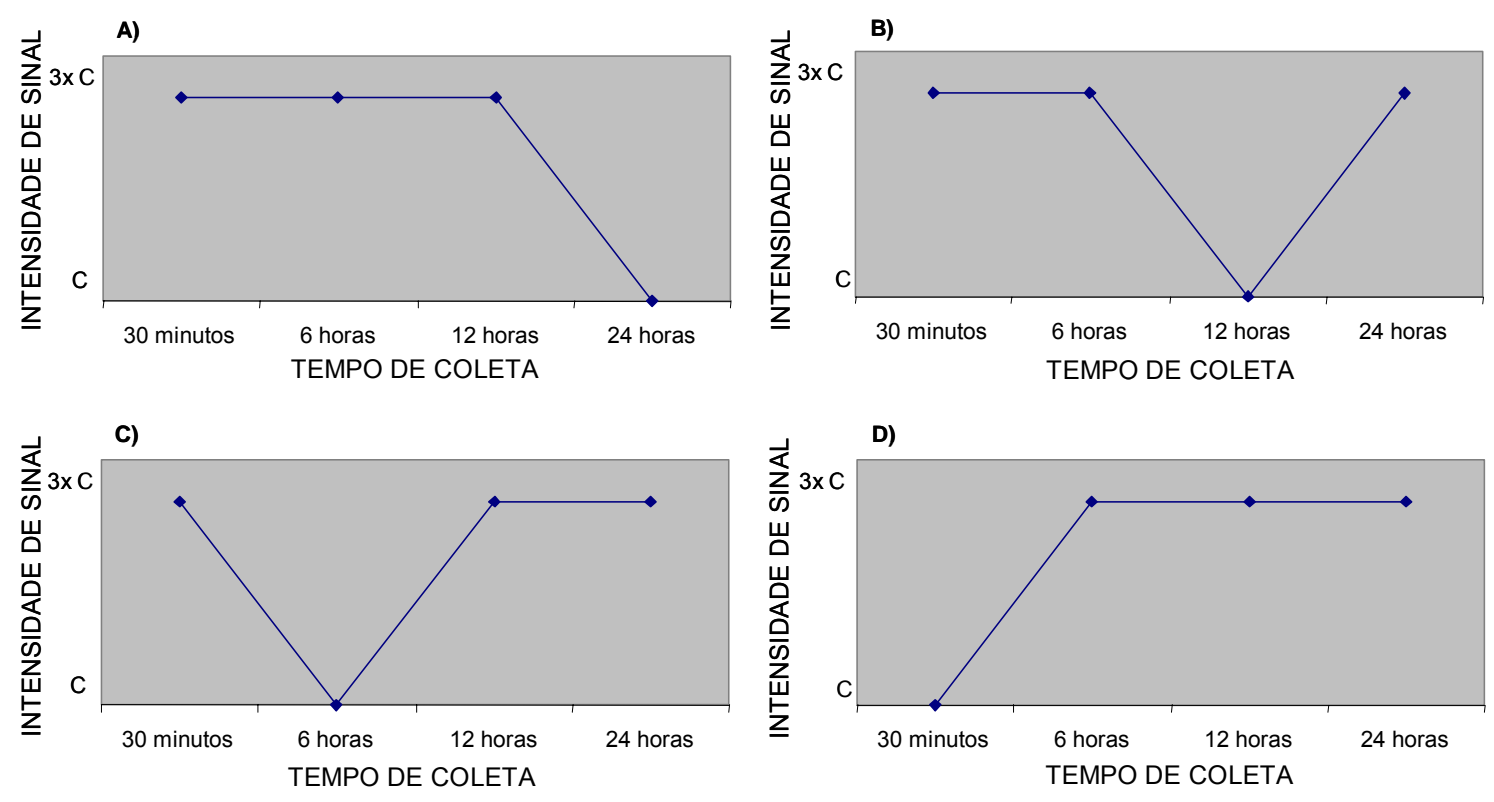

Figura 19 - Padrões de expressão para genes induzidos em três tempos do experimento. (A) $0.5,6$ e $12 \mathrm{~h}$ (B) $0.5,6$ e $24 \mathrm{~h}$ (C) $0.5,12$ e $24 \mathrm{~h}$ (D) 6,12 e $24 \mathrm{~h}$ No eixo $y$ destes gráficos estão os valores $C$ (intensidade de sinal emitida pelo tratamento controle) e os valores $3 \times \mathrm{C}$ (intensidade de sinal emitida pelo tratamento com lagartas, indicando que aquele clone foi induzido)

Na Figura 20 podem ser observados os grupos gênicos induzidos em 3 tempos do experimento. Estes genes foram agrupados em onze classes: metabolismo de aminoácidos, crescimento/desenvolvimento, metabolismo de proteínas, metabolismo de RNA, resposta ao estresse, transporte, bioenergética, transdução de sinal, metabolismo de DNA, metabolismo de lipídios e de proteínas de função não determinada (ND). Através desta figura é possível verificar que a maioria dos genes induzidos tem função não determinada (ND). 


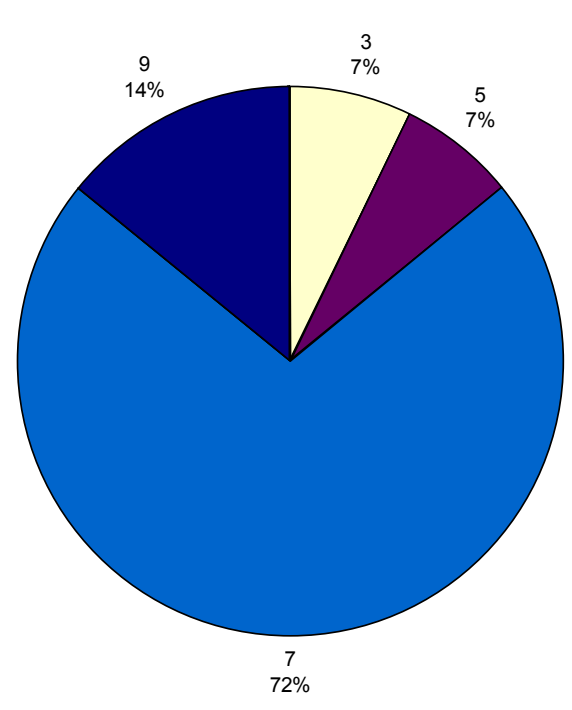

30 minutos, 12 horas e 24 horas

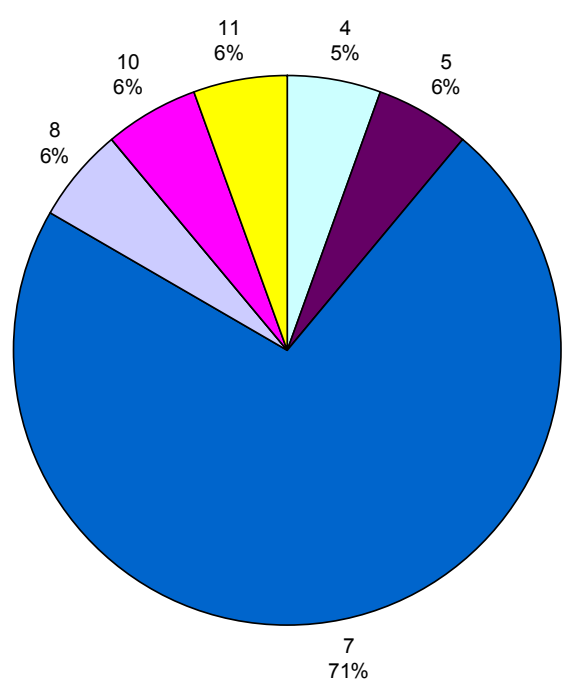

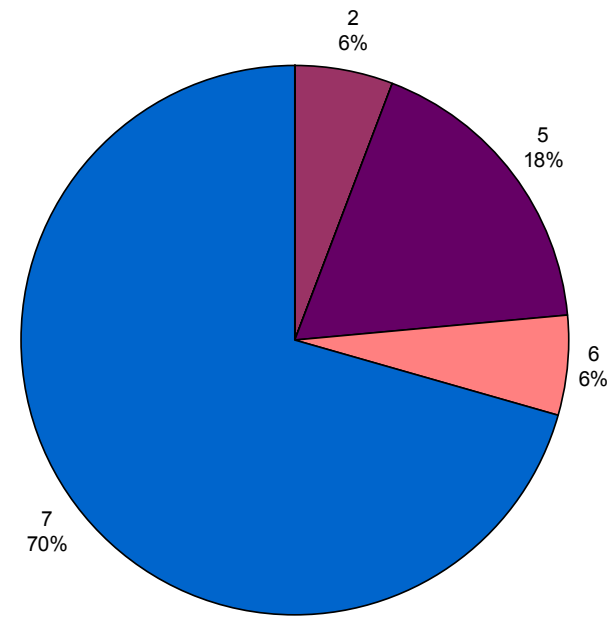

6 horas, 12 horas e 24 horas

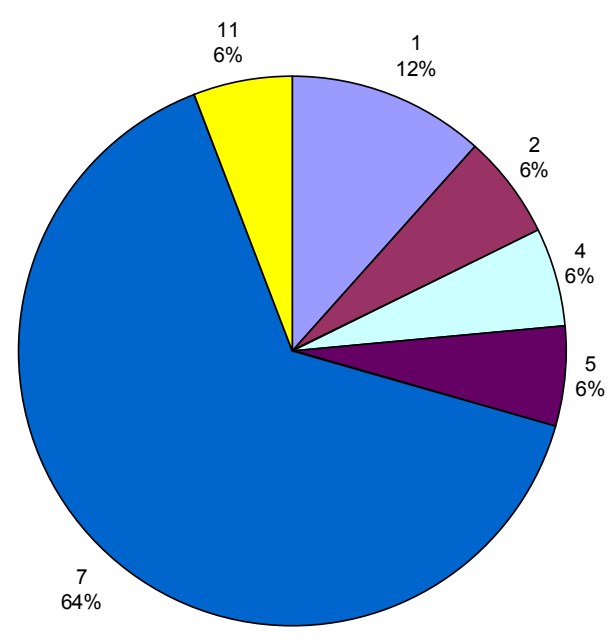

Figura 20 - Diferentes classes gênicas dos clones induzidos três vezes. Esta classificação está representada da seguinte forma: : ${ }^{1}$ met. aa., ${ }^{2}$ crescimento/desenvolvimento, ${ }^{3}$ met. proteína, ${ }^{4}$ met. RNA, ${ }^{5}$ estresse, ${ }^{6}$ transporte, ${ }^{7} \mathrm{ND},{ }^{8}$ bioenergética, ${ }^{9}$ transdução de sinal, ${ }^{10}$ met. DNA, ${ }^{11}$ met. lipídeos 
Foram identificadas quatro classes gênicas nos tempos de 0.5, $6 \mathrm{e}$ 12 horas: metabolismo de proteínas, resposta ao estresse, transdução de sinal e função não determinada (ND). Entre estas, a classe de transdução de sinal apresentou 2 genes, representando $50 \%$ dos identificados. Uma das proteínas envolvidas nesta via são as quinases. Segundo Bögre et al. (1997), ferimentos mecânicos em folhas de alfafa induziram a ativação de um grupo específico de MAP quinases (mitogen-activated protein kinases) nos estágios iniciais do mecanismo de defesa. Estes dados também estão de acordo com relatos de Seo et al. (1999), que verificaram o aumento nos níveis de proteínas quinases em plantas de tabaco submetidas à ferimentos. A ativação de quinases também foi reportada em respostas da defesa contra patógenos e elicitores (Zhang \& Klessig, 1998; Romeis et al., 1999; Yang et al., 2001).

Nos tempos de 0.5, 6 e 24 horas também foram identificadas quatro classes gênicas: crescimento/desenvolvimento, resposta ao estresse, transporte e proteínas cuja função ainda é desconhecida (ND). Nestes tempos, a classe de genes responsivos à diferentes tipos de estresses apresentou 3 genes induzidos, $18 \%$ dos identificados.

Seis classes gênicas estavam presentes nos tempos de 0.5, $12 \mathrm{e}$ 24 horas: metabolismo de RNA, resposta ao estresse, bioenergética, metabolismo de DNA, metabolismo de lipídios e a classe de genes com função não determinada (ND). Todas as classes, com exceção da classe de genes com função não determinada (ND), apresentaram 1 gene induzido.

No padrão de expressão dos tempos de 6, 12 e 24 horas, de acordo com a Figura 20, também foram encontradas seis classes funcionais: metabolismo de aminoácidos, crescimento/desenvolvimento, metabolismo de RNA, resposta ao estresse, metabolismo de lipídios e de função não determinada (ND). A classe de metabolismo de aminoácidos foi a mais representativa, com 2 genes induzidos (33\% dos genes identificados). 
Categorização dos genes induzidos nos quatro tempos de tratamento

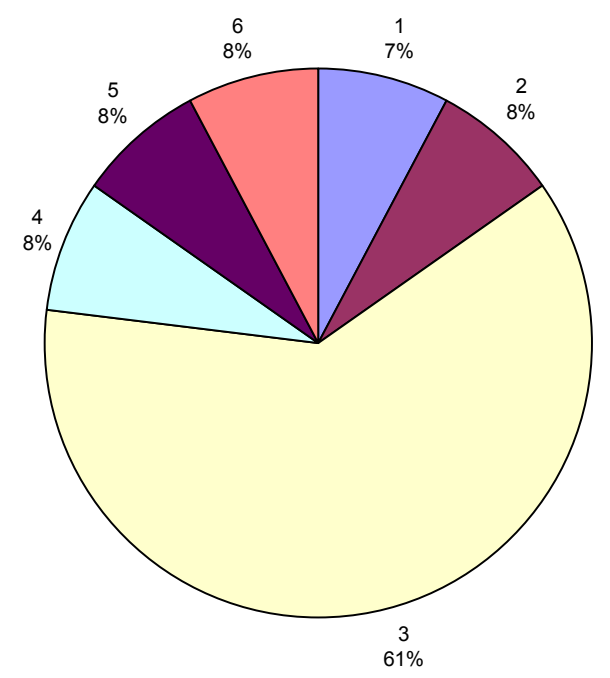

Figura 21 - Classes de genes induzidos em todos os tempos de tratamento. Esta classificação está representada da seguinte forma: ${ }^{1}$ met. aa., ${ }^{2}$ resposta ao estresse, ${ }^{3} \mathrm{ND}$, ${ }^{4}$ bioenergética, ${ }^{5}$ transdução de sinal, ${ }^{6}$ dinâmica celular

Treze genes foram induzidos nos quatro tempos. Estes clones estão listados no APÊNDICE 8, onde estão descritos também seus respectivos produtos gênicos. A Figura 21 apresenta o agrupamento destes clones, os quais foram agrupados em seis classes: metabolismo de proteínas, resposta ao estresse, bioenergética, transdução de sinal, dinâmica celular e função não determinada (ND). A partir desta figura, como nos outros padrões de expressão gênica, pôde ser observado que existem muitos genes induzidos cuja função ainda é desconhecida (ND). Em relação às demais classes, somente 1 gene foi induzido em cada. 
Os resultados obtidos para a variedade susceptível (SP80-3280) estão resumidamente apresentados na Tabela 6. Estes dados mostram que 270 genes foram induzidos no tempo de 6 horas, tempo com o maior número de genes induzidos. Já o tempo com o menor número foi o de 24 horas (com 240 induções). Os tempos de 30 minutos ( 0.5 hora) e de 12 horas apresentaram 258 e 257 genes induzidos respectivamente.

Dos 246 genes identificados, a classe menos representada foi a de proteína de armazenamento (um gene identificado). A classe com maior número de genes identificados foi a de resposta ao estresse, com 39 genes, seguida das classes de transdução de sinal e de metabolismo de proteínas, com 35 e 32 genes identificados respectivamente.

Analisando as classes gênicas em cada tempo (Tabela 6), é possível observar que algumas tiveram genes identificados em determinados tempos de indução, como foi o caso das classes de metabolismo secundário, de proteína de armazenamento, de metabolismo de nitrogênio, sulfato e fosfato e de metabolismo de nucleotídeos. 
Tabela 6. Número de genes induzidos para cada classe funcional apresentada na variedade susceptível

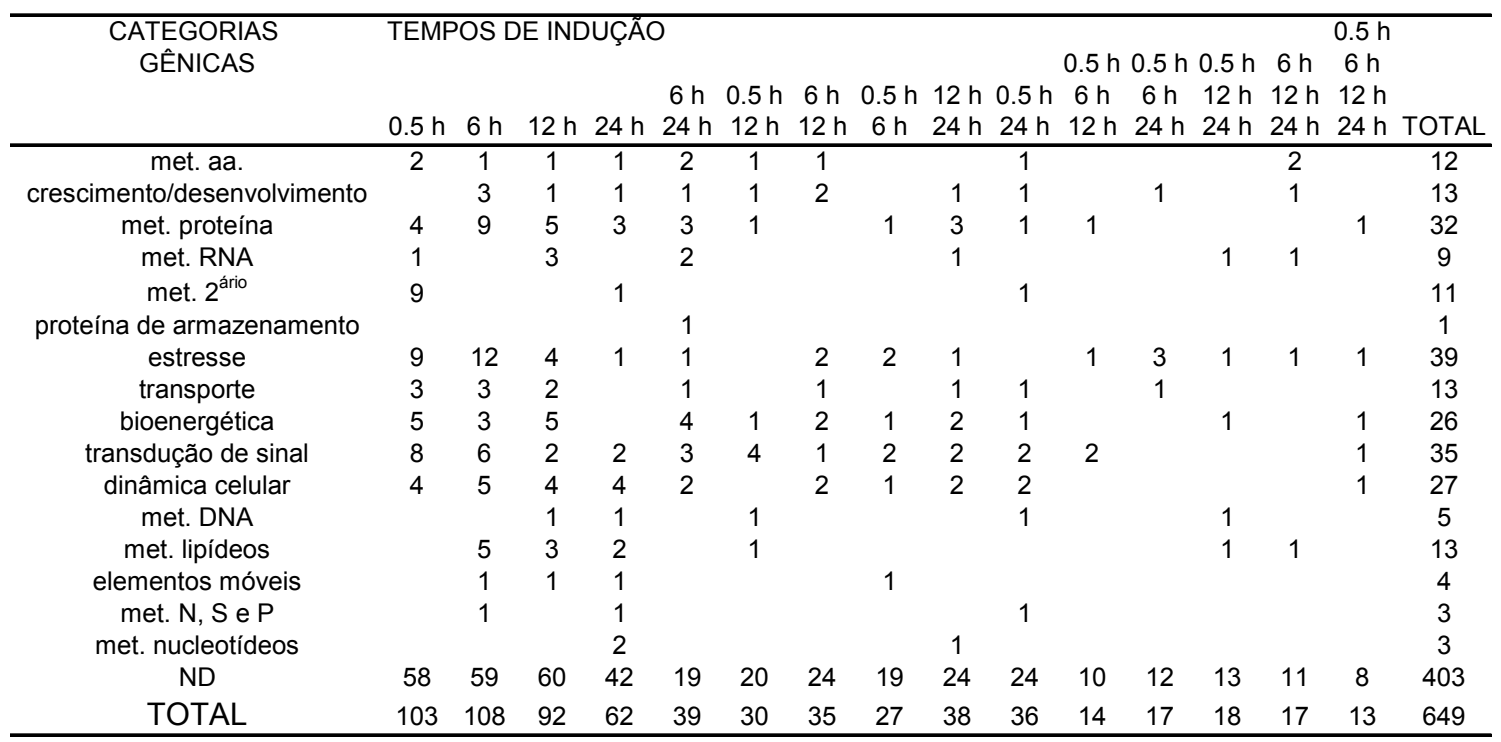

Onze genes relacionados ao metabolismo secundário foram induzidos nos tempos de 30 minutos ( 0.5 hora; tempo mais representativo com 9 genes induzidos), um gene foi encontrado induzido no tempo de 24 horas e um clone presente nos tempos de 0.5 e 24 horas (Tabela 6). Entre estes genes estão: flavonol 3-O-glucosyltransferase-like protein, jacalin homolog, putative flavonoid 3'-hydroxylase, isoflavone reductase, arginine decarboxylase, phenylalanine ammonia-lyase, dihydrokaempferol 4-reductase $A$ e putative cinnamyl-alcohol dehydrogenase. Estas substâncias podem ser agrupadas na classe dos compostos fenólicos, que consistem de um anel aromático, ao qual se ligam grupos do tipo hidroxila, carboxila e metoxila. A maioria é solúvel em água e ocorrem na forma de glicosídeos. Eles são originados a partir da via do ácido chiquímico e acumulam-se nos vacúolos das células vegetais. Os compostos fenólicos presentes nas plantas possuem diferentes efeitos sobre os 
herbívoros (Gazzoni et al., 1997). A ativação desses compostos ocorre por oxidação, conforme estabelecido por Appel (1993). Segundo este autor, tais compostos inibem o consumo foliar e a digestão de determinados insetos, além de serem formadores de radicais livres. O efeito deterrente está relacionado à sensação adstringente, decorrente da capacidade dos compostos fenólicos em precipitar proteínas. A inibição da digestão pode ocorrer devido à formação de pontes de hidrogênio, ou ainda pela formação de ligações covalentes, com proteínas e enzimas digestivas. Ainda segundo Appel (1993), os radicais de hidroxila formados durante a oxidação dos compostos fenólicos possuem ação tóxica, pois ocasionam a ruptura da integridade da membrana e distúrbios de metabolismo no epitélio intestinal. Os flavonóides são compostos fenólicos, amplamente encontrados em materiais vegetais (Harborne, 1991). Nenhuma função universal referente aos flavonóides e seus glicosídeos foi estabelecida em relação a todas as plantas. Contudo, muitas funções em plantas específicas tem sido demonstradas, incluindo proteção contra raios ultravioleta, insetos, fungos, vírus e bactérias (Markham, 1989). Chiang et al. (1987), estudando plantas de soja submetidas à Epilachna varivestis, concluíram que o aumento do efeito anti-herbivoria estava correlacionado com os níveis de compostos fenólicos, onde foi observado uma alta atividade das enzimas PAL (Lfenilalanina amônia-liase) e TAL (L-tirosina amonia-liase). Já Sharma \& Norris (1991), analisando nove compostos extraídos de soja, relataram que os flavonóides encontrados exibiram efeito deterrente ou antibiótico contra as larvas de Trichoplusia ni Hübner.

Patatin foi o único transcrito relatado na classe de proteína de armazenamento e foi induzido nos tempos de 6 e 24 horas. Esta glicoproteína, pertencente à família das fosfolipases, constitui de 20 a 40\% da proteína total solúvel de tubérculos de batata (Racusen \& Foote, 1980). Patatin é uma proteína de armazenamento que apresenta também atividade enzimática, hidrolisando ácidos graxos da membrana. Dados indicam que a patatin é uma enzima bioativa da planta com a atividade anti-nutritiva, como $\alpha$-amilase, 
inibidores de protease, lecitinas e globulinas (Negreiros et al., 1991; Sales et al., 2000; Franco et al., 2002). Strickland et al. (1995) observaram que o crescimento de lagartas de Diabrotica $s p$. foi inibido devido à dieta com patatin obtida de plantas de batata. Os autores sugerem que a patatin pode representar uma nova classe de proteínas para o controle de pragas.

Os genes induzidos da classe de metabolismo de nitrogênio, sulfato e fosfato, apresentados a seguir, estavam presentes nos tempos de 0.5 , 6 e 24 horas respectivamente: MtN3, nodulin-like protein e DsPTP1 protein. A fixação simbiótica do nitrogênio é dependente da nitrogenase, uma enzima instável e reativa ao oxigênio. Para proteger as nitrogenases bacterianas da inativação pelo oxigênio $\left(\mathrm{O}_{2}\right)$, a concentração de oxigênio $\left[\mathrm{O}_{2}\right]$ é mantida em um nível muito baixo nos nódulos infectados de leguminosas. Segundo Kuzma et al. (1993), a presença das leghemoglobinas nestes nódulos faz com que a $\left[\mathrm{O}_{2}\right]$ seja de 30 a $50 \mathrm{nM}$ em nódulos fixadores ativos, enquanto a $\left[\mathrm{O}_{2}\right]$ na água do solo em equilíbrio com a atmosfera é de aproximadamente $260 \mu \mathrm{M}$. Uma outra proteína que pode estar envolvida no regulamento da barreira de difusão é a nodulina (Nap \& Bisseling, 1990). Acúmulos de transcritos que codificam esta proteína foram encontradas em nódulos ativos de soja, ervilha, alfafa e feijão (Van de Wiel et al., 1990; Trese \& Pueppke, 1991; Dehio \& de Bruijn, 1992). Uma terceira proteína, a lecitina, foi encontrada em nódulos de amendoim (VandenBosch et al., 1994). Em relação aos genes envolvidos no metabolismo de enxofre, Maruyama-Nakashita et al. (2003) relataram que as plantas utilizam o sulfato para a síntese de vários compostos orgânicos, de acordo com Grossman \& Takahashi (2001). Uma vez incorporado pela planta, o sulfato é reduzido e torna-se um constituinte das proteínas essenciais cisteína e metionina. A cisteína (Cys) é utilizada na produção da glutationa (GSH), que serve tanto para o controle redox, redução e oxidação de substâncias celulares, como também para a conjugação xenobiótica, ligando-se a compostos não degradados pelos organismos no ambiente (Asada, 1999). O enxofre é um elemento importante para os vegetais pois ele é convertido a uma ampla 
variação de compostos secundários, essenciais para o regulamento e para a adaptação do crescimento aos estresses ambientais (Benning, 1998).

A classe de metabolismo de nucleotídeos, de acordo com a Tabela 6, teve três genes induzidos, dois no tempo de 24 horas (glycyl-tRNA synthetase e putative nucleotide sugar epimerase) e um nos tempos de 12 e 24 horas (ADP-ribosylation factor-like protein).

Os resultados apresentados na Tabela 6 também mostram que algumas classes gênicas funcionais foram induzidas em todos os tempos do experimento, tais como: metabolismo de proteínas, resposta ao estresse, bioenergética, transdução de sinal e dinâmica celular. A classe de elementos móveis, com 4 genes induzidos, não apresentou indução somente no tempo de 30 minutos ( 0.5 hora), tempo no qual as lagartas de $D$. saccharalis ainda não haviam causado danos nas plantas de cana-de-açúcar. Estudos recentes mostraram que elementos móveis podem ser induzidos por fatores ambientais, tais como ataque de herbívoros e elicitação por ácido jasmônico ou por ferimento mecânico (Capy et al., 2000; Heil \& Baldwin, 2002). Também foi possível observar que a classe de metabolismo de DNA não teve genes induzidos no tempo de 6 horas. 


\subsubsection{Análise da Variedade SP81-3250 (Tolerante)}

Para esta variedade foram encontrados 1.791 clones comuns aos quatro tratamentos de herbivoria (T0.5, T6, T12, T24) e 2.079 nos tratamentos controle (CT0.5, CT6, CT12, СT24). Destes, 1.358 clones estavam presentes nos dois conjuntos de experimentos. Conforme realizado para a variedade susceptível, foram selecionados somente os clones 2 vezes maiores ou menores (induzidos ou reprimidos) em relação ao log da razão entre valores de leitura dos tratamentos com lagarta e os valores de leitura obtidos nos tratamentos das plantas controle. Uma vez selecionados, estes clones também foram agrupados em 4 padrões de indução da expressão gênica em resposta à herbivoria, como pode ser observado na Tabela 7.

Tabela 7. Número de clones induzidos ou não para a variedade tolerante

\begin{tabular}{crr}
\hline NÃO INDUZIDOS & 532 & \\
\hline INDUZIDOS & 791 & \\
1 TEMPO & & 415 \\
2 TEMPOS & & 285 \\
3 TEMPOS & & 70 \\
4 TEMPOS & & 21 \\
\hline TOTAL & 1.323 & \\
\hline
\end{tabular}

De acordo com a Tabela 7, verificou-se que 532 clones não apresentaram sinal de indução, 415 foram induzidos em um dos tempos do experimento, $285 \mathrm{em}$ dois tempos, 70 em três tempos e 21 nos quatro tempos de tratamento. Para esta variedade foram descritas dezessete classes gênicas funcionais. 
Quatrocentos e quinze clones foram induzidos em um dos tempos do experimento, sendo 86 no tempo de 30 minutos ( 0.5 hora), 150 no tempo de 6 horas, 67 no tempo de 12 horas e 112 no tempo 24 de horas. Os clones e seus respectivos produtos gênicos estão descritos no APÊNDICE 9.

Os clones induzidos uma única vez foram agrupados em dezessete classes gênicas funcionais, a saber: metabolismo de aminoácidos, crescimento/desenvolvimento, metabolismo de proteínas, metabolismo de RNA, metabolismo secundário, proteína de armazenamento, resposta ao estresse, transporte, bioenergética, transdução de sinal, dinâmica celular, metabolismo de DNA, metabolismo de lipídios, elementos móveis, metabolismo de nitrogênio, sulfato e fosfato, metabolismo de nucleotídeos e função não determinada (ND). Através da Figura 22 é possível verificar que a maioria dos genes induzidos tem função desconhecida (classe ND).

No tempo de 30 minutos ( 0.5 hora), onde ainda não havia sinal de herbivoria nas plantas, os 86 genes induzidos foram agrupados em treze classes gênicas. Entre estas, a classe de resposta ao estresse foi a que apresentou um maior número de genes em relação às demais, 8 genes, representando $18 \%$ dos genes identificados.

Catorze classes foram identificadas no tempo de 6 horas. Em relação ao tempo de 30 minutos, a diferença foi a presença da classe de metabolismo de nitrogênio, sulfato e fosfato. Neste tempo, a classe de dinâmica celular foi a que mostrou maior porcentagem de genes induzidos (7\%), com 10 genes identificados.

Os 67 genes induzidos no tempo de 12 horas foram agrupados em treze classes gênicas. Em relação ao tempo anterior, a diferença foi a presença da classe de metabolismo de lipídios, e a ausência das classes de elementos móveis e de metabolismo de nitrogênio, sulfato e fosfato. Neste tempo, a classe de metabolismo de proteínas apresentou 7 genes induzidos, equivalente à $25 \%$ dos genes identificados. 

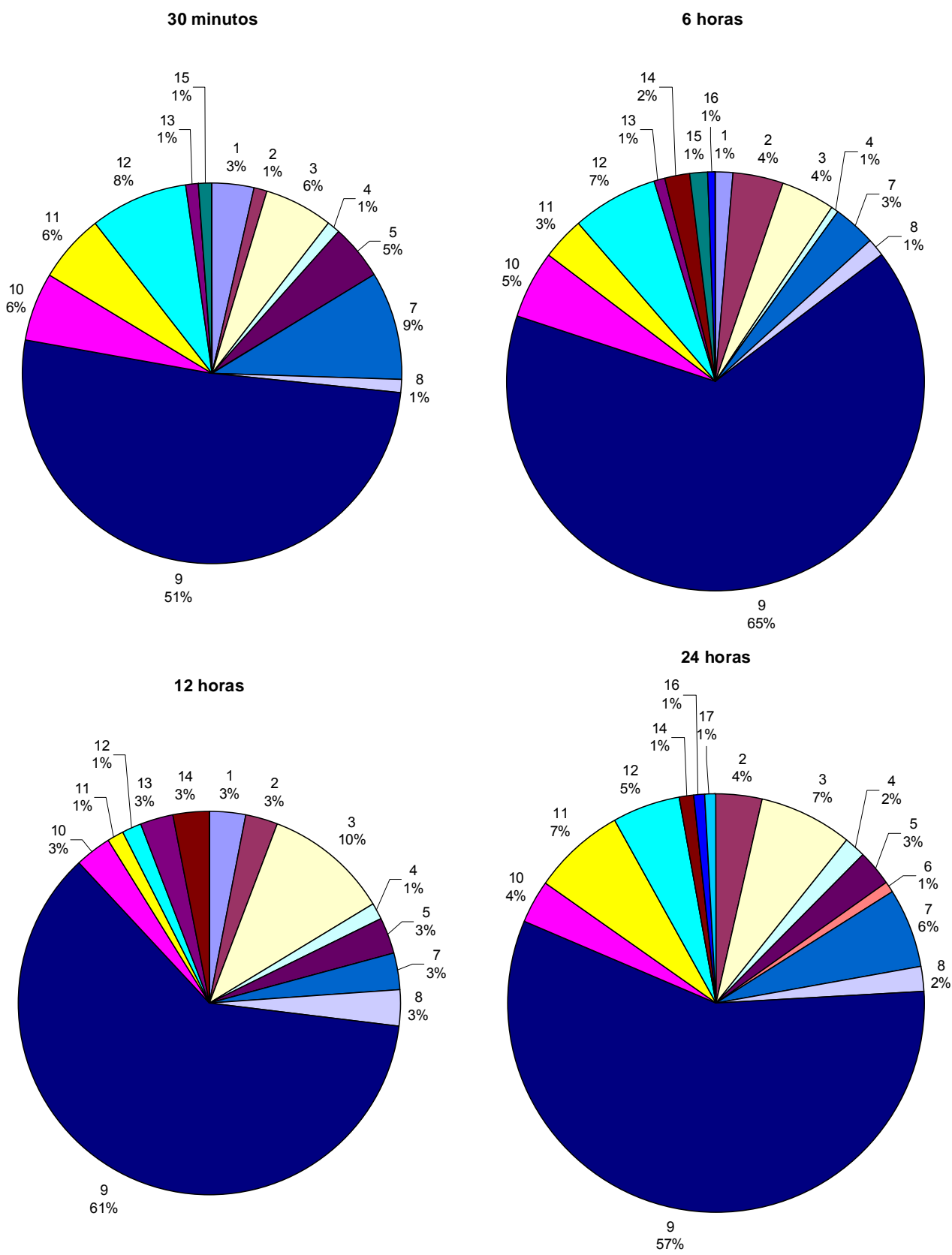

Figura 22 - Classes dos clones induzidos uma única vez, representados da seguinte forma: ${ }^{1}$ met. aa., ${ }^{2}$ crescimento/desenvolvimento, ${ }^{3}$ met. proteína, ${ }^{4}$ met. RNA, ${ }^{5}$ met. $2^{\text {ário }}$, ${ }^{6}$ roteína de armazenamento, ${ }^{7}$ estresse, ${ }^{8}$ transporte, ${ }^{9} \mathrm{ND},{ }^{10}$ bioenergética, ${ }^{11}$ transdução de sinal, ${ }^{12}$ dinâmica celular, ${ }^{13}$ met. DNA, ${ }^{14}$ met. lipídeos, ${ }^{15}$ elementos móveis, ${ }^{16}$ met. N, S e P, ${ }^{17}$ met. nucleotídeos 
Estavam presentes no tempo de 24 horas catorze classes. As classes com maior número de genes induzidos foram as de metabolismo de proteínas e de transdução de sinal, com 8 genes identificados em cada, representando juntas $14 \%$ dos genes induzidos.

Constatou-se que a classe de metabolismo de nitrogênio, sulfato e fosfato só foi induzida nos tempos de 6 e 24 horas. Já a classe de metabolismo secundário foi induzida nos tempos de 0.5 e 12 horas. A classe de metabolismo de lipídios não foi induzida no tempo de 30 minutos ( 0.5 hora), e as classes de proteína de armazenamento e de metabolismo de nucleotídeos estiveram presentes somente no tempo de 24 horas. Os genes da classe de elementos móveis deixam de ser induzidos a partir do tempo 12 horas, e os das classes de metabolismo de aminoácidos e de metabolismo de DNA não foram identificados como induzidos no tempo de 24 horas.

No padrão de indução em dois tempos do experimento, como descrito anteriormente (Figura 17), foram selecionados 285 clones, nos quais, 55 foram induzidos nos tempos de 6 e 24 horas; 44 nos tempos de 0.5 e 12 horas; 56 nos tempos de 6 e 12 horas; 49 nos tempos de 0.5 e 6 horas; 45 nos tempos de 12 e 24 horas; e 36 clones nos tempos de 0.5 e 24 horas. Estes clones estão descritos no APÊNDICE 10, onde também estão descritos os respectivos produtos gênicos.

A Figura 23 apresenta a classificação funcional dos clones induzidos em dois tempos de tratamento. Estes genes foram agrupados em quinze classes: metabolismo de aminoácidos, crescimento/desenvolvimento, metabolismo de proteínas, metabolismo de RNA, metabolismo secundário, resposta ao estresse, transporte, bioenergética, transdução de sinal, dinâmica celular, metabolismo de DNA, metabolismo de lipídios, elementos móveis, metabolismo de nucleotídeos e a classe dos genes com função não determinada (ND). Através desta figura é possível verificar que a maioria dos genes induzidos tem função não conhecida. 


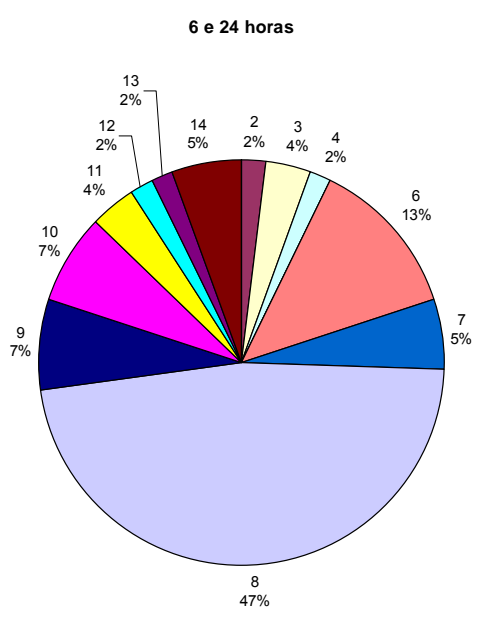

30 minutos e 6 horas

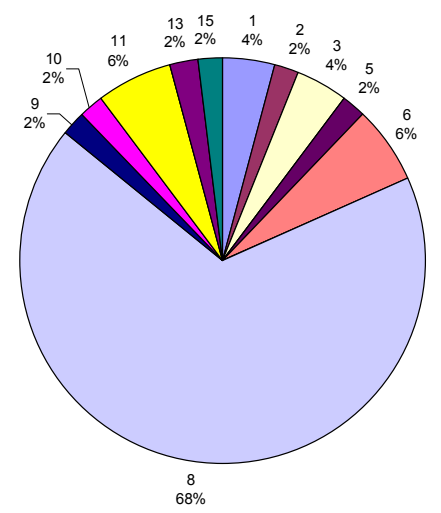

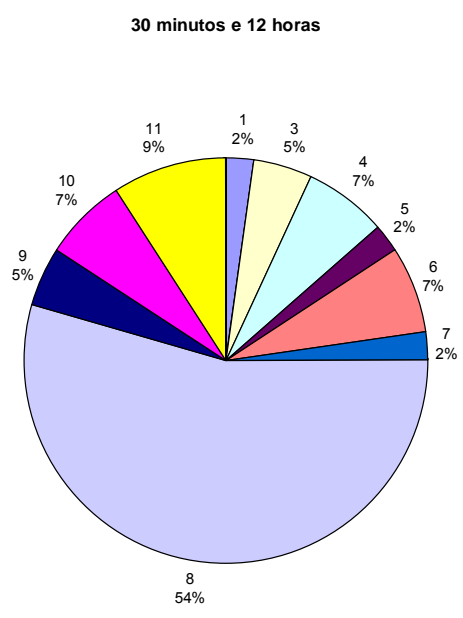

12 e 24 horas

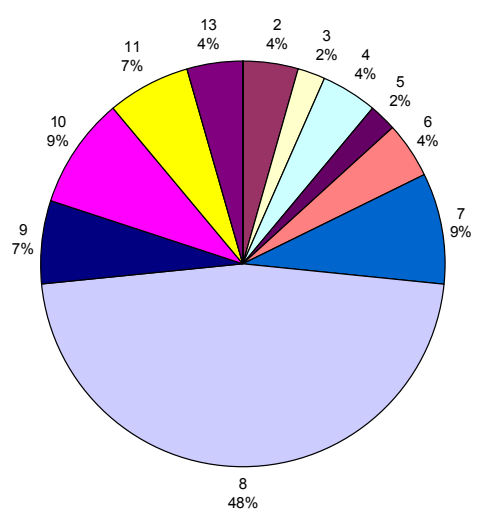

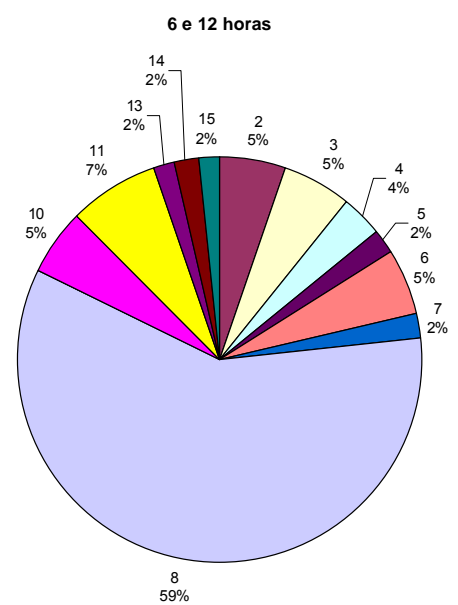

30 minutos e 24 horas

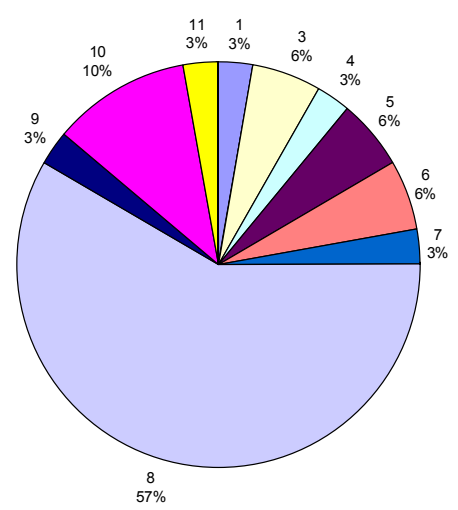

Figura 23 - Diferentes classes gênicas dos clones induzidos duas vezes. Esta classificação está representada da seguinte forma: ${ }^{1}$ met. aa., ${ }^{2}$ crescimento/desenvolvimento, ${ }^{3}$ met. proteína, ${ }^{4}$ met. RNA, ${ }^{5}$ met. secundário, $\quad{ }^{6}$ estresse, $\quad{ }^{7}$ transporte, ${ }^{8} \mathrm{ND}, \quad{ }^{9}$ bioenergética, ${ }^{10}$ transdução de sinal, ${ }^{11}$ dinâmica celular, ${ }^{12}$ met. DNA, ${ }^{13}$ met. lipídeos, ${ }^{14}$ elementos móveis, ${ }^{15}$ met. nucleotídeos 
Os 55 genes induzidos nos tempos de 6 e 24 horas foram agrupados em doze classes gênicas. A classe de resposta ao estresse apresentou 7 genes induzidos, representando $25 \%$ dos genes identificados.

Foram identificadas dez classes nos tempos de 0.5 e 12 horas. Nestes tempos, a classe de dinâmica celular apresentou $9 \%$ dos genes induzidos, equivalendo a 4 genes identificados.

Cinqüenta e seis genes foram agrupados em doze classes gênicas nos tempos de 6 e 12 horas. A classe contendo os genes de dinâmica celular foi a mais representativa, com 4 genes identificados (17\%).

Onze classes estavam presentes nos tempos de 0.5 e 6 horas: metabolismo de aminoácidos, crescimento/desenvolvimento, metabolismo de proteínas, metabolismo secundário, resposta ao estresse, bioenergética, transdução de sinal, dinâmica celular, metabolismo de lipídios, metabolismo de nucleotídeos e a classe dos genes com função não determinada (ND). As classes com maior número de genes induzidos foram as de resposta ao estresse e de metabolismo de lipídios, com 3 genes identificados em cada.

Nos tempos de 12 e 24 horas, os 45 genes induzidos foram agrupados em onze classes, todas observadas no padrão anterior com exceção da classe de metabolismo de nucleotídeos, e com o acréscimo da classe de genes relacionados ao transporte celular. As classes de transdução de sinal e de transporte tiveram 4 genes induzidos cada, representando juntas $35 \%$ dos genes identificados.

Estavam presentes nos tempos de 0.5 e 24 horas dez classes gênicas. A classe de transdução de sinal se destacou mais uma vez como a classe mais representada, constituindo-se de 4 genes, $11 \%$ dos identificados.

Para os genes com padrão de indução em dois tempos, foi observado que as classes funcionais de metabolismo de proteínas, de resposta ao estresse, de transdução de sinal e de dinâmica celular foram as mais induzidas neste padrão. 
Dos setenta clones que foram induzidos em três tempos do experimento, 18 foram induzidos nos tempos de $0.5,6$ e 12 horas; 16 foram induzidos nos tempos de 0.5 , 6 e 24 horas; 11 foram induzidos nos tempos de 0.5, 12 e 24 horas; e 25 clones foram induzidos nos tempos de 6, 12 e 24 horas. Estes clones e seus respectivos produtos gênicos estão descritos no APÊNDICE 11.

Estes clones seguem o mesmo padrão de expressão gênica descrito na Figura 19, e foram agrupados em treze classes gênicas funcionais: crescimento/desenvolvimento, metabolismo de proteínas, metabolismo de RNA, proteína de armazenamento, resposta ao estresse, transporte, bioenergética, transdução de sinal, dinâmica celular, metabolismo de lipídios, elementos móveis, metabolismo de nucleotídeos e função não determinada (ND). A Figura 24 apresenta o agrupamento destes clones. Através desta figura é possível verificar que a maioria dos genes induzidos tem função não determinada (ND).

Oito classes gênicas agruparam os 18 genes induzidos nos tempos de 0.5, 6 e 12 horas: crescimento/desenvolvimento, metabolismo de RNA, transporte, bioenergética, transdução de sinal, dinâmica celular, metabolismo de lipídios e função não determinada (ND). A classe relacionada à bioenergética apresentou 2 genes, sendo a classe com o maior número de genes induzidos em relação às demais.

No padrão de expressão dos tempos de $0.5,6$ e 24 horas foram identificadas quatro classes gênicas: resposta ao estresse, bioenergética, elementos móveis e função não determinada (ND). A classe de resposta ao estresse foi a que apresentou a maior porcentagem de genes induzidos em relação às demais (19\%), com 3 genes identificados. 


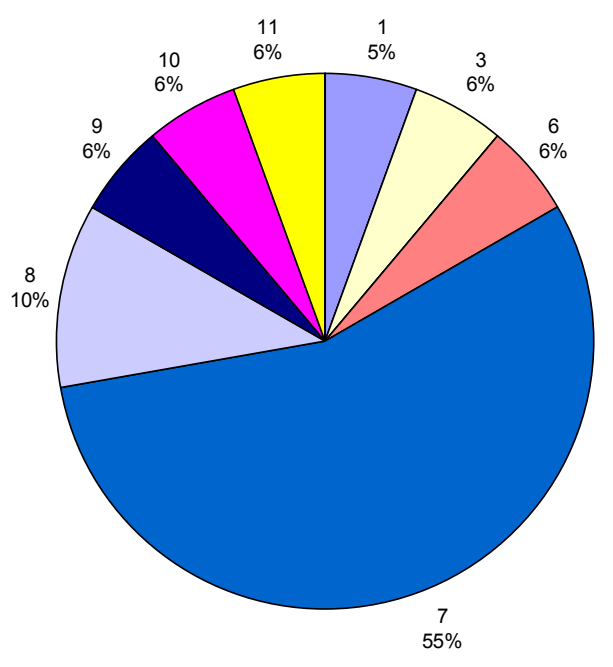

30 minutos, 12 horas e 24 horas

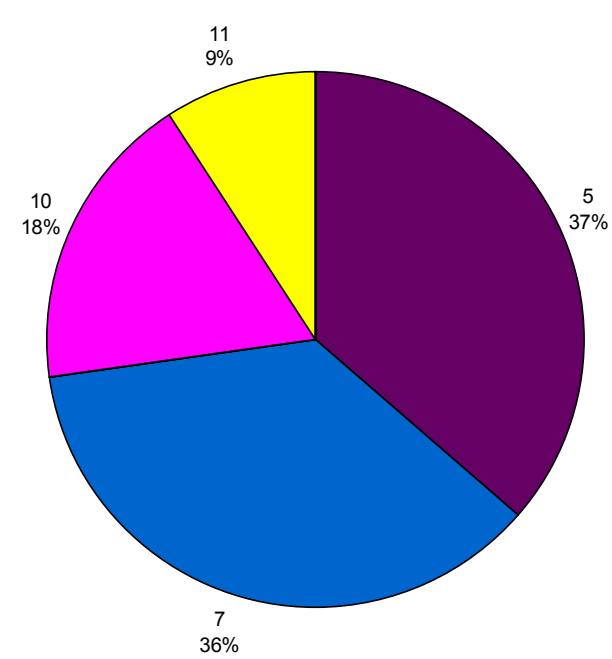

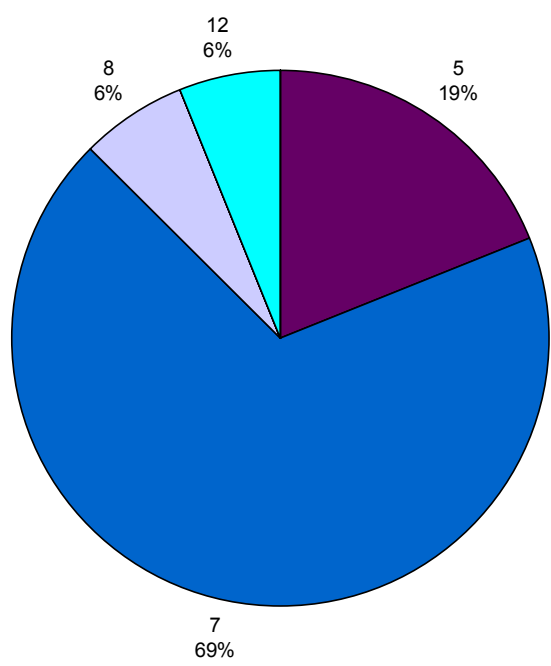

6, 12 e 24 hora

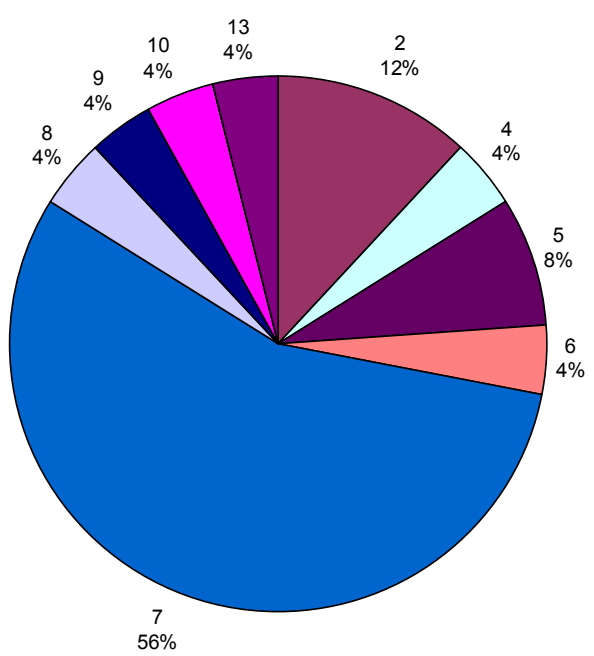

Figura 24 - Diferentes classes gênicas dos clones induzidos em três tempos do experimento. Esta classificação foi feita de acordo com o banco de dados do SUCEST, e estão representadas da seguinte forma: ${ }^{1}$ crescimento/desenvolvimento, ${ }^{2}$ met. proteína, ${ }^{3}$ met. RNA, ${ }^{4}$ proteína de armazenamento ${ }^{5}$ estresse, ${ }^{6}$ transporte, ${ }^{7} \mathrm{ND}$, ${ }^{8}$ bioenergética, ${ }^{9}$ transdução de sinal, ${ }^{10}$ dinâmica celular, ${ }^{11}$ met. lipídeos, ${ }^{12}$ elementos móveis, ${ }^{13}$ met. nucleotídeos 
Estavam presentes nos tempos de 0.5, 12 e 24 horas quatro classes gênicas, a de resposta ao estresse, de dinâmica celular, de metabolismo de lipídios e de função não determinada (ND). Nestes tempos, a classe contendo genes responsivos à diferentes condições de estresse mostrou-se mais representativa, com 4 genes identificados, $36 \%$ dos induzidos.

Foram encontradas nove classes gênicas nos tempos de 6, $12 \mathrm{e}$ 24 horas: metabolismo de proteínas, proteína de armazenamento, resposta ao estresse, transporte, bioenergética, transdução de sinal, dinâmica celular, metabolismo de nucleotídeos e função não determinada (ND). A classe com maior número de genes foi a de metabolismo de proteínas, contendo 3 genes que representam $12 \%$ dos genes induzidos.

Através da análise dos gráficos presentes na Figura 24, representando os genes induzidos em três tempos do experimento, pôde ser observado que as classes de crescimento/desenvolvimento e de metabolismo de RNA somente foram induzidas nos tempos de $0.5,6$ e 12 horas. O grupo dos elementos móveis aparece induzido somente nos tempos de $0.5,6$ e 24 horas, enquanto as classes de metabolismo de proteínas, de proteínas de armazenamento e de metabolismo de nucleotídeos estão presentes nos tempos de 6,12 e 24 horas.

Vinte e um genes foram induzidos nos quatro tempos do experimento. Estes clones estão listados no APÊNDICE 12, onde estão descritos também seus respectivos produtos gênicos. A Figura 25 apresenta a classificação funcional dos mesmos, os quais foram agrupados em sete classes: metabolismo de RNA, resposta ao estresse, transporte, transdução de sinal, dinâmica celular, metabolismo de DNA e genes de função não determinada (ND). Neste grupo, as classes de transporte e de dinâmica celular foram as mais representativas, correspondendo a dois genes identificados em cada classe, equivalentes a $19 \%$ dos genes conhecidos neste padrão. 


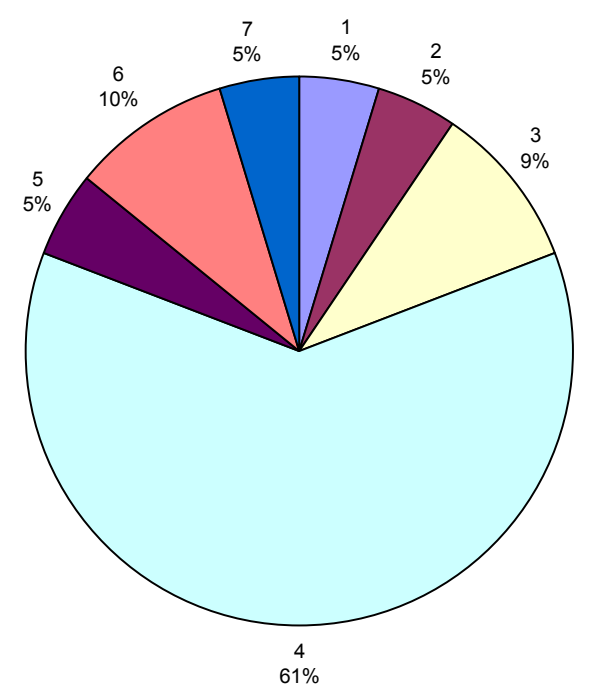

Figura 25 - Diferentes classes gênicas dos clones induzidos nos quatro tempos de experimentação. Esta classificação está representada da seguinte forma: ${ }^{1}$ met. RNA, ${ }^{2}$ resposta ao estresse, ${ }^{3}$ transporte, ${ }^{4} \mathrm{ND},{ }^{5}$ transdução de sinal, ${ }^{6}$ dinâmica celular, ${ }^{7}$ met. DNA

Seguindo os mesmos procedimentos de análise realizados para a variedade susceptível, na Tabela 8 estão resumidamente apresentados os resultados obtidos para a variedade tolerante. A partir destes dados foi possível observar que o tempo mais significativo em relação à indução de genes foi o de 6 horas, correspondendo à 390 genes analisados. Os demais tempos de experimentação $(0.5,12$ e 24 horas) não tiveram uma diferença significativa quanto ao número de genes induzidos, apresentando, respectivamente, 281, 287 e 321 genes induzidos em relação às plantas controle. 
Tabela 8. Número de genes induzidos para cada classe funcional apresentada na variedade tolerante

\begin{tabular}{|c|c|c|c|c|c|c|c|c|c|c|c|c|c|c|c|c|}
\hline \multirow{4}{*}{$\begin{array}{c}\text { CATEGORIAS } \\
\text { GÊNICAS }\end{array}$} & \multirow{2}{*}{\multicolumn{10}{|c|}{ TEMPOS DE INDUÇÃO }} & \multirow{2}{*}{\multicolumn{3}{|c|}{$0.5 \mathrm{~h} 0.5 \mathrm{~h} 0.5 \mathrm{~h}$}} & \multicolumn{3}{|c|}{$0.5 \mathrm{~h}$} \\
\hline & & & & & & & & & & & & & & $6 \mathrm{~h}$ & $6 \mathrm{~h}$ & \\
\hline & & & & & $6 \mathrm{~h}$ & $0.5 \mathrm{~h}$ & $6 \mathrm{~h}$ & $0.5 \mathrm{~h}$ & $12 \mathrm{~h}$ & $0.5 \mathrm{~h}$ & $6 \mathrm{~h}$ & $6 \mathrm{~h}$ & $12 \mathrm{~h}$ & $12 \mathrm{~h}$ & $12 \mathrm{~h}$ & \\
\hline & $0.5 \mathrm{~h}$ & $6 \mathrm{~h}$ & $12 \mathrm{~h}$ & $24 \mathrm{~h}$ & $24 \mathrm{~h}$ & $12 \mathrm{~h}$ & $12 \mathrm{~h}$ & $6 \mathrm{~h}$ & $24 \mathrm{~h}$ & $24 \mathrm{~h}$ & $12 \mathrm{~h}$ & $24 \mathrm{~h}$ & $24 \mathrm{~h}$ & $24 \mathrm{~h}$ & $24 \mathrm{~h}$ & TOTAL \\
\hline met. aa. & 3 & 2 & 2 & & & 1 & & 2 & & 1 & & & & & & 11 \\
\hline crescimento/desenvolvimento & 1 & 6 & 2 & 4 & 1 & & 3 & 1 & 2 & & 1 & & & & & 21 \\
\hline met. proteína & 5 & 6 & 7 & 8 & 2 & 2 & 3 & 2 & 1 & 2 & & & & 3 & & 41 \\
\hline met. RNA & 1 & 1 & 1 & 2 & 1 & 3 & 2 & & 2 & 1 & 1 & & & & 1 & 16 \\
\hline met. $2^{\text {ário }}$ & 4 & & 2 & 3 & & 1 & 1 & 1 & 1 & 2 & & & & & & 15 \\
\hline proteína de armazenamento & & & & 1 & & & & & & & & & & 1 & & 2 \\
\hline estresse & 8 & 5 & 2 & 7 & 7 & 3 & 3 & 3 & 2 & 2 & & 3 & 4 & 2 & 1 & 52 \\
\hline transporte & 1 & 2 & 2 & 2 & 3 & 1 & 1 & & 4 & 1 & 1 & & & 1 & 2 & 21 \\
\hline bioenergética & 5 & 8 & 2 & 4 & 4 & 2 & & 1 & 3 & 1 & 2 & 1 & & 1 & & 34 \\
\hline transdução de sinal & 5 & 5 & 1 & 8 & 4 & 3 & 3 & 1 & 4 & 4 & 1 & & & 1 & 1 & 41 \\
\hline dinâmica celular & 7 & 10 & 1 & 6 & 2 & 4 & 4 & 3 & 3 & 1 & 1 & & 2 & 1 & 2 & 47 \\
\hline met. DNA & 1 & 1 & 2 & & 1 & & & & & & & & & & 1 & 6 \\
\hline met. lipídeos & & 3 & 2 & 1 & 1 & & 1 & 1 & 2 & & 1 & & 1 & & & 13 \\
\hline elementos móveis & 1 & 2 & & & 3 & & 1 & & & & & 1 & & & & 8 \\
\hline met. N, S e P & & 1 & & 1 & & & & & & & & & & & & 2 \\
\hline met. nucleotídeos & & & & 1 & & & 1 & 1 & & & & & & 1 & & 4 \\
\hline ND & 44 & 98 & 41 & 64 & 26 & 24 & 33 & 33 & 21 & 21 & 10 & 11 & 4 & 14 & 13 & 457 \\
\hline TOTAL & 86 & 150 & 67 & 112 & 55 & 44 & 56 & 49 & 45 & 36 & 18 & 16 & 11 & 25 & 21 & 791 \\
\hline
\end{tabular}

Dos 334 genes identificados, as classes menos representadas foram as de proteína de armazenamento e de metabolismo de nitrogênio, sulfato e fosfato, com 2 genes identificados em cada. Com 52 genes induzidos, a classe de resposta ao estresse foi a que apresentou o maior número de genes identificados.

De acordo com a Tabela 8, é possível observar que a classe de proteína de armazenamento não teve genes induzidos no tempo de 0.5 hora. Já a classe de metabolismo de nitrogênio, sulfato e fosfato não apresentou genes identificados nos tempos de 0.5 e 12 horas do experimento.

A classe de proteínas de armazenamento foi representada por 2 genes: a vegetative storage protein, induzida no tempo de 24 horas, e a patatin, identificada nos tempos de 6, 12 e 24 horas. Este último gene também foi induzido na variedade susceptível, nos tempos de 6 e 24 horas. Estas 
glicoproteínas são conhecidas por sua atividade de fosfolipases (Wittenbach, 1983), catalisando a hidrólise dos fosfolipídios que liberam ácidos graxos envolvidos em vários processos biológicos, incluindo o reparo da membrana plasmática, a transdução de sinais e o mecanismo de defesa em resposta à ferimentos mecânicos, herbívoros e também contra patógenos. As proteínas de armazenamento das plantas podem ser classificadas em seed storage protein (SSPS) e vegetative storage protein (VSPS). SSPs são proteínas que se acumulam nas sementes durante os estágios de seu desenvolvimento, sendo utilizadas como fonte nutritiva na plântula. Já as VSPS são proteínas que se acumulam em tecidos vegetativos, tais como, hipocótilos, folhas, flores, hastes e, dependendo da espécie, em tubérculos, podendo servir como um reservatório de aminoácidos para o uso em diferentes fases do crescimento e desenvolvimento. As proteínas VSPS estão relacionadas à adaptação da planta quando em condições de estresse (Noquet et al., 2001; Meuriot et al., 2004). De acordo com Reymond et al. (2000), as plantas induzem um grande número genes quando em presença de insetos herbívoros,respondendo assim, ao estresse do ferimento. Alguns destes genes induzidos participam da via octadecanóide de defesa, que culmina na biossíntese do jasmonato (JA). Howe et al. (1996) e McConn et al. (1997) relatam o JA como um componente chave da resistência da planta aos insetos, pois o ácido jasmônico é a substância que percebe a ferida e induz a expressão de genes de defesa. Berger (2002) relatou inibidores de protease (PIs) e VSP como proteínas reguladas após a síntese de JA nas plantas. Em soja, existem duas glicoproteínas vacuolares, VSPa e $V S P \beta$, que se acumulam nas folhas em níveis elevados após a remoção de ramos (Mason \& Mullet, 1990). Segundo Creelman et al. (1992) um aumento nos níveis de JA e de MeJA é seguido de um acúmulo nos níveis de transcritos dos genes vsp em soja. Este mesmo autor relata que inibidores da lipoxigenase (LOX), uma enzima envolvida na biossíntese de JA, também inibe a produção de VSP. Em Arabidopsis thaliana há dois genes homólogos aos que codificam VSPs em soja, vsp1 e vsp2, os quais também são induzidos por ácido 
jasmônico (Benedetti et al., 1995) e ferimento mecânico (Utsugi et al. 1998), similar ao que ocorre com VSPs de soja. Segundo Staswick (1994), a indução de VSPS parece ser um mecanismo da adaptação ao estresse, promovendo um seqüestro de recursos da planta durante os períodos de herbivoria. Quando as circunstâncias se tornam favoráveis, VSPS assim como outros recursos tornamse disponíveis para o crescimento e reprodução das plantas. Strauss \& Agrawal (1999) relacionaram VSPS com o mecanismo indireto de defesa, sendo um provável constituinte da tolerância das plantas aos insetos herbívoros. No entanto, a função de defesa direta não pode ser excluída porque nenhum estudo da atividade antinutritiva das VSPs foram testadas. Estas VSPS também foram relatadas em alfafa, batata, chicória e em algumas leguminosas (Meyer et al., 1984; Ourry et al., 2001; Rossato et al., 2002).

Em relação aos genes da classe de metabolismo de nitrogênio, sulfato e fosfato, foi induzido no tempo de 6 horas o gene da proteína DsPTP1, e no tempo de 24 horas o gene da MtN3. A proteína DsPTP1 também foi induzida na variedade susceptível, porém no tempo de 24 horas. Em Arabidopsis, esta proteína, dual specificity protein phosphatase 1- DsPTP1, é capaz de hidrolisar resíduos de fosfoserina/treonina e fosfotirosina dos substratos celulares (Yoo et al., 2004). Segundo estes autores esta proteína é $\mathrm{Ca}^{2+}$ dependente, pois o aumento nas concentrações de $\mathrm{Ca}^{2+}$ levou a um aumento na atividade bioquímica destas DsPTP1, indicando que a calmodulina pode diferencialmente regular a atividade das fosfatases, atuando na via de fosforilação e também na de defosforilação, dependendo do tipo de substrato. Neste trabalho, as DsPTP1 podem estar envolvidas na via de degradação de proteínas, uma vez que houve um grande número de transcritos a partir do tempo de 6 horas. Sobre a proteína MtN3, também encontrada induzida na variedade susceptível no tempo de 0.5 hora, Asamizu et al. (2000) relataram a presença de ESTs desta proteína em plantas jovens da leguminosa Lotus japonicus. Segundo os autores, as seqüências expressas tinham grande similaridade com genes nódulo-específico de Medicago truncatula (Gamas et 
al., 1996). Seki et al. (2002) reportaram que as proteínas MtN3 foram induzidas quando plantas de Arabidopsis foram tratadas com ácido abscísico (ABA). Além das evidências de que o $A B A$ está relacionado à salinidade e aos estresses hídrico e térmico (Birkenmeier \& Ryan, 1998), este fitorregulador também pode estar envolvido na indução de $\mathrm{NO}^{3-}$ e $\mathrm{PO}_{4}{ }^{3-}$ (Arteca, 1996; Oliveira et al., 2002). Análise de microarranjos de DNA, realizada por Vlieghe et al. (2003), indicaram que quando o metabolismo de nitrogênio é alterado em plantas transgênicas de Arabidopsis, a expressão de genes homólogos aos do nódulo de fixação de nitrogênio em Medicago sativa (MtN3 e nodulin) também é alterada, apresentando uma relação direta com a assimilação de nitrogênio pela planta.

A partir dos resultados apresentados na Tabela 8, observou-se que as classes gênicas de metabolismo de RNA, de estresse, de transporte, de transdução de sinal, de dinâmica celular e de metabolismo de DNA foram algumas das classes induzidas em todos os tempos do experimento. 


\subsection{Comparação Entre Variedade Susceptível e Tolerante}

Para mensurar quão diferentes são as variedades susceptível (SP80-3280) e tolerante (SP81-3250) de cana-de-açúcar, foi realizado o estudo comparativo dos genes induzidos em resposta à herbivoria.

Em uma análise geral, foram descritas dezessete diferentes classes gênicas funcionais induzidas para estas variedades (Figura 27). De acordo com as classes descritas, pode-se constatar que a classe de genes desconhecidos representa cerca de $60 \%$ dos genes induzidos neste trabalho. Segundo Vettore et al. (2003), este grupo de genes (unknow protein, hypothetical protein, putative protein e unable to classify) contém $41,7 \%$ dos transcritos de cana-de-açúcar. Ainda de acordo com a base de dados de SUCEST (Vettore et al., 2003), as cinco classes mais expressas nas duas variedades foram: metabolismo de proteínas, resposta ao estresse, bioenergética, transdução de sinal e de dinâmica celular.

Foi realizado um processo de normalização das sondas para a seleção de genes induzidos nas duas variedades, no qual 522 clones foram selecionados por estarem presentes em ambas. Destes, 304 estavam induzidos na variedade susceptível e 296 na variedade tolerante. Observou-se que 192 clones estavam induzidos nas duas variedades (APÊNDICE 13), não necessariamente induzidos nos mesmos tempos de avaliação dos tratamentos. 

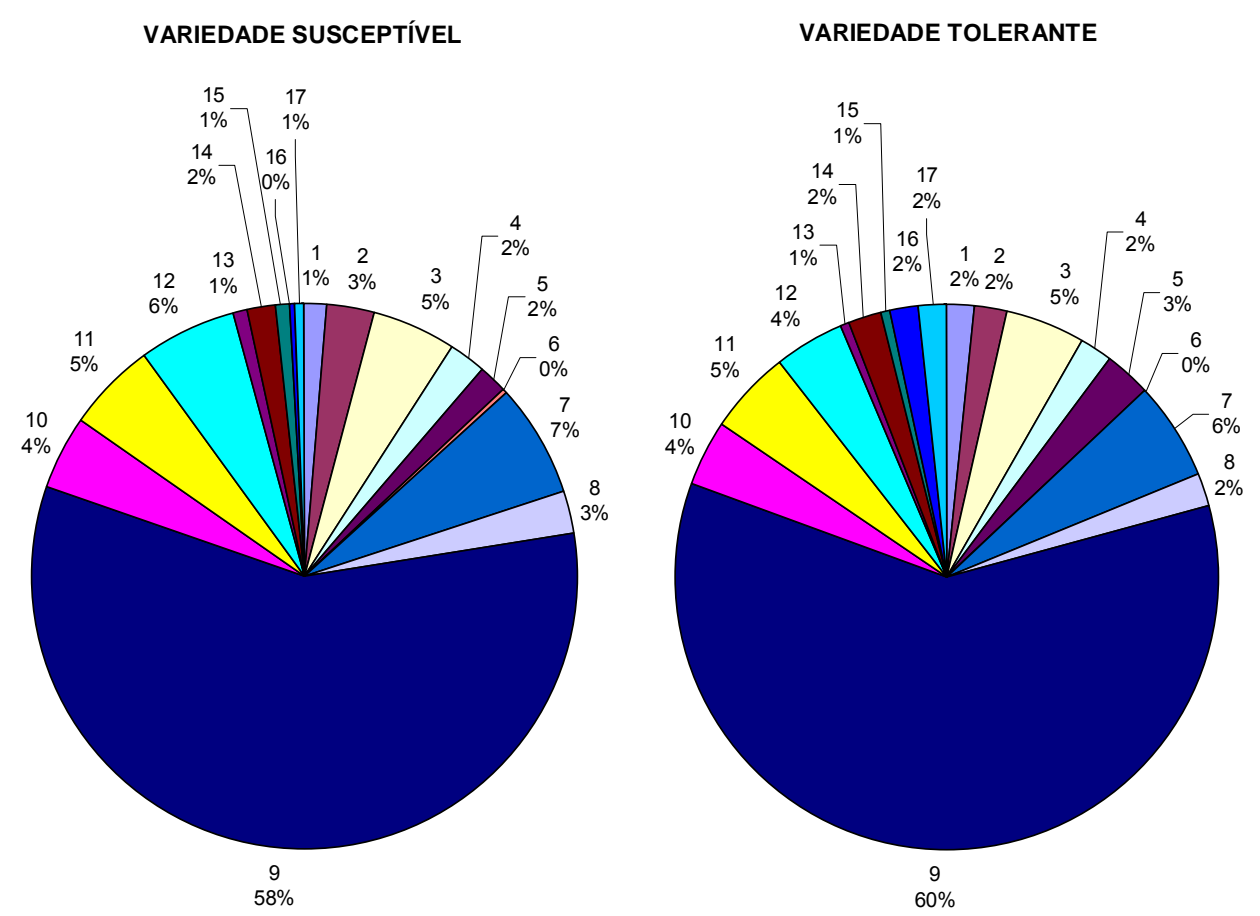

Figura 27 - Diferentes classes gênicas para as duas variedades de cana. Este agrupamento foi realizado de acordo com o banco de dados do SUCEST, e estão representados da seguinte forma: ${ }^{1}$ met. aa., ${ }^{2}$ crescimento/desenvolvimento, ${ }^{3}$ met. proteína, ${ }^{4}$ met. RNA, ${ }^{5}$ met. $2^{2 \text { ário }},{ }^{6}$ proteína de armazenamento, ${ }^{7}$ estresse, ${ }^{8}$ transporte, ${ }^{9} \mathrm{ND}$, ${ }^{10}$ bioenergética, ${ }^{11}$ transdução de sinal, ${ }^{12}$ dinâmica celular, ${ }^{13}$ met. DNA, ${ }^{14}$ met. lipídeos, ${ }^{15}$ elementos móveis, ${ }^{16}$ met. $\mathrm{N}$, S e P, ${ }^{17}$ met. nucleotídeos 


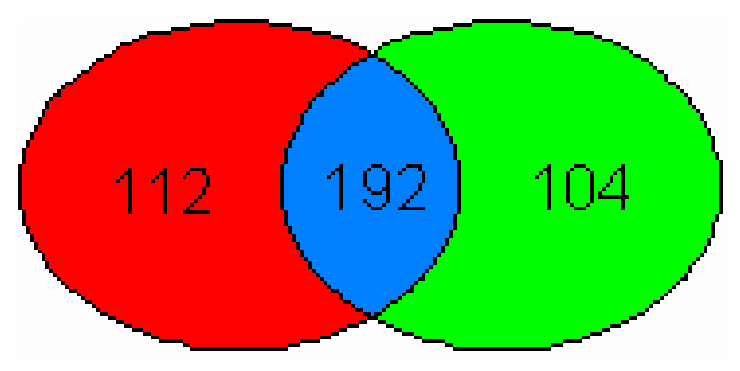

\section{SUSCEPTIVEL TOLERANTE}

Figura 28 - Número de genes induzidos após o processo de normalização para as duas variedades de cana-de-açúcar

A Figura 28 representa os genes induzidos nas duas variedades. Dos 522 clones selecionados, 408 apresentaram indução gênica 2 vezes maiores ou menores (induzidos ou reprimidos) em relação ao log da razão entre valores de leitura dos tratamentos com lagarta e os valores de leitura obtidos nos tratamentos das plantas controle. Pôde-se notar que a maioria dos genes induzidos ocorre nas duas variedades (representados em azul na região de congruência dos círculos na Figura 28). O número apresentado na região em vermelho, da mesma figura, refere-se aos genes induzidos somente na variedade susceptível, enquanto o apresentado na região verde, somente os induzidos na variedade tolerante.

Quanto ao tempo de indução de genes responsivos à herbivoria, observou-se que no tempo de 6 horas um maior número de genes estavam induzidos para as duas variedades, 179 para a variedade susceptível e 255 na variedade tolerante. Como dito anteriormente, as lagartas de $D$. saccharalis iniciaram sua alimentação nas plantas de cana-de-açúcar depois de uma hora da montagem do experimento, apresentando alimentação contínua ao longo dos tempos de tratamento. Deste modo, os genes identificados no tempo de 6 
horas são possíveis genes relacionados à defesa contra herbivoria. Estes dados estão de acordo com o reportado por Ryan (2000), o qual apresentou uma comparação relativa de classes gênicas induzidas ao longo do tempo e o diferencial de mRNAs codificadores de proteínas de defesa em plantas de tomate submetidas ao ferimento mecânico. Assim, o tempo de 6 horas foi analisado para o estudo de potenciais genes relacionados à resistência de plantas aos insetos. Devido à importância deste tempo, os genes inibidos nos tratamentos com lagarta também foram avaliados. Na variedade susceptível 241 genes estavam inibidos, enquanto na tolerante foram 293.

Os genes induzidos e inibidos das duas variedades foram classificados de acordo com o banco de dados do SUCEST e estão representados na Figura 29. Observa-se que o maior número de genes, para ambas variedades, apresenta função não determinada (ND). Nota-se que a variedade tolerante apresentou um maior número de genes envolvidos em dinâmica celular, podendo este ser um mecanismo genético para a resistência de plantas às pragas. 


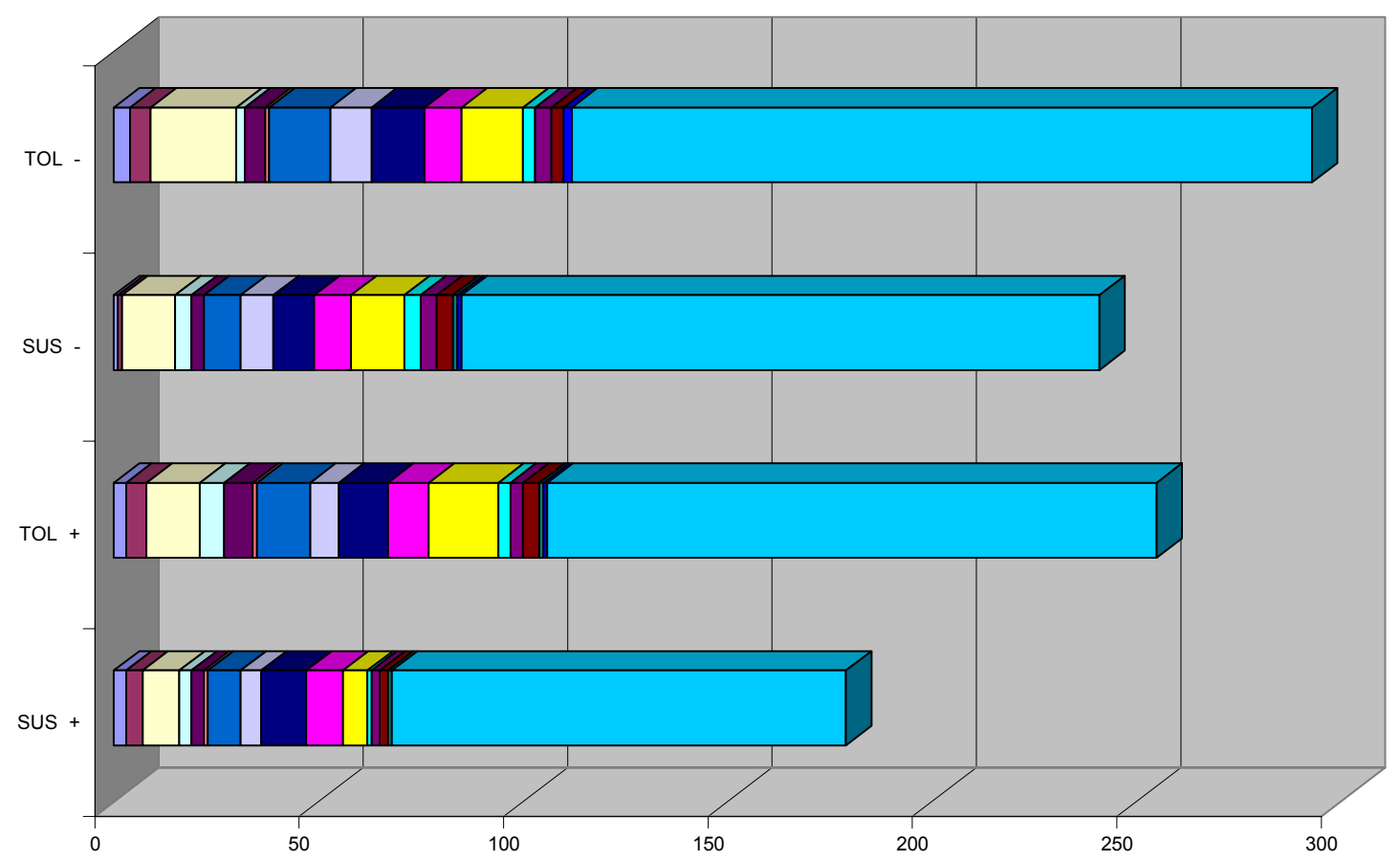

$\square$ met. aa.

$\square$ met. 2ário

bioenergética

$\square$ met. Lipídeos $\square N D$ $\square$ crescimento/desenvolvimento
$\square$ proteína de armazenamento
$\square$ transdução de sinal
$\square$ elementos móveis $\square$ met. Proteína

$\square$ estresse

$\square$ dinâmica celular

$\square$ met. N, S e P $\square$ met. RNA

$\square$ transporte

$\square$ met. DNA

- met. nucleotídeos

Figura 29 - Comparação entre número de genes e classes gênicas induzidas $(+)$ ou reprimidas (-) nas variedades susceptível (SUS) e tolerante (TOL) no tempo de 6 horas de avaliação do experimento 
A seguir, nas Tabelas 11 e 12, estão alguns genes induzidos nas variedades susceptível e tolerante respectivamente. Em relação aos genes induzidos, notou-se um maior número de genes das classes de metabolismo de proteínas, de metabolismo de RNA, de metabolismo secundário, de resposta ao estresse, de transporte, de dinâmica celular, de metabolismo de DNA, de elementos móveis e de metabolismo de nucleotídeos na variedade tolerante (Tabela 12), não existindo nenhuma classe sobressalente na variedade susceptível (Tabela 11).

Analisando os genes relacionados ao estresse encontrados induzidos na variedade tolerante (Tabela 12) podemos correlacionar com os dados de Cheong et al. (2002). Segundo trabalho realizado por este grupo, utilizando plantas de Arabidopsis, foi relatado que um grande número de genes responsivos ao ferimento mecânico codificam proteínas também envolvidas no mecanismo de defesa contra patógenos. Estes resultados também estão de acordo com os trabalhos de Arimura et al. (2000b) e Reymond et al. (2000), que utilizaram ESTs para a busca de genes responsivos à herbivoria em plantas de feijão e em Arabidopsis respectivamente. Segundo Lorenzo et al. (2003), alguns destes transcritos também são induzidos por aplicação exógena de etileno e jasmonato, corroborando os resultados aqui apresentados. 
Tabela 11. Genes induzidos na variedade susceptível

\begin{tabular}{|c|c|c|c|c|c|}
\hline \multirow[t]{2}{*}{ Descrição } & \multirow[t]{2}{*}{ Longest } & \multicolumn{4}{|c|}{ Log (Razão) } \\
\hline & & $0.5 \mathrm{~h}$ & $6 \mathrm{~h}$ & $12 \mathrm{~h}$ & $24 \mathrm{~h}$ \\
\hline \multicolumn{6}{|l|}{ Bioenergética } \\
\hline galactokinase GAL1 & SCQGST3123F12 & 0,20 & 3,23 & 0,65 & 0,20 \\
\hline IN2-2 protein & SCACLR2014G02 & 0,20 & 3,47 & $-0,53$ & 3,12 \\
\hline \multicolumn{6}{|l|}{ Crescimento/Desenvolvimento } \\
\hline homeodomain transcription factor KNAT6 & SCBGLR1100A10 & 0,45 & $-3,28$ & 2,72 & 3,08 \\
\hline putative homeodomain protein & SCCCLR1C04A01 & $-0,18$ & 3,45 & 0,12 & $-0,06$ \\
\hline \multicolumn{6}{|l|}{ Dinâmica Celular } \\
\hline cyclin D2.1 protein & SCSFST1064C07 & 0,41 & 1,12 & $-0,25$ & 3,01 \\
\hline histone H2A.4 & SCJLLR1105A01 & 0,25 & 3,27 & $-0,04$ & $-1,20$ \\
\hline myb-related protein 1 & SCEQLR1094G05 & 0,18 & $-0,11$ & 1,20 & 3,02 \\
\hline \multicolumn{6}{|l|}{ Elementos Móveis } \\
\hline high mobility group I/Y-2 & SCEQLR1094C08 & 0,48 & 2,71 & 0,34 & $-2,86$ \\
\hline putative reverse transcriptase & SCQSST3115C01 & 2,78 & 2,43 & $-0,83$ & 0,21 \\
\hline \multicolumn{6}{|l|}{ Estresse } \\
\hline abrin-a & SCEZAD1078B05 & 0,09 & $-0,30$ & 2,87 & $-0,38$ \\
\hline acyltransferase homolog & SCCCLR2002D06 & 2,74 & 0,66 & $-0,41$ & 2,54 \\
\hline Barwin, Basic Barley Seed Protein & SCBGRT1049B06 & 0,34 & $-2,73$ & 2,82 & 0,32 \\
\hline DnaJ-like protein & SCJLLR1105F12 & 2,44 & 2,67 & 0,00 & 0,67 \\
\hline glutathione peroxidase & SCSGST1071C07 & 0,88 & 3,43 & $-0,56$ & $-0,60$ \\
\hline glutathione S-transferase GST 17 & SCACLR1130D06 & $-1,25$ & 3,20 & 0,21 & 1,15 \\
\hline metallothionein-like protein type 2 & SCBGST3103A07 & 0,34 & 2,94 & $-2,56$ & 1,58 \\
\hline MLA6 protein & SCACLR1126F06 & 0,08 & 0,28 & 0,57 & 3,12 \\
\hline peroxidase 4 precursor & SCBGST3106C01 & 3,17 & $-2,43$ & 1,84 & 2,83 \\
\hline probable integral membrane protein & SCRFFL8037C01 & 0,75 & 2,58 & 0,16 & 0,27 \\
\hline putative aphid transmission factor & SCCCLR1C06A09 & 0,33 & 2,87 & 3,23 & 0,87 \\
\hline putative wound-induced protein & SCCCLR2C02A01 & $-0,13$ & 2,70 & $-3,09$ & $-0,48$ \\
\hline receptor protein kinase & SCRLAD1140C02 & 0,35 & 2,65 & 0,93 & $-0,59$ \\
\hline superoxide dismutase & SCQGLR1088H10 & $-0,03$ & $-3,45$ & 2,45 & $-2,66$ \\
\hline \multicolumn{6}{|l|}{ Metabolismo de aminoácidos } \\
\hline adenylsulfate kinase 1 & SCBGST3108C02 & 0,81 & $-3,41$ & 0,00 & 2,67 \\
\hline aspartame aminotransferase & SCSGLV1009G12 & 2,33 & 0,09 & 2,21 & $-0,59$ \\
\hline EC 5.3.1.16 & SCSFST3077F12 & $-0,60$ & 2,48 & 2,13 & 0,64 \\
\hline phosohoserine aminotransferase & SCBGST3110G10 & $-0,13$ & 3,60 & 0,43 & 0,87 \\
\hline \multicolumn{6}{|l|}{ Metabolismo de Lipídeos } \\
\hline AMP-binding protein & SCVPST1063F10 & 0,20 & 1,88 & 3,23 & 2,91 \\
\hline HMG-CoA synthase & SCSBST3098E12 & 2,65 & $-2,22$ & 3,07 & 0,41 \\
\hline Oxalyl-CoA decarboxylase & SCSBST3098C11 & $-0,22$ & 2,76 & $-1,94$ & 0,00 \\
\hline w-3 fatty acid desaturase & SCSFST3075A09 & 0,16 & 2,38 & $-0,90$ & $-0,15$ \\
\hline \multicolumn{6}{|l|}{ Metabolismo de Nitrogênio, Enxofre e Fósforo } \\
\hline DsPTP1 protein & SCUTST3087E08 & 2,35 & $-0,11$ & 0,26 & 3,01 \\
\hline
\end{tabular}


Tabela 11. Genes induzidos na variedade susceptível

\begin{tabular}{|c|c|c|c|c|c|}
\hline \multicolumn{6}{|l|}{ Metabolismo de Proteína } \\
\hline AMP-binding protein & SCVPST1063F10 & 0,20 & 1,88 & 3,23 & 2,91 \\
\hline HMG-CoA synthase & SCSBST3098E12 & 2,65 & $-2,22$ & 3,07 & 0,41 \\
\hline \multicolumn{6}{|l|}{ Metabolismo de RNA } \\
\hline RNA-binding protein & SCCCST3001H10 & 0,04 & 3,58 & 2,29 & 3,23 \\
\hline putative transcription factor & SCSGST1069D04 & 2,53 & 0,38 & 3,41 & 0,83 \\
\hline \multicolumn{6}{|l|}{ Metabolismo Secundário } \\
\hline flavonol 3-O-glucosyltransferase-like protein & SCJFST1048H08 & 2,77 & 0,00 & 0,34 & $-0,42$ \\
\hline isoplavone reductase & SCSBST3096H07 & 0,51 & 0,90 & 2,49 & 1,91 \\
\hline putative UDP-glucose glucosyltransferase & SCUTLR2023E12 & $-0,85$ & 2,80 & 1,97 & 0,00 \\
\hline \multicolumn{6}{|l|}{ Não Determinados (ND) } \\
\hline ND & SCQSST3116C10 & 0,00 & 0,47 & $-0,48$ & 3,30 \\
\hline ND & SCSGST1068C11 & 0,51 & 3,30 & 0,08 & 0,12 \\
\hline ND & SCCCST3004H05 & $-0,18$ & $-0,26$ & 2,73 & 3,28 \\
\hline ND & SCMCST1049B12 & 2,25 & 1,37 & 0,51 & 3,27 \\
\hline \multicolumn{6}{|l|}{ Proteína de Armazenamento } \\
\hline patatin & SCQSST1040G01 & $-0,40$ & 2,23 & 0,01 & 2,11 \\
\hline \multicolumn{6}{|l|}{ Transdução de Sinal } \\
\hline transcription factor TINY & SCUTST3086B02 & 2,90 & 3,31 & $-0,09$ & $-0,17$ \\
\hline protein phosphatase $2 \mathrm{~A}$ regulatory subunit $\mathrm{B}^{\prime}$ & SCJFST1047C03 & 0,33 & 3,31 & 0,32 & $-0,87$ \\
\hline calcium-dependent protein kinase & SCUTST3086B04 & $-0,01$ & 3,16 & $-1,23$ & 1,63 \\
\hline ARF2 & SCBGLR1114G12 & 2,15 & 3,10 & 2,43 & 0,59 \\
\hline \multicolumn{6}{|l|}{ Transporte } \\
\hline mitochondrial solute carrier protein & SCMCLR1125A10 & $-0,21$ & 3,40 & 0,31 & $-0,18$ \\
\hline PPR-repeat protein & SCCCLR1C01G12 & 0,36 & 3,14 & $-0,02$ & 0,42 \\
\hline
\end{tabular}


Tabela 12. Genes induzidos na variedade tolerante

\begin{tabular}{|c|c|c|c|c|c|}
\hline \multirow[t]{2}{*}{ Descrição } & \multirow[t]{2}{*}{ Longest } & \multicolumn{4}{|c|}{ Log (Razão) } \\
\hline & & $0.5 \mathrm{~h}$ & $6 \mathrm{~h}$ & $12 \mathrm{~h}$ & $24 \mathrm{~h}$ \\
\hline \multicolumn{6}{|l|}{ Bioenergética } \\
\hline uncoupling protein mitochonrial & SCVPRZ3025F04 & 3,29 & 0,05 & 1,34 & 0,24 \\
\hline carbonate dehydratase & SCBGST3104F06 & $-0,22$ & $-0,60$ & $-0,15$ & 3,26 \\
\hline putative anthocyanin 5-O-glucosyltransferase & SCSGLV1004A12 & $-0,94$ & $-1,44$ & 1,53 & 3,03 \\
\hline \multicolumn{6}{|l|}{ Crescimento/Desenvolvimento } \\
\hline homeodomain transcription factor KNAT6 & SCBGLR1100A10 & 0,07 & $-1,59$ & 0,05 & 3,19 \\
\hline \multicolumn{6}{|l|}{ Dinâmica Celular } \\
\hline probable transcription factor & SCCCFL5065C01 & 3,19 & $-0,24$ & 1,98 & $-2,86$ \\
\hline glucan endo-1,3-beta-glucosidase precursor & SCSFSB1102C09 & 0,69 & 0,25 & 3,18 & 0,46 \\
\hline chitinase & SCQGHR1013D01 & 0,10 & 0,47 & 0,08 & 3,08 \\
\hline \multicolumn{6}{|l|}{ Elementos Móveis } \\
\hline putative gag/pol polyprotein & SCSGRT2061C02 & 3,14 & 2,81 & 0,00 & 0,96 \\
\hline retroelement pol polyprotein-like & SCVPST1063C05 & $-0,14$ & 1,02 & 2,15 & $-2,83$ \\
\hline \multicolumn{6}{|l|}{ Estresse } \\
\hline putative phloem-specific lectin & SCACLR2007D05 & 0,10 & $-0,65$ & $-0,16$ & 3,48 \\
\hline pathogenesis-related protein & SCQGST3125F02 & 2,05 & 0,97 & 2,98 & 3,29 \\
\hline putative aphid transmission factor & SCCCLR1C06A09 & $-0,74$ & 1,47 & $-1,35$ & 3,17 \\
\hline polygalacturonase inhibitor & SCSGLV1007G11 & 3,16 & 0,10 & $-0,26$ & 0,32 \\
\hline chitinase III C10150 & SCJLRT1015B03 & 3,13 & $-0,88$ & 2,53 & 0,59 \\
\hline disease resistance protein RPM1 & SCUTST3130D10 & $-0,98$ & 1,38 & 0,26 & 3,13 \\
\hline cysteine proteinase inhibitor & SCCCFL3003E06 & 3,11 & $-0,12$ & 2,47 & 1,65 \\
\hline extensin homolog T9E8.80 & SCSGST1068A02 & $-0,60$ & 1,15 & $-0,09$ & 3,11 \\
\hline drought-induced protein Di19 & SCSGFL4189F01 & 0,34 & 0,62 & 2,77 & 0,84 \\
\hline putative wound-induced protein & SCCCLR2C02A01 & 0,70 & $-2,08$ & 2,38 & 0,02 \\
\hline wound-induced protein & SCMCLR1122D11 & $-0,17$ & $-2,06$ & $-0,46$ & 2,96 \\
\hline zinc finger protein & SCQGST3125E10 & 2,26 & 0,00 & 2,40 & $-0,62$ \\
\hline heat shock protein 70 & SCRFST1041E06 & 2,35 & $-0,58$ & 2,64 & 2,97 \\
\hline peroxidase 4 precursor & SCBGST3106C01 & 0,47 & 1,58 & 2,40 & 0,97 \\
\hline metallothionein-like protein type 2 & SCBGST3103A07 & $-0,78$ & 0,50 & $-0,51$ & 2,41 \\
\hline superoxide dismutase & SCQGLR1088H10 & 0,30 & $-0,26$ & 2,04 & $-0,54$ \\
\hline laccase & SCUTST3084C11 & $-3,21$ & 2,99 & 0,30 & 2,78 \\
\hline Barwin, Basic Barley Seed Protein & SCRFRT3058D04 & 1,07 & $-0,25$ & 2,02 & 0,74 \\
\hline disease resistance gene homolog $9 \mathrm{~N}$ & SCMCST1052E09 & $-0,16$ & $-0,30$ & 2,05 & 2,39 \\
\hline MLA6 protein & SCCCST3002D02 & $-0,52$ & 0,83 & 2,39 & 0,74 \\
\hline probable wound-induced protein & SCUTLR2008H11 & 2,17 & 0,92 & $-0,82$ & 1,64 \\
\hline serine/threonine-specific receptor protein kinase & SCRFST1042D08 & $-0,30$ & 1,37 & 2,17 & $-0,04$ \\
\hline 1,3-beta-glucanase PRm 6b & SCQGRT1042E04 & 1,06 & $-0,66$ & $-0,27$ & 2,70 \\
\hline germin-like protein 5 & SCCCLR2C02D04 & $-2,05$ & $-1,47$ & $-3,25$ & 2,66 \\
\hline \multicolumn{6}{|l|}{ Metabolismo de Lipídeos } \\
\hline allene oxide synthase & SCVPAM2069B10 & 0,04 & $-2,40$ & 2,01 & $-0,10$ \\
\hline omega- 6 fatty acid desaturase & SCRFST1044D02 & $-0,24$ & 2,55 & 2,31 & $-2,60$ \\
\hline putative phosphoserine aminotransferase & SCUTST3092C08 & 1,84 & 1,98 & 2,59 & $-3,42$ \\
\hline
\end{tabular}


Tabela 12. Genes induzidos na variedade tolerante

\begin{tabular}{|c|c|c|c|c|c|}
\hline cinnamoyl-CoA reductase & SCSGST3118E05 & 3,47 & 0,26 & 0,21 & $-0,07$ \\
\hline \multicolumn{6}{|l|}{ Metabolismo de Proteína } \\
\hline putative 60 S ribosomal protein L22 & SCBGRT3075E02 & 3,30 & 0,31 & 1,72 & $-3,10$ \\
\hline $60 S$ ribosomal protein $\mathrm{L} 17$ & SCQGST3126E12 & 0,03 & 1,59 & 1,43 & 3,28 \\
\hline leucyl aminopeptidase - parsley & SCSGST1072B08 & $-0,89$ & 0,01 & $-0,40$ & 3,13 \\
\hline chaperonin; similar to GroEL protein & SCEZRT2020A03 & 3,12 & $-2,26$ & $-0,89$ & 0,00 \\
\hline heat shock protein hsp70 & SCBGLR1118B05 & 1,36 & 0,77 & $-1,20$ & 3,10 \\
\hline similar to translation initiation factor IF2 & SCVPLR2012B03 & 3,00 & $-2,36$ & 0,00 & 0,32 \\
\hline elongation factor Ts & SCJLLR1105G12 & 2,83 & $-2,79$ & 1,59 & 0,14 \\
\hline probable carboxyl-terminal proteinase & SCJFST1047C06 & 2,98 & $-2,83$ & $-1,02$ & 3,36 \\
\hline \multicolumn{6}{|l|}{ Metabolismo de RNA } \\
\hline putative U2 snRNP auxiliary factor & SCJLLR1108C11 & $-0,22$ & 0,26 & 3,04 & 3,15 \\
\hline ND & SCCCLV1001H05 & $-2,96$ & 0,77 & 0,29 & 3,13 \\
\hline MYB-related proteim ZM1 & SCSBST3093C10 & 2,46 & 2,16 & 2,52 & 3,06 \\
\hline RNA helicase & SCSGST1068F12 & $-0,88$ & 2,55 & 1,76 & $-3,40$ \\
\hline \multicolumn{6}{|l|}{ Não Determinados (ND) } \\
\hline ND & SCRFAD1021H07 & 0,81 & 0,13 & $-2,94$ & 3,71 \\
\hline ND & SCCCST3006H09 & $-0,93$ & 0,03 & $-0,07$ & 3,26 \\
\hline ND & SCCCLR1C03C06 & $-3,10$ & 2,04 & 2,79 & 3,26 \\
\hline ND & SCSFLR2031A01 & 2,32 & 1,00 & 0,43 & 3,25 \\
\hline ND & SCCCST1C02D04 & $-0,96$ & 3,05 & $-0,56$ & 2,95 \\
\hline ND & SCRLLR1111C05 & 0,24 & 0,83 & 2,55 & 3,04 \\
\hline ND & SCACLR2022D07 & 2,13 & 3,04 & 2,29 & 2,48 \\
\hline ND & SCMCLR1122F09 & $-1,16$ & $-0,70$ & 2,10 & 3,00 \\
\hline \multicolumn{6}{|l|}{ Proteína de Armazenamento } \\
\hline vegetative storage protein & SCJLFL1051A09 & 3,71 & $-0,76$ & 0,59 & $-2,42$ \\
\hline \multicolumn{6}{|l|}{ Transdução de Sinal } \\
\hline serine/threonine kinases & SCCCLR2C01G05 & $-0,96$ & 0,74 & 2,57 & 3,11 \\
\hline secreted glycoprotein 2 & SCMCST1057G07 & 0,54 & 0,52 & 3,06 & $-2,78$ \\
\hline lectin-like protein kinase-like & SCCCST1C06C01 & $-2,51$ & 2,93 & $-0,05$ & $-2,84$ \\
\hline \multicolumn{6}{|l|}{ Transporte } \\
\hline probable plasma membrane intrinsic protein & SCVPST1061H08 & $-0,20$ & $-2,46$ & $-2,71$ & 3,28 \\
\hline putative calmodulin & SCAGLR2018B04 & $-0,72$ & 2,80 & 2,51 & 3,08 \\
\hline sugar transporter protein & SCSGST3120A03 & 0,03 & 2,63 & 0,36 & 3,07 \\
\hline probable plasma membrane intrinsic protein & SCVPST1061H08 & $-0,20$ & $-2,46$ & $-2,71$ & 3,28 \\
\hline
\end{tabular}


Nas Tabelas 13 e 14 são apresentados alguns genes inibidos nas duas variedades. Na variedade susceptível (Tabela 13), quatro classes gênicas tiveram uma inibição significativa de seus genes, a saber: de dinâmica celular, de metabolismo de DNA, de metabolismo de lipídios e de elementos móveis. A única inibição significativa na variedade tolerante foi na classe de metabolismo de proteína. Um gene muito importante foi encontrado entre os genes inibidos na variedade tolerante, auxin-induced protein, agrupado na classe de crescimento e desenvolvimento da planta (Tabela 14). É sabido que a auxina regula o desenvolvimento da planta afetando a expressão de vários genes (Napier \& Venis, 1995; Sitbon \& Perrot-Rechenmann, 1997). Estes reguladores vegetais são importantes, pois ativam fatores de transcrição que participam de uma cascata de expressões gênicas (Abel et al., 1994; Kim et al., 1997). No entanto, a auxina exerce um efeito antagônico aos efeitos do ácido jasmônico (Creelman \& Mullet, 1997; Rojo et al., 1998; Sasaki et al., 2001). Kernan \& Thornburg (1989) reportaram a auxina como inibidor do gene pin2 em plantas de tabaco. DeWald et al. (1994) mostraram que a auxina inibe a produção de metil-jasmonato e de vegetative storage protein (VSP) e que também inibe o gene da lipoxigenase em plantas de soja. 
Tabela 13. Genes inibidos na variedade susceptível

\begin{tabular}{|c|c|c|c|c|c|}
\hline \multirow[t]{2}{*}{ Descrição } & \multirow[t]{2}{*}{ Longest } & \multicolumn{4}{|c|}{ Log (Razão) } \\
\hline & & $0.5 \mathrm{~h}$ & $6 \mathrm{~h}$ & $12 \mathrm{~h}$ & $24 \mathrm{~h}$ \\
\hline \multicolumn{6}{|l|}{ Bioenergética } \\
\hline peptidase alpha-II chain precursor & SCSGST3121A10 & $-0,34$ & $-2,21$ & 0,00 & 0,04 \\
\hline nodulin & SCJLLR1106C06 & 0,05 & $-1,01$ & $-0,37$ & $-3,17$ \\
\hline putative anthocyanin 5-O-glucosyltransferase & SCSGLV1004A12 & $-1,50$ & 0,00 & 2,73 & $-2,36$ \\
\hline glucanase; glucan endo-1,3-beta-glucosidase & SCSFAD1125E10 & 0,20 & $-0,44$ & $-0,39$ & $-3,12$ \\
\hline THA4 & SCBGLR1119B11 & 0,70 & $-0,67$ & $-2,40$ & $-1,74$ \\
\hline light-harvesting complex protein & SCRLLR1131G03 & $-0,93$ & $-0,42$ & $-2,76$ & $-2,47$ \\
\hline Crescimento/Desenvolvimento & & & & & $-3,12$ \\
\hline homeodomain transcription factor KNAT6 & SCBGLR1100A10 & 0,45 & $-3,28$ & 2,72 & 3,08 \\
\hline \multicolumn{6}{|l|}{ Dinâmica Celular } \\
\hline myb factor protein & SUCASTE1 & 0,56 & $-3,43$ & $-0,70$ & $-0,79$ \\
\hline nucleoid DNA-binding protein cnd41-like protein & SCJLLR1107E12 & $-0,10$ & 0,46 & $-2,20$ & 0,77 \\
\hline SP8 binding protein homolog & SCQGLB2042B04 & 0,37 & $-3,04$ & 0,47 & 1,98 \\
\hline tubulin beta-7 chain & SCQSST3114C01 & $-0,01$ & $-0,55$ & $-2,62$ & 0,47 \\
\hline myb-related transcription factor & SCBGST3108E12 & 0,24 & 2,90 & 0,34 & $-2,41$ \\
\hline alpha-expansin OsEXP7 & SCJLLR1105G05 & 0,11 & $-0,42$ & $-2,63$ & 0,62 \\
\hline MAP3K epsilon protein kinase & SCQGAM2028G06 & 0,45 & $-0,22$ & 0,13 & $-2,51$ \\
\hline \multicolumn{6}{|l|}{ Elementos Móveis } \\
\hline high mobility group I/Y-2 & SCEQLR1094C08 & 0,48 & 2,71 & 0,34 & $-2,86$ \\
\hline putative gag-pol polyprotein & SCSBST3098H04 & $-0,07$ & $-0,93$ & $-0,49$ & $-2,41$ \\
\hline putative reverse transcriptase & SCSFST3082E10 & 0,38 & $-2,65$ & 0,64 & $-2,69$ \\
\hline \multicolumn{6}{|l|}{ Estresse } \\
\hline putative wound-induced protein & SCCCLR2C02A01 & $-0,13$ & 2,70 & $-3,09$ & $-0,48$ \\
\hline wound-induced protein & SCMCLR1122D11 & $-2,58$ & $-2,96$ & $-1,57$ & $-2,66$ \\
\hline peroxidase & SCSGSB1005A06 & 0,10 & $-0,28$ & $-2,71$ & $-1,42$ \\
\hline putative glutathione S-transferase OsGSTU4 & SCCCCL4015B02 & 1,48 & 0,42 & $-2,49$ & $-0,13$ \\
\hline peroxidase 4 precursor & SCBGST3106C01 & 3,17 & $-2,43$ & 1,84 & 2,83 \\
\hline Metallothionein-like protein type 2 & SCBGST3103A07 & 0,34 & 2,94 & $-2,56$ & 1,58 \\
\hline Superoxide dismutase & SCQGLR1088H10 & $-0,03$ & $-3,45$ & 2,45 & $-2,66$ \\
\hline pathogenesis related protein-1 & SCEZLB1010C02 & 0,32 & $-0,60$ & $-0,42$ & $-2,70$ \\
\hline serine/threonine-specific receptor protein kinase & SCRFST1042D08 & $-2,52$ & 0,25 & $-0,99$ & $-2,70$ \\
\hline whitefly-induced gp91-phox & SCEZHR1086B06 & 0,60 & $-1,34$ & $-0,35$ & $-2,60$ \\
\hline cysteine proteinase inhibitor & SCCCFL3003E06 & 0,27 & 0,12 & $-0,01$ & $-3,12$ \\
\hline Barwin, Basic Barley Seed Protein & SCBGRT1049B06 & 0,34 & $-2,73$ & 2,82 & 0,32 \\
\hline 1,3-beta-glucanase PRm 6b & SCQGRT1042E04 & 0,30 & 0,14 & $-2,90$ & $-3,06$ \\
\hline \multicolumn{6}{|l|}{ Metabolismo Secundário } \\
\hline cinnamoyl-CoA reductase & SCQGLB1027G09 & 0,21 & $-0,91$ & $-2,44$ & $-0,20$ \\
\hline dihydrokaempferol 4-reductase A & SCJLRT1020E06 & 0,90 & 0,45 & $-2,55$ & $-0,18$ \\
\hline \multicolumn{6}{|l|}{ Metabolismo de Aminoácidos } \\
\hline Phosphoserine aminotransferase & SCAGLR2033C06 & 0,31 & $-2,64$ & $-0,08$ & $-2,82$ \\
\hline dihydrolipoamide dehydrogenase precursor & SCSFST3076C11 & 0,61 & $-0,24$ & $-2,61$ & $-1,55$ \\
\hline acyl-CoA dehydrogenases & SCMCST1058D11 & 1,83 & $-0,78$ & $-0,41$ & $-3,70$ \\
\hline
\end{tabular}


Tabela 13. Genes inibidos na variedade susceptível

\begin{tabular}{|c|c|c|c|c|c|}
\hline \multicolumn{6}{|l|}{ Metabolismo de DNA } \\
\hline Regulator of chromosome condensation-like protein & SCCCLR2001C02 & 0,07 & 2,21 & 0,00 & $-2,81$ \\
\hline SSRP1 protein & SCBGST3108C09 & 0,61 & $-2,39$ & 0,64 & 0,87 \\
\hline Peptide methionine sulfoxide reductase & SCAGLR2018F12 & $-0,77$ & $-3,22$ & $-0,19$ & 2,71 \\
\hline histone $\mathrm{H} 2 \mathrm{~A}$ & SCJLLR1101A02 & 2,72 & $-3,40$ & $-1,09$ & 0,59 \\
\hline \multicolumn{6}{|l|}{ Metabolismo de Lipídeos } \\
\hline lipase & SCUTLR2030E01 & $-0,14$ & $-0,12$ & $-0,61$ & $-2,27$ \\
\hline lysophospholipase-like protein & SCRFLR2038C11 & $-2,13$ & 0,71 & 0,02 & $-2,56$ \\
\hline HMG-CoA synthase & SCSBST3098E12 & 2,65 & $-2,22$ & 3,07 & 0,41 \\
\hline lipoxygenase & SCBGRT1053H02 & 0,62 & $-0,23$ & 0,00 & $-3,06$ \\
\hline phosphoinositide-specific phospholipase C & SCSBST3099D05 & 0,14 & $-2,34$ & 1,05 & 0,29 \\
\hline acyl-CoA-binding protein & SCCCST3006H06 & $-0,31$ & 0,35 & $-3,17$ & 0,60 \\
\hline allene oxide synthase & SCJFRZ3C05G02 & 0,29 & $-0,10$ & $-2,45$ & 0,73 \\
\hline GDSL-motif lipase/hydrolase-like protein & SCSFLR2009E05 & $-0,81$ & 0,90 & $-3,32$ & $-0,36$ \\
\hline lipase-like protein & SCCCLR2004B05 & 0,90 & $-2,88$ & 2,61 & 2,83 \\
\hline \multicolumn{6}{|l|}{ Metabolismo de Nitrogênio, Enxofre e Fosfato } \\
\hline MtN3 & SCBGST3108B10 & $-0,18$ & 2,73 & $-2,73$ & 0,03 \\
\hline \multicolumn{6}{|l|}{ Metabolismo de Nucleotídeos } \\
\hline Glycyl tRNA synthetase & SCMCST1056F08 & 0,12 & $-0,43$ & $-2,26$ & 2,69 \\
\hline ADP-ribosylation factor-like protein & SCMCLR1123E07 & $-0,33$ & $-3,33$ & 2,47 & 2,11 \\
\hline \multicolumn{6}{|l|}{ Metabolismo de Proteína } \\
\hline cyclophylin-like protein & SCSGAD1009F02 & 0,84 & $-3,37$ & $-2,46$ & 0,36 \\
\hline translation initiation factor IF2 & SCVPLR2012B03 & 0,59 & 1,38 & $-2,50$ & $-0,21$ \\
\hline ubiquitin protein & SCSFST1066F08 & 2,00 & $-2,65$ & 0,00 & $-2,87$ \\
\hline probable carboxyl-terminal proteinase & SCJFST1047C06 & 0,96 & $-0,20$ & $-2,60$ & 0,14 \\
\hline \multicolumn{6}{|l|}{ Metabolismo de RNA } \\
\hline Small nuclear ribonucleoprotein G & SCBGLR1116D01 & 0,46 & $-2,75$ & $-0,37$ & $-0,58$ \\
\hline RNA helicase & SCSGST1068F12 & $-0,65$ & $-0,53$ & $-2,59$ & $-2,78$ \\
\hline zinc finger protein & SCCCST3003D12 & 0,35 & 0,36 & $-2,17$ & $-0,75$ \\
\hline \multicolumn{6}{|l|}{ Não Determinados (ND) } \\
\hline ND & SCAGLR2033C02 & $-2,41$ & 1,71 & 2,51 & $-2,58$ \\
\hline ND & SCCCLV1001E06 & $-0,41$ & $-2,42$ & $-0,77$ & 0,06 \\
\hline ND & SCSFST1064H01 & 2,71 & $-3,30$ & $-2,89$ & $-1,30$ \\
\hline ND & SCSFST1066C11 & $-0,56$ & 3,35 & $-0,61$ & $-3,25$ \\
\hline \multicolumn{6}{|l|}{ Transdução de Sinal } \\
\hline protein kinase-like protein & SCQSST3115B02 & 0,49 & $-2,91$ & $-0,45$ & $-0,13$ \\
\hline receptor-protein kinase-like protein & SCSFLR2016D06 & 0,08 & $-0,03$ & $-2,84$ & $-0,32$ \\
\hline probable serine/threonine-specific protein kinase & SCSGST1072H02 & 0,89 & 0,42 & 0,25 & $-3,12$ \\
\hline calcium-dependent protein kinase 7 & SCSBAD1126C01 & 0,39 & $-2,88$ & 0,68 & $-0,81$ \\
\hline calmodulin & SCJFLR2035A01 & $-2,28$ & 0,00 & $-0,01$ & 0,45 \\
\hline \multicolumn{6}{|l|}{ Transporte } \\
\hline nonspecific lipid-transfer protein 1 precursor & SCSGST3119G09 & $-0,04$ & $-0,84$ & $-0,45$ & $-2,80$ \\
\hline transport protein subunit-like & SCBGLR1114A02 & $-2,67$ & 2,62 & 2,47 & 0,22 \\
\hline ferritin 1 precursor & SCEPAM1053E12 & 0,01 & $-0,07$ & 0,49 & $-3,21$ \\
\hline
\end{tabular}


Tabela 14. Genes inibidos na variedade tolerante

\begin{tabular}{|c|c|c|c|c|c|}
\hline \multirow[t]{2}{*}{ Descrição } & \multirow[t]{2}{*}{ Longest } & \multicolumn{4}{|c|}{ Log (Razão) } \\
\hline & & $0.5 \mathrm{~h}$ & $6 \mathrm{~h}$ & $12 \mathrm{~h}$ & $24 \mathrm{~h}$ \\
\hline \multicolumn{6}{|l|}{ Bioenergética } \\
\hline O-succinylhomoserine lyase & SCCCST3083E07 & $-1,33$ & 1,42 & $-2,85$ & $-0,49$ \\
\hline high pl alpha-glucosidase & SCBGLR1120C02 & $-0,72$ & $-2,44$ & $-2,89$ & $-0,47$ \\
\hline seed starch branching enzyme & SCQSST3115G05 & $-0,48$ & 0,25 & $-0,16$ & $-2,04$ \\
\hline \multicolumn{6}{|l|}{ Crescimento/Desenvolvimento } \\
\hline auxin-induced protein & SCSGST3119D05 & $-0,95$ & 1,64 & $-2,93$ & 0,00 \\
\hline pectin acetylesterase & SCSGST1071E07 & $-2,97$ & $-1,43$ & 1,19 & 0,54 \\
\hline probable ethylene-response protein & SCAGAM2123E05 & $-0,12$ & $-2,60$ & $-0,86$ & 0,83 \\
\hline ethylene receptor CS-ETR2 & SCSGLV1006C01 & $-3,09$ & 0,20 & $-0,74$ & 0,01 \\
\hline \multicolumn{6}{|l|}{ Dinâmica Celular } \\
\hline probable transcription factor & SCCCFL5065C01 & 3,19 & $-0,24$ & 1,98 & $-2,86$ \\
\hline proline-rich protein & SCSFST3073F10 & $-1,22$ & $-0,52$ & $-2,18$ & $-0,07$ \\
\hline pirin & SCCCLR2C02B09 & $-2,92$ & 1,38 & 0,72 & 1,48 \\
\hline chitinase & SCCCRT3002H12 & 0,84 & 0,56 & $-2,01$ & 2,33 \\
\hline ethylene-responsive transcriptional coactivator & SCCCLR2C02C02 & $-0,63$ & 0,91 & $-2,21$ & 0,00 \\
\hline \multicolumn{6}{|l|}{ Elementos Móveis } \\
\hline putative reverse transcriptase & SCQSST3115C01 & $-0,32$ & $-2,26$ & $-0,46$ & $-0,83$ \\
\hline retroelement pol polyprotein-like & SCVPST1063C05 & $-0,14$ & 1,02 & 2,15 & $-2,83$ \\
\hline similar to putative reverse transcriptase & SCSFST3082E10 & $-0,62$ & 1,02 & $-2,61$ & $-0,67$ \\
\hline \multicolumn{6}{|l|}{ Estresse } \\
\hline putative wound-induced protein & SCCCLR2C02A01 & 0,70 & $-2,08$ & 2,38 & 0,02 \\
\hline wound-induced protein & SCMCLR1122D11 & $-0,17$ & $-2,06$ & $-0,46$ & 2,96 \\
\hline peroxidase & SCSGSB1005A06 & 1,11 & $-2,03$ & $-0,02$ & 0,43 \\
\hline putative glutathione S-transferase OsGSTU4 & SCCCCL4015B02 & $-0,89$ & $-2,21$ & 0,00 & $-0,80$ \\
\hline laccase & SCUTST3084C11 & $-3,21$ & 2,99 & 0,30 & 2,78 \\
\hline MLA6 protein & SCACLR1126F06 & 1,85 & 0,00 & 0,09 & $-3,13$ \\
\hline osmotin-like protein precursor & SCJFFL3C08E06 & 0,45 & 0,15 & $-2,32$ & $-2,33$ \\
\hline germin-like protein 5 & SCCCLR2C02D04 & $-2,05$ & $-1,47$ & $-3,25$ & 2,66 \\
\hline putative peroxidase $\mathrm{P} 7 \mathrm{X}$ & SCCCAD1001C08 & 0,28 & $-2,67$ & 0,40 & $-0,18$ \\
\hline \multicolumn{6}{|l|}{ Metabolismo Secundário } \\
\hline choline monooxygenase precursor & SCJFHR1030B02 & 0,28 & 0,39 & 2,71 & $-3,04$ \\
\hline putative glucosyltransferase & SCCCST1C06B03 & $-0,78$ & 0,33 & $-2,68$ & 2,80 \\
\hline probable ferrochelatase & SCUTST3090H08 & 2,46 & $-2,00$ & $-0,08$ & $-0,02$ \\
\hline \multicolumn{6}{|l|}{ Metabolismo de Aminoácidos } \\
\hline probable tyrosine-tRNA ligase & SCCCLR1C01A11 & $-0,40$ & $-3,16$ & 0,85 & $-3,27$ \\
\hline dihydroxy-acid dehydratase & SCACLR1132B04 & $-0,16$ & 0,47 & 2,64 & $-2,85$ \\
\hline cytosolic aldehyde dehydrogenase & SCCCLR1C06D07 & $-2,40$ & 0,37 & $-2,79$ & 0,13 \\
\hline GMP synthase & SCVPST1059H11 & 1,38 & $-2,04$ & $-0,03$ & $-1,96$ \\
\hline \multicolumn{6}{|l|}{ Metabolismo de Lipídeos } \\
\hline carnitine racemase like protein & SCAGLR2033B01 & 0,14 & 1,26 & $-2,72$ & 0,31 \\
\hline allene oxide synthase & SCVPAM2069B10 & 0,04 & $-2,40$ & 2,01 & $-0,10$ \\
\hline lipase-like protein & SCCCLR2004B05 & $-0,16$ & $-2,04$ & $-2,06$ & $-0,61$ \\
\hline
\end{tabular}


Tabela 14. Genes inibidos na variedade tolerante

\begin{tabular}{|c|c|c|c|c|c|}
\hline DsPTP1 protein & SCUTST3087E08 & $-0,13$ & 1,01 & $-2,46$ & 0,06 \\
\hline \multicolumn{6}{|l|}{ Metabolismo de Proteína } \\
\hline cyclophylin-like protein & SCSGAD1009F02 & 2,82 & 0,37 & $-0,45$ & $-2,37$ \\
\hline DnaJ protein, putative & SCACLR2022G09 & $-0,72$ & 0,00 & 2,43 & $-2,90$ \\
\hline probable heat shock protein EMB1 & SCCCLR1C11A11 & $-0,22$ & 0,37 & 2,72 & $-3,15$ \\
\hline UDP-glucuronyltransferase-I & SCJFLR2035H01 & $-3,27$ & $-1,60$ & $-2,29$ & $-0,13$ \\
\hline polyubiquitin 5 & SCCCST3001G10 & $-0,01$ & $-3,08$ & $-0,24$ & $-0,02$ \\
\hline $40 S$ ribosomal protein $\mathrm{S} 12$ & SCEQLR1094F02 & $-0,28$ & 0,59 & $-2,94$ & $-0,32$ \\
\hline elongation factor Ts & SCJLLR1105G12 & 2,83 & $-2,79$ & 1,59 & 0,14 \\
\hline similar to translation initiation factor IF2 & SCVPLR2012B03 & 3,00 & $-2,36$ & 0,00 & 0,32 \\
\hline chaperonin; similar to GroEL protein & SCEZRT2020A03 & 3,12 & $-2,26$ & $-0,89$ & 0,00 \\
\hline splicing factor ATP-dependent RNA helicase & SCVPST1060G09 & $-0,44$ & 1,33 & $-2,68$ & 0,67 \\
\hline vesicle transport v-SNARE protein & SCUTLR2008D11 & $-0,59$ & 0,00 & 0,48 & $-2,99$ \\
\hline probable carboxyl-terminal proteinase & SCJFST1047C06 & 2,98 & $-2,83$ & $-1,02$ & 3,36 \\
\hline heat shock protein 17.2 & SCCCLR1C06F08 & $-0,44$ & $-2,12$ & 0,33 & $-0,53$ \\
\hline \multicolumn{6}{|l|}{ Metabolismo de RNA } \\
\hline putative transcription factor & SCSGST1069D04 & 1,94 & $-1,90$ & $-1,96$ & $-3,28$ \\
\hline RNA helicase & SCSGST1068F12 & $-0,88$ & 2,55 & 1,76 & $-3,40$ \\
\hline \multicolumn{6}{|l|}{ Não Determinados (ND) } \\
\hline ND & SCSGST1068G03 & $-0,04$ & $-2,03$ & $-2,70$ & $-0,13$ \\
\hline ND & SCQGST3122E02 & $-0,60$ & 0,00 & $-2,99$ & 0,00 \\
\hline ND & SCJFLR2035E02 & $-2,50$ & 1,13 & $-0,07$ & 3,23 \\
\hline ND & SCJLLR2006A02 & $-0,94$ & 1,27 & $-0,59$ & $-2,71$ \\
\hline ND & SCCCLR2003H06 & $-0,52$ & $-2,12$ & $-0,03$ & 0,84 \\
\hline ND & SCQSST3114B03 & $-0,78$ & $-2,48$ & $-0,02$ & $-2,86$ \\
\hline ND & SCSFST3073A11 & $-0,36$ & $-0,03$ & $-2,29$ & 1,91 \\
\hline ND & SCSGLV1009G06 & $-0,17$ & $-2,29$ & $-0,40$ & 2,76 \\
\hline \multicolumn{6}{|l|}{ Transdução de Sinal } \\
\hline AMP-activated protein kinase beta & SCCCLR1C01C11 & $-3,06$ & 1,02 & $-0,80$ & 0,25 \\
\hline protein kinase $(\mathrm{PK})$ & SCRFLR2021H11 & $-0,97$ & $-2,69$ & 0,11 & 2,69 \\
\hline ring-box 1 & SCBGLR1115D07 & $-0,41$ & 1,86 & 2,30 & $-2,77$ \\
\hline secreted glycoprotein 2 & SCMCST1057G07 & 0,54 & 0,52 & 3,06 & $-2,78$ \\
\hline lectin-like protein kinase-like & SCCCST1C06C01 & $-2,51$ & 2,93 & $-0,05$ & $-2,84$ \\
\hline Sgt1 & SCQSFL1129A07 & 0,05 & 0,07 & $-2,46$ & 2,87 \\
\hline gigantea homologue & SCJFAD1014B07 & 0,06 & $-2,55$ & $-1,00$ & 0,64 \\
\hline \multicolumn{6}{|l|}{ Transporte } \\
\hline mitochondrial energy transfer protein & SCBGST3105E03 & $-2,93$ & 0,47 & $-0,10$ & 0,67 \\
\hline putative peptide transporter & SCCCST1C02A04 & $-0,64$ & $-0,65$ & $-2,47$ & 0,04 \\
\hline sodium proton exchanger $\mathrm{Nhx} 1$ & SCJFLR2036G10 & $-0,03$ & $-0,40$ & $-0,18$ & $-3,40$ \\
\hline
\end{tabular}




\subsection{Alguns Genes de Interesse Induzidos em Resposta à Herbivoria}

\subsubsection{Sinais Sistêmicos}

As plantas têm uma variedade de defesas químicas para se protegerem de seus inimigos naturais. A indução de respostas defensivas aos insetos pragas é ativada provavelmente por sinais liberados durante os primeiros estágios do ataque do herbívoro. Segundo Falco et al. (2001), estes sinais podem ser fragmentos de pectina derivados da parede celular, ácido jasmônico, ácido abscísico, potenciais elétricos, intermediários da via octadecanóide, ou outros sinais polipeptídicos da planta. De acordo com Ryan (2000), através destas substâncias as plantas podem impedir ou ter efeito deterrente sobre seus herbívoros. Outras respostas das plantas podem ser sinais temporários emitidos do local de ferimento, que atraem predadores naturais do inseto herbívoro, tais como vespas e ácaros (Karban \& Baldwin, 1997).

Foram encontradas diversas ESTs de MAP quinases (mitogenactivated protein kinases), quinases dependentes de $\mathrm{Ca}^{2+}$ e fosfolipases induzidas nas duas variedades. Estas proteínas são envolvidas na ativação da via octadecanóide, associadas geralmente com ataques por herbívoros ou trauma físico similar (Falco et al., 2001).

O gene quinase glicogênio sintase 3 (glycogen synthase kinase 3, GSK-3) foi induzido na variedade susceptível no tempo de 0.5 hora (clone SCJFST1047H12). Segundo Jonak et al. (2000), alfalfa (Medicago sativa cv Europa) ferida mecanicamente apresenta indução deste gene GSK-3. De acordo com estes autores, os resultados aqui apresentados sugerem que o gene GSK-3 pode ser induzido quando plantas de cana-de-açúcar são submetidas à herbivoria. Jonak et al. (2000) também detectaram que os transcritos deste gene são rapidamente acumulados após o ferimento. Assim, estes dados indicam que o gene GSK-3 pode estar envolvido no mecanismo de 
defesa nas plantas. Várias outras proteínas quinase também foram induzidas em cana-de-açúcar em resposta à Diatraea saccharalis.

A calmodulina foi induzida nos tratamentos T12 e T24 (clone SCJFLR2035H04). Segundo Bergey \& Ryan (1999), plantas de tomate transgênicas, superexpressando o gene da pró-sistemina, apresentaram elevação dos níveis do mRNA e da proteína da calmodulina quando comparadas ao tipo-selvagem. Os níveis do mRNA e da proteína da calmodulina também foram altos nas folhas das plantas selvagens submetidas ao ferimento mecânico, ao tratamento com sistemina, metil-jasmonato ou ácido linolênico. Entretanto, estes autores encontraram uma indução de calmodulina 0.5 hora após o ferimento ou a aplicação dos tratamentos, observando o pico de indução no tempo de 1 hora após a montagem. O mesmo não foi observado neste trabalho, possivelmente porque as lagartas se alimentavam de forma contínua, e não em um tempo definido.

Representando as proteínas com atividade fosfolipídica, o gene da vegetative storage protein (VSP) foi induzido somente na variedade tolerante no tempo de 24 horas (clone SCRURZ3082B02). O clone SCQSST1040G01 codificador da proteína patatin, também conhecida por sua atividade de fosfolipase, foi identificado nos tempos de 6, 12 e 24 horas na variedade tolerante. Este gene também foi induzido na variedade susceptível, nos tempos de 6 e 24 horas.

A existência de vias de sinalização parece ser uma estratégia da planta para amplificar mecanismos de defesa em resposta ao ataque de insetos herbívoros. Dentro da classe de genes envolvidos na via octadecanóide, foram encontrados os genes da lipoxigenase (LOX) e do alene oxido sintase (AOS). Estas enzimas residem no cloroplasto onde eles participam na conversão de ácido linolênico a moléculas de ácido jasmônico, entre outras substâncias (Falco et al., 2001). 
O gene da lipoxigenase (clone SCBGRT1053H02) foi induzido nas plantas da variedade susceptível. Este gene foi responsivo no tempo de 0.5 hora após a montagem do experimento, indicando uma resposta rápida de defesa da planta. $O$ aumento dos níveis de lipoxigenase também foi detectado em plantas submetidas à herbivoria (Hildebrand, 1989), infecção por microorganismos (Keppler \& Novacky, 1987; Koch et al., 1992; Fournier et al., 1993; Melan et al., 1993), estresse hídrico (Bell \& Mullet, 1991), e danos mecânicos (Geerts et al., 1994; Saravitz e Siedow, 1995). Em soja (Glycine max) dois cDNAs contendo o gene da lipoxygenase (LOX) foram isolados. Estes clones representam os genes designados por LOX7 e LOX8. Em trabalho realizado por Saravitz \& Siedow (1996) foi observado que a expressão destes genes era aumentada quando as folhas eram submetidas ao ferimento mecânico. Estes autores observaram que os níveis dos transcritos de ambos os genes eram detectados nas folhas feridas 8 horas após o ferimento. Somente a expressão de LOX7 indicou uma resposta sistêmica de defesa ao ferimento. Adicionalmente, eles observaram que a expressão elevada de LOX7 nas folhas feridas era transiente. Vinte e quatro horas após o ferimento, os transcritos de LOX7 já não eram mais detectáveis nas folhas. Ao contrário, os níveis dos transcritos de LOX8 elevavam nas folhas feridas após 8 a 72 horas de ferimento. Outro trabalho indicando a presença da lipoxigenase em ferimentos foi o de Heitz et al. (1997). Este grupo mostrou a expressão da lipoxigenase em plantas de tomate submetidas ao ferimento mecânico. Segundo estes autores, foram encontradas LOXC e LOXD. Os níveis de LOXD foram elevados após 30 a 50 minutos do ferimento, alcançando um máximo entre 1 e 2 horas. O mRNA de LOXC não foi detectado nas folhas após o ferimento. Reymond et al. (2000) encontraram o gene LOX2 envolvido na síntese ou no metabolismo dos membros da família dos jasmonatos, os quais foram induzidos nos primeiros estágios do mecanismo de defesa em plantas de Arabidopsis submetidas ao ferimento mecânico. Segundo Arimura et al. (2000a), a LOX também foi induzida em plantas de feijão (Phaseolus vulgaris) em resposta ao ácaro 
Tetranicus urticae. Sasaki et al. (2001) relataram a indução da LOX em Arabidopsis thaliana como um gene potencialmente regulado por ácido jasmônico.

Uma outra proteína importante da via octadecanóide é a alene oxido sintase (AOS), que catalisa uma das etapas da biossíntese do ácido jasmônico a partir dos ácidos graxos livres. Esta proteína foi induzida nos tratamentos S24 (clone SCJFRZ3C05G02) e T12 (clone SCVPAM2069B10).

O clone SCSFHR1045B07 foi induzido na variedade susceptível nos tempos de 0.5 e 12 horas. O mesmo foi induzido na variedade tolerante, porém somente no tempo de 24 horas. Este clone codifica a proteína 1aminocyclopropane-1-carboxylate (ACC) oxidase. $\mathrm{Na}$ variedade tolerante outro clone, SCEZLR1009E06, também codificador desta proteína foi encontrado induzido nos tempos de 0.5 e 6 horas. Segundo Abeles et al. (1992), quando a ACC é oxidada pela enzima 1-aminocyclopropane-1-carboxylate oxidase (ACO), o etileno é obtido como produto final. De acordo com Kato et al. (2000), o fitorregulador etileno é produzido em resposta a vários tipos de estresses, tais como ferimentos, doenças, exposição à baixa temperatura ou à produtos químicos e estresse hídrico.

A fenilalanina amônia liase (phenylalanina ammonia lyase, PAL) foi induzida nas duas variedades. Foram encontradas nos tempos de S0.5 (clone SCQGSB1083E01), T0.5 e T24 (clone SCEZST3149F10). A PAL é uma enzima encontrada na fase inicial da síntese de compostos fenólicos, os quais são responsáveis pelas atividades antioxidantes das células (Larson, 1988). Segundo Martínez-Téllez \& Lafuente (1997) a atividade da PAL foi aumentada em plantas de citrus submetidas ao estresse térmico, como também estudado por Lafuente et al. (2001). Esta enzima já foi igualmente relatada sendo induzida em plantas de Arabidopsis submetidas ao ferimento mecânico (Reymond et al., 2000), em mutantes de Rhodotorula glutinis A-97 submetidos à radiação gama (El-Batal et al., 2000), e em raízes de plantas de tomate submetidas à diferentes concentrações de nitrato (Wang et al., 2001). Segundo 
Arimura et al. (2000a), a PAL também foi induzida em plantas de feijão (Phaseolus vulgaris) submetidas ao ácaro Tetranicus urticae.

Diversas moléculas foram relatadas sendo elicitoras de proteínas da defesa. Segundo Somerville et al. (2000), thaumatin-like protein tem como função sinalizar as células, desencadeando uma barreira protetora no local ferido que conduz o desenvolvimento de uma cascata de eventos que as mobiliza contra um possível ataque. Esta proteína foi encontrada induzida somente na variedade susceptível no tempo de 6 horas, representada pelo clone SCBFSD2035E07. Clones codificadores de substâncias antioxidantes também foram encontrados como sendo responsivos em cana-de-açúcar ao ferimento causado pela lagarta, tais como peroxidases, catalases e superóxido dismutase. No processo de desintoxicação celular, a ação combinada destes sistemas enzimáticos é importante para evitar danos oxidativos celulares, pois estas enzimas são capazes de remover ou neutralizar espécies de oxigênio reativas (ROS) no interior das células (Scandalios, 1993).

\subsubsection{Proteínas de Defesa}

De acordo com Ryan \& Pearce (2001), uma acumulação rápida de inibidores pode ser observada não somente em folhas feridas mas também em folhas distantes não submetidas ao ferimento, indicando que um sinal (ou os sinais) liberado do local da ferida pode percorrer toda a planta. Estudando mecanismos de defesa em cana-de-açúcar contra a herbivoria, Falco et al. (2001) relataram que estes inibidores podem incluir inibidores de protease (PIs), inibidores de $\alpha$-amilase, lecitinas, quitinases e polifenol oxidases (PPO). A seguir serão discutidos alguns dos genes induzidos neste trabalho.

Endopeptidases ou proteases são enzimas que clivam ligações internas dos peptídeos em sítios específicos, de acordo com o aminoácido que o compõe. Estes sítios podem ser do tipo serina, cisteína, proteases do ácido aspártico e metalloproteases. As proteases do tipo serina são as principais 
enzimas digestivas encontradas quando o $\mathrm{pH}$ do lúmen do intestino médio do inseto é neutro ou alcalino, por exemplo em lepidópteros. As proteases do tipo cisteína e do ácido aspartico são encontradas em intestinos ácidos, como ocorrem nos coleópteros. Outras enzimas digestivas também estão presentes nos insetos, tais como amilases e lipases. Hemípteros não possuem proteases digestivas, assim sua fonte de nitrogênio é através da sucção de aminoácidos livres presentes no floema (Terra e Ferreira, 1994). No entanto, durante a evolução, plantas e insetos se adaptaram às novas condições ecológicas, fisiológicas e bioquímicas, a fim de diminuir os efeitos negativos desta interação (Mello e Silva-Filho, 2002). Como resultado, hoje encontramos plantas com mecanismos contra as proteases dos insetos, tais como o aumento da atividade de inibidores nos tecidos (Rakwal et al., 2001), a síntese de uma gama enorme de inibidores que possuem atividade contra várias enzimas (Christeller et al., 1998), a produção de inibidores bifuncionais que atuam contra amilases e proteases (Roy \& Gupta, 2000), o aumento da complexidade dos inibidores com propriedades bioquímicas diferentes por meio da produção de isoinibidores (Tiffin \& Gaut, 2001), a expressão de inibidores altamente específicos para as enzimas dos insetos (Falco et al., 2001) e a síntese de inibidores resistentes a proteólise e ativos sob várias condições de $\mathrm{pH}$ do trato digestivo de insetos (Christeller et al., 1998).

Representando a classe de proteínas anti-nutricionais, inibidores de protease do tipo cisteína (cistatinas) foram encontrados induzidos na variedade tolerante de cana-de-açúcar. Estes genes, representados pelos clones SCSGST3121C03 e SCCCFL3003E06, foram induzidos em três tempos dos experimentos. O primeiro clone foi induzido nos tempos de 6, 12 e 24 horas, já o segundo em 0.5, 12 e 24 horas. Nas plantas, as cistatinas são envolvidas na degradação das proteínas, exercendo um papel importante na resistência aos insetos. Estas cistatinas são distribuídas extensamente nas plantas e foram isoladas de arroz (Abe et al., 1987a,b), milho (Abe et al., 1992), e soja (Hines et al., 1991). 
Inibidores de proteases do tipo quimotripsina foram induzidos na variedade susceptível nos tempos de $0.5,6$ e 24 horas, representado pelo clone SCSBRT3040B04. Inibidores de proteases do tipo quimotripsina induzidos por ferimento ou herbivoria pertencem à família dos inibidores Bowman-Birk (IBB) e foram isolados e caracterizados em milho (Rohrmeier \& Lehle, 1993), alfafa (McGurl et al., 1995) e arroz (Rakwal et al., 2001). Recentemente foi reportado que a uma classe de inibidores de serino-proteases do tipo Bowman-Birk, composta por 7 isoformas, foi expressa em praticamente todos os tecidos da cana-de-açúcar (Mello et al., 2003). O significado fisiológico dos IBB está associado com suas três principais funções nas plantas: regulação das proteases endógenas, reserva de aminoácidos sulfurados e defesa contra o ataque de patógenos e insetos. No último caso, os IBB parecem atuar inibindo a atividade proteolítica das enzimas digestivas dos insetos, interferindo em seu desenvolvimento e reprodução (Tanaka et al., 1996; Pompermayer et al., 2001; Tiffin \& Gaut, 2001; Pompermayer et al., 2003). Somente alguns estudos mostraram o uso potencial dos inibidores de protease do tipo serina (IBB) no controle de pragas (Gatehouse \& Boulter, 1983; Leplé et al., 1995; Falco \& Silva-Filho, 2003). Embora as atividades dos inibidores de protease do tipo serina sejam bem caracterizadas, o papel dos inibidores do tipo Bowman-Birk não foram totalmente elucidados (Pernas et al., 2000).

Outro inibidor que também atua no processo digestivo do inseto é a $\alpha$-amilase, inibindo a digestão de carboidratos. O gene codificador deste inibidor foi induzido na variedade susceptível no tempo de 6 horas (clone SCEPCL6025G08). A atividade do inibidor da a-amilase é específica para amilases dos animais (incluindo os insetos) e dos microrganismos, sendo rara a sua atividade com carboidratos da planta. Considerável variabilidade é encontrada no sitio ativo destes inibidores. Assim, os inibidores de a-amilase são parte do mecanismo químico protetor das plantas (Ryan, 1990). Os inibidores de a-amilase do trigo são potentes inibidores de diversos insetos, incluindo Tenebrio, Tribolium, Sitophilus e Oryzaephilus. A propriedade 
inseticida dos inibidores de $\alpha$-amilase tem sido explorada em plantas transgênicas. Morton et al. (2000) utilizaram plantas de ervilha (Pisum sativum) transformadas com gene inibidor de a-amilase de feijão (Phaseolus vulgaris) e observaram que a expressão deste gene, em sementes e em plantas de ervilhas sob condições de campo, pode inibir o inseto Bruchus pisorum, praga desta planta. De acordo com estes autores, as plantas transgênicas atrasaram o desenvolvimento larval do inseto, resultando em uma alta taxa de mortalidade nos primeiros estágios larvais.

O gene que codifica proteína inibidora da poligalacturonase foi identificado nos tratamentos T0.5 (clone SCSGLV1007G11S6), T6 (clone SCSGLV1007G11) e S6 (clone SCQGHR1012F03). Poligalacturonases são enzimas produzidas pelos insetos que rompem a pectina da parede celular nas plantas. No entanto, proteínas inibidoras de poligalacturonase (PIPG) são eficazes à prevenção por infecção por fungos e não é sabida a atuação destas proteínas em resposta ao ataque dos insetos (Abu-Goukh \& Labavitch, 1983). A razão para a falta do conhecimento da atividade destas proteínas em insetos é porque poucas pesquisas foram conduzidas na busca destas enzimas em insetos. Trabalhando com Diaprepes abbreviatus, uma praga do citrus na Flórida, Doostdar et al. (2002) identificaram poligalacturonases no inseto e mostrou que estas podem ser inibidas por PIPG isoladas de cascas de uva.

Quitinases e endoquitinases também foram encontradas induzidas em cana-de-açúcar. As quitinase da classe III foram induzidas nos seguintes tratamentos: S0.5 (clone SCJLRT1015B03), S6 (clone SCSBRT3039E08), T0.5 (clone SCMCSD1059D07), T6 (clone SCSBRT3039E08) e T24 (clone SCSBRT3039E08). Quitinases da classe $V$ estavam presentes somente na variedade tolerante, no tempo de 24 horas (clone SCCCFL5057C01). O precursor das endoquitinases A2 foi encontrado somente nas plantas susceptíveis, nos tempos de 0.5 (clone SCSGLV1013A05) e 6 horas (clone SCJLLB2076C12). Broglie \& Broglie (1993) descreveram estas enzimas como barreiras de proteção contra ataque de patógenos. Segundo Grison et al. 
(1996), plantas transgênicas com a expressão constitutiva de quitinases mostraram níveis realçados de resistência à infecção contra os fungos Cylindrosporium concentricum, Phoma lingam e Sclerotinia sclerotiorum. Embora estudado principalmente por suas propriedades anti-fúngicas, as quitinases estão interessando também como um agente de defesa contra os insetos, particularmente insetos da ordem Hemíptera (Gatehouse \& Gatehouse, 1998). Nos insetos, a quitina está presente não somente como constituinte do exoesqueleto, mas também na membrana peritrófica, permitindo supor o efeito das quitinases na digestão do inseto (Jouanin et al., 1998). Plantas transgênicas de batata contendo o gene codificador da quitinase do feijão foram resistentes aos afídios Aulacorthum solani (Gatehouse \& Gatehouse, 1998). A expressão de quitinases de insetos em plantas transgênicas causou danos severos ao besouro Oryzaephilis mercator (Wang et al., 1996). Endoquitinases foram descritas por Arimura et al. (2000a) como induzidas em plantas de feijão (Phaseolus vulgaris) em resposta ao ácaro Tetranicus urticae e quitinases foram relatadas como envolvidas no mecanismo de defesa em plantas de Arabidopsis submetidas ao ferimento mecânico (Reymond et al., 2000) e em plantas de arroz submetidas ao fungo Pyricularia grisea (Xiong et al., 2001).

Polifenol oxidase (PPO) foi também um gene induzido somente na variedade tolerante. Representado pelo clone SCEPAM1051D07, este gene foi induzido nos tempos de $0.5,12$ e 24 horas. O papel das PPOs no mecanismo de defesa das plantas em resposta aos insetos foi proposto e documentado por Felton et al. (1989). Durante o ferimento (raspagem ou corte) das plantas pelos insetos que estão se alimentando, misturas de PPO e compostos fenólicos geram substâncias altamente reativas que podem modificar covalentemente os aminoácidos livres dentro do aparelho digestivo dos insetos. Uma vez modificados, estes aminoácidos tornam-se alquilados e não podem ser assimilados eficientemente, reduzindo assim, o valor nutritivo das proteínas ingeridas (Felton et al., 1992). Este efeito anti-nutritivo das PPOs foi observado 
em tomate, onde a indução de PPO ocorreu concomitantemente com outras proteínas sabidas de defesa (Constabel et al., 1995; Bergey et al., 1996).

Entre os genes de interesse induzidos em resposta à herbivoria, não houve diferença quanto aos sinais sistêmicos presentes nas duas variedades. Entretanto, em relação às proteínas de defesa, a variedade tolerante mostrou ser mais responsiva.

Uma outra observação importante desta avaliação em larga escala da resposta de plantas de cana-de-açúcar à Diatraea saccharalis é que na variedade tolerante $\mathrm{o}$ ataque da broca da cana mostrou um significativo aumento na expressão de genes no estádios iniciais da herbivoria, notadamente após 6 hs. Esta observação abre novas perspectivas no entendimento dos mecanismos genéticos que controlam a resistência de plantas às pragas. Caso estes dados sejam confirmados a partir de uma segunda análise do experimento, pode-se supor que um dos aspectos determinantes da resistência de uma planta ao ataque de uma praga seja mediado pela rapidez na ativação ou repressão de genes envolvidos no processo de defesa. Contudo, como comentado anteriormente, é necessário analisar estes dados não de forma absoluta, mas estudos complementares deverão ser realizados para permitir uma interpretação mais sólida do trabalho. Neste sentido, técnicas de análise de expressão gênica fornecerão subsídios importantes para um melhor entendimento sobre o modo das respostas de defesas das plantas de cana-de-açúcar à Diatraea saccharalis e sua relação com os aspectos levantados de mecanismos genéticos de tolerância e resistência. 


\section{CONCLUSÕES}

* A técnica de macroarranjos de colônias bacterianas é uma alternativa robusta e pouco dispendiosa para análise em larga escala da expressão gênica.

* Macroarranjos de colônias bacterianas crescidas por 6 horas mostraram uma melhor uniformidade entre os clones, apresentando também um baixo valor de resíduo de fundo e ausência de interação entre clone e membrana.

* A análise da expressão gênica em cana-de-açúcar, em resposta à indução pela herbivoria causada pela lagarta Diatraea saccharalis, apontou 246 genes identificados na variedade susceptível (SP80-3280), enquanto 334 foram identificados na variedade tolerante (SP81-3250).

* Para ambas variedades, a classe gênica menos representativa foi a de proteínas de armazenamento e a mais representada foi a de resposta ao estresse.

* Aproximadamente $50 \%$ dos genes responsivos a herbivoria foram comuns às variedades tolerantes e susceptíveis.

* Nas duas variedades o tempo de 6 horas de avaliação do experimento apresentou um maior número de genes responsivos a herbivoria. 
* A variedade tolerante apresentou tanto o maior número de genes induzidos como também o maior em genes reprimidos, notadamente nas etapas iniciais de exposição à lagarta, podendo ser este um mecanismo genético associado à resistência de plantas às pragas. 
ANEXOS 
ANEXO A - PLACA SCGD

A01:SCSGAD1005F12 A02:SCJLFL4100E03 A03:SCQSAD1057B12 A04:SCEQFL5050C02 A05:SCRUAD1131F04 A06:SCCCFL5057C01 A07:SCEPAM1015D03 A08:SCAGFL8013D06 A09:SCBFAM2021B05 A10:SCRFHR1009A01 A11:SCRFAM2074G07 A12:SCSBHR1052C05 A13:SCSGAM2106H05 A14:SCVPLB1020A09 A15:SCCCCL4015B02 A16:SCCCLB2003F07 A17:SCMCCL6058E02 A18:SCPRLB2028D06 A19:SCUTFL1059C04 A20:SCBFLR1005D10 A21:SCRLFL3004B10 A22:SCRFLR1055H03 A23:SCRUFL3068B02 A24:SCACLR2007D05 B01:SCCCNR1004D08 B02:SCUTRZ3105B04 B03:SCJLRT1014F02 B04:SCBGSB1029A08 B05:SCQGRT1038F01 B06:SCQGSB1083E01 B07:SCBFRT1068F03 B08:SCEPSB1135A06 B09:SCQSRT2033F06 B10:SCQGSD1044D07 B11:SCAGRT2040B07 B12:SCCCSD1093E04 B13:SCVPRT2081C04 B14:SCJLST1021G01 B15:SCCCRT3002H12 B16:SCSFST3074C01 B17:SCPRRT3026B03
B18:SCRLST3165D07 B19:SCVPRT3086E09 B20:SCJFAD1013H07 B21:SCBFRZ2017H07 B22:SCSGAD1009A05 B23:SCEZRZ3051H10 B24:SCUTAD1030E06 C01:SCSGAD1009F02 C02:SCJLFL4100D06 C03:SCQSAD1056G10 C04:SCRFFL5034F09 C05:SCSFAD1125E10 C06:SCEZFL5086F01 C07:SCEPAM1023F09 C08:SCRFFL8037C01 C09:SCQGAM2026D02 C10:SCJFHR1033F03 C11:SCVPAM2067B04 C12:SCEZHR1086B06 C13:SCRFAM2127F03 C14:SCVPHR1095C03 C15:SCCCCL6001A04 C16:SCRULB1061C02 C17:SCSGCL6072G02 C18:SCRLLB2033G11 C19:SCJLFL1051A09 C20:SCEZLR1031G08 C21:SCCCFL3001G02 C22:SCJLLR1107G02 C23:SCCCFL4002C10 C24:SCQGLR2025E03 D01:SCJFRT1005D06 D02:SCSBRZ3124H08 D03:SCEQRT1025H04 D04:SCACSB1035C04 D05:SCQGRT1042E04 D06:SCRUSB1078A12 D07:SCBGRT1052A04 D08:SCEPSB1128C08 D09:SCQSRT2033F09 D10:SCUTSD1028D09
D11:SCEPRT2045F01 D12:SCCCSD1C02F09 D13:SCMCRT2087A08 D14:SCJFST1047B01 D15:SCCCRT3005B09 D16:SCSBST3095E04 D17:SCEQRT3018B04 D18:SCCCST3C10E07 D19:SCBFRT3094E10 D20:SCEQAD1016D03 D21:SCVPRZ2036B05 D22SCJFAD1014B07 D23:SCEPRZ3046D07 D24:SCEQAD1016E12 E01:SCUTAD1031C08 E02:SCSGFL4189F01 E03:SCRUAD1063E10 E04:SCEQFL5044A03 E05:SCSFAD1123E10 E06:SCSGFL5C04B02 E07:SCEPAM1051D07 E08:SCMCFL8030G03 E09:SCBFAM2021D01 E10:SCQSHR1021D08 E11:SCVPAM2069B10 E12:SCEZHR1087E06 E13:SCRFAM2131A09 E14:SCEZLB1010C02 E15:SCACCL6010A10 E16:SCCCLB2008H02 E17:SCVPCL6064B05 E18:SCVPLB2086E09 E19:SCVPFL1068G07 E20:SCUTLR1037C05 E21:SCCCFL3003E06 E22:SCQGLR1088H10 E23:SCRLFL4004C05 E24:SCJFLR2035H04 F01:SCJLRT1020E06 F02:SCRLRZ3116E01 F03:SCQGRT1039E01 
F04:SCBFSB1045E10 F05:SCBGRT1055E08 F06:SCSBSB1095G08 F07:SCBFRT1070B04 F08:SCACSB1125B12 F09:SCEQRT2026D05 F10:SCRFSD1023G05 F11:SCAGRT2042A09 F12:SCEQSD1077F10 F13:SCMCRT2088A04 F14:SCMCST1052A06 F15:SCCCRT3003E05 F16:SCBGST3104D08 F17:SCRFRT3058D04 F18:SCCCST3C02H02 F19:SCEPRZ1011G10 F20:SCACAD1038A11 F21:SCVPRZ3025A03 F22:SCBGAD1025D02 F23:SCRURZ3082B02 F22:SCJFAD1010C06 G01:SCUTAD1034C12 G02:SCCCFL5003F09 G03:SCRUAD1063C06 G04:SCEQFL5044F03 G05:SCSBAD1126C01 G06:SCEZFL5090G08 G07:SCEPAM1053E12 G08:SCQGHR1013D01 G09:SCQGAM2028G06 G10:SCJFHR1030B02 G11:SCQSAM2101D03 G12:SCEZHR1087H12 G13:SCCCCL3120B10 G14:SCEPLB1044E11 G15:SCAGCL6016E06 G16:SCBGLB2015H05 G17:SCCCCL6C06G06 G18:SCBFLB2092E08 G19:SCRUFL1114A12 G20:SCBFLR1039C08 G21:SCJLFL3015D09 G22:SCACLR1127G10 G23:SCJFFL3C08E06 G24:SCSGLV1007G11
H01:SCEQRT1026E05 H02:SCSBRZ3125A10 H03:SCBGRT1046F02 H04:SCSFSB1072C07 H05:SCBGRT1049H04 H06:SCSFSB1102C09 H07:SCRURT2014D11 H08:SCQGSB1141E04 H09:SCAGRT2039D08 H10:SCBGSD1052D05 H11:SCSGRT2061C02 H12:SCBFSD2038B09 H13:SCEQRT2101D05 H14:SCRFST1044F03 H15:SCSBRT3039E08 H16:SCUTST3129E03 H17:SCBGRT3075E02 H18:SCJFAD1013E04 H19:SCCCRZ2003A03 H20:SCJFAD1010F07 H21:SCVPRZ3027C09 H22:SCCCAD1001C08 H23:SCUTRZ3070E07 H24:SCACAD1038C10 I01:SCACAD1038F12 102:SCSGFL4196D02 103:SCEZAD1078B05 104:SCRFFL5043A01 105:SCRLAM1007D07 106:SCEZFL5085C06 107:SCJLAM1062A07 108:SCQGHR1012F03 109:SCRLAM2052C05 110:SCSFHR1045B07 111:SCJLAM2092B09 112:SCSGHR1072F02 113:SCCCCL3120D10 114:SCQGLB1027G09 115:SCAGCL6016G06 I16:SCEQLB2016C06 117:SCSFCL6066C07 I18:SCBGLB2074B05 119:SCRUFL1116F03 120:SCEZLR1031F04 121:SCAGFL3025A11
I22:SCBGLR1112G01 123:SCBGFL4055B08 124:SCCCLR2C02D04 J01:SCJLRT1015D05 J02:SCSGSB1005H05 J03:SCQGRT1041A06 J04:SCUTSB1073D09 J05:SCBFRT1068D06 J06:SCMCSB1108C01 J07:SCRURT2011C12 J08:SCQGSB1141F03 J09:SCJFRT2055F06 J10:SCMCSD1059D07 J11:SCSGRT2062D07 J12:SCBFSD2035E07 J13:SCMCRT2104C02 J14:SCMCST1050B09 J15:SCSBRT3038F01 J16:SCEZST3147G12 J17:SCRURT3061H09 J18:SCCCAD1004H02 J19:SCJLRZ102OH06 J20:SCSGAD1006A11 J21:SCVPRZ3025F04 J22:SCSGAD1009D03 J23:SCJLRZ3074D04 J24:SCRFAD1021H07 K01:SCUTAD1034A10 K02:SCMCFL5007C04 K03:SCBFAD1096D10 K04:SCEQFL5052B07 K05:SCJFAD1C11C05 K06:SCQGFL8015B01 K07:SCVPAM1058F05 K08:SCAGHR1016A10 K09:SCEZAM2035B12 K10:SCSBHR1056B11 K11:SCSGAM2103C03 K12:SCVPHR1090F01 K13:SCCCCL3001F02 K14:SCQGLB1029A12 K15:SCACCL6007C04 K16:SCPILB2024H06 K17:SCCCCL7C02B09 K18:SCJLLB2076C12 
K19:SCQSFL1129A07 K20:SCEQLR1029B05 K21:SCQSFL3034B10 K22:SCUTLR2008H11 K23:SCRLFL4058B01 K24:SCSGLV1013A05 L01:SCJLRT1015B03 L02:SCJFRZ3C05G02 L03:SCQSRT1036G11 L04:SCSFSB1069D05 L05:SCBGRT1052C01 L06:SCSFSB1103F10 L07:SCCCRT2004A03 L08:SCACSD1016E07 L09:SCJFRT2056F05 L10:SCEPSD1071B01 L11:SCVPRT2084E10 L12:SCMCSD2059H09 L13:SCCCRT3006D09 L14:SCQSST1040F12 L15:SCSBRT3040B04 L16:SCEZST3149F10 L17:SCQSRT3054H12 L18:SCSGAD1005A10 L19:SCJFRZ2033D06 L20:SCJFAD1012A08 L21:SCEQRZ3020B12 L22:SCRFAD1021G08 L23:SCSGRZ3063E01 L24:SCCCAD1003G06 M01:SCUTAD1030D06 M02:SCVPFL4C09C05 M03:SCRLAD1100F12 M04:SCCCFL5060B07 M05:SCRLAD1140C02 M06:SCQGFL8014C11 M07:SCJFAM1067F05 M08:SCRFHR1009D09 M09:SCEZAM2061C09 M10:SCSBHR1051H04 M11:SCAGAM2123E05 M12:SCVPHR1094E03
M13:SCCCCL3002E11 M14:SCQSLB1050B07 M15:SCEPCL6025G08 M16:SCQGLB2041B08 M17:SCRLFL1009B11 M18:SCMCLB2081C01 M19:SCQSFL1121G10 M20:SCRLLR1059G03 M21:SCQGFL3057F08 M22:SCVPLR2012F05 M23:SCRLFL4059G09 M24:SCQGLV1015E10 N01:SCJLRT1016G06 N02:SCSGSB1005A06 N03:SCBGRT1046D11 N04:SCEZSB1090H09 N05:SCBGRT1049B06 N06:SCSFSB1102B07 N07:SCQSRT2033C12 N08:SCCCSD1001D05 N09:SCEPRT2045C03 N10:SCSBSD1057C05 N11:SCEQRT2095B10 N12:SCEPSD2070C10 N13:SCCCRT2C02A08 N14:SCVPST1060H12 N15:SCRLRT3034F06 N16:SCUTST3152C01 N17:SCJFRZ1005D12 N18:SCBGAD1027E01 N19:SCJFRZ2015B03 N20:SCBGAD1028G08 N21:SCACRZ3033H01 N22:SCSGAD1005F12 N23:SCEQRZ3093G04 N24:SCJFAD1014E03 O01:SCBFAD1048D03 O02:SCACFL5028C04 O03:SCRLAD1100A11 004:SCCCFL5065C01 O05:SCSGAD1144B06 O06:SCAGFL8012D03
O07:SCCCAM2002D04 O08:SCRFHR1005C09 O09:SCSGAM2079B12 O10:SCBGHR1057E05 O11:SCAGAM2122B09 O12:SCRUHR1077B04 O13:SCCCCL4010E02 014:SCACLB1048C02 O15:SCMCCL6060H03 O16:SCQGLB2042B04 017:SCJLFL1053G11 O18:SCEZLR1009E06 O19:SCBFFL1142C04 O20:SCEPLR1051B08 O21:SCQGFL3053E04 O22:SCUTLR2008F06 O23:SCQGFL4076B03 O24:SCCCRT1001G12 P01:SCEQRT1024F02 P02:SCRFSB1021F11 P03:SCQSRT1037H06 P04:SCEZSB1093B12 P05:SCBGRT1053H02 P06:SCACSB1120C03 P07:SCEZRT2020A03 P08:SCEPSD1005E12 P09:SCEPRT2044B07 P10:SCEZSD1080B02 P11:SCEQRT2096B12 P12:SCCCST1006B08 P13:SCCCRT3002G10 P14:SCSBST3096E03 P15:SCQGRT3045E08 P16:SCCCST3144E06 P17:SCEQRT3C01C05 P18:SCSGAD1008B04 P19:SCJFRZ2030D03 P20:SCJFAD1012F11 P21:SCEZRZ3050E02 P22:SCJFAD1011A09 P23:SCEZRZ3098B06 P24:SCBGAD1026F02 
ANEXO B - PLACA SCUG 065

A01:SCQGLR1087F08 A02:SCEQLR1094D08 A03:SCQGLR1088C08 A04:SCEQLR1094H01 A05:SCQSLR1089A04 A06:SCBGLR1095E02 A07:SCQSLR1089F02 A08:SCBGLR1095G11 A09:SCQSLR1089H11 A10:SCBGLR1096C06 A11:SCQSLR1090H11 A12:SCBGLR1097A01 A13:SCEQLR1091D06 A14:SCBGLR1097E04 A15:SCEQLR1091G10 A16:SCBGLR1097G12 A17:SCEQLR1092A11 A18:SCBGLR1098G06 A19:SCEQLR1092H02 A20:SCBGLR1099C01 A21:SCEQLR1093D03 A22:SCBGLR1099G07 A23:SCEQLR1093H01 A24:SCBGLR1100D06 B01:SCBGLR1100H06 B02:SCJLLR1106B10 B03:SCJLLR1101D12 B04:SCJLLR1106F01 B05:SCJLLR1101G12 B06:SCJLLR1107B12 B07:SCJLLR1102D06 B08:SCJLLR1107F04 B09:SCJLLR1102G08 B10:SCJLLR1107H04 B11:SCJLLR1103D06 B12:SCJLLR1108C11 B13:SCJLLR1103G06 B14:SCJLLR1108G11 B15:SCJLLR1104A08 B16:SCRLLR1109C08
B17:SCJLLR1104E04 B18:SCRLLR1109F07 B19:SCJLLR1104G10 B20:SCRLLR1109H06 B21:SCJLLR1105C12 B22:SCRLLR1110C03 B23:SCJLLR1105G12 B24:SCRLLR1110G08 C01:SCQGLR1087F12 C02:SCEQLR1094E06 C03:SCQGLR1088C10 C04:SCEQLR1094H08 C05:SCQSLR1089A05 C06:SCBGLR1095E08 C07:SCQSLR1089F09 C08:SCBGLR1095H05 C09:SCQSLR1090A07 C10:SCBGLR1096C11 C11:SCEQLR1091B02 C12:SCBGLR1097A04 C13:SCEQLR1091D10 C14:SCBGLR1097E05 C15:SCEQLR1091H01 C16:SCBGLR1097H10 C17:SCEQLR1092B01 C18:SCBGLR1098G11 C19:SCEQLR1093A01 C20:SCBGLR1099C04 C21:SCEQLR1093D07 C22:SCBGLR1100A04 C23:SCEQLR1093H08 C24:SCBGLR1100D12 D01:SCJLLR1101A01 D02:SCJLLR1106C06 D03:SCJLLR1101E03 D04:SCJLLR1106G01 D05:SCJLLR1102A03 D06:SCJLLR1107C01 D07:SCJLLR1102E03 D08:SCJLLR1107F10
D09:SCJLLR1102H01 D10:SCJLLR1107H12 D11:SCJLLR1103D09 D12:SCJLLR1108D06 D13:SCJLLR1103G12 D14:SCJLLR1108H09 D15:SCJLLR1104B07 D16:SCRLLR1109C12 D17:SCJLLR1104E05 D18:SCRLLR1109F09 D19:SCJLLR1104H01 D20:SCRLLR1109H08 D21:SCJLLR1105F01 D22:SCRLLR1110D03 D23:SCJLLR1105H03 D24:SCRLLR1111A01 E01:SCQGLR1087G09 E02:SCEQLR1094F02 E03:SCQGLR1088D01 E04:SCBGLR1095A03 E05:SCQSLR1089B07 E06:SCBGLR1095E10 E07:SCQSLR1089F10 E08:SCBGLR1095H08 E09:SCQSLR1090D08 E10:SCBGLR1096C12 E11:SCEQLR1091C03 E12:SCBGLR1097A09 E13:SCEQLR1091D12 E14:SCBGLR1097E06 E15:SCEQLR1091H03 E16:SCBGLR1098A11 E17:SCEQLR1092B03 E18:SCBGLR1098G12 E19:SCEQLR1093A03 E20:SCBGLR1099D01 E21:SCEQLR1093E02 E22:SCBGLR1100A05 E23:SCEQLR1093H10 E24:SCBGLR1100E01 
F01:SCJLLR1101A02 F02:SCJLLR1106C09 F03:SCJLLR1101E10 F04:SCJLLR1106G08 F05:SCJLLR1102B01 F06:SCJLLR1107C02 F07:SCJLLR1102E07 F08:SCJLLR1107F11 F09:SCJLLR1102H07 F10:SCJLLR1108A10 F11:SCJLLR1103D10 F12:SCJLLR1108D08 F13:SCJLLR1103H02 F14:SCRLLR1109A11 F15:SCJLLR1104B09 F16:SCRLLR1109D04 F17:SCJLLR1104E11 F18:SCRLLR1109F10 F19:SCJLLR1104H11 F20:SCRLLR1109H11 F21:SCJLLR1105F08 F22:SCRLLR1110D06 F23:SCJLLR1105H04 F24:SCRLLR1111A06 G01:SCQGLR1087H03 G02:SCEQLR1094F04 G03:SCQGLR1088F07 G04:SCBGLR1095B01 G05:SCQSLR1089B09 G06:SCBGLR1095F09 G07:SCQSLR1089F11 G08:SCBGLR1096A03 G09:SCQSLR1090E01 G10:SCBGLR1096D04 G11:SCEQLR1091C05 G12:SCBGLR1097B02 G13:SCEQLR1091E03 G14:SCBGLR1097E10 G15:SCEQLR1091H06 G16:SCBGLR1098B04 G17:SCEQLR1092C01 G18:SCBGLR1098H04 G19:SCEQLR1093A05 G20:SCBGLR1099D10 G21:SCEQLR1093E09
G22:SCBGLR1100A06 G23:SCEQLR1093H11 G24:SCBGLR1100F03 H01:SCJLLR1101A04 H02:SCJLLR1106C11 H03:SCJLLR1101E11 H04:SCJLLR1106G11 H05:SCJLLR1102B03 H06:SCJLLR1107C03 H07:SCJLLR1102E08 H08:SCJLLR1107G02 H09:SCJLLR1103A11 H10:SCJLLR1108A12 H11:SCJLLR1103E05 H12:SCJLLR1108D10 H13:SCJLLR1103H06 H14:SCRLLR1109B04 H15:SCJLLR1104C06 H16:SCRLLR1109D12 H17:SCJLLR1104F03 H18:SCRLLR1109G03 H19:SCJLLR1105A01 H20:SCRLLR1110A03 H21:SCJLLR1105F12 H22:SCRLLR1110D07 H23:SCJLLR1105H10 H24:SCRLLR1111B01 101:SCQGLR1087H04 102:SCEQLR1094G05 103:SCQGLR1088G05 104:SCBGLR1095C03 105:SCQSLR1089C01 106:SCBGLR1095F10 107:SCQSLR1089G09 108:SCBGLR1096A06 109:SCQSLR1090E04 I10:SCBGLR1096D08 I11:SCEQLR1091C06 112:SCBGLR1097D06 I13:SCEQLR1091E06 I14:SCBGLR1097F03 I15:SCEQLR1092A01 116:SCBGLR1098B07 I17:SCEQLR1092C02 I18:SCBGLR1099A08
I19:SCEQLR1093A06 120:SCBGLR1099E02 121:SCEQLR1093E12 122:SCBGLR1100A08 123:SCEQLR1093H12 124:SCBGLR1100F10 J01:SCJLLR1101B05 J02:SCJLLR1106D03 J03:SCJLLR1101F03 J04:SCJLLR1106G12 J05:SCJLLR1102B05 J06:SCJLLR1107D12 J07:SCJLLR1102F01 J08:SCJLLR1107G03 J09:SCJLLR1103B01 J10:SCJLLR1108B10 J11:SCJLLR1103E06 J12:SCJLLR1108D11 J13:SCJLLR1103H09 J14:SCRLLR1109B07 J15:SCJLLR1104C09 J16:SCRLLR1109E02 J17:SCJLLR1104F08 J18:SCRLLR1109G04 J19:SCJLLR1105A06 J20:SCRLLR1110B01 J21:SCJLLR1105G04 J22:SCRLLR1110D10 J23:SCJLLR1106A07 J24:SCRLLR1111B02 K01:SCQGLR1087H10 K02:SCEQLR1094G07 K03:SCQGLR1088G10 K04:SCBGLR1095D06 K05:SCQSLR1089D09 K06:SCBGLR1095G03 K07:SCQSLR1089H02 K08:SCBGLR1096A12 K09:SCQSLR1090E05 K10:SCBGLR1096D09 K11:SCEQLR1091C10 K12:SCBGLR1097D11 K13:SCEQLR1091F09 K14:SCBGLR1097F08 K15:SCEQLR1092A03 
K16:SCBGLR1098C07 K17:SCEQLR1092D01 K18:SCBGLR1099A10 K19:SCEQLR1093B10 K20:SCBGLR1099E10 K21:SCEQLR1093G02 K22:SCBGLR1100A10 K23:SCEQLR1094A06 K24:SCBGLR1100F12 L01:SCJLLR1101B06 L02:SCJLLR1106E04 L03:SCJLLR1101F04 L04:SCJLLR1107B02 L05:SCJLLR1102B06 L06:SCJLLR1107E01 L07:SCJLLR1102F10 L08:SCJLLR1107G06 L09:SCJLLR1103C09 L10:SCJLLR1108C03 L11:SCJLLR1103E11 L12:SCJLLR1108E11 L13:SCJLLR1103H12 L14:SCRLLR1109B09 L15:SCJLLR1104C12 L16:SCRLLR1109F02 L17:SCJLLR1104G01 L18:SCRLLR1109G06 L19:SCJLLR1105B04 L20:SCRLLR1110B04 L21:SCJLLR1105G05 L22:SCRLLR1110F04 L23:SCJLLR1106A09 L24:SCRLLR1111C05 M01:SCQGLR1088A12 M02:SCEQLR1094G10 M03:SCQGLR1088H07 M04:SCBGLR1095D07 M05:SCQSLR1089D10 M06:SCBGLR1095G05 M07:SCQSLR1089H04 M08:SCBGLR1096B03 M09:SCQSLR1090E07 M10:SCBGLR1096H04
M11:SCEQLR1091D03 M12:SCBGLR1097D12 M13:SCEQLR1091G01 M14:SCBGLR1097F10 M15:SCEQLR1092A04 M16:SCBGLR1098D05 M17:SCEQLR1092E10 M18:SCBGLR1099B07 M19:SCEQLR1093B11 M20:SCBGLR1099F12 M21:SCEQLR1093G07 M22:SCBGLR1100B04 M23:SCEQLR1094B03 M24:SCBGLR1100G01 N01:SCJLLR1101B08 N02:SCJLLR1106E05 N03:SCJLLR1101F10 N04:SCJLLR1107B03 N05:SCJLLR1102B07 N06:SCJLLR1107E12 N07:SCJLLR1102G03 N08:SCJLLR1107G08 N09:SCJLLR1103C11 N10:SCJLLR1108C05 N11:SCJLLR1103F03 N12:SCJLLR1108F11 N13:SCJLLR1104A02 N14:SCRLLR1109C02 N15:SCJLLR1104D02 N16:SCRLLR1109F03 N17:SCJLLR1104G04 N18:SCRLLR1109G08 N19:SCJLLR1105C01 N20:SCRLLR1110B05 N21:SCJLLR1105G06 N22:SCRLLR1110G02 N23:SCJLLR1106A11 N24:SCRLLR1111D02 O01:SCQGLR1088B08 O02:SCEQLR1094G12 O03:SCQGLR1088H10 O04:SCBGLR1095E01 O05:SCQSLR1089E05
O06:SCBGLR1095G10 O07:SCQSLR1089H09 O08:SCBGLR1096B04 O09:SCQSLR1090G05 O10:SCBGLR1096H10 O11:SCEQLR1091D04 O12:SCBGLR1097E02 O13:SCEQLR1091G03 O14:SCBGLR1097G08 O15:SCEQLR1092A06 O16:SCBGLR1098G03 O17:SCEQLR1092F03 O18:SCBGLR1099B11 O19:SCEQLR1093C02 O20:SCBGLR1099G05 O21:SCEQLR1093G08 O22:SCBGLR1100C12 O23:SCEQLR1094C08 O24:SCBGLR1100G05 P01:SCJLLR1101C12 P02:SCJLLR1106E07 P03:SCJLLR1101G03 P04:SCJLLR1107B07 P05:SCJLLR1102B08 P06:SCJLLR1107F01 P07:SCJLLR1102G07 P08:SCJLLR1107G11 P09:SCJLLR1103D02 P10:SCJLLR1108C07 P11:SCJLLR1103F08 P12:SCJLLR1108G05 P13:SCJLLR1104A05 P14:SCRLLR1109C06 P15:SCJLLR1104D05 P16:SCRLLR1109F06 P17:SCJLLR1104G07 P18:SCRLLR1109G11 P19:SCJLLR1105C05 P20:SCRLLR1110B12 P21:SCJLLR1105G08 P22:SCRLLR1110G05 P23:SCJLLR1106B01 P24:SCRLLR1111D12 
ANEXO C - PLACA SCUG 066

A01:SCRLLR1111E05 A02:SCBGLR1117D09 A03:SCRLLR1111H01 A04:SCBGLR1118B05 A05:SCBGLR1112D10 A06:SCBGLR1118F08 A07:SCBGLR1112H05 A08:SCBGLR1119E06 A09:SCBGLR1113E08 A10:SCBGLR1119H10 A11:SCBGLR1114A02 A12:SCBGLR1120C02 A13:SCBGLR1114D12 A14:SCBGLR1120G04 A15:SCBGLR1114G07 A16:SCCCLR1121D03 A17:SCBGLR1115B08 A18:SCMCLR1122B06 A19:SCBGLR1115G03 A20:SCMCLR1122D09 A21:SCBGLR1116D01 A22:SCMCLR1122H07 A23:SCBGLR1116H10 A24:SCMCLR1123E05 B01:SCMCLR1124B01 B02:SCACLR1129H11 B03:SCMCLR1124E09 B04:SCACLR1130C06 B05:SCMCLR1125A01 B06:SCACLR1130F07 B07:SCMCLR1125E02 B08:SCRLLR1131C09 B09:SCMCLR1125H02 B10:SCRLLR1131G03 B11:SCACLR1126C11 B12:SCACLR1132B03 B13:SCACLR1126F06 B14:SCACLR1132E02 B15:SCACLR1127A08 B16:SCACLR1132G02
B17:SCACLR1127F11 B18:SCCCLR1C01D08 B19:SCACLR1128C02 B20:SCCCLR1C03G05 B21:SCACLR1128F11 B22:SCCCLR1C04H05 B23:SCACLR1129C03 B24:SCCCLR1C06A07 C01:SCRLLR1111E06 C02:SCBGLR1117E04 C03:SCRLLR1111H07 C04:SCBGLR1118B09 C05:SCBGLR1112D11 C06:SCBGLR1118G09 C07:SCBGLR1113A07 C08:SCBGLR1119E11 C09:SCBGLR1113E12 C10:SCBGLR1120A04 C11:SCBGLR1114A03 C12:SCBGLR1120C03 C13:SCBGLR1114E02 C14:SCBGLR1120G07 C15:SCBGLR1114G08 C16:SCCCLR1121D04 C17:SCBGLR1115C02 C18:SCMCLR1122B09 C19:SCBGLR1115H09 C20:SCMCLR1122D11 C21:SCBGLR1116D02 C22:SCMCLR1123B02 C23:SCBGLR1117A01 C24:SCMCLR1123E06 D01:SCMCLR1124B05 D02:SCACLR1130A03 D03:SCMCLR1124F01 D04:SCACLR1130C08 D05:SCMCLR1125A03 D06:SCACLR1130G01 D07:SCMCLR1125E04 D08:SCRLLR1131D06
D09:SCMCLR1125H05 D10:SCRLLR1131G06 D11:SCACLR1126D01 D12:SCACLR1132B04 D13:SCACLR1126F10 D14:SCACLR1132E03 D15:SCACLR1127D01 D16:SCACLR1132G12 D17:SCACLR1127G10 D18:SCCCLR1C01G12 D19:SCACLR1128C03 D20:SCCCLR1C04A01 D21:SCACLR1128G02 D22:SCCCLR1C04H10 D23:SCACLR1129D02 D24:SCCCLR1C06A09 E01:SCRLLR1111F02 E02:SCBGLR1117E07 E03:SCBGLR1112A01 E04:SCBGLR1118C01 E05:SCBGLR1112E12 E06:SCBGLR1119B09 E07:SCBGLR1113A12 E08:SCBGLR1119F04 E09:SCBGLR1113F04 E10:SCBGLR1120A05 E11:SCBGLR1114A09 E12:SCBGLR1120C07 E13:SCBGLR1114E03 E14:SCBGLR1120G08 E15:SCBGLR1114G11 E16:SCCCLR1121D05 E17:SCBGLR1115C04 E18:SCMCLR1122B12 E19:SCBGLR1115H12 E20:SCMCLR1122E06 E21:SCBGLR1116D07 E22:SCMCLR1123B04 E23:SCBGLR1117A03 E24:SCMCLR1123E07 
F01:SCMCLR1124B11 F02:SCACLR1130A07 F03:SCMCLR1124G01 F04:SCACLR1130D02 F05:SCMCLR1125A07 F06:SCACLR1130H02 F07:SCMCLR1125E09 F08:SCRLLR1131E01 F09:SCACLR1126A04 F10:SCRLLR1131G09 F11:SCACLR1126D04 F12:SCACLR1132B05 F13:SCACLR1126G08 F14:SCACLR1132E07 F15:SCACLR1127D05 F16:SCACLR1132H04 F17:SCACLR1128A01 F18:SCCCLR1C02E01 F19:SCACLR1128C08 F20:SCCCLR1C04A06 F21:SCACLR1128G08 F22:SCCCLR1C04H11 F23:SCACLR1129E09 F24:SCCCLR1C06A12 G01:SCRLLR1111F03 G02:SCBGLR1117F03 G03:SCBGLR1112A08 G04:SCBGLR1118C02 G05:SCBGLR1112F04 G06:SCBGLR1119B11 G07:SCBGLR1113B09 G08:SCBGLR1119G03 G09:SCBGLR1113F06 G10:SCBGLR1120A08 G11:SCBGLR1114B01 G12:SCBGLR1120D03 G13:SCBGLR1114E09 G14:SCBGLR1120G10 G15:SCBGLR1114G12 G16:SCCCLR1121D06 G17:SCBGLR1115C11 G18:SCMCLR1122C03 G19:SCBGLR1116A10 G20:SCMCLR1122E09 G21:SCBGLR1116F04
G22:SCMCLR1123B11 G23:SCBGLR1117A09 G24:SCMCLR1123E09 H01:SCMCLR1124C03 H02:SCACLR1130A09 H03:SCMCLR1124G02 H04:SCACLR1130D06 H05:SCMCLR1125A10 H06:SCACLR1130H05 H07:SCMCLR1125F01 H08:SCRLLR1131E04 H09:SCACLR1126A09 H10:SCACLR1132A02 H11:SCACLR1126D05 H12:SCACLR1132C07 H13:SCACLR1126G09 H14:SCACLR1132E12 H15:SCACLR1127D09 H16:SCCCLR1C01A04 H17:SCACLR1128A03 H18:SCCCLR1C02F11 H19:SCACLR1128C10 H20:SCCCLR1C04A07 H21:SCACLR1128H03 H22:SCCCLR1C05A01 H23:SCACLR1129F12 H24:SCCCLR1C06B11 101:SCRLLR1111F05 102:SCBGLR1117F05 103:SCBGLR1112B09 104:SCBGLR1118C07 105:SCBGLR1112F10 106:SCBGLR1119C06 107:SCBGLR1113C01 108:SCBGLR1119G04 109:SCBGLR1113G03 I10:SCBGLR1120A10 I11:SCBGLR1114B12 112:SCBGLR1120D04 113:SCBGLR1114E11 I14:SCBGLR1120G11 I15:SCBGLR1114H02 I16:SCCCLR1121F01 117:SCBGLR1115D05 I18:SCMCLR1122D02
I19:SCBGLR1116A12 120:SCMCLR1122F09 121:SCBGLR1116F06 122:SCMCLR1123C04 123:SCBGLR1117B12 I24:SCMCLR1123E11 J01:SCMCLR1124C06 J02:SCACLR1130B05 J03:SCMCLR1124G08 J04:SCACLR1130D12 J05:SCMCLR1125B03 J06:SCACLR1130H06 J07:SCMCLR1125F11 J08:SCRLLR1131E07 J09:SCACLR1126B09 J10:SCACLR1132A05 J11:SCACLR1126D09 J12:SCACLR1132C09 J13:SCACLR1126H11 J14:SCACLR1132F04 J15:SCACLR1127D10 J16:SCCCLR1C01A11 J17:SCACLR1128A09 J18:SCCCLR1C02H03 J19:SCACLR1128C11 J20:SCCCLR1C04B08 J21:SCACLR1128H06 J22:SCCCLR1C05E10 J23:SCACLR1129G06 J24:SCCCLR1C06C03 K01:SCRLLR1111F07 K02:SCBGLR1118A08 K03:SCBGLR1112B12 K04:SCBGLR1118E12 K05:SCBGLR1112G01 K06:SCBGLR1119D02 K07:SCBGLR1113C12 K08:SCBGLR1119H02 K09:SCBGLR1113G08 K10:SCBGLR1120B02 K11:SCBGLR1114C08 K12:SCBGLR1120E06 K13:SCBGLR1114F05 K14:SCBGLR1120G12 K15:SCBGLR1114H06 
K16:SCCCLR1121H02 K17:SCBGLR1115D07 K18:SCMCLR1122D03 K19:SCBGLR1116B10 K20:SCMCLR1122G01 K21:SCBGLR1116G04 K22:SCMCLR1123C11 K23:SCBGLR1117C03 K24:SCMCLR1123F12 L01:SCMCLR1124C09 L02:SCACLR1130B10 L03:SCMCLR1124H05 L04:SCACLR1130E04 L05:SCMCLR1125B04 L06:SCACLR1130H09 L07:SCMCLR1125F12 L08:SCRLLR1131F03 L09:SCACLR1126B11 L10:SCACLR1132A07 L11:SCACLR1126E04 L12:SCACLR1132D05 L13:SCACLR1127A05 L14:SCACLR1132F08 L15:SCACLR1127D12 L16:SCCCLR1C01B12 L17:SCACLR1128A10 L18:SCCCLR1C02H09 L19:SCACLR1128D03 L20:SCCCLR1C04C02 L21:SCACLR1128H07 L22:SCCCLR1C05F12 L23:SCACLR1129G09 L24:SCCCLR1C06D07 M01:SCRLLR1111F08 M02:SCBGLR1118A11 M03:SCBGLR1112C06 M04:SCBGLR1118F03 M05:SCBGLR1112G08 M06:SCBGLR1119D05 M07:SCBGLR1113D01 M08:SCBGLR1119H06 M09:SCBGLR1113H02 M10:SCBGLR1120B04
M11:SCBGLR1114C09 M12:SCBGLR1120E11 M13:SCBGLR1114G02 M14:SCCCLR1121A06 M15:SCBGLR1115A04 M16:SCMCLR1122A06 M17:SCBGLR1115E03 M18:SCMCLR1122D04 M19:SCBGLR1116C04 M20:SCMCLR1122G02 M21:SCBGLR1116G06 M22:SCMCLR1123D10 M23:SCBGLR1117C05 M24:SCMCLR1123H04 N01:SCMCLR1124D07 N02:SCACLR1130C01 N03:SCMCLR1124H07 N04:SCACLR1130E10 N05:SCMCLR1125C06 N06:SCRLLR1131A05 N07:SCMCLR1125G01 N08:SCRLLR1131F07 N09:SCACLR1126C01 N10:SCACLR1132A10 N11:SCACLR1126E11 N12:SCACLR1132D07 N13:SCACLR1127A06 N14:SCACLR1132F09 N15:SCACLR1127E11 N16:SCCCLR1C01C04 N17:SCACLR1128B12 N18:SCCCLR1C03A04 N19:SCACLR1128D10 N20:SCCCLR1C04F09 N21:SCACLR1129A11 N22:SCCCLR1C05G04 N23:SCACLR1129G11 N24:SCCCLR1C06E11 O01:SCRLLR1111G09 O02:SCBGLR1118A12 O03:SCBGLR1112C12 O04:SCBGLR1118F05 O05:SCBGLR1112H04
O06:SCBGLR1119D12 O07:SCBGLR1113D03 O08:SCBGLR1119H08 O09:SCBGLR1113H06 O10:SCBGLR1120B07 O11:SCBGLR1114C10 O12:SCBGLR1120F01 O13:SCBGLR1114G05 O14:SCCCLR1121B12 O15:SCBGLR1115A05 O16:SCMCLR1122A07 O17:SCBGLR1115E11 O18:SCMCLR1122D05 O19:SCBGLR1116C07 O20:SCMCLR1122H05 O21:SCBGLR1116H01 O22:SCMCLR1123D12 O23:SCBGLR1117C07 O24:SCMCLR1124A06 P01:SCMCLR1124D08 P02:SCACLR1130C02 P03:SCMCLR1124H11 P04:SCACLR1130F05 P05:SCMCLR1125C10 P06:SCRLLR1131C02 P07:SCMCLR1125G06 P08:SCRLLR1131F10 P09:SCACLR1126C09 P10:SCACLR1132B02 P11:SCACLR1126F01 P12:SCACLR1132D11 P13:SCACLR1127A07 P14:SCACLR1132G01 P15:SCACLR1127F05 P16:SCCCLR1C01C11 P17:SCACLR1128C01 P18:SCCCLR1C03C06 P19:SCACLR1128F07 P20:SCCCLR1C04F10 P21:SCACLR1129A12 P22:SCCCLR1C05H11 P23:SCACLR1129H08 P24:SCCCLR1C06F01 
ANEXO D - PLACA SCUG 067

A01:SCCCLR1C06F08 A02:SCCCLR2004H10 A03:SCCCLR1C07F09 A04:SCVPLR2005F05 A05:SCCCLR1C09D05 A06:SCJLLR2006A08 A07:SCCCLR1C10F06 A08:SCJLLR2006E12 A09:SCCCLR2001C07 A10:SCJLLR2006H01 A11:SCCCLR2001G12 A12:SCACLR2007B09 A13:SCCCLR2002B04 A14:SCACLR2007E07 A15:SCCCLR2002F04 A16:SCUTLR2008A12 A17:SCCCLR2003A01 A18:SCUTLR2008E10 A19:SCCCLR2003D09 A20:SCUTLR2008H03 A21:SCCCLR2004A03 A22:SCSFLR2009E05 A23:SCCCLR2004C03 A24:SCQGLR2010D06 B01:SCAGLR2011B01 B02:SCQGLR2017E02 B03:SCAGLR2011G03 B04:SCAGLR2018F12 B05:SCVPLR2012C11 B06:SCVPLR2019A05 B07:SCVPLR2012E08 B08:SCVPLR2019F01 B09:SCJLLR2013A06 B10:SCJLLR2020B05 B11:SCJLLR2013E09 B12:SCRFLR2021A07 B13:SCACLR2014D08 B14:SCRFLR2021E06 B15:SCACLR2014G09 B16:SCACLR2022A07
B17:SCUTLR2015E05 B18:SCACLR2022F05 B19:SCSFLR2016B10 B20:SCUTLR2023C05 B21:SCSFLR2016E07 B22:SCUTLR2023H01 B23:SCQGLR2017B04 B24:SCSFLR2024C07 C01:SCCCLR1C07A03 C02:SCVPLR2005A03 C03:SCCCLR1C08C03 C04:SCVPLR2005F09 C05:SCCCLR1C09E11 C06:SCJLLR2006A11 C07:SCCCLR1C11A10 C08:SCJLLR2006F04 C09:SCCCLR2001C11 C10:SCJLLR2006H11 C11:SCCCLR2001H10 C12:SCACLR2007B11 C13:SCCCLR2002B12 C14:SCACLR2007E09 C15:SCCCLR2002F06 C16:SCUTLR2008B01 C17:SCCCLR2003A09 C18:SCUTLR2008E12 C19:SCCCLR2003E12 C20:SCUTLR2008H11 C21:SCCCLR2004A05 C22:SCSFLR2009F06 C23:SCCCLR2004C05 C24:SCQGLR2010D10 D01:SCAGLR2011B04 D02:SCQGLR2017G06 D03:SCAGLR2011G10 D04:SCAGLR2018G04 D05:SCVPLR2012D01 D06:SCVPLR2019B10 D07:SCVPLR2012E12 D08:SCVPLR2019F04
D09:SCJLLR2013B12 D10:SCJLLR2020B06 D11:SCJLLR2013F01 D12:SCRFLR2021A10 D13:SCACLR2014E01 D14:SCRFLR2021E07 D15:SCACLR2014G12 D16:SCACLR2022A09 D17:SCUTLR2015G02 D18:SCACLR2022F07 D19:SCSFLR2016C03 D20:SCUTLR2023D03 D21:SCSFLR2016G02 D22:SCUTLR2023H07 D23:SCQGLR2017B11 D24:SCSFLR2024C09 E01:SCCCLR1C07B11 E02:SCVPLR2005B02 E03:SCCCLR1C08E02 E04:SCVPLR2005G02 E05:SCCCLR1C09H08 E06:SCJLLR2006B06 E07:SCCCLR1C11A11 E08:SCJLLR2006F05 E09:SCCCLR2001C12 E10:SCACLR2007A05 E11:SCCCLR2001H11 E12:SCACLR2007C08 E13:SCCCLR2002D06 E14:SCACLR2007E10 E15:SCCCLR2002F12 E16:SCUTLR2008C06 E17:SCCCLR2003B10 E18:SCUTLR2008F02 E19:SCCCLR2003G03 E20:SCSFLR2009A02 E21:SCCCLR2004A08 E22:SCSFLR2009F10 E23:SCCCLR2004C09 E24:SCQGLR2010G02 
F01:SCAGLR2011B05 F02:SCAGLR2018A02 F03:SCVPLR2012A05 F04:SCAGLR2018G12 F05:SCVPLR2012D03 F06:SCVPLR2019C01 F07:SCVPLR2012F03 F08:SCVPLR2019G05 F09:SCJLLR2013C01 F10:SCJLLR2020E01 F11:SCJLLR2013G02 F12:SCRFLR2021B04 F13:SCACLR2014E09 F14:SCRFLR2021F06 F15:SCUTLR2015A02 F16:SCACLR2022A12 F17:SCUTLR2015G05 F18:SCACLR2022G06 F19:SCSFLR2016D02 F20:SCUTLR2023E01 F21:SCSFLR2016G03 F22:SCUTLR2023H10 F23:SCQGLR2017C02 F24:SCSFLR2024D09 G01:SCCCLR1C07C01 G02:SCVPLR2005D03 G03:SCCCLR1C08F09 G04:SCVPLR2005G11 G05:SCCCLR1C10B05 G06:SCJLLR2006B07 G07:SCCCLR1C11C06 G08:SCJLLR2006G03 G09:SCCCLR2001D04 G10:SCACLR2007A07 G11:SCCCLR2002A04 G12:SCACLR2007C12 G13:SCCCLR2002D08 G14:SCACLR2007E11 G15:SCCCLR2002G01 G16:SCUTLR2008C12 G17:SCCCLR2003C05 G18:SCUTLR2008F03 G19:SCCCLR2003G05 G20:SCSFLR2009A05 G21:SCCCLR2004B05
G22:SCSFLR2009H03 G23:SCCCLR2004D02 G24:SCQGLR2010G04 H01:SCAGLR2011B07 H02:SCAGLR2018A05 H03:SCVPLR2012A09 H04:SCAGLR2018H04 H05:SCVPLR2012D04 H06:SCVPLR2019C10 H07:SCVPLR2012F05 H08:SCVPLR2019G12 H09:SCJLLR2013C06 H10:SCJLLR2020E05 H11:SCJLLR2013G04 H12:SCRFLR2021B05 H13:SCACLR2014E11 H14:SCRFLR2021G01 H15:SCUTLR2015A07 H16:SCACLR2022B11 H17:SCUTLR2015G12 H18:SCACLR2022G07 H19:SCSFLR2016D03 H20:SCUTLR2023E11 H21:SCSFLR2016G11 H22:SCUTLR2023H11 H23:SCQGLR2017C06 H24:SCSFLR2024E10 101:SCCCLR1C07C03 102:SCVPLR2005D05 103:SCCCLR1C08G10 104:SCVPLR2005H03 105:SCCCLR1C10B06 106:SCJLLR2006C01 107:SCCCLR1C11G01 108:SCJLLR2006G04 109:SCCCLR2001D05 110:SCACLR2007A09 111:SCCCLR2002A06 112:SCACLR2007D03 113:SCCCLR2002D10 114:SCACLR2007F07 115:SCCCLR2002G04 I16:SCUTLR2008D04 I17:SCCCLR2003C10 I18:SCUTLR2008F06
I19:SCCCLR2003H03 120:SCSFLR2009B01 121:SCCCLR2004B07 122:SCSFLR2009H11 123:SCCCLR2004D08 124:SCQGLR2010H04 J01:SCAGLR2011C02 J02:SCAGLR2018A12 J03:SCVPLR2012B03 J04:SCAGLR2018H07 J05:SCVPLR2012D12 J06:SCVPLR2019D03 J07:SCVPLR2012G04 J08:SCVPLR2019H04 J09:SCJLLR2013C09 J10:SCJLLR2020F11 J11:SCJLLR2013G07 J12:SCRFLR2021B09 J13:SCACLR2014F07 J14:SCRFLR2021G05 J15:SCUTLR2015B06 J16:SCACLR2022C03 J17:SCUTLR2015H09 J18:SCACLR2022G09 J19:SCSFLR2016D06 J20:SCUTLR2023E12 J21:SCSFLR2016H03 J22:SCSFLR2024A09 J23:SCQGLR2017C08 J24:SCSFLR2024G05 K01:SCCCLR1C07D03 K02:SCVPLR2005D11 K03:SCCCLR1C09A07 K04:SCVPLR2005H12 K05:SCCCLR1C10C03 K06:SCJLLR2006C04 K07:SCCCLR1C11G11 K08:SCJLLR2006G06 K09:SCCCLR2001G02 K10:SCACLR2007A11 K11:SCCCLR2002A09 K12:SCACLR2007D05 K13:SCCCLR2002D11 K14:SCACLR2007G11 K15:SCCCLR2002G06 
K16:SCUTLR2008D09 K17:SCCCLR2003D03 K18:SCUTLR2008G04 K19:SCCCLR2003H06 K20:SCSFLR2009B07 K21:SCCCLR2004B11 K22:SCQGLR2010A11 K23:SCCCLR2004E05 K24:SCQGLR2010H05 L01:SCAGLR2011E05 L02:SCAGLR2018B04 L03:SCVPLR2012B05 L04:SCAGLR2018H08 L05:SCVPLR2012E02 L06:SCVPLR2019D05 L07:SCVPLR2012H01 L08:SCVPLR2019H06 L09:SCJLLR2013C12 L10:SCJLLR2020G01 L11:SCJLLR2013H02 L12:SCRFLR2021D08 L13:SCACLR2014F09 L14:SCRFLR2021H11 L15:SCUTLR2015B09 L16:SCACLR2022D01 L17:SCSFLR2016A03 L18:SCACLR2022H01 L19:SCSFLR2016D09 L20:SCUTLR2023F01 L21:SCSFLR2016H10 L22:SCSFLR2024B01 L23:SCQGLR2017D04 L24:SCSFLR2024G12 M01:SCCCLR1C07E04 M02:SCVPLR2005E09 M03:SCCCLR1C09C02 M04:SCJLLR2006A02 M05:SCCCLR1C10D12 M06:SCJLLR2006C07 M07:SCCCLR2001B05 M08:SCJLLR2006G07 M09:SCCCLR2001G05 M10:SCACLR2007B03
M11:SCCCLR2002A10 M12:SCACLR2007D10 M13:SCCCLR2002E03 M14:SCUTLR2008A05 M15:SCCCLR2002H02 M16:SCUTLR2008D11 M17:SCCCLR2003D06 M18:SCUTLR2008G10 M19:SCCCLR2003H08 M20:SCSFLR2009B10 M21:SCCCLR2004C01 M22:SCQGLR2010C11 M23:SCCCLR2004E11 M24:SCAGLR2011A03 N01:SCAGLR2011E12 N02:SCAGLR2018C03 N03:SCVPLR2012B09 N04:SCAGLR2018H12 N05:SCVPLR2012E05 N06:SCVPLR2019D07 N07:SCVPLR2012H09 N08:SCJLLR2020A07 N09:SCJLLR2013D02 N10:SCJLLR2020G02 N11:SCJLLR2013H08 N12:SCRFLR2021D11 N13:SCACLR2014G02 N14:SCRFLR2021H12 N15:SCUTLR2015D07 N16:SCACLR2022D07 N17:SCSFLR2016B06 N18:SCUTLR2023A08 N19:SCSFLR2016E01 N20:SCUTLR2023F06 N21:SCQGLR2017A02 N22:SCSFLR2024B05 N23:SCQGLR2017D06 N24:SCSFLR2024H12 O01:SCCCLR1C07E06 O02:SCVPLR2005E11 O03:SCCCLR1C09C11 O04:SCJLLR2006A07 O05:SCCCLR1C10E08
O06:SCJLLR2006C12 O07:SCCCLR2001C02 O08:SCJLLR2006G12 O09:SCCCLR2001G10 O10:SCACLR2007B06 O11:SCCCLR2002B01 O12:SCACLR2007E03 O13:SCCCLR2002E09 O14:SCUTLR2008A11 O15:SCCCLR2002H08 O16:SCUTLR2008E02 O17:SCCCLR2003D08 O18:SCUTLR2008H01 O19:SCCCLR2003H12 O20:SCSFLR2009D05 O21:SCCCLR2004C02 O22:SCQGLR2010D05 O23:SCCCLR2004G03 O24:SCAGLR2011A11 P01:SCAGLR2011F11 P02:SCAGLR2018C08 P03:SCVPLR2012C01 P04:SCVPLR2019A01 P05:SCVPLR2012E06 P06:SCVPLR2019D12 P07:SCJLLR2013A03 P08:SCJLLR2020A10 P09:SCJLLR2013D11 P10:SCRFLR2021A04 P11:SCACLR2014C11 P12:SCRFLR2021E03 P13:SCACLR2014G05 P14:SCACLR2022A06 P15:SCUTLR2015E02 P16:SCACLR2022F04 P17:SCSFLR2016B07 P18:SCUTLR2023B01 P19:SCSFLR2016E06 P20:SCUTLR2023G06 P21:SCQGLR2017A12 P22:SCSFLR2024C04 P23:SCQGLR2017D07 P24:SCQGLR2025A06 
ANEXO E - PLACA SCUG 068

A01:SCQGLR2025A08 A02:SCSFLR2031H01 A03:SCQGLR2025E03 A04:SCQGLR2032F01 A05:SCQGLR2025H11 A06:SCAGLR2033B01 A07:SCAGLR2026F12 A08:SCAGLR2033D06 A09:SCVPLR2027A03 A10:SCAGLR2033H10 A11:SCVPLR2027D12 A12:SCRFLR2034E06 A13:SCJLLR2028A03 A14:SCJFLR2035E01 A15:SCJLLR2028F07 A16:SCJFLR2035H01 A17:SCACLR2029B07 A18:SCJFLR2036C09 A19:SCACLR2029H02 A20:SCJFLR2036G10 A21:SCUTLR2030E01 A22:SCRFLR2037C03 A23:SCSFLR2031A12 A24:SCRFLR2037H03 B01:SCRFLR2038C11 B02:SCSGLV1005C02 B03:SCCCLR2C01A12 B04:SCSGLV1006A03 B05:SCCCLR2C02A01 B06:SCSGLV1006H02 B07:SCCCLR2C02C02 B08:SCSGLV1007D10 B09:SCCCLR2C02F08 B10:SCSGLV1007G07 B11:SCCCLR2C03D04 B12:SCSGLV1008C05 B13:SCCCLV1001A06 B14:SCSGLV1008H07 B15:SCCCLV1001E05 B16:SCSGLV1009C06 B17:SCCCLV1002A11
B18:SCSGLV1009F02 B19:SCCCLV1003C07 B20:SCSGLV1010C07 B21:SCCCLV1003H08 B22:SCSGLV1011A08 B23:SCSGLV1004D10 B24:SCSGLV1011H01 C01:SCQGLR2025A09 C02:SCSFLR2031H06 C03:SCQGLR2025E04 C04:SCQGLR2032G02 C05:SCAGLR2026A09 C06:SCAGLR2033B05 C07:SCAGLR2026G01 C08:SCAGLR2033D08 C09:SCVPLR2027A07 C10:SCRFLR2034A02 C11:SCVPLR2027E06 C12:SCRFLR2034E07 C13:SCJLLR2028B06 C14:SCJFLR2035E02 C15:SCJLLR2028F08 C16:SCJFLR2035H04 C17:SCACLR2029C03 C18:SCJFLR2036D05 C19:SCACLR2029H09 C20:SCJFLR2036G11 C21:SCUTLR2030E04 C22:SCRFLR2037D02 C23:SCSFLR2031C04 C24:SCRFLR2037H06 D01:SCRFLR2038D04 D02:SCSGLV1005C06 D03:SCCCLR2C01B08 D04:SCSGLV1006A10 D05:SCCCLR2C02A02 D06:SCSGLV1006H09 D07:SCCCLR2C02C09 D08:SCSGLV1007D12 D09:SCCCLR2C02F09 D10:SCSGLV1007G11
D11:SCCCLR2C03D06 D12:SCSGLV1008C08 D13:SCCCLV1001B03 D14:SCSGLV1008H12 D15:SCCCLV1001E06 D16:SCSGLV1009C09 D17:SCCCLV1002C11 D18:SCSGLV1009F03 D19:SCCCLV1003D07 D20:SCSGLV1010D08 D21:SCCCLV1003H10 D22:SCSGLV1011A11 D23:SCSGLV1004E07 D24:SCSGLV1011H06 E01:SCQGLR2025A10 E02:SCQGLR2032B05 E03:SCQGLR2025E05 E04:SCQGLR2032G06 E05:SCAGLR2026B01 E06:SCAGLR2033C02 E07:SCAGLR2026G02 E08:SCAGLR2033D09 E09:SCVPLR2027A10 E10:SCRFLR2034A07 E11:SCVPLR2027F01 E12:SCRFLR2034H12 E13:SCJLLR2028B07 E14:SCJFLR2035E10 E15:SCJLLR2028G05 E16:SCJFLR2036A02 E17:SCACLR2029D02 E18:SCJFLR2036D10 E19:SCUTLR2030A04 E20:SCJFLR2036H06 E21:SCUTLR2030E07 E22:SCRFLR2037E07 E23:SCSFLR2031E04 E24:SCRFLR2037H11 F01:SCRFLR2038D07 F02:SCSGLV1005C07 F03:SCCCLR2C01B10 
F04:SCSGLV1006B06 F05:SCCCLR2C02A05 F06:SCSGLV1007A04 F07:SCCCLR2C02D02 F08:SCSGLV1007E05 F09:SCCCLR2C02G10 F10:SCSGLV1007G12 F11:SCCCLR2C03E02 F12:SCSGLV1008E10 F13:SCCCLV1001C03 F14:SCSGLV1009A11 F15:SCCCLV1001F07 F16:SCSGLV1009C11 F17:SCCCLV1002D06 F18:SCSGLV1009F07 F19:SCCCLV1003E06 F20:SCSGLV1010D10 F21:SCSGLV1004A02 F22:SCSGLV1011C06 F23:SCSGLV1004E08 F24:SCSGLV1011H11 G01:SCQGLR2025C06 G02:SCQGLR2032B10 G03:SCQGLR2025E08 G04:SCQGLR2032G07 G05:SCAGLR2026B05 G06:SCAGLR2033C06 G07:SCAGLR2026G05 G08:SCAGLR2033E09 G09:SCVPLR2027B10 G10:SCRFLR2034B04 G11:SCVPLR2027F07 G12:SCJFLR2035A01 G13:SCJLLR2028B10 G14:SCJFLR2035E12 G15:SCJLLR2028G06 G16:SCJFLR2036A04 G17:SCACLR2029D05 G18:SCJFLR2036F02 G19:SCUTLR2030A07 G20:SCJFLR2036H07 G21:SCUTLR2030H01 G22:SCRFLR2037E08 G23:SCSFLR2031E06 G24:SCRFLR2038A02
H01:SCRFLR2038F06 H02:SCSGLV1005D02 H03:SCCCLR2C01C08 H04:SCSGLV1006C01 H05:SCCCLR2C02A12 H06:SCSGLV1007A08 H07:SCCCLR2C02D04 H08:SCSGLV1007E06 H09:SCCCLR2C02H05 H10:SCSGLV1007H04 H11:SCCCLR2C03F07 H12:SCSGLV1008F02 H13:SCCCLV1001C05 H14:SCSGLV1009B01 H15:SCCCLV1001G08 H16:SCSGLV1009D03 H17:SCCCLV1002G12 H18:SCSGLV1009G06 H19:SCCCLV1003E11 H20:SCSGLV1010E01 H21:SCSGLV1004A04 H22:SCSGLV1011C09 H23:SCSGLV1004F11 H24:SCSGLV1012A03 101:SCQGLR2025D06 102:SCQGLR2032D03 103:SCQGLR2025F06 104:SCQGLR2032G12 105:SCAGLR2026C07 106:SCAGLR2033C09 107:SCAGLR2026G07 108:SCAGLR2033G01 109:SCVPLR2027C08 110:SCRFLR2034B05 111:SCVPLR2027F08 112:SCJFLR2035A07 113:SCJLLR2028B11 114:SCJFLR2035F03 115:SCJLLR2028G09 116:SCJFLR2036B10 I17:SCACLR2029E02 I18:SCJFLR2036F07 119:SCUTLR2030B11 120:SCRFLR2037A04 121:SCUTLR2030H09
122:SCRFLR2037E12 123:SCSFLR2031E10 124:SCRFLR2038A11 J01:SCRFLR2038F10 J02:SCSGLV1005E05 J03:SCCCLR2C01C11 J04:SCSGLV1006C10 J05:SCCCLR2C02B04 J06:SCSGLV1007B04 J07:SCCCLR2C02D06 J08:SCSGLV1007F06 J09:SCCCLR2C03A08 J10:SCSGLV1008A09 J11:SCCCLR2C03F08 J12:SCSGLV1008F06 J13:SCCCLV1001C09 J14:SCSGLV1009B02 J15:SCCCLV1001G09 J16:SCSGLV1009D06 J17:SCCCLV1002H05 J18:SCSGLV1009G12 J19:SCCCLV1003F02 J20:SCSGLV1010F06 J21:SCSGLV1004A12 J22:SCSGLV1011D02 J23:SCSGLV1004G01 J24:SCSGLV1012A09 K01:SCQGLR2025D10 K02:SCQGLR2032D06 K03:SCQGLR2025G12 K04:SCQGLR2032H01 K05:SCAGLR2026C10 K06:SCAGLR2033C10 K07:SCAGLR2026H05 K08:SCAGLR2033G09 K09:SCVPLR2027C11 K10:SCRFLR2034B07 K11:SCVPLR2027G10 K12:SCJFLR2035C02 K13:SCJLLR2028C05 K14:SCJFLR2035F04 K15:SCJLLR2028G10 K16:SCJFLR2036B11 K17:SCACLR2029E09 K18:SCJFLR2036F11 
K19:SCUTLR2030C07 K20:SCRFLR2037B02 K21:SCSFLR2031A01 K22:SCRFLR2037F01 K23:SCSFLR2031E12 K24:SCRFLR2038B08 L01:SCRFLR2038H11 L02:SCSGLV1005E06 L03:SCCCLR2C01E07 L04:SCSGLV1006E06 L05:SCCCLR2C02B08 L06:SCSGLV1007C06 L07:SCCCLR2C02E04 L08:SCSGLV1007F11 L09:SCCCLR2C03B02 L10:SCSGLV1008B03 L11:SCCCLR2C03G04 L12:SCSGLV1008F12 L13:SCCCLV1001D01 L14:SCSGLV1009B07 L15:SCCCLV1001H05 L16:SCSGLV1009D11 L17:SCCCLV1003A01 L18:SCSGLV1009H12 L19:SCCCLV1003G02 L20:SCSGLV1010F12 L21:SCSGLV1004B01 L22:SCSGLV1011E09 L23:SCSGLV1004G02 L24:SCSGLV1012A10 M01:SCQGLR2025E01 M02:SCQGLR2032D11 M03:SCQGLR2025H08 M04:SCQGLR2032H12 M05:SCAGLR2026E05 M06:SCAGLR2033C11 M07:SCAGLR2026H11 M08:SCAGLR2033G11 M09:SCVPLR2027D03 M10:SCRFLR2034B11 M11:SCVPLR2027H01 M12:SCJFLR2035D10
M13:SCJLLR2028D03 M14:SCJFLR2035F06 M15:SCJLLR2028H08 M16:SCJFLR2036C01 M17:SCACLR2029F05 M18:SCJFLR2036G04 M19:SCUTLR2030C12 M20:SCRFLR2037B12 M21:SCSFLR2031A07 M22:SCRFLR2037F09 M23:SCSFLR2031F05 M24:SCRFLR2038B09 N01:SCRFLR2038H12 N02:SCSGLV1005G05 N03:SCCCLR2C01E09 N04:SCSGLV1006E08 N05:SCCCLR2C02B09 N06:SCSGLV1007C08 N07:SCCCLR2C02F01 N08:SCSGLV1007G01 N09:SCCCLR2C03D02 N10:SCSGLV1008B08 N11:SCCCLV1001A01 N12:SCSGLV1008G05 N13:SCCCLV1001D06 N14:SCSGLV1009B12 N15:SCCCLV1001H06 N16:SCSGLV1009E06 N17:SCCCLV1003A11 N18:SCSGLV1010A03 N19:SCCCLV1003G03 N20:SCSGLV1010G02 N21:SCSGLV1004B06 N22:SCSGLV1011F05 N23:SCSGLV1004G06 N24:SCSGLV1012B01 O01:SCQGLR2025E02 O02:SCQGLR2032E04 O03:SCQGLR2025H10 O04:SCAGLR2033A08 O05:SCAGLR2026F05 O06:SCAGLR2033D01
O07:SCAGLR2026H12 O08:SCAGLR2033H01 O09:SCVPLR2027D05 O10:SCRFLR2034D04 O11:SCVPLR2027H12 O12:SCJFLR2035D11 O13:SCJLLR2028E05 O14:SCJFLR2035G11 O15:SCACLR2029A05 O16:SCJFLR2036C03 O17:SCACLR2029H01 O18:SCJFLR2036G07 O19:SCUTLR2030D12 O20:SCRFLR2037C01 O21:SCSFLR2031A11 O22:SCRFLR2037G02 O23:SCSFLR2031G06 O24:SCRFLR2038C06 P01:SCCCLR2C01A03 P02:SCSGLV1005H10 P03:SCCCLR2C01G05 P04:SCSGLV1006F11 P05:SCCCLR2C02B11 P06:SCSGLV1007D05 P07:SCCCLR2C02F06 P08:SCSGLV1007G03 P09:SCCCLR2C03D03 P10:SCSGLV1008C01 P11:SCCCLV1001A04 P12:SCSGLV1008H05 P13:SCCCLV1001D08 P14:SCSGLV1009C03 P15:SCCCLV1002A09 P16:SCSGLV1009E12 P17:SCCCLV1003B07 P18:SCSGLV1010B03 P19:SCCCLV1003H07 P20:SCSGLV1011A05 P21:SCSGLV1004C01 P22:SCSGLV1011G01 P23:SCSGLV1005A11 P24:SCSGLV1012B03 
ANEXO F - PLACA SCUG 107

A01:SCQSST1039E03

A02:SCRFST1044G04 A03:SCQSST1039H02 A04:SCRFST1045C11 A05:SCQSST1040D08 A06:SCRFST1045E10 A07:SCQSST1040G01 A08:SCRFST1045H02 A09:SCRFST1041C01 A10:SCRFST1046C07 A11:SCRFST1041E05 A12:SCJFST1047A03 A13:SCRFST1042A08 A14:SCJFST1047C11 A15:SCRFST1042D06 A16:SCJFST1047E02 A17:SCRFST1043A02 A18:SCJFST1047H11 A19:SCRFST1043D09 A20:SCJFST1048E06 A21:SCRFST1044A09 A22:SCJFST1048H01 A23:SCRFST1044D02 A24:SCMCST1049A08 B01:SCMCST1049C10 B02:SCMCST1053D07 B03:SCMCST1049F03 B04:SCMCST1053F02 B05:SCMCST1049H09 B06:SCMCST1054B02 B07:SCMCST1050D10 B08:SCMCST1054E10 B09:SCMCST1050F09 B10:SCMCST1054G12 B11:SCMCST1051A07 B12:SCMCST1055C08 B13:SCMCST1051C10 B14:SCMCST1055F12 B15:SCMCST1051F09 B16:SCMCST1056C10 B17:SCMCST1052B05
B18:SCMCST1056F04 B19:SCMCST1052E03 B20:SCMCST1056G10 B21:SCMCST1052H11 B22:SCMCST1057A10 B23:SCMCST1053B01 B24:SCMCST1057E01 C01:SCQSST1039E06 C02:SCRFST1044G05 C03:SCQSST1039H10 C04:SCRFST1045C12 C05:SCQSST1040D11 C06:SCRFST1045E11 C07:SCQSST1040G09 C08:SCRFST1045H03 C09:SCRFST1041C03 C10:SCRFST1046C10 C11:SCRFST1041E06 C12:SCJFST1047A05 C13:SCRFST1042A10 C14:SCJFST1047C12 C15:SCRFST1042D08 C16:SCJFST1047E11 C17:SCRFST1043A03 C18:SCJFST1047H12 C19:SCRFST1043E12 C20:SCJFST1048F08 C21:SCRFST1044B04 C22:SCJFST1048H03 C23:SCRFST1044D08 C24:SCMCST1049B01 D01:SCMCST1049D01 D02:SCMCST1053D08 D03:SCMCST1049F04 D04:SCMCST1053F08 D05:SCMCST1050A07 D06:SCMCST1054B03 D07:SCMCST1050E02 D08:SCMCST1054E11 D09:SCMCST1050F10 D10:SCMCST1054H07
D11:SCMCST1051A10 D12:SCMCST1055C09 D13:SCMCST1051C11 D14:SCMCST1055G02 D15:SCMCST1051F11 D16:SCMCST1056C12 D17:SCMCST1052B09 D18:SCMCST1056F05 D19:SCMCST1052E09 D20:SCMCST1056G12 D21:SCMCST1052H12 D22:SCMCST1057B02 D23:SCMCST1053B06 D24:SCMCST1057E03 E01:SCQSST1039E12 E02:SCRFST1044H04 E03:SCQSST1040A12 E04:SCRFST1045D01 E05:SCQSST1040E01 E06:SCRFST1045F01 E07:SCQSST1040H07 E08:SCRFST1045H04 E09:SCRFST1041C05 E10:SCRFST1046E04 E11:SCRFST1041F03 E12:SCJFST1047A10 E13:SCRFST1042B02 E14:SCJFST1047D01 E15:SCRFST1042D12 E16:SCJFST1047F10 E17:SCRFST1043A08 E18:SCJFST1048A01 E19:SCRFST1043F06 E20:SCJFST1048F09 E21:SCRFST1044B09 E22:SCJFST1048H04 E23:SCRFST1044D09 E24:SCMCST1049B10 F01:SCMCST1049D04 F02:SCMCST1053D12 F03:SCMCST1049F05 
F04:SCMCST1053F11 F05:SCMCST1050B05 F06:SCMCST1054B09 F07:SCMCST1050E10 F08:SCMCST1054F01 F09:SCMCST1050G12 F10:SCMCST1055A06 F11:SCMCST1051A11 F12:SCMCST1055D01 F13:SCMCST1051D02 F14:SCMCST1055G10 F15:SCMCST1052A03 F16:SCMCST1056D06 F17:SCMCST1052C03 F18:SCMCST1056F08 F19:SCMCST1052E12 F20:SCMCST1056H01 F21:SCMCST1053A03 F22:SCMCST1057B06 F23:SCMCST1053B08 F24:SCMCST1057E09 G01:SCQSST1039F02 G02:SCRFST1044H06 G03:SCQSST1040B01 G04:SCRFST1045D05 G05:SCQSST1040E04 G06:SCRFST1045F09 G07:SCQSST1040H08 G08:SCRFST1045H09 G09:SCRFST1041D02 G10:SCRFST1046F05 G11:SCRFST1041G03 G12:SCJFST1047A11 G13:SCRFST1042B03 G14:SCJFST1047D04 G15:SCRFST1042E04 G16:SCJFST1047F11 G17:SCRFST1043C03 G18:SCJFST1048A02 G19:SCRFST1043G03 G20:SCJFST1048F11 G21:SCRFST1044C06 G22:SCJFST1048H07 G23:SCRFST1044E05 G24:SCMCST1049B11
H01:SCMCST1049D09 H02:SCMCST1053E02 H03:SCMCST1049F08 H04:SCMCST1053G08 H05:SCMCST1050B09 H06:SCMCST1054B12 H07:SCMCST1050E11 H08:SCMCST1054F03 H09:SCMCST1050H06 H10:SCMCST1055B01 H11:SCMCST1051B03 H12:SCMCST1055D09 H13:SCMCST1051D06 H14:SCMCST1055H08 H15:SCMCST1052A04 H16:SCMCST1056D08 H17:SCMCST1052C09 H18:SCMCST1056F10 H19:SCMCST1052F10 H20:SCMCST1056H07 H21:SCMCST1053A04 H22:SCMCST1057B07 H23:SCMCST1053C05 H24:SCMCST1057F01 101:SCQSST1039F05 102:SCRFST1044H07 103:SCQSST1040B12 104:SCRFST1045D07 105:SCQSST1040E08 106:SCRFST1045F11 107:SCQSST1040H10 108:SCRFST1045H12 109:SCRFST1041D04 110:SCRFST1046G02 111:SCRFST1041G07 I12:SCJFST1047B01 I13:SCRFST1042B04 114:SCJFST1047D07 I15:SCRFST1042E09 116:SCJFST1047G02 I17:SCRFST1043C06 118:SCJFST1048A10 I19:SCRFST1043G04 120:SCJFST1048G04 121:SCRFST1044C08
122:SCJFST1048H08 I23:SCRFST1044F01 124:SCMCST1049B12 J01:SCMCST1049D12 J02:SCMCST1053E03 J03:SCMCST1049F12 J04:SCMCST1053H04 J05:SCMCST1050C05 J06:SCMCST1054C11 J07:SCMCST1050F01 J08:SCMCST1054F06 J09:SCMCST1050H07 J10:SCMCST1055B08 J11:SCMCST1051B05 J12:SCMCST1055D10 J13:SCMCST1051D09 J14:SCMCST1055H12 J15:SCMCST1052A06 J16:SCMCST1056E03 J17:SCMCST1052C10 J18:SCMCST1056G02 J19:SCMCST1052G03 J20:SCMCST1057A04 J21:SCMCST1053A05 J22:SCMCST1057C02 J23:SCMCST1053C06 J24:SCMCST1057F02 K01:SCQSST1039F10 K02:SCRFST1045A11 K03:SCQSST1040C01 K04:SCRFST1045D11 K05:SCQSST1040F01 K06:SCRFST1045G05 K07:SCRFST1041A02 K08:SCRFST1046A04 K09:SCRFST1041D07 K10:SCRFST1046H05 K11:SCRFST1041G08 K12:SCJFST1047B11 K13:SCRFST1042B06 K14:SCJFST1047D08 K15:SCRFST1042G03 K16:SCJFST1047G04 K17:SCRFST1043C11 K18:SCJFST1048C09 
K19:SCRFST1043H06 K20:SCJFST1048G05 K21:SCRFST1044C10 K22:SCJFST1048H11 K23:SCRFST1044F03 K24:SCMCST1049C05 L01:SCMCST1049E02 L02:SCMCST1053E06 L03:SCMCST1049G04 L04:SCMCST1053H12 L05:SCMCST1050C11 L06:SCMCST1054D04 L07:SCMCST1050F02 L08:SCMCST1054F10 L09:SCMCST1050H09 L10:SCMCST1055B09 L11:SCMCST1051B07 L12:SCMCST1055F01 L13:SCMCST1051E01 L14:SCMCST1056A11 L15:SCMCST1052A09 L16:SCMCST1056E04 L17:SCMCST1052D06 L18:SCMCST1056G07 L19:SCMCST1052G07 L20:SCMCST1057A05 L21:SCMCST1053A06 L22:SCMCST1057C10 L23:SCMCST1053C07 L24:SCMCST1057F06 M01:SCQSST1039G08 M02:SCRFST1045B03 M03:SCQSST1040C10 M04:SCRFST1045E05 M05:SCQSST1040F02 M06:SCRFST1045G09 M07:SCRFST1041A09 M08:SCRFST1046B03 M09:SCRFST1041D10 M10:SCRFST1046H06 M11:SCRFST1041H05 M12:SCJFST1047C03
M13:SCRFST1042C02 M14:SCJFST1047D10 M15:SCRFST1042G07 M16:SCJFST1047G12 M17:SCRFST1043D03 M18:SCJFST1048D12 M19:SCRFST1043H09 M20:SCJFST1048G07 M21:SCRFST1044C11 M22:SCMCST1049A02 M23:SCRFST1044F06 M24:SCMCST1049C07 N01:SCMCST1049E05 N02:SCMCST1053E10 N03:SCMCST1049G08 N04:SCMCST1054A05 N05:SCMCST1050C12 N06:SCMCST1054E03 N07:SCMCST1050F05 N08:SCMCST1054G04 N09:SCMCST1050H10 N10:SCMCST1055B11 N11:SCMCST1051B11 N12:SCMCST1055F03 N13:SCMCST1051E05 N14:SCMCST1056B05 N15:SCMCST1052B02 N16:SCMCST1056E07 N17:SCMCST1052D08 N18:SCMCST1056G08 N19:SCMCST1052G11 N20:SCMCST1057A06 N21:SCMCST1053A11 N22:SCMCST1057D03 N23:SCMCST1053D01 N24:SCMCST1057F12 O01:SCQSST1039G09 O02:SCRFST1045C02 O03:SCQSST1040D02 O04:SCRFST1045E09 O05:SCQSST1040F12 O06:SCRFST1045G10
O07:SCRFST1041B06 O08:SCRFST1046B08 O09:SCRFST1041E03 O10:SCRFST1046H11 O11:SCRFST1042A04 O12:SCJFST1047C06 O13:SCRFST1042C05 O14:SCJFST1047D11 O15:SCRFST1042H08 O16:SCJFST1047H05 O17:SCRFST1043D07 O18:SCJFST1048E05 O19:SCRFST1044A04 O20:SCJFST1048G08 O21:SCRFST1044C12 O22:SCMCST1049A07 O23:SCRFST1044F07 O24:SCMCST1049C08 P01:SCMCST1049F01 P02:SCMCST1053E11 P03:SCMCST1049H02 P04:SCMCST1054A06 P05:SCMCST1050D04 P06:SCMCST1054E04 P07:SCMCST1050F06 P08:SCMCST1054G09 P09:SCMCST1051A04 P10:SCMCST1055C06 P11:SCMCST1051C04 P12:SCMCST1055F08 P13:SCMCST1051E08 P14:SCMCST1056C05 P15:SCMCST1052B04 P16:SCMCST1056F02 P17:SCMCST1052E02 P18:SCMCST1056G09 P19:SCMCST1052H04 P20:SCMCST1057A08 P21:SCMCST1053A12 P22:SCMCST1057D06 P23:SCMCST1053D03 P24:SCMCST1057G01 
A01:SCMCST1057G05 A02:SCVPST1062B10 A03:SCMCST1058A05 A04:SCVPST1062D01 A05:SCMCST1058C02 A06:SCVPST1062G02 A07:SCMCST1058G06 A08:SCVPST1063A12 A09:SCVPST1059A10 A10:SCVPST1063E01 A11:SCVPST1059F09 A12:SCVPST1063F10 A13:SCVPST1060B03 A14:SCSFST1064B02 A15:SCVPST1060D07 A16:SCSFST1064G02 A17:SCVPST1060G07 A18:SCSFST1065B06 A19:SCVPST1061C06 A20:SCSFST1065E01 A21:SCVPST1061E10 A22:SCSFST1066B06 A23:SCVPST1061G12 A24:SCSFST1066F08 B01:SCSFST1066H11 B02:SCSGST1071E07 B03:SCSFST1067E07 B04:SCSGST1071H05 B05:SCSFST1067H09 B06:SCSGST1072C04 B07:SCSGST1068B09 B08:SCSGST1072F06 B09:SCSGST1068D05 B10:SCCCST1C01B03 B11:SCSGST1068F10 B12:SCCCST1C02D04 B13:SCSGST1069B02 B14:SCCCST1C03B10 B15:SCSGST1069E06 B16:SCCCST1C04A12 B17:SCSGST1069H03
B18:SCCCST1C05B12 B19:SCSGST1070C10 B20:SCCCST1C06B03 B21:SCSGST1070G05 B22:SCCCST1C06E09 B23:SCSGST1071B11 B24:SCCCST2001E08 C01:SCMCST1057G07 C02:SCVPST1062C02 C03:SCMCST1058A06 C04:SCVPST1062D07 C05:SCMCST1058C12 C06:SCVPST1062G03 C07:SCMCST1058H03 C08:SCVPST1063B02 C09:SCVPST1059B02 C10:SCVPST1063E05 C11:SCVPST1059G01 C12:SCVPST1063G10 C13:SCVPST1060B04 C14:SCSFST1064B07 C15:SCVPST1060D09 C16:SCSFST1064G06 C17:SCVPST1060G09 C18:SCSFST1065B10 C19:SCVPST1061C09 C20:SCSFST1065E04 C21:SCVPST1061F03 C22:SCSFST1066C11 C23:SCVPST1061H02 C24:SCSFST1066F12 D01:SCSFST1067A09 D02:SCSGST1071E08 D03:SCSFST1067E08 D04:SCSGST1071H06 D05:SCSGST1068A01 D06:SCSGST1072C10 D07:SCSGST1068B10 D08:SCSGST1072F08 D09:SCSGST1068D07 D10:SCCCST1C01B10
D11:SCSGST1068F12 D12:SCCCST1C02D08 D13:SCSGST1069B05 D14:SCCCST1C03D04 D15:SCSGST1069E11 D16:SCCCST1C04B04 D17:SCSGST1069H08 D18:SCCCST1C05C01 D19:SCSGST1070C11 D20:SCCCST1C06B08 D21:SCSGST1070G11 D22:SCCCST1C06F10 D23:SCSGST1071B12 D24:SCCCST2001G08 E01:SCMCST1057G09 E02:SCVPST1062C04 E03:SCMCST1058A07 E04:SCVPST1062E02 E05:SCMCST1058D07 E06:SCVPST1062G06 E07:SCMCST1058H08 E08:SCVPST1063B11 E09:SCVPST1059B08 E10:SCVPST1063E06 E11:SCVPST1059G11 E12:SCVPST1063G11 E13:SCVPST1060B06 E14:SCSFST1064B08 E15:SCVPST1060D10 E16:SCSFST1064G07 E17:SCVPST1060G10 E18:SCSFST1065B11 E19:SCVPST1061D03 E20:SCSFST1065G05 E21:SCVPST1061F04 E22:SCSFST1066D04 E23:SCVPST1061H08 E24:SCSFST1066G01 F01:SCSFST1067B01 F02:SCSGST1071F01 F03:SCSFST1067E10 
F04:SCSGST1072A01 F05:SCSGST1068A02 F06:SCSGST1072D04 F07:SCSGST1068C02 F08:SCSGST1072F10 F09:SCSGST1068E04 F10:SCCCST1C01G10 F11:SCSGST1068G01 F12:SCCCST1C02D11 F13:SCSGST1069C02 F14:SCCCST1C03E09 F15:SCSGST1069F03 F16:SCCCST1C04D02 F17:SCSGST1069H09 F18:SCCCST1C05C08 F19:SCSGST1070D10 F20:SCCCST1C06C01 F21:SCSGST1070G12 F22:SCCCST1C06H04 F23:SCSGST1071C01 F24:SCCCST2001H01 G01:SCMCST1057G10 G02:SCVPST1062C06 G03:SCMCST1058B02 G04:SCVPST1062E07 G05:SCMCST1058D11 G06:SCVPST1062G12 G07:SCMCST1058H11 G08:SCVPST1063C04 G09:SCVPST1059D04 G10:SCVPST1063E08 G11:SCVPST1059H07 G12:SCVPST1063G12 G13:SCVPST1060B10 G14:SCSFST1064C03 G15:SCVPST1060E08 G16:SCSFST1064H01 G17:SCVPST1060H02 G18:SCSFST1065C03 G19:SCVPST1061D07 G20:SCSFST1065G11 G21:SCVPST1061F08 G22:SCSFST1066E03 G23:SCVPST1061H09 G24:SCSFST1066G03
H01:SCSFST1067B10 H02:SCSGST1071F03 H03:SCSFST1067F10 H04:SCSGST1072A04 H05:SCSGST1068A04 H06:SCSGST1072E02 H07:SCSGST1068C04 H08:SCSGST1072G05 H09:SCSGST1068E08 H10:SCCCST1C01H07 H11:SCSGST1068G03 H12:SCCCST1C02E11 H13:SCSGST1069C03 H14:SCCCST1C03F10 H15:SCSGST1069F05 H16:SCCCST1C04E01 H17:SCSGST1069H11 H18:SCCCST1C05F01 H19:SCSGST1070D11 H20:SCCCST1C06C04 H21:SCSGST1070H05 $\mathrm{H} 22$ :SCCCST1C06H10 H23:SCSGST1071C02 H24:SCCCST2002A02 101:SCMCST1057H03 102:SCVPST1062C07 103:SCMCST1058B08 104:SCVPST1062F02 105:SCMCST1058E11 106:SCVPST1062H04 107:SCMCST1058H12 I08:SCVPST1063C05 109:SCVPST1059D05 I10:SCVPST1063E10 I11:SCVPST1059H08 I12:SCVPST1063H10 I13:SCVPST1060B12 I14:SCSFST1064C07 115:SCVPST1060E09 116:SCSFST1064H04 I17:SCVPST1060H12 I18:SCSFST1065C06 I19:SCVPST1061D09 120:SCSFST1065H03 121:SCVPST1061F10
122:SCSFST1066E05 123:SCVPST1062A07 124:SCSFST1066G08 J01:SCSFST1067B12 J02:SCSGST1071F05 J03:SCSFST1067F12 J04:SCSGST1072A05 J05:SCSGST1068A08 J06:SCSGST1072E03 J07:SCSGST1068C10 J08:SCSGST1072G11 J09:SCSGST1068E09 J10:SCCCST1C02A04 J11:SCSGST1068G05 J12:SCCCST1C02F10 J13:SCSGST1069C07 J14:SCCCST1C03G07 J15:SCSGST1069F12 J16:SCCCST1C04H05 J17:SCSGST1069H12 J18:SCCCST1C05H11 J19:SCSGST1070E06 J20:SCCCST1C06C07 J21:SCSGST1071A08 J22:SCCCST2001A07 J23:SCSGST1071C03 J24:SCCCST2002B07 K01:SCMCST1057H06 K02:SCVPST1062C09 K03:SCMCST1058B09 K04:SCVPST1062F03 K05:SCMCST1058G02 K06:SCVPST1062H11 K07:SCVPST1059A04 K08:SCVPST1063C06 K09:SCVPST1059E01 K10:SCVPST1063F01 K11:SCVPST1059H11 K12:SCSFST1064A06 K13:SCVPST1060C02 K14:SCSFST1064C10 K15:SCVPST1060F02 K16:SCSFST1064H11 K17:SCVPST1061A01 K18:SCSFST1065C07 
K19:SCVPST1061D11 K20:SCSFST1065H10 K21:SCVPST1061G03 K22:SCSFST1066E06 K23:SCVPST1062B01 K24:SCSFST1066G09 L01:SCSFST1067C06 L02:SCSGST1071G01 L03:SCSFST1067G06 L04:SCSGST1072A08 L05:SCSGST1068A11 L06:SCSGST1072E07 L07:SCSGST1068C11 L08:SCSGST1072H01 L09:SCSGST1068F02 L10:SCCCST1C02A10 L11:SCSGST1068H03 L12:SCCCST1C02H05 L13:SCSGST1069C11 L14:SCCCST1C03H05 L15:SCSGST1069G05 L16:SCCCST1C04H09 L17:SCSGST1070B04 L18:SCCCST1C06A01 L19:SCSGST1070E09 L20:SCCCST1C06C09 L21:SCSGST1071B01 L22:SCCCST2001B04 L23:SCSGST1071C04 L24:SCCCST2002E08 M01:SCMCST1057H08 M02:SCVPST1062C11 M03:SCMCST1058B10 M04:SCVPST1062F05 M05:SCMCST1058G04 M06:SCVPST1062H12 M07:SCVPST1059A06 M08:SCVPST1063C07 M09:SCVPST1059F03 M10:SCVPST1063F02 M11:SCVPST1060A10 M12:SCSFST1064A12
M13:SCVPST1060C06 M14:SCSFST1064D02 M15:SCVPST1060F07 M16:SCSFST1065A03 M17:SCVPST1061B09 M18:SCSFST1065C10 M19:SCVPST1061D12 M20:SCSFST1066A05 M21:SCVPST1061G05 M22:SCSFST1066E08 M23:SCVPST1062B04 M24:SCSFST1066G11 N01:SCSFST1067D04 N02:SCSGST1071G03 N03:SCSFST1067G11 N04:SCSGST1072B08 N05:SCSGST1068B01 N06:SCSGST1072F02 N07:SCSGST1068C12 N08:SCSGST1072H02 N09:SCSGST1068F05 N10:SCCCST1C02B11 N11:SCSGST1068H05 $\mathrm{N} 12: S C C C S T 1 C 02 \mathrm{H} 07$ N13:SCSGST1069D02 N14:SCCCST1C03H09 N15:SCSGST1069G11 N16:SCCCST1C05A01 N17:SCSGST1070B11 N18:SCCCST1C06A03 N19:SCSGST1070F10 N20:SCCCST1C06D01 N21:SCSGST1071B07 N22:SCCCST2001E01 N23:SCSGST1071C07 N24:SCCCST2002G10 O01:SCMCST1057H10 O02:SCVPST1062C12 O03:SCMCST1058C01 O04:SCVPST1062F10 O05:SCMCST1058G05 O06:SCVPST1063A10
O07:SCVPST1059A09 O08:SCVPST1063D12 O09:SCVPST1059F07 O10:SCVPST1063F09 011:SCVPST1060B02 O12:SCSFST1064B01 O13:SCVPST1060D02 O14:SCSFST1064D10 O15:SCVPST1060G05 O16:SCSFST1065B01 O17:SCVPST1061B10 O18:SCSFST1065D06 O19:SCVPST1061E07 O20:SCSFST1066A11 O21:SCVPST1061G07 O22:SCSFST1066E10 O23:SCVPST1062B08 O24:SCSFST1066H04 P01:SCSFST1067E03 P02:SCSGST1071G09 P03:SCSFST1067H05 P04:SCSGST1072C02 P05:SCSGST1068B05 P06:SCSGST1072F04 P07:SCSGST1068D04 P08:SCSGST1072H12 P09:SCSGST1068F09 P10:SCCCST1C02C06 P11:SCSGST1068H09 P12:SCCCST1C03B03 P13:SCSGST1069D04 P14:SCCCST1C04A10 P15:SCSGST1069H02 P16:SCCCST1C05B02 P17:SCSGST1070C08 P18:SCCCST1C06A07 P19:SCSGST1070G02 P20:SCCCST1C06D03 P21:SCSGST1071B09 P22:SCCCST2001E04 P23:SCSGST1071C08 P24:SCCCST2002G12 
ANEXO H - PLACA SCUG 109

A01:SCCCST2002H08 A02:SCSFST3074E02 A03:SCCCST2003F07 A04:SCSFST3075A09 A05:SCCCST2004G08 A06:SCSFST3076B12 A07:SCCCST3001D10 A08:SCSFST3077A10 A09:SCCCST3002C12 A10:SCSFST3077D09 A11:SCCCST3002G09 A12:SCSFST3078F06 A13:SCCCST3003H07 A14:SCSFST3079D01 A15:SCCCST3005A10 A16:SCSFST3080G06 A17:SCCCST3005H10 A18:SCSFST3081F11 A19:SCCCST3006G06 A20:SCSFST3082D06 A21:SCSFST3073A12 A22:SCCCST3083A07 A23:SCSFST3073H03 A24:SCCCST3083G12 B01:SCUTST3084G03 B02:SCSBST3094B10 B03:SCUTST3085F01 B04:SCSBST3095A07 B05:SCUTST3086E06 B06:SCSBST3095G06 B07:SCUTST3087E08 B08:SCSBST3096D09 B09:SCUTST3088C02 B10:SCSBST3098B01 B11:SCUTST3089A09 B12:SCSBST3098H04 B13:SCUTST3089F09 B14:SCSBST3099H05 B15:SCUTST3090H08 B16:SCSBST3100C09 B17:SCUTST3091F02
B18:SCSBST3101C10 B19:SCUTST3092C08 B20:SCSBST3102B03 B21:SCUTST3092G12 B22:SCSBST3102G10 B23:SCSBST3093D08 B24:SCBGST3103E12 C01:SCCCST2003B09 C02:SCSFST3074E12 C03:SCCCST2004B02 C04:SCSFST3075C04 C05:SCCCST2004H05 C06:SCSFST3076C11 C07:SCCCST3001E01 C08:SCSFST3077B02 C09:SCCCST3002D02 C10:SCSFST3077F12 C11:SCCCST3002G10 C12:SCSFST3078G01 C13:SCCCST3004A05 C14:SCSFST3079E04 C15:SCCCST3005B02 C16:SCSFST3080H07 C17:SCCCST3006B02 C18:SCSFST3081H01 C19:SCCCST3006G10 C20:SCSFST3082E05 C21:SCSFST3073C11 C22:SCCCST3083A12 C23:SCSFST3073H10 C24:SCCCST3083H05 D01:SCUTST3084G11 D02:SCSBST3094C09 D03:SCUTST3085G03 D04:SCSBST3095B06 D05:SCUTST3086E08 D06:SCSBST3095G12 D07:SCUTST3087E10 D08:SCSBST3096E03 D09:SCUTST3088C12 D10:SCSBST3098C11
D11:SCUTST3089A12 D12:SCSBST3099B04 D13:SCUTST3089H10 D14:SCSBST3099H08 D15:SCUTST3091A01 D16:SCSBST3100C11 D17:SCUTST3091F07 D18:SCSBST3101D08 D19:SCUTST3092D01 D20:SCSBST3102B07 D21:SCUTST3092H05 D22:SCBGST3103A02 D23:SCSBST3093E04 D24:SCBGST3103F08 E01:SCCCST2003C02 E02:SCSFST3074F02 E03:SCCCST2004C04 E04:SCSFST3075D07 E05:SCCCST3001B03 E06:SCSFST3076D07 E07:SCCCST3001F01 E08:SCSFST3077B12 E09:SCCCST3002D06 E10:SCSFST3077G07 E11:SCCCST3002H12 E12:SCSFST3078H05 E13:SCCCST3004A06 E14:SCSFST3079E08 E15:SCCCST3005C01 E16:SCSFST3080H09 E17:SCCCST3006B09 E18:SCSFST3081H12 E19:SCCCST3006H06 E20:SCSFST3082E09 E21:SCSFST3073C12 E22:SCCCST3083D10 E23:SCSFST3073H11 E24:SCUTST3084A01 F01:SCUTST3085B04 F02:SCSBST3094D09 F03:SCUTST3086A08 
F04:SCSBST3095B09

F05:SCUTST3086E10

F06:SCSBST3095H03

F07:SCUTST3087F09

F08:SCSBST3096H07

F09:SCUTST3088D09

F10:SCSBST3098E03

F11:SCUTST3089B07

F12:SCSBST3099B12

F13:SCUTST3090A02

F14:SCSBST3100A01

F15:SCUTST3091B04

F16:SCSBST3100D07

F17:SCUTST3091G03

F18:SCSBST3101E01

F19:SCUTST3092D07

F20:SCSBST3102C02

F21:SCSBST3093A05

F22:SCBGST3103A03

F23:SCSBST3093E07

F24:SCBGST3103G10

G01:SCCCST2003D03

G02:SCSFST3074F09

G03:SCCCST2004D06

G04:SCSFST3075D10

G05:SCCCST3001B05

G06:SCSFST3076D08

G07:SCCCST3001F05

G08:SCSFST3077C02

G09:SCCCST3002E02

G10:SCSFST3077H03

G11:SCCCST3003D12

G12:SCSFST3079A05

G13:SCCCST3004B04

G14:SCSFST3079E11

G15:SCCCST3005C02

G16:SCSFST3081A09

G17:SCCCST3006C02

G18:SCSFST3082A04

G19:SCCCST3006H09

G20:SCSFST3082E10

G21:SCSFST3073D09

G22:SCCCST3083E03

G23:SCSFST3074C01

G24:SCUTST3084C11
H01:SCUTST3085B08 H02:SCSBST3094E04 H03:SCUTST3086B02 H04:SCSBST3095C01 H05:SCUTST3086E12 H06:SCSBST3095H05 H07:SCUTST3087G01 H08:SCSBST3097B03 H09:SCUTST3088D12 H10:SCSBST3098E09 H11:SCUTST3089C07 H12:SCSBST3099D05 H13:SCUTST3090C07 H14:SCSBST3100A09 H15:SCUTST3091C04 H16:SCSBST3100F06 H17:SCUTST3091G07 H18:SCSBST3101E06 H19:SCUTST3092D12 H20:SCSBST3102C05 H21:SCSBST3093A10 H22:SCBGST3103A07 H23:SCSBST3093E12 $\mathrm{H} 24$ :SCBGST3103H10 101:SCCCST2003D09 102:SCSFST3074G01 103:SCCCST2004E04 104:SCSFST3075E04 105:SCCCST3001B06 106:SCSFST3076E02 107:SCCCST3001G10 108:SCSFST3077C10 109:SCCCST3002F05 110:SCSFST3078A07 I11:SCCCST3003E01 I12:SCSFST3079A10 I13:SCCCST3004D02 114:SCSFST3079F05 115:SCCCST3005C04 I16:SCSFST3081A11 I17:SCCCST3006C07 I18:SCSFST3082A07 I19:SCCCST3006H10 120:SCSFST3082F05 121:SCSFST3073D12
122:SCCCST3083E04 123:SCSFST3074D01 124:SCUTST3084D09 J01:SCUTST3085B11 J02:SCSBST3094G06 J03:SCUTST3086B04 J04:SCSBST3095C09 J05:SCUTST3086F11 J06:SCSBST3096A08 J07:SCUTST3087H07 J08:SCSBST3097C08 J09:SCUTST3088E02 J10:SCSBST3098E12 J11:SCUTST3089C09 J12:SCSBST3099D08 J13:SCUTST3090C08 J14:SCSBST3100B06 J15:SCUTST3091C09 J16:SCSBST3100G06 J17:SCUTST3091G08 J18:SCSBST3101F03 J19:SCUTST3092F01 J20:SCSBST3102D02 J21:SCSBST3093B06 J22:SCBGST3103B01 J23:SCSBST3093F06 J24:SCBGST3104A02 K01:SCCCST2003D12 K02:SCSFST3074G07 K03:SCCCST2004E05 K04:SCSFST3075H02 K05:SCCCST3001C08 K06:SCSFST3076G09 K07:SCCCST3001H10 K08:SCSFST3077C11 K09:SCCCST3002F09 K10:SCSFST3078B04 K11:SCCCST3003H01 K12:SCSFST3079A12 K13:SCCCST3004E06 K14:SCSFST3079G05 K15:SCCCST3005C07 K16:SCSFST3081B10 K17:SCCCST3006D02 K18:SCSFST3082B01 
K19:SCCCST3006H12 K20:SCSFST3082H01 K21:SCSFST3073F04 K22:SCCCST3083E07 K23:SCSFST3074D03 K24:SCUTST3084D12 L01:SCUTST3085C03 L02:SCSBST3094H06 L03:SCUTST3086B09 L04:SCSBST3095D11 L05:SCUTST3086G08 L06:SCSBST3096B09 L07:SCUTST3088A05 L08:SCSBST3097E03 L09:SCUTST3088E11 L10:SCSBST3098F02 L11:SCUTST3089D01 L12:SCSBST3099E06 L13:SCUTST3090F08 L14:SCSBST3100C06 L15:SCUTST3091D02 L16:SCSBST3100G10 L17:SCUTST3092B09 L18:SCSBST3101G12 L19:SCUTST3092F06 L20:SCSBST3102E01 L21:SCSBST3093C10 L22:SCBGST3103B06 L23:SCSBST3093G10 L24:SCBGST3104A03 M01:SCCCST2003E03 M02:SCSFST3074H05 M03:SCCCST2004G01 M04:SCSFST3076A03 M05:SCCCST3001C11 M06:SCSFST3076H12 M07:SCCCST3002B11 M08:SCSFST3077D04 M09:SCCCST3002F12 M10:SCSFST3078E06 M11:SCCCST3003H03 M12:SCSFST3079B04
M13:SCCCST3004H05 M14:SCSFST3080A03 M15:SCCCST3005C10 M16:SCSFST3081E10 M17:SCCCST3006F09 M18:SCSFST3082B08 M19:SCSFST3073A07 M20:SCSFST3082H06 M21:SCSFST3073F10 M22:SCCCST3083F09 M23:SCSFST3074D06 M24:SCUTST3084F04 N01:SCUTST3085E04 N02:SCSBST3094H07 N03:SCUTST3086D02 N04:SCSBST3095E04 N05:SCUTST3086H01 N06:SCSBST3096C04 N07:SCUTST3088A07 N08:SCSBST3097F11 N09:SCUTST3088G11 N10:SCSBST3098G01 N11:SCUTST3089E10 N12:SCSBST3099F02 N13:SCUTST3090G09 N14:SCSBST3100C07 N15:SCUTST3091D07 N16:SCSBST3101A01 N17:SCUTST3092C01 N18:SCSBST3101H09 N19:SCUTST3092F08 N20:SCSBST3102E06 N21:SCSBST3093D01 N22:SCBGST3103C06 N23:SCSBST3093G11 N24:SCBGST3104B03 O01:SCCCST2003F04 O02:SCSFST3075A02 O03:SCCCST2004G03 O04:SCSFST3076A06 O05:SCCCST3001D04 O06:SCSFST3077A03
O07:SCCCST3002C10 O08:SCSFST3077D07 O09:SCCCST3002G01 O10:SCSFST3078E07 O11:SCCCST3003H06 O12:SCSFST3079B10 013:SCCCST3004H06 O14:SCSFST3080G05 O15:SCCCST3005E08 O16:SCSFST3081F05 017:SCCCST3006G04 O18:SCSFST3082D02 O19:SCSFST3073A11 O20:SCCCST3083A06 O21:SCSFST3073F11 O22:SCCCST3083G06 O23:SCSFST3074D11 O24:SCUTST3084F06 P01:SCUTST3085E06 P02:SCSBST3094H08 P03:SCUTST3086D09 P04:SCSBST3095E05 P05:SCUTST3087C04 P06:SCSBST3096D01 P07:SCUTST3088B01 P08:SCSBST3097H01 P09:SCUTST3088H07 P10:SCSBST3098G09 P11:SCUTST3089F02 P12:SCSBST3099F11 P13:SCUTST3090G10 P14:SCSBST3100C08 P15:SCUTST3091D12 P16:SCSBST3101A12 P17:SCUTST3092C07 P18:SCSBST3102A07 P19:SCUTST3092G01 P20:SCSBST3102G07 P21:SCSBST3093D07 P22:SCBGST3103E10 P23:SCSBST3094B08 P24:SCBGST3104B12 
A01:SCBGST3104C03 A02:SCBGST3111G05 A03:SCBGST3104F08 A04:SCBGST3112D07 A05:SCBGST3105C03 A06:SCQSST3113C09 A07:SCBGST3106D04 A08:SCQSST3114B03 A09:SCBGST3106G09 A10:SCQSST3114E08 A11:SCBGST3108B01 A12:SCQSST3115A12 A13:SCBGST3108C09 A14:SCQSST3115E04 A15:SCBGST3109C07 A16:SCQSST3116C01 A17:SCBGST3110C04 A18:SCQSST3116H09 A19:SCBGST3110F02 A20:SCSGST3117D05 A21:SCBGST3111A09 A22:SCSGST3118D10 A23:SCBGST3111C12 A24:SCSGST3118H09 B01:SCSGST3119D05 B02:SCQGST3126A07 B03:SCSGST3120A03 B04:SCQGST3126G05 B05:SCSGST3120C07 B06:SCUTST3127F05 B07:SCSGST3120F03 B08:SCUTST3127H10 B09:SCSGST3121A01 B10:SCUTST3128E01 B11:SCSGST3121D06 B12:SCUTST3129E06 B13:SCSGST3121G02 B14:SCUTST3130D10 B15:SCQGST3122E03 B16:SCUTST3130G09 B17:SCQGST3123E06
B18:SCUTST3131G02 B19:SCQGST3124A10 B20:SCBFST3132A03 B21:SCQGST3124F05 B22:SCBFST3132F11 B23:SCQGST3125E04 B24:SCBFST3133A01 C01:SCBGST3104C11 C02:SCBGST3111G11 C03:SCBGST3104G04 C04:SCBGST3112E12 C05:SCBGST3105E03 C06:SCQSST3113D04 C07:SCBGST3106D11 C08:SCQSST3114C01 C09:SCBGST3106G11 C10:SCQSST3114G02 C11:SCBGST3108B07 C12:SCQSST3115B02 C13:SCBGST3108D07 C14:SCQSST3115E06 C15:SCBGST3109D05 C16:SCQSST3116C10 C17:SCBGST3110C10 C18:SCSGST3117B08 C19:SCBGST3110G02 C20:SCSGST3117F05 C21:SCBGST3111A11 C22:SCSGST3118E04 C23:SCBGST3111D03 C24:SCSGST3118H10 D01:SCSGST3119E03 D02:SCQGST3126A12 D03:SCSGST3120A06 D04:SCQGST3126H11 D05:SCSGST3120C09 D06:SCUTST3127F08 D07:SCSGST3120F07 D08:SCUTST3128A04 D09:SCSGST3121A10 D10:SCUTST3128E09
D11:SCSGST3121D09 D12:SCUTST3129F01 D13:SCSGST3121G10 D14:SCUTST3130F01 D15:SCQGST3122E11 D16:SCUTST3130H01 D17:SCQGST3123E11 D18:SCUTST3131G03 D19:SCQGST3124C03 D20:SCBFST3132A04 D21:SCQGST3124G07 D22:SCBFST3132G01 D23:SCQGST3125E07 D24:SCBFST3133A02 E01:SCBGST3104D04 E02:SCBGST3111H03 E03:SCBGST3104H11 E04:SCBGST3112F01 E05:SCBGST3105E08 E06:SCQSST3113D06 E07:SCBGST3106E01 E08:SCQSST3114C05 E09:SCBGST3106H06 E10:SCQSST3114H03 E11:SCBGST3108B10 E12:SCQSST3115B12 E13:SCBGST3108E12 E14:SCQSST3115E09 E15:SCBGST3109D12 E16:SCQSST3116E05 E17:SCBGST3110C12 E18:SCSGST3117B12 E19:SCBGST3110G10 E20:SCSGST3117F11 E21:SCBGST3111B03 E22:SCSGST3118E05 E23:SCBGST3111D06 E24:SCSGST3119A07 F01:SCSGST3119F03 F02:SCQGST3126C03 F03:SCSGST3120A07 
F04:SCUTST3127A02

F05:SCSGST3120C12

F06:SCUTST3127F09

F07:SCSGST3120G02

F08:SCUTST3128A09

F09:SCSGST3121B02

F10:SCUTST3128F05

F11:SCSGST3121D10

F12:SCUTST3129G12

F13:SCSGST3121H01

F14:SCUTST3130F03

F15:SCQGST3123A01

F16:SCUTST3130H06

F17:SCQGST3123F11

F18:SCUTST3131G04

F19:SCQGST3124D03

F20:SCBFST3132A08

F21:SCQGST3124H11

F22:SCBFST3132G06

F23:SCQGST3125E10

F24:SCBFST3133A06

G01:SCBGST3104D08

G02:SCBGST3112A09

G03:SCBGST3105A02

G04:SCBGST3112F02

G05:SCBGST3105H05

G06:SCQSST3113F05

G07:SCBGST3106E02

G08:SCQSST3114C11

G09:SCBGST3107A01

G10:SCQSST3114H08

G11:SCBGST3108C02

G12:SCQSST3115C01

G13:SCBGST3108F09

G14:SCQSST3115F05

G15:SCBGST3109F11

G16:SCQSST3116E07

G17:SCBGST3110D09

G18:SCSGST3117C06

G19:SCBGST3110H05

G20:SCSGST3117G09

G21:SCBGST3111B04

G22:SCSGST3118E11

G23:SCBGST3111E01

G24:SCSGST3119A08
H01:SCSGST3119F06

H02:SCQGST3126E03

H03:SCSGST3120B03

H04:SCUTST3127B11

H05:SCSGST3120D09

H06:SCUTST3127F11

H07:SCSGST3120G06

H08:SCUTST3128B05

H09:SCSGST3121B06

H10:SCUTST3128F07

H11:SCSGST3121E03

H12:SCUTST3129H10

H13:SCSGST3121H07

H14:SCUTST3130F04

H15:SCQGST3123C04

H16:SCUTST3130H07

H17:SCQGST3123F12

H18:SCUTST3131H01

H19:SCQGST3124D11

H20:SCBFST3132C10

H21:SCQGST3125B07

H22:SCBFST3132G08

H23:SCQGST3125F02

H24:SCBFST3133B05

I01:SCBGST3104D10

102:SCBGST3112B10

I03:SCBGST3105A03

104:SCBGST3112H12

105:SCBGST3105H07

106:SCQSST3113F09

107:SCBGST3106E07

I08:SCQSST3114D01

109:SCBGST3107B08

I10:SCQSST3114H09

I11:SCBGST3108C04

I12:SCQSST3115C06

I13:SCBGST3108H05

I14:SCQSST3115F07

115:SCBGST3109H08

I16:SCQSST3116G12

I17:SCBGST3110D12

I18:SCSGST3117C08

I19:SCBGST3110H06

120:SCSGST3117H05

121:SCBGST3111B08
122:SCSGST3118F01 123:SCBGST3111E10 124:SCSGST3119B03 J01:SCSGST3119F07 J02:SCQGST3126E09 J03:SCSGST3120B07 J04:SCUTST3127D03 J05:SCSGST3120D12 J06:SCUTST3127G01 J07:SCSGST3120G11 J08:SCUTST3128B07 J09:SCSGST3121C03 J10:SCUTST3128G06 J11:SCSGST3121E07 J12:SCUTST3130A02 J13:SCSGST3121H10 J14:SCUTST3130F09 J15:SCQGST3123C08 J16:SCUTST3130H09 J17:SCQGST3123H12 J18:SCUTST3131H03 J19:SCQGST3124E04 J20:SCBFST3132D09 J21:SCQGST3125C01 J22:SCBFST3132G09 J23:SCQGST3125F05 J24:SCBFST3133B06 K01:SCBGST3104E03 K02:SCBGST3112B11 K03:SCBGST3105A04 K04:SCQSST3113A04 K05:SCBGST3105H08 K06:SCQSST3113H01 K07:SCBGST3106E12 K08:SCQSST3114D03 K09:SCBGST3107E01 K10:SCQSST3115A01 K11:SCBGST3108C05 K12:SCQSST3115C07 K13:SCBGST3109A04 K14:SCQSST3115G05 K15:SCBGST3109H09 K16:SCQSST3116H01 K17:SCBGST3110E02 K18:SCSGST3117C09 
K19:SCBGST3110H10 K20:SCSGST3117H11 K21:SCBGST3111C04 K22:SCSGST3118F03 K23:SCBGST3111F02 K24:SCSGST3119C02 L01:SCSGST3119F11 L02:SCQGST3126E12 L03:SCSGST3120B08 L04:SCUTST3127D05 L05:SCSGST3120E04 L06:SCUTST3127H03 L07:SCSGST3120H03 L08:SCUTST3128C06 L09:SCSGST3121C08 L10:SCUTST3129A01 L11:SCSGST3121E11 L12:SCUTST3130C10 L13:SCQGST3122A07 L14:SCUTST3130F12 L15:SCQGST3123D08 L16:SCUTST3131A12 L17:SCQGST3124A02 L18:SCUTST3131H06 L19:SCQGST3124E05 L20:SCBFST3132E02 L21:SCQGST3125C05 L22:SCBFST3132H01 L23:SCQGST3125G06 L24:SCBFST3133B07 M01:SCBGST3104F03 M02:SCBGST3112C01 M03:SCBGST3105A06 M04:SCQSST3113A05 M05:SCBGST3105H12 M06:SCQSST3114A02 M07:SCBGST3106F01 M08:SCQSST3114E01 M09:SCBGST3107F06 M10:SCQSST3115A03 M11:SCBGST3108C07 M12:SCQSST3115D10
M13:SCBGST3109A11 M14:SCQSST3116B02 M15:SCBGST3110B01 M16:SCQSST3116H05 M17:SCBGST3110E10 M18:SCSGST3117C10 M19:SCBGST3111A04 M20:SCSGST3118A02 M21:SCBGST3111C07 M22:SCSGST3118F06 M23:SCBGST3111F08 M24:SCSGST3119C04 N01:SCSGST3119G09 N02:SCQGST3126F06 N03:SCSGST3120B09 N04:SCUTST3127E11 N05:SCSGST3120E07 N06:SCUTST3127H07 N07:SCSGST3120H06 N08:SCUTST3128D05 N09:SCSGST3121C12 N10:SCUTST3129B06 N11:SCSGST3121F05 N12:SCUTST3130D05 N13:SCQGST3122A10 N14:SCUTST3130G02 N15:SCQGST3123D10 N16:SCUTST3131B08 N17:SCQGST3124A06 N18:SCUTST3131H12 N19:SCQGST3124E12 N20:SCBFST3132E08 N21:SCQGST3125C08 N22:SCBFST3132H06 N23:SCQGST3125G09 N24:SCBFST3133C04 O01:SCBGST3104F06 O02:SCBGST3112D01 O03:SCBGST3105B02 O04:SCQSST3113A12 O05:SCBGST3106C01 O06:SCQSST3114A10
O07:SCBGST3106G07 O08:SCQSST3114E04 O09:SCBGST3107G04 O10:SCQSST3115A05 011:SCBGST3108C08 O12:SCQSST3115E03 O13:SCBGST3109B06 O14:SCQSST3116B04 O15:SCBGST3110B06 O16:SCQSST3116H07 O17:SCBGST3110E12 O18:SCSGST3117C11 O19:SCBGST3111A05 O20:SCSGST3118C09 O21:SCBGST3111C11 O22:SCSGST3118G07 O23:SCBGST3111F11 O24:SCSGST3119D02 P01:SCSGST3119G10 P02:SCQGST3126G01 P03:SCSGST3120B10 P04:SCUTST3127E12 P05:SCSGST3120F02 P06:SCUTST3127H08 P07:SCSGST3120H11 P08:SCUTST3128D10 P09:SCSGST3121D03 P10:SCUTST3129E03 P11:SCSGST3121F09 P12:SCUTST3130D06 P13:SCQGST3122E02 P14:SCUTST3130G07 P15:SCQGST3123D11 P16:SCUTST3131E02 P17:SCQGST3124A07 P18:SCBFST3132A02 P19:SCQGST3124F04 P20:SCBFST3132E10 P21:SCQGST3125D12 P22:SCBFST3132H10 P23:SCQGST3126A05 P24:SCBFST3133D04 


\section{REFERÊNCIAS BIBLIOGRÁFICAS}

ABE, K.; EMORI, Y.; KONDO, H. et al. Molecular cloning of a cysteine proteinase inhibitor of rice (oryzacystatin) - Homology with animal cystatins and transient expression in the ripening process of rice seeds. Journal of Biological Chemistry, v.262, p.16793-16797, 1987a.

ABE, M.; KONDO, H.; ARAI, S. Purification and characterization of a rice cysteine proteinase inhibitor. Agricultural and Biological Chemistry, v.51, p.2763-2768, 1987b.

ABE, M.; ABE, K.; KUDORA, M. et al. Corn kernel cysteine proteinase inhibitor as novel cystatin superfamily member of plant origin. European Journal of Biochemistry, v.209, p.933-937, 1992.

ABEL, S.; OELLER, P.W.; THEOLOGIS, A. Early auxin-induced genes encode short lived nuclear proteins. Proceedings of the National Academy of Science of the United States of America, v.91, p.326-330, 1994.

ABELES, F.B.; MORGAN, P.W.; SALTVEIT, M.E.J. Ethylene in Plant Biology. San Diego: Academic Press, 1992. 414p.

ABU-GOUKH, A.A.; LABAVITCH, J.M. The in vivo role of 'Bartlett' pear fruit polygalacturonase inhibitors. Physiological and Molecular Plant Pathology, v.23, p.123-135, 1983.

ADAMS, M.D.; KELLEY, J.M.; GOCAYNE, J.D. et al. Complementary DNA sequencing: expressed sequence tags and human genome project. Science, v.252, p.1651-1656, 1991. 
AGRAWAL, G.K.; J.W.A., N.; RAKWAL, R. A novel rice (Oriza sativa L.) acidic PR1 gene highly responsive to cut, jasmonic acid, ethylene and protein phosphatase inhibitors. Biochemical and Biophysical Research Communications, v.274, p.157-165, 2000.

ALBORN, H.T.; TURLINGS, T.C.J.; JONES, T.H. et al. An elicitor of plant volatiles from beet armyworm oral secretion. Science, v.276, p.945-944, 1997.

ALTERTHUM, F.; CARVALHAL, M.L. Crescimento bacteriano. IN: TRABULSI, L.R.; ALTERTHUM, F.; GOMPERTZ, O.F. et al. (Ed.). Microbiologia. São Paulo: Editora Atheneu, 2000. cap.4. 586p.

APPEL, H.M. Phenolics in ecological interactions: the importance of oxidation. Journal of Chemical Ecology, v.19, p.1521-1551, 1993.

ARIMURA, G.; TASHIRO, K.; KUHARA, S. et al. Gene responses in bean leaves induced by herbivory and by herbivore-induced volatiles. Biochemical and Biophysical Research Communications, v.277, p.305310, 2000a.

ARIMURA, G.; OZAWA, R.; SHIMODA, T. et al. Herbivory-induced volatiles elicit defense genes in lima bean leaves. Nature, v.406, p.512-515, 2000b.

ARTECA, R. Plant Growth Substances: Principles and Applications. New York: Chapman \& Hall, 1996. 332p.

ARUMUGANATHAN, K.; EARL, E.D. Nuclear DNA content of some important plant species. Plant Molecular Biology Reporter, v.9, p.208-218, 1991.

ASADA, K. The water-water cycle in chloroplasts: scavenging of active oxygen and dissipation of excess photons. Annual Review of Plant Physiology and Plant Molecular Biology, v.50, p.601-639, 1999.

ASAMIZU, E.; NAKAMURA, Y.; SATO, S. et al. Generation of 7.137 nonredundant expressed sequence tags from a legume, Lotus japonicus. DNA Research, v.7, p.127-130, 2000. 
BALDWIN, D.; CRANE, V.; RICE, D. A comparison of gel-based, nylon filter and microarray techniques to detect differential RNA expression in plants. Current Opinion in Plant Biology, v.2, p.96-103, 1999.

BALDWIN, I.T. Methyl jasmonate-induced nicotine production in Nicotiana attenuata: inducing defenses in the field without wounding. Entomologia Experimentalis et Applicata, v.80, p.213-220, 1996.

BALDWIN, I.T.; PRESTON, C.A. The eco-physiological complexity of plant responses to insect herbivores. Planta, v.208, p.137-145, 1999.

BALDWIN, I.T. An ecologically motivated analysis of plant-herbivore interactions in native tobacco. Plant Physiology, v.127, n.4, p.1449-1458, 2001.

BANEYX, F. Recombinant protein expression in Escherichia coli. Current Opinion in Biotechnology, v.10, p.411-421, 1999.

BELL, E.; MULLET, J.E. Lipoxygenase gene expression is modulated in plants by water deficit, wounding, and methyl jasmonate. Molecular and General Genetics, v.230, p.456-462, 1991.

BENEDETTI, C.E.; XIE, D.; TURNER, J.G. COI1-dependent expression of an Arabidopsis vegetative storage protein in flowers and siliques and in response to coronatine and methyl jasmonate. Plant Physiology, v.109, p.567-572, 1995.

BENNING, C. Biosynthesis and function of the sulfolipid sulfoquinovosyl diacylglycerol. Annual Review of Plant Physiology and Plant Molecular Biology, v.49, p.53-75, 1998.

BENTO, J.M.S. Perdas por insetos na agricultura. Ação Ambiental, v. 2, p.1921, 1999.

BERGER, S. Jasmonate-related mutants of Arabidopsis as tools for studying stress signaling. Planta, v.214, p.497-504, 2002.

BERGEY, D.R.; HOWE, G.A.; RYAN, C.A. Polypeptide signaling for plant defensive genes exhibits analogies to defense signaling in animals. Proceedings of the National Academy of Science of the United States of America, v.93, p.12053-12058, 1996. 
BERGEY, D.R.; RYAN, C.A. Wound- and systemin-inducible calmodulin gene expression in tomato leaves. Plant Molecular Biology, v.40, p.815-823, 1999.

BERNARD, K.; AUPHAN, N.; GRANJEAUD, S. et al. Multiplex messenger assay: simultaneous, quantitative measurement of expression of many genes in the context of T cell activation. Nucleic Acids Research, v.24, p.14351443, 1996.

BERTUCCI, F.; BERNARD, K.; LORIOD, B. et al. Sensitivity issues in DNA array-based expression measurements and performance of nylon microarrays for small samples. Human Molecular Genetics, v.8, n.9, p.1715-1722, 1999.

BIRKENMEIER, G.F.; RYAN, C.A. Wound signaling in tomato plants. Plant Physiology, v.117, p.687-693, 1998.

BIRKETT, M.A. New roles for cis-jasmone as an insect semiochemical and in plant defense. Proceedings of the National Academy of Science of the United States of America, v.97, n.16, p.9329-9334, 2000.

BÖGRE, L.; LIGTERINK, W.; MESKIENE, I. et al. Wounding induces the rapid and transient activation of a specific map kinase pathway. The Plant Cell, v.9, p.75-83, 1997.

BOLTER, C.J.; JONGSMA, M.A. Colorado potato beetles (Leptinotarsa decemlineata) adapt to proteinase inhibitors induced in potato leaves by methyl jasmonate. Journal of Insect Physiology, v.41, p.1071-1079, 1995. BOTELLA, M.A.; XU, Y.; PARVA, T.N. et al. Differential expression of soybean cysteine proteinase inhibitor genes during development and in response to wounding and methyl jasmonate. Plant Physiology, v.112, p.1201-1210, 1996.

BOWN, A.W.; HALL, D.E.; MACGREGOR, K.B. Insect footsteps on leaves stimulate the accumulation of 4-aminobutyrate and can be visualized through increased chlorophyll fluorescence and superoxide production. Plant Physiology, v.129, p.1430-1434, 2002. 
BOX, H.E. Informe preliminar sobre los taladradores de la caña de azúcar (Diatraea spp.) en Venezuela. Maracay: Instituto Nacional de Agricultura, 1952. 93p. Boletín técnico 2.

BRAGA, D.P.V. Caracterização de duas variedades de cana-de-açúcar transformadas geneticamente com o gene que codifica a proteína $\operatorname{cry} I A(B)$ de Bacilus thunrigiensis (Bt) para resistência a Diatraea saccharalis (Lepdoptera: Crambidae). Piracicaba, 2001. 71p. Tese (Mestrado) - Escola Superior de Agricultura "Luiz de Queiroz", Universidade de São Paulo.

BRAGA, D.P.V.; ARRIGONI, E.D.B.; SILVA-FILHO, M.C. et al. Expression of the Cry $1 A b$ protein in genetically modified sugarcane for the control of Diatraea saccharalis (Lepidoptera: Crambidae). Journal of New Seeds, v.5, p.209-222, 2003.

BROADWAY, R.M. Dietary proteinase inhibitors alter complement of midgut proteases. Archieves of Insect Biochemistry and Physiology, v.32, n.1, p.39-53, 1996.

BROADWAY, R.M.; DUFFEY, S.S. Plant proteinase inhibitor: mechanism of action and effect on the growth and digestive physiology of larval Heliothis zea and Spodoptera exigua. Journal of Insect Physiology, v.32, p.827833, 1986.

BROGLIE, R.; BROGLIE, K. Chitinases and plant protection. IN: FRITIG, B.; LEGRAND, M. (Ed.). Mechanisms of Plant Defense Responses. Netherlands: Kluwer Academic Publishers, 1993. p.411-421.

BROWSE, J.A.; SOMERVILLE, C. Glycerolipid metabolism: biochemistry and regulation. Annual Review of Plant Physiology and Plant Molecular Biology, v.42, p.467-506, 1991.

CAPY, P.; GASPERI, G.; BIEMONT, C. et al. Stress and transposable elements: co-evolution or useful parasites? Heredity, v.85, p.101-106, 2000. CARLINI, C.R.; GROSSI-DE-SÁ, M.F. Plant toxic proteins with insecticidal properties: a review on their potentialities as bioinsecticides. Toxicon, v.40, p.1515-1539, 2002. 
CARSON, D.L.; BOTHA, F.C. Preliminary analysis of expressed sequence tags for sugarcane. Crop Science, v.40, p.1769-1779, 2000.

CARSON, D.L.; BOTHA, F.C. Genes expressed in sugarcane maturing internodal tissue. Plant Cell Report, v.20, p.1075-1081, 2002.

CARSON, D.L.; HUCKETT, B.I.; BOTHA, F.C. Sugarcane ESTs differentially expressed in immature and maturing internodal tissue. Plant Science, v.162, p.289-300, 2002.

CENTRO DE TECNOLOGIA COPERSUCAR - CTC. Relatório Anual 1996/97. Piracicaba: CTC, 1997. 76p. (Relatório Anual Copersucar)

CHEONG, Y.H.; CHANG, H.S.; GUPTA, R. et al. Transcriptional profiling reveals novel interactions between wounding, pathogen, abiotic stress, and hormonal responses in Arabidopsis. Plant Physiology, v.129, p.661-677, 2002.

CHIANG, H.D.; NORRIS, M.; CIEPIELA, A. et al. Inducible versus constitutive soybean resistence to mexican bean beetle. Journal of Chemical Ecology, v.13, p.741-749, 1987.

CHRISTELLER, J.T.; FARLEY, P.C.; RAMSAY, R.J. et al. Purification, characterization and clonning of an aspartic proteinase inhibitor from squash phloem exudate. European Journal of Biochemistry, v.254, p.160-167, 1998.

COHEN, P.; BOUABOULA, M.; BARON, V. et al. Monitoring cellular responses to Listeria monocytogenes with oligonucleotide arrays. The Journal of Biological Chemistry, v.275, p.11181-11190, 2000.

CONCONI, A.; MIQUEL, M.; BROWSE, J.A. et al. Intracellular levels of free linoleic and linoleic acid increase in tomato leaves in response to wounding. Plant Physiology, v.111, p.797-803, 1996.

CONSTABEL, C.P.; BERGEY, D.R.; RYAN, C.A. Systemin activates synthesis of wound-inducible tomato leaf polyphenol oxidase via the octadecanoid defense signaling pathway. Proceedings of the National Academy of Science of the United States of America, v.92, p.407-411, 1995. 
CONSTABEL, C.P.; YIP, L.; RYAN, C.A. Prosystemin from potato, black nightshade and bell pepper: primary structure and biological activity of predicted systemin polypeptides. Plant Molecular Biology, v.36, p.55-62, 1998.

CONSTABEL, C.P.; LYNN, Y.; PATTON, J.J. et al. Polyphenol oxidase from hybrid poplar. Cloning and expression in response to wounding and herbivory. Plant Physiology, v.124, p.285-295, 2000.

COX, J.M. Applications of nylon membrane arrays to gene expression analysis. Journal of Immunological Methods, v.250, p.3-13, 2001.

CREELMAN, R.A.; MULLET, J.E. Biosynthesis and action of jasmonates in plants. Annual Review of Plant Physiology and Plant Molecular Biology, v.41, p.355-381, 1997.

CREELMAN, R.A.; TIERNEY, M.L.; MULLET, J.E. Jasmonic acid/methyl jasmonate accumulate in wounded soybean hypocotyls and modulate wound gene expression. Proceedings of the National Academy of Science of the United States of America, v.89, p.4938-4941, 1992.

CUSHMAN, J.C.; BOHNERT, H.J. Genomic approaches to plant stress tolerance. Current Opinion in Plant Biology, v.3, p.117-124, 2000.

DAMMANN, C.; ROJO, E.; SÁNCHES-SERRANO, J.J. Abscisic acid and jasmonic acid activate wound-inducible genes in potato through separate, organ-specific signal transduction pathways. The Plant Journal, v.11, p.773-782, 1997.

DANIELS, J.; ROACH, B.T. Taxonomy and evolution. IN: HEINZ, D. J. (Ed.). Sugarcane improvement trough breeding. Amsterdam: Elsevier Press, 1987. cap.2. pp.7-87.

DaSILVA, J.A.G.; SORRELLS, M.E.; BURNQUIST, W.L. et al. RFLP linkage map and genome analysis of Saccharum spontaneum. Genome, v.36, p.782-791, 1993.

DEHIO, C.; DE BRUIJN, F.J. The early nodulin gene SrENOD2 from Sesbania rostrata is inducible by cytokinin. The Plant Journal, v.2, p.117-128, 1992. 
DESPREZ, T.; AMSELEM, J.; CABOCHE, M. et al. Differential gene expression in Arabidopsis monitored using cDNA arrays. The Plant Journal, v.14, p.643-652, 1998.

DeWALD, D.B.; SADKA, A.; MULLET, J.E. Sucrose modulation of soybean Vsp gene expression is inhibited by auxin. Plant Physiology, v.104, p.439-444, 1994.

DIATCHENKO, L.; LAU, Y.C.; CAMPBELL, A.P. et al. Suppression subtractive hybridization: a method for generating differentially regulated or tissuespecific cDNA probes and libraries. Proceedings of the National Academy of Science of the United States of America, v.93, p.6025-6030, 1996.

DOOSTDAR, H.; BULLOCK, R.C.; ADAIR, R.A. et al. When to spray? Population dynamics of Diaprepes abbreviatus in Indian River County citrus groves. Diaprepes Task Force Meeting. Lake Alfred: University of Florida, 2002. p.?

DUAN, X.; LI, X.; XUE, Q. et al. Transgenic rice plants harboring an introduced potato proteinase inhibitor II gene are insect resistant. Nature Biotechnology, v.14, p.494-498, 1996.

ECKMANN, L.; SMITH, J.R.; HOUSLEY, M.P. et al. Analysis by high density cDNA arrays of altered gene expression in human intestinal epithelial cells in response to infection with the invasive enteric bacteria Salmonella. The Journal of Biological Chemistry, v.275, p.14084-14094, 2000.

EL-BATAL, A.I.; ABO-STATE, M.A.; SHIHAB, A. Phenylalanine ammonia lyase production by gamma irradiated and analog-resistant mutants of Rhodotorula glutinis. Acta Microbiologica Polonica, v.49, p.51-61, 2000.

FALCO, M.C.; MARBACH, P.A.S.; POMPERMAYER, P. et al. Mechanisms of sugarcane response to herbivory. Genetics and Molecular Biology, v.24, p.113-122, 2001.

FALCO, M.C.; SILVA-FIHO, M.C. Searching for insect resistance genes in sugarcane. Proceedings of the International Society of Sugar Cane Technologists, v.24, p.547-550, 2001. 
FALCO, M.C.; SILVA-FILHO, M.C. Expression of soybean proteinase inhibitors in transgenic sugarcane plants: Effects on natural defense against Diatraea saccharalis. Plant Physiology and Biochemistry, v.41, p.761-766, 2003.

FARMER, E.E.; RYAN, C.A. Interplant communication: airborne methyl jasmonate induces synthesis of proteinase inhibitors in plants leaves. Proceedings of the National Academy of Science of the United States of America, v.87, p.7713-7716, 1990.

FARMER, E.E.; WEBER, H.; VOLLENWEIDER, S. Fatty acid signaling in Arabidopsis. Planta, v.206, p.167-174, 1998.

FELIX, G.; GROSSKOPF, D.G.; REGENASS, M. et al. Elicitor-induced ethylene biosynthesis in tomato cells. Characterization and use as a bioassay for elicitor action. Plant Physiology, v.97, p.19-25, 1991.

FELIX, J.M; DRUMMOND, R.D.; NOGUEIRA, F.T.S. et al. Genoma funcional: uso de arranjos de DNA em náilon para a análise da expressão gênica em larga escala. Biotecnologia Ciência \& Desenvolvimento, v.24, p.60-67, 2002.

FELTON, G.W.; DONATO, K.K.; DELVECCHIO, R.J. et al. Activation of foliar oxidases by insect feeding reduces nutritive quality of dietary protein for foliage for noctuid herbivores. Journal of Chemical Ecology, v.15, p.26672693, 1989.

FELTON, G.W.; DONATO, K.K.; BROADWAY, R. et al. Impact of oxidized plant phenolics on the nutritional quality of dietary protein to a noctuid herbivore, Spodoptera exigua. Journal of Insect Physiology, v.38, p.277-285, 1992.

FERNANDES, A.C. Produção e produtividade da cana-de-açúcar no Brasil. IN: CONGRESSO NACIONAL DA SOCIEDADE DE TÉCNICOS AÇUCAREIROS E ALCOOLEIROS DO BRASIL - STAB, 6, Maceió, 1996. Anais. Maceió: STAB, 1996. p.602-612. 
FIDANTSEF, A.L.; STOUT, M.J.; THALER, J.S. et al. Signal interactions in pathogen and insect attack: expression of lipoxygenase, proteinase inhibitor II and pathogenesis-related protein P4 in the tomato, Lycopersicon esculentum. Physiological and Molecular Plant Pathology, v. 54, p.97114, 1999.

FNP CONSULTORIA \& COMÉRCIO. Agrianual 2000: Anuário da agricultura brasileira. São Paulo, 2000. 546p.

FORDYCE, J.A.; AGRAWAL, A.A. The role of plant trichomes and caterpillar group size on growth and defense of the pipevine swallowtail Battus philenor. The Journal of Animal Ecology, v.70, n.6, p.997-1005, 2001.

FOURNIER, J.; POUENAT, M.L.; RICKAUER, M. et al. Purification and characterization of elicitor-induced lipoxygenase in tobacco cells. The Plant Journal, v.3, p.63-70, 1993.

FRANCO, O.L.; RIGDEN, D.J.; MELO, F.R. et al. Plant $\alpha$-amylase inhibitors and their interaction with insect $\alpha$-amylases. European Journal of Biochemistry, v.269, p.397-412, 2002.

GAI, X.; LAL, S.; XING, L. et al. Gene discovery using the maize genome database ZmDB. Nucleic Acids Research, v.28, n.1, p.94-96, 2000.

GALLO, D.; NAKANO, O.; SILVEIRA NETO, S. et al. Pragas das plantas e seu controle. IN: GALLO, D.; NAKANO, O.; SILVEIRA NETO, S. et al. (Ed.). Entomologia Agrícola. Piracicaba: FEALQ, 2002. 920 p.

GAMAS, P.; NIEBEL. F.D.C.; LESCURE, N. et al. Use of a subtractive hybridization approach to identify new Medicago truncatula genes induced during root nodule development. Molecular Plant-Microbe Interactions, v.9, p.233-242, 1996.

GASCH, A.P.; HUANG, M.; METZNER,S. Genomic expression responses to DNA-damaging agents and the regulatory role of the yeast ATR homolog Mec1p. Molecular Biology of the Cell, v.12, p.2987-3003, 2001. 
GATEHOUSE, A.M.R.; BOULTER, D. Assessment of the antimetabolic effects of trypsin inhibitors from cowpea (Vigna unguiculata) and other legumes on development of the bruchid beetle Callosobruchus maculatus. Journal of the Science of Food and Agriculture, v.34, p.345-350, 1983.

GATEHOUSE, A.M.R.; GATEHOUSE, J.A. Identifying proteins with insecticidal activity: Use of encoding genes to produce insect-resistant transgenic crops. Pesticide Science, v.52, p.165-175, 1998.

GAZZONI, D.L.; HÜLSMEYER, A.; HOFFMANN-CAMPO, C.B. Efeito de diferentes doses de rutina e de quercetina na biologia de Anticarsia gemmatalis Hübner, 1818 (Lep., Noctuidae). Revista da Pesquisa Agropecuária Brasileira On line, v.32, n.7, 1997.

GEERTS, A.; FELTKAMP, D.; ROSAHL, S. Expression of lipoxygenase in wounded tubers of Solanum tuberosum L. Plant Physiology, v.105, p.269277, 1994.

GLAZEBROOK, J. Genes controlling expression of defense responses in Arabidopsis. Current Opinion in Plant Biology, v.2, p.280-286, 1999.

GOMES, F.P. Curso de estatística experimental. Piracicaba: Frederico Pimentel Gomes, 2000. 477 p.

GRESS, T.M.; HOHEISEL, J.D.; LENNON, G.G. et al. Hybridization fingerprinting of high-density cDNA-library arrays with cDNA pools derived from whole tissues. Mammalian Genome, v.3, p.609-619, 1992.

GRISON, R.; GREZES-BESSET, B.; SCHEIDER, M. et al. Field tolerance to fungal pathogens of Brassica napus constitutively expressing a chimeric chitinase gene. Nature Biotechnology, v.14, p.643-646, 1996.

GROSSMAN, A.; TAKAHASHI, H. Macronutrient utilization by photosynthetic eukaryotes and the fabric of interactions. Annual Review of Plant Physiology and Plant Molecular Biology, v.52, p.163-210, 2001.

GUAGLIUMI, P. Pragas da cana-de-açúcar (Nordeste do Brasil). Rio de Janeiro: IAA, 1972/73. 622p. 
GUNDLACH, H.; MÜELLER, M.J.; KUTCHAN, T.M. et al. Jasmonic acid is a signal inducer in elicitor-induced plant-cell cultures. Proceedings of the National Academy of Science of the United States of America, v.89, p.2389-2393, 1992.

HALITSCHKE, R.; SCHITTKO, U.; POHNERT, G. et al. Molecular interactions between the specialist herbivore Manduca sexta (Lepidoptera, Sphingidae) and its natural host Nicotiana attenuata. III. Fatty acid-amino acid conjugates in herbivore oral secretions are necessary and sufficient for herbivorespecific plat responses. Plant Physiology, v.125, p.711-717, 2001.

HALITSCHKE, R.; GASE, K.; HUI, D. et al. Molecular interactions between the specialist herbivore Manduca sexta (Lepidoptera, Sphingidae) and its natural host Nicotiana attenuata. VI. Microarray analysis reveals that most herbivorespecific transcriptional changes are mediated by fatty acid-amino acid conjugates. Plant Physiology, v.131, p.1894-1902, 2003.

HARBORNE, J.B. Flavonoid pigments. In: ROSENTHAL, G.A.; BEREMBAUM, M.R. (Ed.). Herbivores and their interaction with secondary metabolites. London: Academic Press, 1991. p.389-429.

HARUTA, M.; MAJOR, I.T.; CHRISTOPHER, M.E. et al. A Kunitz trypsin inhibitor gene family from trembling aspen (Populus tremuloides Michx.): cloning, functional expression, and induction by wounding and herbivory. Plant Molecular Biology, v.46, n.3, p.347-359, 2001.

HEIL, M.; BALDWIN, I.T. Fitness costs of induced resistance: emerging experimental support for a slippery concept. Trends in Plant Science, v.7, p.61-67, 2002.

HEITZ, T.; BERGEY, D.R.; RYAN, C.A. A gene encoding a chloroplast-targeted lipoxygenase in tomato leaves is transiently induced by wounding, systemin, and methyl jasmonate. Plant Physiology, v.114, p.1085-1093, 1997. 
HEMBERGER, M.; CROSS, J.C.; ROPERS, H.H. et al. Unigene cDNA arraybased monitoring of transcriptome changes during mouse placental development. Proceedings of the National Academy of Science of the United States of America, v.98, p.13126-13131, 2001.

HERDE, O.; ATZORN, R.; FISAHN, J. et al. Localized wounding by heat initiates the accumulation of proteinase inhibitor II in abscisic acid-deficient plants by triggering jasmonic acid biosynthesis. Plant Physiology, v.112, p.853-860, 1996.

HERMSMEIER, D.; SCHITTKO, U.; BALDWIN, I.T. Molecular interactions between the specialist herbivore Manduca sexta (Lepidoptera, Sphingidae) and its natural host Nicotiana attenuata. I. Large-scale changes in the accumulation of growth- and defense-related plant mRNAs. Plant Physiology, v.125, p.683-700, 2001.

HERVÉ, C.; PERRET, E.; TREMOUSAYGUE, D. et al. Differential screening using high density filters reveals a dramatic change in gene expression at different grown phase in Arabidopsis cell suspension cultures. Plant Physiology and Biochemistry, v.34, n.3, p.425-430, 1996.

HILDEBRAND, D.F. Lipoxygenases. Physiologia Plantarum, v.76, p.249-253, 1989.

HINES, M. E.; OSUALA, C. I.; NIELSEN, S. S. Isolation and partial characterization of a soybean cystatin cysteine proteinase inhibitor of Coleopteran digestive proteolitic activity. Journal of Agricultural and Food Chemistry, v.39, p.1515-1520, 1991.

HOEVEN, R.V.; RONNING, C.; GIOVANNONI, J. et al. Deductions about the number, organization, and evolution of genes in the tomato genome based on analysis of a large expressed sequence tag collection and selective genomic sequencing. The Plant Cell, v.14, p.1441-1456, 2002.

HOGARTH, D. Genetics of sugarcane. IN: HEINZ, D. J. (Ed.). Sugarcane improvement trough breeding. Amsterdam: Elsevier Press, 1987. p.255271. 
HOWE, G.A.; LIGHTNER, J.; BROWSE, J. et al. An octadecanoid pathway mutant (JL5) of tomato is compromised in signaling for defense against insect attack. The Plant Cell, v.8, p.2067-2077, 1996.

HUI, D.; IQBAL, J.; LEHMANN, K. et al. Molecular interactions between the specialist herbivore Manduca sexta (Lepidoptera, Sphingidae) and its natural host Nicotiana attenuata. V. Microarray analysis and further characterization of large-scale changes in herbivore-induced mRNAs. Plant Physiology, v.131, p.1877-1893, 2003.

ICHIKAWA, J.K.; NORRIS, A.; BANGERA, M.G. et al. Interaction of Pseudomonas aeruginosa with epithelial cells: identification of differentially regulated genes by expression microarray analysis of human cDNAs. Proceedings of the National Academy of Science of the United States of America, v.97, p.9659-9664, 2000.

JANZEN, D.H.; RYAN, C.A.; LIENER, I.E. et al. Potentially defensive proteins in mature seeds of 59 species of tropical leguminosae. Journal of Chemical Ecology, v.12, p.1469-1480, 1986.

JONAK, C.; BEISTEINER, D.; BEYERLY, J. et al. Wound-induced expression and activation of wig, a novel glycogen synthase kinase 3. The Plant Cell, v.12, p.1467-1476, 2000.

JONGSMA, M.A.; BOLTER, C. The adaptation of insects to plant protease inhibitors. Journal of Insect Physiology, v.43, n.10, p.885-895, 1997.

JOUANIN, L.; BONADE-BOTTINO, M.; GIRARD, C. et al. Transgenic plants for insect resistance. Plant Science, v.131, p.1-11, 1998.

JUNG, H.W.; HWANG, B.K. Isolation, partial sequencing and expression of pathogenesis-related cDNA genes from pepper leaves infected by Xanthomonas campestris pv. vesicatoria. Molecular Plant-Microbe Interactions, v.13, p.136-142, 2000.

KARBAN, R.; BALDWIN, I.T. Induced responses to herbivory. Illinois: University of Chicago Press, 1997. p.? 
KATO, M.; HAYAKAWA, Y.; HYODO, $\mathrm{H}$. et al. Wound-induced ethylene synthesis and expression and formation of 1-aminocyclopropane-1carboxylate (ACC) synthase, ACC oxidase, phenylalanine ammonia-lyase, and peroxidase in wounded mesocarp tissue of Cucurubita maxima. Plant Cell Physiology, v.41, p.440-447, 2000.

KEPPLER, L.D.; NOVACKY, A. The initiation of membrane lipid peroxidation during bacteria-induced hypersensitive reaction. Physiological and Molecular Plant Pathology, v.30, p.233-245, 1987.

KERNAN, A.; THORNBERG, R.W. Auxin levels regulate the expression of a wound-inducible proteinase inhibitor II-chloramphenicol acetyl transferase gene fusion in vitro and in vivo. Plant Physiology, v.91, p.73-78, 1989.

KESSLER, A.; BALDWIN, I.T. Defensive function of herbivore-induced plant volatile emissions in nature. Science, v.291, p.2141-2144, 2001.

KHAN, J.; BITTNER, M.L.; CHEN, Y. et al. DNA microarray technology: the anticipated impact on the study of human disease. Biochimica et Biophysica Acta, v.1423, p.M17-M28, 1999.

KIM, J.; HARTER, K.; THEOLOGIS, A. Protein-protein interactions among the Aux/IAA proteins. Proceedings of the National Academy of Science of the United States of America, v.94, p.11786-11791, 1997.

KIM, S.; HONG, Y.; AN, C.S. et al. Expression characteristics of serine proteinase inhibitor II under variable environmental stress in hot pepper (Capsicum annuum L.). Plant Science, v.161, p.27-33, 2001.

KING, E.G.; HARTLEY, G.G. Diatraea saccharalis. IN: SINGH, H.P.; MOORE, R.F. (Ed.). Handbook of insect rearing. New York: Elsevier, 1985. p.265270.

KLIEBENSTEIN, D.J.; KROYMANN, J.; BROWN, P. et al. Genetic control of natural variation in Arabidopsis glucosinolate accumulation. Plant Physiology, v.126, n.2, p.8811-8825, 2001. 
$\mathrm{KOCH}$, E.; MEIER, B.M.; EIBEN, H.G. et al. A lipoxygenase from leaves of tomato (Lycopersicon esculentum Mill.) is induced in response to plant pathogenic pseudomonads. Plant Physiology, v.99, p.571-576, 1992.

KORTH, K.L.; DIXON, R.A. Evidence for chewing insect-specific molecular events distinct from a general wound response in leaves. Plant Physiology, v.115, p.1299-1305, 1997.

KOZIAN, D.H.; KIRSCHBAUM, B.J. Comparative gene-expression analysis. Trends in Biotechnology, v.17, p.73-78, 1999.

KUHN, K.M.; DeRISI, J.L.; BROWN, P.O. et al. Global and specific translational regulation in the genomic response of Saccharomyces cerevisae to a rapid transfer from a fermentable to a nonfermentable carbon source. Molecular and Cellular Biology, v.21, p.916-927, 2001.

KUZMA, M.M.; HUNG, S.; LAYZELL, D.B. Role of oxygen in the limitation and inhibition of nitrogenase activity and respiration rate in individual soybean nodules. Plant Physiology, v.101, p.161-169, 1993.

LAFUENTE, M.T.; ZACARIAS, L.; MARTINEZ-TELLEZ, M.A. et al. Phenylalanine ammonia-lyase as related to ethylene in the development of chilling symptoms during cold storage of citrus fruits. Journal of Agricultural and Food Chemistry, v.49, p.6020-6025, 2001.

LARSON, R.A. The antioxidants of higher plants. Phytochemistry, v.27, p.969-978, 1988.

LASHKARI, D.A.; DeRISI, J.L.; McCUSKER, J.H. et al. Yeast microarrays for genome wide parallel genetic and gene expression analysis. Proceedings of the National Academy of Science of the United States of America, v.94, p.13057-13062, 1997.

LENNON, G.G.; LEHRACH, H. Hybridization analyses of arrayed cDNA Libraries. Trends in Genetics, v.7, p.314-317, 1991.

LEÓN, J.; SÁNCHEZ-SERRANO, J.J. Molecular biology of jasmonic acid biosynthesis in plants. Plant Physiology and Biochemistry, v.37, p.373380, 1999. 
LEPLÉ, J.C.; BONADE-BOTTINO, M.; AUGUSTIN, S. et al. Toxicity to Chrysomela tremulae (Coleoptera: Chrysomelidae) of transgenic poplars expressing a cysteine proteinase inhibitor. Molecular Breeding, v.1, p.319328, 1995.

LI, S.; ROSS, D.T.; KADIN, M.E. et al. Comparative genome-scale analysis of gene expression profiles in $\mathrm{T}$ cell lymphoma cells during malignant progression using a complementary DNA microarray. American Journal of Pathology, v.158, p.1231-1237, 2001.

LIANG, P.; PARDEE, A.B. Differential display of eukaryotic messenger RNA by means of the polymerase chain reaction. Science, v.257, p.967-971, 1992.

LORENZO, O.; PIQUERAS, R.; SÁNCHEZ-SERRANO, J.J. et al. Ethylene response factor 1 integrates signals from ethylene and jasmonate pathways in plant defense. The Plant Cell, v.15, p.165-178, 2003.

MA, H.M.; SCHULZE, S.; LEE, S. et al. An EST survey of the sugarcane transcriptome. Theoretical and Applied Genetics, publicação on line (29 nov. 2003).

MAGUIRE, T.L.; GRIMMOND, S.; FORREST, A. et al. Tissue-specifc gene expression in soybean (Glycine max) detected by cDNA microarray analysis. Journal of Plant Physiology, v.159, p.1361-1374, 2002.

MARKHAM, K.R. Flavones, flavonols and their glycosides. In: MARKHAM, K.R. (Ed.). Methods in plant biochemistry. London: Academic Press, 1989. p.197-235.

MARTÍNEZ-TÉLLEZ, M.A.; LAFUENTE, M.T. Effect of high temperature conditioning on ethylene, phenylalanine ammonia lyase, peroxidase and polyphenol oxidase activities in flavedo of chilling 'fortune' fruit. Journal of Plant Physiology, v.150, p.674-678, 1997.

MARUYAMA-NAKASHITA, A.; INOUE, E.; WATANABE-TAKAHASHI, A. et al. Transcriptome profiling of sulfur-responsive genes in arabidopsis reveals global effects of sulfur nutrition on multiple metabolic pathways. Plant Physiology, v.132, p.597-605, 2003. 
MASON, H.S.; MULLET, J.E. Expression of two soybean vegetative storage protein genes during development and in response to water deficit, wounding, and jasmonic acid. The Plant Cell, v.2, p.569-579, 1990.

MATSUOKA, S.; GARCIA, A.A.F; ARIZONO, H. Melhoramento da cana-deaçúcar. IN: BORÉM, A. (Ed.). Melhoramento de espécies cultivadas. Viçosa: UFV, 1999. p.205-251.

MAUCH, F.; KMECL, A.; SCHAFFRATH, U. et al. Mechanosensitive expression of a lipoxygenase gene in wheat. Plant Physiology, v.114, p.1561-1566, 1997.

MAYER, A.M.; HAREL, E. Polyphenol oxidases in plants. Phytochemistry, v.18, p.193-215, 1979.

McCONN, M.; CREELMAN, R.A.; BELL, E. et al. Jasmonate is essential for insect defense in Arabidopsis. Proceedings of the National Academy of Science of the United States of America, v.94, p.5473-5477, 1997.

McGURL, B.; PEARCE, G.; OROZCO-CARDENAS, M. et al. Structure, expression and antisense inhibitor of the systemin precursor gene. Science, v.255, p.1570-1572, 1992.

McGURL, B.; MUKHERJEE, S.; KAHN, M. et al. Characterization of two proteinase inhibitor (ATI) cDNAs from alfafa leaves (Medicago sativa var. Vernema): the expression of ATI genes in response to wounding and soil microorganisms. Plant Molecular Biology, v.27, p.995-1001, 1995.

MELAN, M.A.; DONG, X.; ENDARA, M.E. et al. An Arabidopsis thaliana lipoxygenase gene can be induced by pathogens, abscisic acid, and methyl jasmonate. Plant Physiology, v.101, p.441-450, 1993.

MELLO, M.O.; SILVA-FILHO, M.C. Plant-insect interactions: an evolutionary arms race between two distinct defense mechanisms. Brazilian Journal of Plant Physiology, v.14, p.71-81, 2002.

MELLO, M.O.; TANAKA, A.S.; SILVA-FILHO, M.C. Molecular evolution of Bowman-Birk type proteinase inhibitors in flowering plants. Molecular Phylogenetics and Evolution, v.27, p.103-112, 2003. 
MÉLO, A.B.P. Biologia de Diatraea saccharalis (Fabricius, 1794) (Lepidoptera: Pyralidae) em diferentes temperaturas para determinação das exigências térmicas. Piracicaba, 1984. 101p. Tese (Mestrado) - Escola Superior de Agricultura "Luiz de Queiroz", Universidade de São Paulo.

METCALFE, J.R. The estimation of loss caused by sugar cane moth borers.

IN: METCALFE, R.J. Pest of sugar cane. Amsterdan: Elsevier Publishing, 1969. p.61-75.

MEURIOT, F.; NOQUET, C.; AVICEA, J.C. et al. Methyl jasmonate alters N partitioning, $\mathrm{N}$ reserves accumulation and induces gene expression of a 32$\mathrm{kDa}$ vegetative storage protein that possesses chitinase activity in Medicago sativa taproots. Physiologia Plantarum, v.120, p.113-123, 2004.

MEYER, A.; MIERSCH, O.; BUTTER, C. et al. Occurrence of the plant growth regulator jasmonic acid in plants. Journal of Plant Growth Regulation, v.3, p.1-8, 1984.

MILLES, A.A.L.; MISRA, S.S. The estimation of bacterial power of blood. Journal of Hygiene, v.38, p.732-749, 1938.

MORTON, R.L.; SCHROEDER, H.E.; BATEMAN, K.S. et al. Bean $\alpha$-amylase inhibitor 1 in transgenic peas (Pisum sativum) provides complete protection from pea weevil (Bruchus pisorum) under field conditions. Proceedings of the National Academy of Science of the United States of America, v.97, p.3820-3825, 2000.

MOURA, D.S.; RYAN, C.A. Wound-inducible proteinase inhibitors in pepper. Differential regulation upon wounding, systemin, and methyl jasmonate. Plant Physiology, v.126, p.289-298, 2001.

NADON, R.; SHOEMAKER, J. Statistical issues with microarrays: processing and analysis. Trends in Genetics, v.18, n.5, p.265-271, 2002.

NAP, J.P.; BISSELING, T. The roots of nodulins. Physiologia Plantarum, v.79, p.407-414, 1990.

NAPIER, R.M.; VENIS, M.A. Auxin action and auxin-binding proteins. New Phytologist, v.129, p.167-201, 1995. 
NARUSAKA, Y.; NARUSAKA, M.; SEKI, M. et al. The cDNA microarray analysis using an Arabidopsis pad3 mutant reveals the expression profiles and classification of genes induced by Alternaria brassicicola attack. Plant and Cell Physiology, v.44, p.377-387, 2003.

NEDEVI, E.; HEVRONI, D.; NAOT, D. et al. Numerous candidate plasticityrelated genes revealed by differential cDNA cloning. Nature, v.361, p.718722, 1993.

NEGREIROS, A.N.M.; CARVALHO, M.M.; XAVIER-FILHO, J. et al. The complete amino acid sequence of the major Kunitz trypsin inhibitor from the seeds of Prosopsis juliflora. Phytochemistry, v.30, p.2829-2833, 1991.

NGUYEN, C.; ROCHA, D.; GRANJEAUD, S. et al. Differential gene expression in the murine thymus assayed by quantitative hybridization on arrayed cDNA clones. Genomics, v.29, p.207-216, 1995.

NISHIDA, R. Sequestration of defensive substances from plants by lepidoptera. Annual Review of Entomology, v.47, p.57-92, 2002.

NIZETIC, D.; ZEHETNER, G.; MONACO, A.P. et al. Construction, arrying, and high-density screening of large insert libraries of human chromosomes $X$ and 21: their potential use as reference libraries. Proceedings of the National Academy of Science of the United States of America, v.88, p.3233-3237, 1991.

NOGUEIRA, F.T.S.; DeROSA JÚNIOR., V.E.; MENOSSI, M. et al. RNA expression profiles and data mining of sugarcane response to low temperature. Plant Physiology, v.132, p.1811-1824, 2003.

NOQUET, C.; AVICE, J.C.; OURRY, A. et al. Effects of environmental factors and endogenous signals on $\mathrm{N}$ uptake, $\mathrm{N}$ partitioning and taproot storage protein accumulation in Medicago sativa, Australian Journal of Plant Physiology, v.28, p.279-288, 2001.

O'DONNELL, P.J.; CALVERT, C.; ATZORN, R. et al. Ethylene as a signal mediating the wound response of tomato plants. Science, v.274, p.19141917, 1996. 
OHLROGGE, J.; BENNING, C. Unraveling plant metabolism by EST analysis. Current Opinion in Plant Biology, v.3, p.224-228, 2000.

OLIVEIRA, M.N.S.; OLIVA, M.A.; MARTÍNEZ, C.A. et al. Stomatal sensitivity to $\mathrm{ABA}$ related to $\mathrm{pH}$ and $\mathrm{NO}^{-3}, \mathrm{PO}_{4}^{-3}$ and $\mathrm{Ca}^{+2}$ levels of xylem sap. Brazilian Journal of Plant Physiology, v.14, p.117-123, 2002.

ORLANDO-FILHO, J.; MACEDO, N.; TOKASHI, H. Seja doutor do seu canavial. Arquivo do Agrônomo, n.6, p.1-17, 1994.

OURRY, A.; MacDUFF, J.; VOLENEC, J.J. et al. Nitrogen traffic during plant growth and development. IN: MOROT-GAUDRY, J.F.; LEA, P. (Ed.). Plant Nitrogen. Heidelberg: Springer Verlag, 2001. p 255-273.

PARADIES, I.; KONZE, J.R.; ELSTNER, E.F. Ethylene. Indicator but not inducer of phytoalexin synthesis in soybean. Plant Physiology, v.66, p.1106-1109, 1980.

PARÉ, P.W.; TUMLINSON, J.H. De novo biosynthesis of volatiles induced by insect herbivory in cotton plants. Plant Physiology, v.114, p.1161-1167, 1997.

PARRA, J.R.P. Controle das principais pragas da cana-de-açúcar. IN: CÂMARA, G.M.S.; OLIVEIRA, E.A.M. de (Ed.). Produção de cana-deaçúcar. Piracicaba: FEALQ, 1993. p.184-197.

PASSOS, G.A.S.; NGUYEN, C.; JORDAN, B. Projeto transcriptoma: análise da expressão gênica em larga escala usando DNA-arrays. Biotecnologia Ciência \& Desenvolvimento, v.12, p.34-37, 2000.

PEARCE, G.; STRYDOM, D.; JOHNSON, S. et al. A polypeptide from tomato leaves induces wound-inducible proteinase inhibitor proteins. Science, v.253, p.895-898, 1991.

PEÑA-CORTÉS, H.; PRAT, S.; ATZORN, R. et al. Abscisic acid-deficient plants do not accumulate proteinase inhibitor II following systemin treatment. Planta, v.198, p.447-451, 1996. 
PEÑA-CORTÉS, H.; SÁNCHEZ-SERRANO, J.J.; MERTENS, R. et al. Abscisic acid is involved in the wound-induced expression of the proteinase inhibitor II gene in potato and tomato. Proceedings of the National Academy of Science of the United States of America, v.86, p.9851-9855, 1989.

PEÑA-CORTÉS, H.; WILLMITZER, L.; SÁNCHEZ-SERRANO, J.J. Abscisic acid mediates wound induction but not developmental-specific expression of the proteinase inhibitor II gene family. The Plant Cell, v.3, p.963-972, 1991.

PERNAS, M.; SÁNCHEZ-MONGE, R.; SALCEDO, G. Biotic and abiotic stress can induce cystatin expression in chestnut. Federation of European Biochemical Societies, v.467, p. 206-210, 2000.

PERRET, E.; FERRAN, E.A.; MARINX, O. et al. Improved differential screening approach to analyse transcriptional variations in organized cDNA libraries. Gene, v.208, p.103-115, 1998.

PIÉTU, G.; ALIBERT, O.; GUICHARD, V. et al. Novel gene transcripts preferentially expressed in human muscles revealed by quantitative hybridization of a high density cDNA array. Genome Research, v.6, p.429503, 1996.

POMPERMAYER, P.; LOPES, A.R.; TERRA, W.R. et al. Effects of soybean proteinase inhibitor on development, survival and reproductive potential of the sugarcane borer, Diatraea saccharalis. Entomologia Experimentalis et Applicata, v.99, p.79-85, 2001.

POMPERMAYER, P.; FALCO, M.C.; PARRA, J.R.P. et al. Coupling diet quality and Bowman-Birk and Kunitz-type soybean proteinase inhibitor effectiveness to Diatraea saccharalis development and mortality. Entomologia Experimentalis et Applicata, v.109, p.217-224, 2003.

PRASHER, D.C.; ECKENRODE, V.K.; WARD, W.W. et al. Primary structure of the Aequorea victoria green-fluorescent protein. Gene, v.111, p.229-233, 1992.

PROSSIGA. www.prossiga.br/basededados (20 nov. 2002). 
RACUSEN, D.; FOOTE, M. A major soluble glycoprotein of potato tuber. Journal of Food Biochemistry, v.4, p.43-52, 1980.

RAKWAL, R.; AGRAWAL, G.K.; JWA, N. Characterization of a rice (Oriza sativa L.) bowman-birk proteinase inhibitor: tightly light regulated induction in response to cut, jasmonic acid, ethylene and protein phosphatase $2 \mathrm{~A}$ inhibitors. Gene, v.263, p.189-198, 2001.

REYMOND, P.; FARMER, E.E. Jasmonate and salicylate as global signals for defense gene expression. Current Opinion in Plant Biology, v.1, p.404411, 1998.

REYMOND, P.; WEBER H.; DAMOND, M. et al. Differential gene expression in response to mechanical wounding and insect feeding in Arabidopsis. The Plant Cell, v.12, p.707-719, 2000.

RICKAUER, M.; BOTTIN, A.; ESQUERRE-TUGAYE, M. Regulation of proteinase inhibitor production in tobacco cells by fungal elicitors, hormonal factors and methyl jasmonate. Plant Physiology and Biochemistry, v.30, p.579-584, 1992.

ROACH, B.T. Case for a core collection of sugarcane germplasm. Proceedings of the International Society of Sugar Cane Technologists, v.21, p.339-350, 1995.

ROHRMEIER, T.; LEHLE, L. WIP1, a wound-inducible gene from maize with homology to Bowman-Birk proteinase inhibitors. Plant Molecular Biology, v.22, p.783-792, 1993.

ROJO, E.; TITARENKO, E.; LEON, J. et al. Reversible protein phosphorylation regulates jasmonic acid-dependent and -independent wound signal transduction pathways in Arabidopsis thaliana. The Plant Journal, v.13, p.153-165, 1998.

ROMEIS, T.; PIEDRAS, P.; ZHANG, S. et al. Rapid Avr9- and Cf-9 -dependent activation of MAP kinases in tobacco cell cultures and leaves: convergence of resistance gene, elicitor, wound, and salicylate responses. The Plant Cell, v.11, p.273-287, 1999. 
ROSSATO, L.; MacDUFF, J.H.; LAINÉ, P. et al. Nitrogen storage and remobilization in Brassica napus L. during the growth cycle: effects of methyl jasmonate on nitrate uptake, senescence, growth and VSP accumulation. Journal of Experimental Botany, v.53, p.1131-1141, 2002.

ROY, I.; GUPTA, M.N. Purification of a "double-headed" inhibitor of alphaamylase/proteinase $\mathrm{K}$ from wheat germ by expanded bed chromatography. Bioseparation, v.9, p.239-245, 2000.

RYAN, C.A. Assay and biochemical properties of the proteinase inhibitorinduced factor, a wound hormone. Plant Physiology, v.54, p.328-332, 1974.

RYAN, C.A. Proteinase inhibitor in plants: genes for improving defense against insects and pathogens. Annual Review of Phytopathology, v.28, p.425449, 1990.

RYAN, C.A. The systemin signaling pathway: differential activation of plant defensive genes. Biochimica et Biophysica Acta, v.1477, p.112-121, 2000.

RYAN, C.A.; PEARCE, G. Systemin: a polypeptide signal for plant defensive genes. Annual Review of Cell and Developmental Biology, v.14, p.1-17, 1998.

SALES, M.P.; GERHARDT, I.R.; GROSSI-DE-SÁ, M.F. et al. Do legume storage proteins play a role in defending seeds against bruchids? Plant Physiology, v.124, p.515-522, 2000.

SARAVITZ, D.M.; SIEDOW, J.N. The lipoxygenase isozymes in soybean (Glycine max [L.] Merr.) leaves: changes during leaf development, after wounding, and following reproductive sink removal. Plant Physiology, v.107, p.535-543, 1995.

SARAVITZ, D.M.; SIEDOW, J.N. The differential expression of wound-inducible lipoxygenase genes in soybean leaves. Plant Physiology, v.110, p.287299, 1996.

SARGENT, T.D. Isolation of differentially expressed gene. Methods in Enzymology, v.152, p.423-432, 1987. 
SASAKI, T. The rice genome project in Japan. Proceedings of the National Academy of Science of the United States of America, v.95, p.2027-2028, 1998.

SASAKI, Y.; ASAMIZU, E.; SHIBATA, D. et al. Monitoring of methyl jasmonateresponsive genes in Arabidopsis by cDNA macroarray: self-activation of jasmonic acid biosynthesis and crosstalk with other phytohormone signaling pathways. DNA Research, v.8, p.153-161, 2001.

SCANDALIOS, J.G. Oxygen stress and superoxide dismutases. Plant Physiology, v.101, p.7-12, 1993.

SCHAFFER, R.; LANDGRAF, J.; ACCERBI, M. et al. Microarray analysis of diurnal and circadian-regulated genes in Arabidopsis. The Plant Cell, v.13, p.113-123, 2001.

SCHALLER, A.; RYAN, C.A. Systemin - a polypeptide defense signal in plants. BioEssays, v.18, p.27-33, 1995.

SCHENA, M.; SHALON, D.; DAVIS, R.W. et al. Quantitative monitoring of gene expression patterns with a complementary DNA microarray. Science, v.270, p.467-470, 1995.

SCHENK, P.M.; KAZAN, K.; HELLER, R. et al. Coordinated plant defense responses in Arabidopsis revealed by microarray analysis. Proceedings of the National Academy of Science of the United States of America, v.97, p.11655-11660, 2000.

SCHITTKO, U.; HERMSMEIER, D.; BALDWIN, I.T. Molecular interactions between the specialist herbivore Manduca sexta (Lepidoptera, Sphingidae) and its natural host Nicotiana attenuata. II. Accumulation of plant mRNAs in response to insect-derived cues. Plant Physiology, v.125, p.701-710, 2001.

SCHUMMER, M.; NG, W.V.; BUMGARNER, R.E. et al. Comparative hybridization of an array of 21,500 ovarian cDNAs for the discovery of genes overexpressed in ovarian carcinomas. Gene, v.238, p.375-385, 1999. 
SCHWEIZER, P.; BUCHALA, A.; METRAUX, J. Gene-expression patterns and levels of jasmonic acid in rice treated with the resistance inducer 2,6dichloroisonicotinic acid. Plant Physiology, v.115, p.61-70, 1997.

SCOTT, J.G.; WEN, Z.M. Cytochromes P450 of insects: the tip of the iceberg. Pest Management Science, v.57, p.958-967, 2001.

SCREENIVASAN, T.V.; AHLOOWALIA, B.S.; HEINZ, D.J. Cytogenetics. IN: HEINZ, D.J. (Ed.). Sugarcane improvement trough breeding. Amsterdam: Elsevier Press, 1987. p.211-253.

SEKI, M.; ISHIDA, J.; NARUSAKA, M. et al. Monitoring the expression pattern of around 7,000 Arabidopsis genes under ABA treatments using a full-length cDNA microarray. Functional \& Integrative Genomics, v.2, p.282-291, 2002.

SEKI, M.; NARUSAKA, M.; ABE, $\mathrm{H}$. et al. Monitoring the expression pattern of 1,300 Arabidopsis genes under drought and cold stress by using a full-length cDNA microarray. The Plant Cell, v.13, p.61-72, 2001.

SEMBDNER, G.; PARTHIER, B. The biochemistry and the physiologicaland molecular actions of jasmonates. Annual Review of Plant Physiology and Plant Molecular Biology, v.44, p.569-589, 1993.

SEO, S.; SANO, H.; OHASHI, Y. Jasmonate-based wound signal transduction requires activation of wipk, a tobacco mitogen-activated protein kinase. The Plant Cell, v.11, p.289-298, 1999.

SGRILLO, R.B. Desenvolvimento de modelo matemático para população da broca da cana-de-açúcar, Diatraea saccharalis (Fabr., 1794) e simulação da técnica do indivíduo estéril. Piracicaba, 1979. 189p. Tese (Doutorado) Escola Superior de Agricultura "Luiz de Queiroz", Universidade de São Paulo.

SHARMA, H.C.; NORRIS, D.M. Chemical basis of resistance in soyabean to cabbage looper, Trichoplusia ni. Journal of Science of Food and Agriculture, v.55, p.353-364, 1991. 
SILVA, C.P.; TERRA, W.R.; GROSSI-DE-SÁ, M.F. et al. Induction of digestive $\alpha$-amylases in larvae of Zabrotes subfasciatus (Coleoptera: Bruchidae) in response to ingestion of common bean $\alpha$-amylase inhibitor 1 . Journal of Insect Physiology, v.47, n.11, p.1283-1290, 2001.

SITBON, F.; PERROT-RECHENMANN, C. Expression of auxin-regulated genes. Physiologia Plantarum, v.100, p.443-455, 1997.

SOMERVILLE, C.,;BROWSE, J.; JAWORSKI, J.G. et al. Lipids. IN: BUCHANAN, B.; GRUISSEM, W.; JONES, R. (Ed.). Biochemistry \& Molecular Biology of Plants. Rockville: American Society of Plant Physiologists, 2000. p.456-527.

SOMMER, A.; NE'EMAN, E.; STEFFENS, J.C. et al. Importing, targeting, and processing of a plant polyphenol oxidase. Plant Physiology, v.105, p.13011311, 1994.

STASWICK, P.E. Storage proteins of vegetative plant tissues. Annual Review of Plant Physiology and Plant Molecular Biology, v.45, p.303-322, 1994.

STOHL, L.L.; LAMBOWITZ, A.M. A colony filter-hybridization procedure for the filamentous fungus Neurospora crassa. Analytical Biochemistry, v.134, p.82-85, 1983.

STOUT, M.J.; FIDANTSEF, A.L.; DUFFEY, S.S. et al. Signal interactions in pathogen and insect attack: systemic plant mediated interactions between pathogens and herbivores of the tomato, Licopersum esculentum. Physiological and Molecular Plant Pathology, v.54, p.115-130, 1999.

STRATMANN, J.W.; RYAN, C.A. Myelin basic protein kinase activity in tomato leaves is induced systemically by wounding and increases in response to systemin and oligosaccharidae elicitors. Proceedings of the National Academy of Science of the United States of America, v.94, p.1108511089, 1997.

STRAUSS, S.Y.; AGRAWAL, A.A. The ecology and evolution of plant tolerance to herbivory. Trends in Ecology and Evolution, v.14, p.79-185, 1999. 
STRICKLAND, J.A.; ORR, G.L.; WALSH, T.A. Inhibition of diabrotica larval growth by patatin, the lipid acyl hydrolase from potato tubers. Plant Physiology, v.109, p.667-674, 1995.

STUPIELLO, J.P. A cana-de-açúcar como matéria prima. IN: PARANHOS, S.B. (Coord.). Cana-de-açúcar: cultivo e utilização. Campinas: Fundação Cargill, 1987. v.2, p.187-259.

TANAKA, A.S.; SAMPAIO, M.U.; MENTELE, R. et al. Sequence of a new Bowman-Birk inhibitor from Torresea acreana seeds and comparison with Torresea cearensis trypsin inhibitor (TcTI2). Journal of Protein Chemistry, v.15, n.6, p.553-560, 1996.

TANAKA, T.S.; JARADAT, S.A.; LIM, M.K. et al. Genome-wide expression profiling of mid-gestation placenta and embryo using a 15,000 mouse developmental cDNA microarray. Proceedings of the National Academy of Science of the United States of America, v.97, p.9127-9132, 2000.

TELLES, G.P.; DaSILVA, F.R. Trimming and clustering sugarcane ESTs. Genetics and Molecular Biology, v.24, p.17-23, 2001.

TERÁN, F.O. Pragas da cana-de-açúcar. IN: PARANHOS, S.B. (Coord.) Cana-de-açúcar: cultivo e utilização. Campinas: Fundação Cargil, 1987. v.2, p.605-628.

TERÁN, F.O.; SANCHEZ, A.G.; PRECETTI, A.A.C.M. Estudos sobre resistência da cana à broca em telado. Primeiros resultados. Piracicaba: Centro de Tecnologia Copersucar, 1985. p.2-11. Boletim Técnico 29.

TERRA, W.R.; FERREIRA, C. Insect digestive enzymes - properties, compartmentalization and function. Comparative Biochemistry and Physiology. B, Comparative Biochemistry, v.109, p.1-62, 1994.

THALER, J.S.; STOUT, M.J.; KARBAN, R. et al. Exogenous jasmonates simulate insect wounding in tomato plants (Lycopersicon esculentum) in the laboratory and field. Journal of Chemical Ecology, v.22, p.1767-1781, 1996. 
THIMM, O.; ESSIGMANN, B.; KLOSKA, S. et al. Response of Arabidopsis to iron deficiency stress as revealed by microarray analysis. Plant Physiology, v.127, p.1030-1043, 2001.

TIFFIN, P.; GAUT, B.S. Molecular evolution of the wound-induced serine proteinase inhibitor wip1 in zea and related genera. Molecular Biology and Evolution, v.18, n.11, p.2092-2101, 2001.

TRESE, A.T.; PUEPPKE, S.G. Cloning of cowpea (Vigna unguiculata) genes that are regulated during initiation of nodulation. Molecular Plant-Microbe Interactions, v.4, p.46-51, 1991.

TURLING, T.C.J.; TUMLINSON, J.K.; LEWIS, W.J. Exploration of herbivoreinduced plant odors by host-seeking parasitic wasps. Science, v.250, p.1251-1253, 1990.

TURNER, J.G.; ELLIS, C.; DEVOTO, A. The jasmonate signal pathway. The Plant Cell, v.14, S153-S164, 2002.

USINAS E DESTILARIAS DO OESTE PAULISTA - UDOP. Copersucar comercializa 17 variedades de cana. Agência UDOP de notícias. www.nuca.ie.ufrj.br/infosucro/arquivos/boletin020.htm\#3_2 (13 nov. 2001).

UTSUGI, S.; SAKAMOTO, W.; MURATA, M. et al. Arabidopsis thaliana vegetative storage protein (VSP) genes: gene organization and tissuespecific expression. Plant Molecular Biology, v.38, p.565-576, 1998.

VAN DE WIEL, C.; NORRIS, J.H.; BOCHENEK, B. et al. Nodulin gene expression and ENOD2 localization in effective, nitrogen-fixing and ineffective, bacteria-free nodules of alfalfa. The Plant Cell, v.2, p.10091017, 1990.

VANDENBOSCH, K.A.; RODGERS, L.R.; SHERRIER, D. et al. A peanut nodule lectin in infected cells and in vacuoles and the extracellular matrix of nodule parenchyma. Plant Physiology, v.104, p.327-337, 1994.

VANHAL, N.L.; VORST, O.; VANHOUWELINGEN, A.M. et al. The application of DNA microarrays in gene expression analysis. Journal of Biotechnology, v.78, p.271-280, 2000. 
VELCULESCU, V.E.; ZHANG, L.; VOLGENSTEIN, B. et al. Serial analysis of gene-expression. Science, v.270, p.484-487, 1995.

VENDRAMIN, J.D. Técnicas para avaliação da infestação de Diatraea saccharalis (Fabr., 1794, Lepidoptera: Pyralidae) em cultivares de cana-deaçúcar, com base no complexo broca-podridões. Piracicaba, 1987. 156p. Tese (Livre-Docência) - Escola Superior de Agricultura "Luiz de Queiroz", Universidade de São Paulo.

VENDRAMIM, J.D.; SILVA, F.C.; CAMARGO, A.P. Avaliação das dimensões da região danificada pelo complexo broca-podridões em seis cultivares de cana-de-açúcar. Separata de Anais da Sociedade Entomológica do Brasil, v.18, p.105-118, 1989.

VETTORE, A.L.; SILVA, F.R.; KEMPER, E.L. et al. The libraries that made SUCEST. Genetics and Molecular Biology, v.24, p.1-7, 2001.

VETTORE, A.L.; SILVA, F.R.; KEMPER, E.L. et al. Analysis and functional annotation of an expressed sequence tag collection for tropical crop sugarcane. Genome Research, v.13, p.2725-2735, 2003.

VICK, B.A.; ZIMMERMANN, D.C. Biosynthesis of jasmonic acid by several plant species. Plant Physiology, v.75, p.458-461, 1984.

VLIEGHE, K.; VUYLSTEKE, M.; FLORQUIN, K. et al. Microarray analysis of E2Fa-DPa-overexpressing plants uncovers a cross-talking genetic network between DNA replication and nitrogen assimilation. Journal of Cell Science, v.116, p.4249-4259, 2003.

WAN, J.S.; SHARP, S.J.; POIRIER, G.M.C. et al. Cloning differentially expressed mRNAs. Nature Biotechnology, v.14, p.1685-1691, 1996.

WANG, J.; SHEEHAN, M.; BROOKMAN, H. et al. Characterization of cDNAs differentially expressed in roots of tobacco (Nicotiana tabacum cv Burley 21) during the early stages of alkaloid biosynthesis. Plant Science, v.158, p.1932, 2000. 
WANG, R.; GUEGLER, K.; LaBRIE, S.T. et al. Genomic analysis of a nutrient response in Arabidopsis reveals diverse expression patterns and novel metabolic and potential regulatory genes induced by nitrate. The Plant Cell, v.12, p.1491-1509, 2000.

WANG, X.R.; DING, X.F.; GOPALAKRISHNAN, B. et al. Characterization of a $46 \mathrm{kDa}$ insect chitinase from transgenic tobacco. Insect Biochemistry and Molecular Biology, v.26, p.1055-1064, 1996.

WANG, Y.H.; GARVIN, D.F.; KOCHIAN, L.V. Nitrate-induced genes in tomato roots. Array analysis reveals novel genes that may play a role in nitrogen nutrition. Plant Physiology, v.127, p.345-359, 2001.

WASTERNACK, C.; ATZORN, R.; PEÑA-CORTÉS, H. et al. Alteration of gene expression by jasmonate and $A B A$ in tobacco and tomato. Journal of Plant Physiology, v.147, p.503-510, 1996.

WASTERNACK, C.; PARTHIER, B. Jasmonate-signaled plant gene expression. Trends in Plant Science, v.2, p.302-307, 1997.

WATAKABE, A.; SUGAI, T.; NAKAYA, N. et al. Similarity and variation in gene expression among human cerebral cortical subregions revealed by DNA macroarrays: technical consideration of RNA expression profiling from postmortem simples. Molecular Brain Research, v.88, p.74-82, 2001.

WHITE, K.P.; RIFKIN, S.A.; HURBAN, P. et al. Microarray analysis of Drosophila development during metamorphosis. Science, v.286, p.21792184, 1999.

WHITE, W.H. Movement and establishment of sugarcane borer (Lepidoptera: Pyralidae) larvae on resistant and susceptible sugarcane. Florida Entomologist, v.76, n.3, p.465-473, 1993.

WITTENBACH, V.A. Purification and characterization of a soybean leaf storage glycoprotein. Plant Physiology, v.73, p.125-129, 1983.

XIONG, L.; LEE, M.; QI, M. et al. Identification of defense-related rice genes by suppression subtractive hybridization and differential screening. Molecular Plant-Microbe Interactions, v.14, p.685-692, 2001. 
YANG, K.Y.; LIU, Y.; ZHANG, S. Activation of a mitogen-activated protein kinase pathway is involved in disease resistance in tobacco. Proceedings of the National Academy of Science of the United States of America, v.98, p.741-746, 2001.

YENCHO, G.C.; COHEN, M.B.; BYRNE, P.F. Applications of tagging and mapping insect resistance loci in plants. Annual Review of Entomology, v.45, p.393-422, 2000.

YOO, J.H.; CHEONG, M.S.; PARK, C.Y. et al. Regulation of the dual specificity protein phosphatase, DSPTP1, through interactions with calmodulin. The Journal of Biological Chemistry, v.279, p.848-858, 2004.

ZANGERL, A.R. Furanocoumarin induction in wild parsnip: evidence for an induced defense against herbivores. Ecology, v.71, n.5, p.1926-1932, 1990.

ZHANG, S.; AND KLESSIG, D.F. Resistance gene N-mediated de novo synthesis and activation of a tobacco mitogen-activated protein kinase by tobacco mosaic virus infection. Proceedings of the National Academy of Science of the United States of America, v.95, p.7433-7438, 1998.

ZHAO, N.; HASHIDA, H.; TAKAHASHI, N. et al. High-density cDNA filter analysis: a novel approach for large-scale, quantitative analysis of gene expression. Gene, v.156, p.207-213, 1995. 
APÊNDICES 


\section{APÊNDICE 1 - Solução OLB}

*Solução OLB = Solução A + Solução B + Solução C = $1: 2,5: 1,5$

- Solução A

$1 \mathrm{ml}$ de Solução O

1,8\% (v/v) de 2-mercaptoetanol

1,5\% (v/v) de mix d(ATG)TP (100mM)

- Solução B

2M HEPES-NaOH pH 6,6

- Solução C

$3 \mathrm{mM}$ Tris- $\mathrm{HCl} \mathrm{pH} \mathrm{7,4}$

0,2mM EDTA

- Solução O

1.25M Tris- $\mathrm{HCl} \mathrm{pH} \mathrm{8,0}$

$125 \mathrm{mM} \mathrm{MgCl} 2$ 


\section{APÊNDICE 2 - Programação para Análise da Otimização da Técnica}

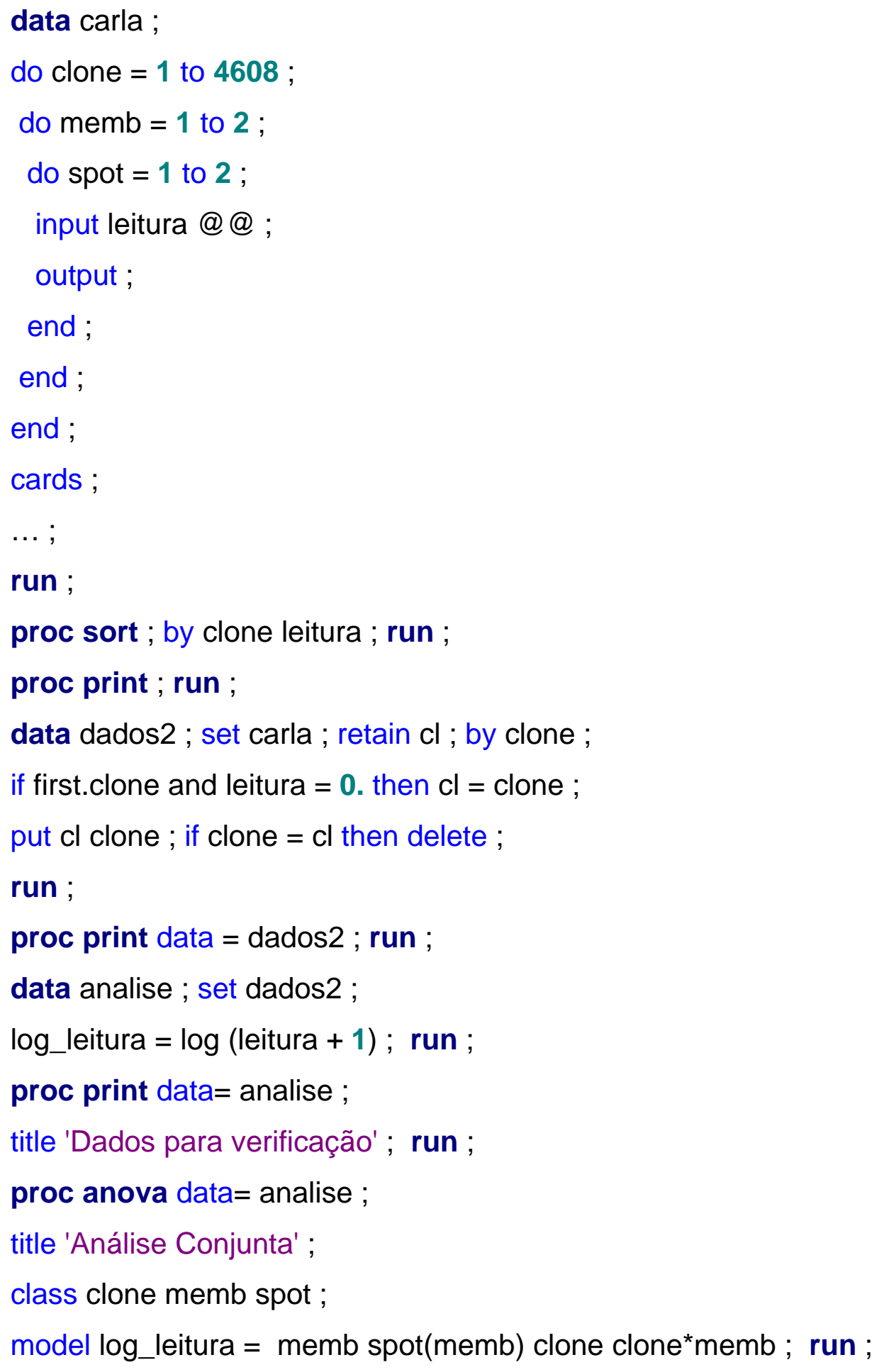




\section{APÊNDICE 3 - Programação para Normalização com a Sonda Overgo}

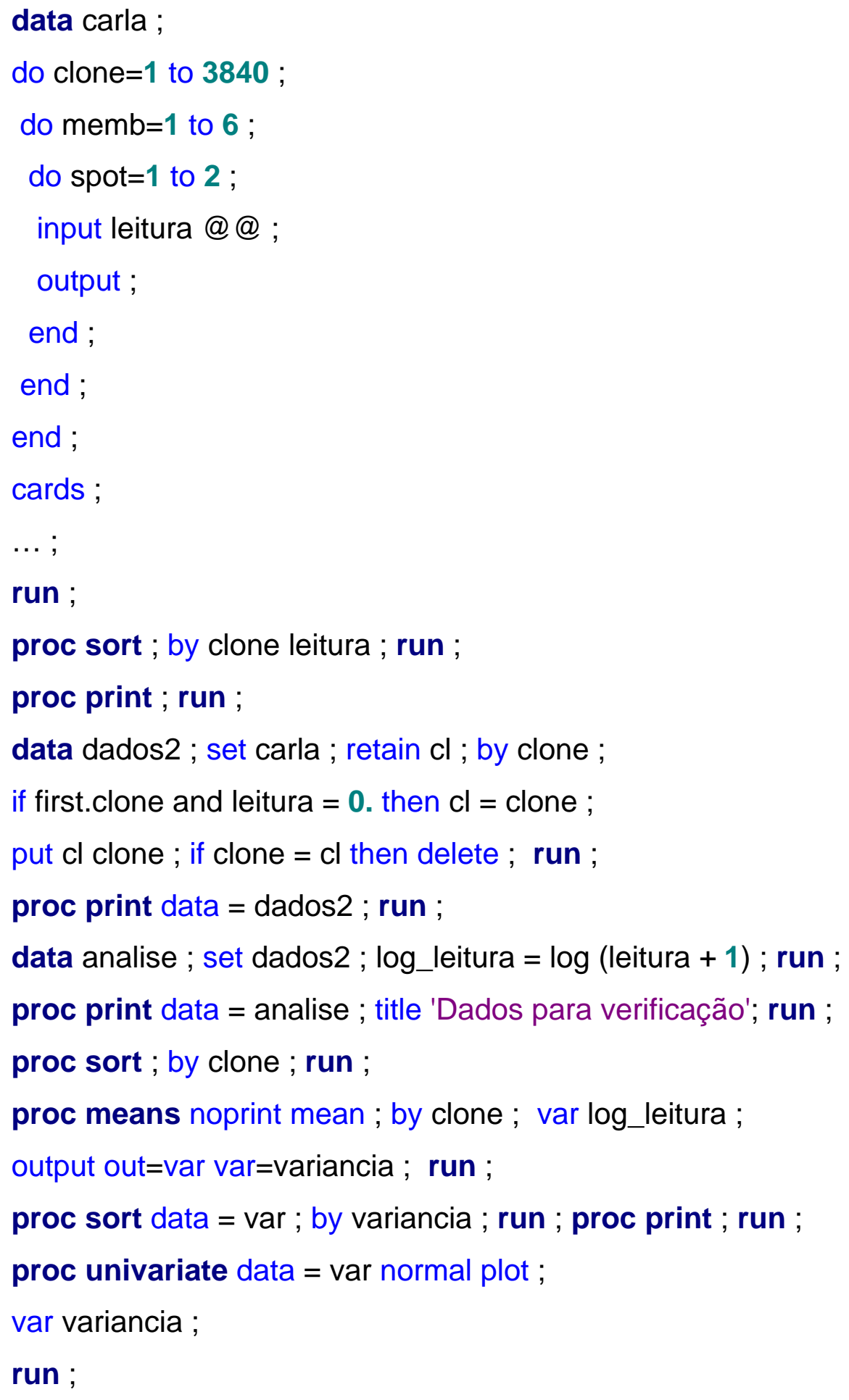




\section{APÊNDICE 4 - Programação para Normalização com a Sonda de cDNA}

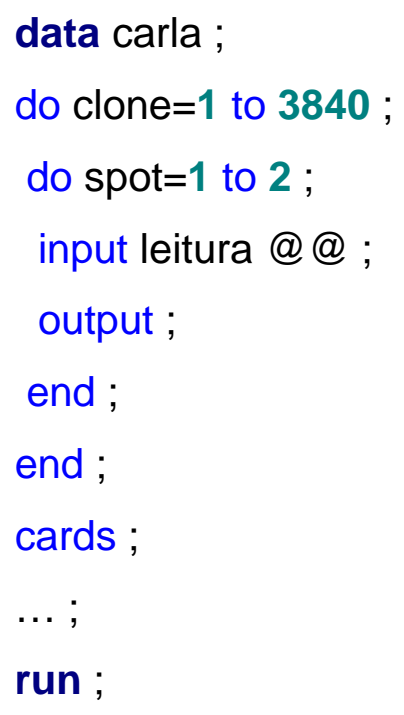




\section{APÊNDICE 5 - Clones Selecionados da Variedade Susceptível (SP80-3280) com Indução em Apenas um Tempo}

\begin{tabular}{|c|c|}
\hline $\begin{array}{l}30 \text { minutos } \\
\text { CLONES SELECIONADOS }\end{array}$ & DESCRIÇÃO \\
\hline SCACAD1038A11 & AtB'gamma - like protein \\
\hline SCACLR1126G09 & ND \\
\hline SCACLR1128C10 & ND \\
\hline SCACLR1129F12 & F1N21.12 \\
\hline SCACLR1132A07 & ND \\
\hline SCACLR2007E11 & ND \\
\hline SCACLR2022A12 & receptor-like protein kinase 1 \\
\hline SCAGLR2018H08 & ND \\
\hline SCAGLR2026G02 & ND \\
\hline SCBGLR1095H05 & ND \\
\hline SCBGLR1097H10 & ND \\
\hline SCBGLR1100D12 & ND \\
\hline SCBGLR1119B11 & THA4 \\
\hline SCBGRT1053H02 & lipoxygenase \\
\hline SCBGST3103A02 & ND \\
\hline SCBGST3107G04 & shoot meristemless \\
\hline SCBGST3111B08 & ND \\
\hline SCCCCL4015B02 & putative glutathione S-transferase OsGSTU4 \\
\hline SCCCFL3001G02 & jacalin homolog \\
\hline SCCCLR1C09D05 & ND \\
\hline SCCCLR2001G10 & ND \\
\hline SCCCLR2004C05 & ND \\
\hline SCCCLR2C01B10 & ND \\
\hline SCCCST1C06D01 & S-receptor kinase \\
\hline SCCCST3083H05 & ND \\
\hline SCEPRZ1011G10 & putative cinnamyl-alcohol dehydrogenase \\
\hline SCEQLR1091G01 & cotton fiber expressed protein 1 \\
\hline SCEQLR1092A01 & auxin-binding protein 4 precursor \\
\hline SCEZHR1086B06 & whitefly-induced gp91-phox \\
\hline SCEZLR1031F04 & G-box binding factor 1 \\
\hline SCEZLR1031G08 & lipid-transfer protein precursor \\
\hline SCEZRT2020A03 & chaperonin; similar to GroEL protein \\
\hline SCJFAD1010F07 & Myb factor protein [Oryza sativa]" \\
\hline SCJFAD1012A08 & auxin responsive transcription factor \\
\hline SCJFST1047C06 & probable carboxyl-terminal proteinase \\
\hline SCJFST1047D08 & D-ribulose-5-phosphate 3-epimerase \\
\hline
\end{tabular}


SCJFST1047H12

SCJFST1048H08

SCJLLR1103G06

SCJLLR1106E04

SCJLLR1107G06

SCJLLR1108A10

SCJLLR1108C11

SCJLLR2006G06

SCJLLR2006G12

SCJLRT1015B03

SCJLRT1020E06

SCMCLR1123B02

SCMCLR1125H05

SCMCST1049C07

SCMCST1053D08

SCMCST1058D11

SCQGSB1083E01

SCQGST3124G07

SCQGST3125C08

SCQSFL3034B10

SCQSRT2033F06

SCQSST3114B03

SCQSST3115B02

SCQSST3115B12

SCQSST3116B02

SCRFST1041C03

SCRFST1044B09

SCRFST1045B03

SCRLAM1007D07

SCRLLR1111H07

SCSBST3095E05

SCSBST3098E09

SCSBST3100G06

SCSFST1064G07

SCSFST1064H01

SCSFST1065B06

SCSFST1066F08

SCSFST3076C11

SCSFST3078B04

SCSGAD1009F02

SCSGLV1005D02

SCSGLV1007H04

SCSGLV1009D03

SCSGLV1009D06

SCSGLV1013A05 wound-induced GSK-3-like protein

flavonol 3-O-glucosyltransferase-like protein

ND

ND

ND

ND

putative U2 snRNP auxiliary factor

ND

Ykl160wp

chitinase III C10150

dihydrokaempferol 4-reductase A

ND

similar to wak1 gene (AJ009696)

ND

putative protein

similar to acyl-CoA dehydrogenases

phenylalanine ammonia-lyase

ND

amidase

isoflavone reductase homolog irl

putative flavonoid 3'-hydroxylase

ND

protein kinase-like protein

ND

ND T24P15.19

ND F15J5.30

Contains similarity to MLL protein

ND

F23N19.10

ND

ND

$\mathrm{C} 2 \mathrm{H} 2$-type zinc finger protein, putative chlorophyll $\mathrm{a}-\mathrm{b}$ binding protein $\mathrm{m} 9$ precursor ND

ND

similar to putative reverse transcriptase

putative ubiquitin protein

dihydrolipoamide dehydrogenase precursor

ND

cyclophylin-like protein

ND

ferredoxin I precursor

ND

ND

endochitinase A2 precursor 
SCSGRZ3063E01

SCSGST1072H02

SCUTLR1037C05

SCUTLR2008F03

SCUTST3086D02

SCUTST3086E08

SCUTST3091G03

SCUTST3127A02

SCUTST3127E12

SCUTST3128F07

SCUTST3129E03

SCUTST3130D10

SCUTST3131G03

SCVPLR2012B05

SCVPLR2012E12

SCVPLR2027C11

SCVPRT2081C04

SCVPRZ3025F04

SCVPST1059F07

SCVPST1060B02

SCVPST1061F10

SCVPST1063H10 arginine decarboxylase

probable serine/threonine-specific protein kinase putative oxalate oxidase (germin protein)

ND

$\mathrm{ND}$

ND

ND

ND

ND

ND F16J13.30

calcium-dependent protein kinase 9

disease resistance protein RPM1 homolog

lipid transfer protein

$\mathrm{ND}$

cotton fiber expressed protein 1

ND

lactoylglutathione lyase

uncoupling protein mitochonrial

ND F3A4.70

$\mathrm{ND}$

putative WD40-repeat protein

ND

\begin{tabular}{cl}
\hline \multicolumn{1}{c}{6 horas } & \\
CLONES SELECIONADOS & \multicolumn{1}{c}{ DESCRIÇÃO } \\
\hline SCACLR1132D05 & histone H3 \\
SCACLR1132F08 & ND \\
SCAGLR2011B04 & 60S ribosomal protein L18 \\
SCAGLR2011C02 & fructokinase \\
SCBFSD2035E07 & thaumatin-like protein \\
SCBGLR1095H08 & ND \\
SCBGLR1097G08 & chloroplast thylakoidal processing peptidase \\
SCBGLR1100A04 & ND \\
SCBGLR1100F12 & ND \\
SCBGLR1112H05 & ND \\
SCBGLR1113A07 & ND \\
SCBGLR1119D12 & ND \\
SCBGLR1120C03 & ND \\
SCBGST3104C11 & ND \\
SCBGST3105A03 & ND \\
SCBGST3108B10 & MtN3 \\
SCBGST3108E12 & myb-related transcription factor \\
SCBGST3111B04 & ND \\
SCCCAD1004H02 & catalase (EC 1.11.1.6) 3 \\
&
\end{tabular}




\begin{tabular}{|c|c|}
\hline SCCCLR1C01B12 & ND \\
\hline SCCCLR1C01G12 & PPR-repeat protein, putative \\
\hline SCCCLR1C04A01 & putative homeodomain protein \\
\hline SCCCLR1C09C11 & ND \\
\hline SCCCLR2001C02 & Regulator of condensation-like protein \\
\hline SCCCLR2002E03 & ND \\
\hline SCCCLR2004C09 & ND \\
\hline SCCCLR2C01E07 & ND \\
\hline SCCCLR2C02A01 & putative wound-induced protein \\
\hline SCCCLR2C02D06 & ND \\
\hline SCCCLV1001F07 & putative Tub family protein \\
\hline SCCCLV1001G08 & ND \\
\hline SCCCST1C02D08 & putative receptor ser/thr protein kinase \\
\hline SCCCST3002D02 & MLA6 protein \\
\hline SCCCST3002G01 & ND \\
\hline SCCCST3006B02 & dnaJ protein homolog T9A4.1 \\
\hline SCEPCL6025G08 & alpha-amylase/subtilisin inhibitor \\
\hline SCEQLR1092D01 & ND \\
\hline SCEQLR1094C08 & high mobility group I/Y-2 \\
\hline SCJFAD1012F11 & LRK1 protein [Oryza sativa]" \\
\hline SCJFAD1013H07 & transport inhibitor response 1 (TIR1) \\
\hline SCJFLR2035E12 & Similar to Transposon MAGGY gag \\
\hline SCJFLR2036C03 & ND \\
\hline SCJFST1047C03 & protein phosphatase $2 A$ regulatory subunit B' \\
\hline SCJLLB2076C12 & endochitinase $\mathrm{A} 2$ precursor \\
\hline SCJLLR1102A03 & ND \\
\hline SCJLLR1102G03 & ND \\
\hline SCJLLR1104C09 & ND \\
\hline SCJLLR1105A01 & histone H2A.4 \\
\hline SCJLLR1106A11 & ND \\
\hline SCJLLR2013C01 & ND \\
\hline SCMCLR1124C06 & ND \\
\hline SCMCLR1125A03 & ND \\
\hline SCMCLR1125A10 & mitochondrial solute carrier protein homolog \\
\hline SCMCST1050F09 & late embryogenesis-like protein \\
\hline SCMCST1051A10 & ND \\
\hline SCMCST1052H11 & ND \\
\hline SCMCST1058D07 & palate associated transmembrane protein-like \\
\hline SCMCST1058H08 & ND \\
\hline SCQGHR1012F03 & polygalacturonase inhibitor \\
\hline SCQGGLR2010D05 & ND \\
\hline SCQGRT1041A06 & pathogenesis-related protein \\
\hline SCQGST3124E04 & DnaJ protein-like \\
\hline SCQGST3126E09 & ND \\
\hline SCQSLR1089F10 & ND \\
\hline
\end{tabular}




\begin{tabular}{|c|c|}
\hline SCQSRT3054H12 & probable germin protein 4 \\
\hline SCQSST1040F12 & ND \\
\hline SCQSST3113D04 & ND \\
\hline SCRFLR2021A07 & ND T23J7.160 \\
\hline SCRFLR2038A02 & HOMODA hydrolase \\
\hline SCRFLR2038C11 & Iysophospholipase-like protein \\
\hline SCRFST1041A02 & ND \\
\hline SCRFST1041G03 & ND \\
\hline SCRFST1045F01 & axi 1-like protein \\
\hline SCRFST1046B08 & eukaryotic initiation factor f subunit p82-34 \\
\hline SCRLLR1111A01 & ND \\
\hline SCRLLR1111C05 & ND T8P19.40 \\
\hline SCSBRT3039E08 & chitinase III C10501 \\
\hline SCSBST3093A05 & ND \\
\hline SCSBST3098C11 & Oxalyl-CoA decarboxylase \\
\hline SCSFLR2009E05 & GDSL-motif lipase/hydrolase-like protein \\
\hline SCSFST1066C11 & ND \\
\hline SCSFST1066G03 & ND \\
\hline SCSFST3074C01 & peroxidase \\
\hline SCSFST3075A09 & probable omega-3 fatty acid desaturase \\
\hline SCSFST3077C10 & putative chromosome associated protein \\
\hline SCSFST3078G01 & ND \\
\hline SCSFST3080G06 & ND \\
\hline SCSFST3081F05 & ND \\
\hline SCSFST3082E05 & ND \\
\hline SCSGAD1009A05 & putative receptor-like protein kinase \\
\hline SCSGHR1072F02 & peroxidase 4 precursor \\
\hline SCSGLV1006H02 & ND \\
\hline SCSGLV1007D05 & ND \\
\hline SCSGLV1008A09 & ND \\
\hline SCSGLV1009F07 & ND \\
\hline SCSGLV1011H11 & ND \\
\hline SCSGST1069H12 & ND \\
\hline SCSGST1072C04 & ND \\
\hline SCSGST3117C09 & knotted class 1 homeodomain protein liguleless3 \\
\hline SCSGST3118E11 & P-glycoprotein \\
\hline SCSGST3119F06 & ND \\
\hline SCSGST3121A01 & ND \\
\hline SCUTAD1031C08 & heat shock protein 90 \\
\hline SCUTST3087C04 & ND \\
\hline SCUTST3091F02 & ND \\
\hline SCUTST3127F11 & ND \\
\hline SCVPLR2012H01 & ND \\
\hline SCVPST1062F03 & ND \\
\hline
\end{tabular}




\begin{tabular}{ll}
\hline \multicolumn{1}{c}{ 12 horas } & \\
CLONES SELECIONADOS & \\
\hline SCACLR1128A03 & ND \\
SCACLR1132A02 & ND \\
SCACLR2007B03 & beta-galactosidase \\
SCAGLR2018G12 & ND \\
SCAGLR2033C10 & ND \\
SCBGLR1096A06 & weak similarity to a farnesylated protein \\
SCBGLR1100A08 & ND \\
SCBGLR1113E08 & ND \\
SCBGLR1113G08 & bZIP protein \\
SCBGLR1117A09 & ND \\
SCBGLR1118F03 & ND \\
SCBGRT1049B06 & Barwin, Basic Barley Seed Protein \\
SCBGST3103A03 & ND \\
SCBGST3108F09 & ND \\
SCBGST3111C07 & ND \\
SCBGST112A09 & ND \\
SCCCLR1C06B11 & ND \\
SCCCLR2001B05 & ND \\
SCCCLR2002A06 & ND \\
SCCCLR2003G05 & ND \\
SCCCLR2C02F09 & ND \\
SCCCLR2C03D02 & ND \\
SCCCST1C06E09 & ND \\
SCCCST3003E01 & ND \\
SCEPAM1053E12 & ferritin 1 precursor \\
SCEPSD2070C10 & aldose reductase \\
SCEQLR1092E10 & ND \\
SCEQLR1093E02 & ND \\
SCEZAD1078B05 & abrin-a \\
SCJFLR2036F11 & ND \\
SCJFST1047C11 & peptide chain release factor 1 \\
SCJLLR1102G08 & ND \\
SCJLLR1103E11 & ND \\
SCJLLR1108C05 & ATPase \\
SCJLLR2006G03 & ND \\
SCJLLR2028B07 & ND \\
SCJLLR2028F08 & ND \\
SCMCLR1122B12 & ND \\
SCMCLR1124B01 & ND \\
SCMCST1049A08 & ND \\
SCMCST1052E12 & ND \\
SCMCST1052G03 & ND \\
&
\end{tabular}




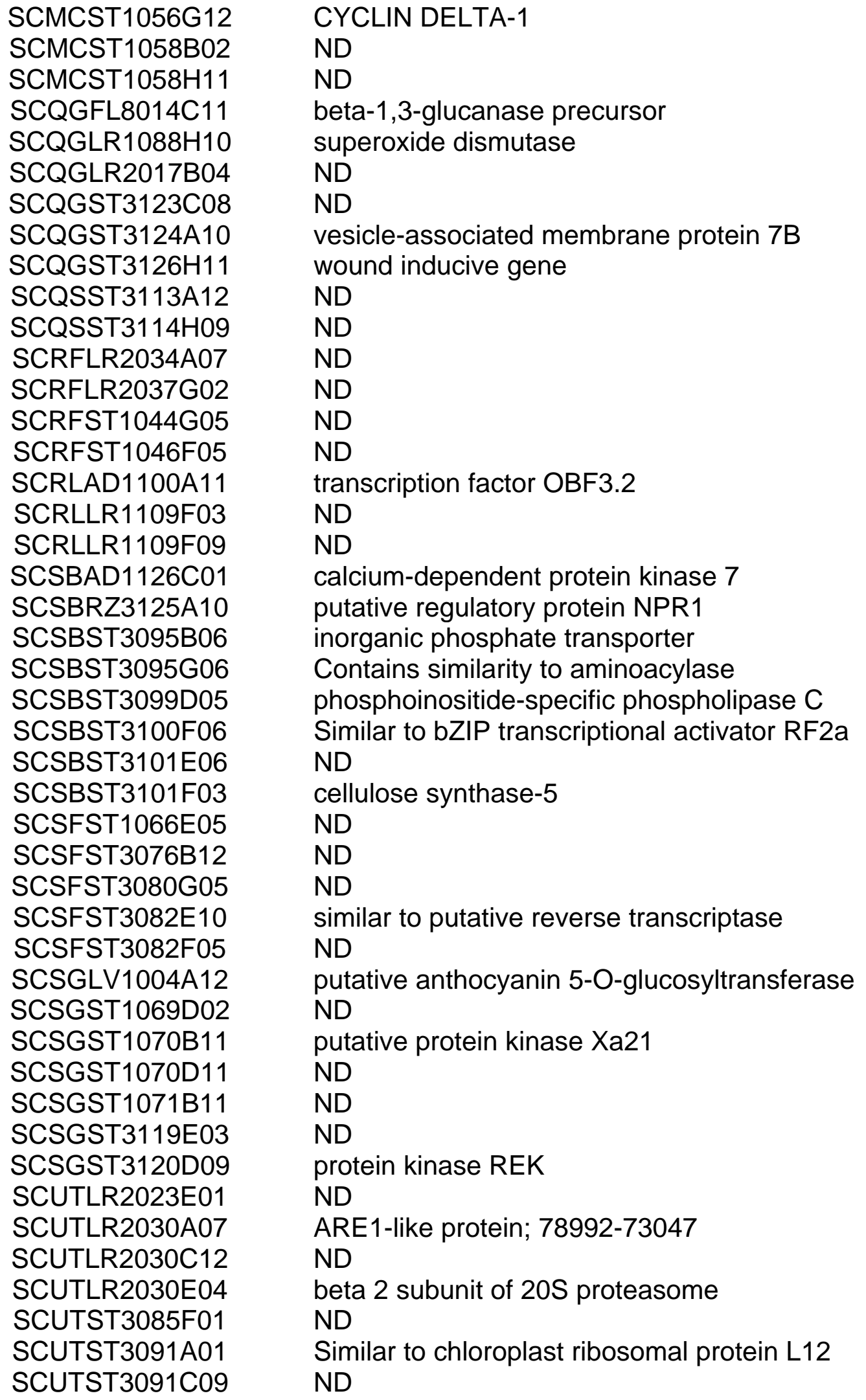




\begin{tabular}{|c|c|}
\hline $\begin{array}{l}\text { SCVPLR2019F01 } \\
\text { SCVPST1059A06 } \\
\text { SCVPST1060H02 } \\
\text { SCVPST1063E05 } \\
\text { SCVPST1063F02 }\end{array}$ & $\begin{array}{l}\text { Similar to } 60 S \text { ribosomal protein L11A } \\
\text { ND } \\
\text { ND } \\
\text { ND } \\
\text { ND }\end{array}$ \\
\hline $\begin{array}{c}24 \text { horas } \\
\text { CLONES SELECIONADOS }\end{array}$ & DESCRIÇÃO \\
\hline SCACLR1128C02 & ND \\
\hline SCACLR1129D02 & ND \\
\hline SCACLR1132D07 & ND \\
\hline SCACLR1132H04 & ND \\
\hline SCACLR2007A07 & ND \\
\hline SCACLR2029D02 & ND \\
\hline SCAGLR2018F12 & peptide methionine sulfoxide reductase \\
\hline SCBFST3132A08 & SINA1 protein \\
\hline SCBGLR1113D01 & ND \\
\hline SCBGLR1118C02 & ND \\
\hline SCBGST3105A02 & ND \\
\hline SCCCLR1121D03 & ND \\
\hline SCCCLR2002D11 & ND \\
\hline SCCCST3001F05 & ND \\
\hline SCCCST3006H06 & acyl-coa-binding protein homolog \\
\hline SCCCST3083A12 & ND \\
\hline SCEQLR1093E12 & Similar to arabinogalactan-like protein (U09556) \\
\hline SCEQLR1094F02 & 40S ribosomal protein S12 \\
\hline SCJFRZ3C05G02 & allene oxide synthase \\
\hline SCJFST1047D01 & ND \\
\hline SCJFST1047G12 & shaggy-related protein kinase theta \\
\hline SCJFST1048H01 & ND \\
\hline SCJLLR1105G05 & alpha-expansin OsEXP7 \\
\hline SCJLLR1106E05 & ND \\
\hline SCJLLR1107E12 & nucleoid DNA-binding protein cnd41-like protein \\
\hline SCJLLR1107F04 & ND \\
\hline SCJLLR2006C07 & ND \\
\hline SCJLLR2013G07 & ND \\
\hline SCMCST1050E10 & putative gag/pol polyprotein \\
\hline SCMCST1051F11 & ND \\
\hline SCMCST1055B01 & ND \\
\hline SCMCST1056F08 & glycyl-trna synthetase \\
\hline SCQGLB2042B04 & SP8 binding protein homolog \\
\hline SCQGLR1087G09 & putative chloroplast prephenate dehydratase \\
\hline SCQGLR2032D03 & ND \\
\hline SCQSSST3116C10 & ND \\
\hline
\end{tabular}


SCQSST3116H05

SCRFLR2038B09

SCRFST1041D04

SCRFST1042A04

SCRFST1042E04

SCRLLR1109A11

SCRLLR1131G09

SCSBST3102D02

SCSFLR2009B01

SCSFLR2024E10

SCSFST1066F12

SCSFST1066G01

SCSFST3076A03

SCSGLV1008F06

SCSGST3120C09

SCSGST3120D12

SCUTLR2015E02

SCUTLR2023B01

SCVPLR2019D12

SCVPST1059D04

SCVPST1059F03

SCVPST1060B12

SCVPST1061D07

SCVPST1061D11

SCVPST1062G02

SCVPST1063C04
Putative pirin

ND

ND

thiamine biosynthetic enzyme 1-2 precursor

ND

putative cytochrome P450

translation initiation factor IF-2 homolog F2P3.9

nodulin-like protein

ND

ND

ND

peptidylprolyl isomerase (cyclophilin)-like

TEL1S.2

ND

ND

Similar to NAM like protein (AC005310)

ND

ND

ND

ND

ND

ND

ND

ND

putative nucleotide sugar epimerase

putative retroelement pol polyprotein 


\section{APÊNDICE 6 - Clones Selecionados da Variedade Susceptível (SP80-3280) com Indução em Dois Tempos do Experimento}

\begin{tabular}{|c|c|}
\hline $\begin{array}{c}6 \text { e } 24 \text { horas } \\
\text { CLONES SELECIONADOS }\end{array}$ & DESCRIÇÃO \\
\hline SCACAD1038F12 & Strong similarity to M4 protein \\
\hline SCACLR1130D06 & glutathione S-transferase GST 17 \\
\hline SCACLR1132B05 & eukaryotic cap-binding protein \\
\hline SCACLR2007E07 & ND \\
\hline SCACLR2007F07 & ND \\
\hline SCACLR2014G02 & IN2-2 protein \\
\hline SCAGLR2026B05 & ND \\
\hline SCAGLR2033D09 & ND \\
\hline SCBGLR1114F05 & ND \\
\hline SCBGST3103A07 & metallothionein-like protein type 2 \\
\hline SCBGST3110G10 & phosphoserine aminotransferase \\
\hline SCBGST3111D03 & ND F1C12.190 \\
\hline SCCCLR1C11A10 & temperature and salt responsive protein \\
\hline SCCCLR2C03A08 & ND \\
\hline SCCCST1C04E01 & ND \\
\hline SCEQLR1094H08 & ND \\
\hline SCJLST1021G01 & serine carboxypeptidase i precursor \\
\hline SCMCLR1125B03 & RNA polymerase subunit beta \\
\hline SCQGLR1088B08 & metallothionein-I gene transcription \\
\hline SCQGLR2032G06 & ND \\
\hline SCQSST1040G01 & patatin homolog T9J22.23 \\
\hline SCQSST3116B04 & P-rich protein Nt-SubC29 \\
\hline SCRFLR2037H03 & ND \\
\hline SCRFST1045D11 & ND \\
\hline SCRLLR1109F10 & 5-formyltetrahydrofolate cyclo-ligase-like \\
\hline SCRLLR1131C02 & ND; 33791-31527 \\
\hline SCSBST3095D11 & cytochrome P450 \\
\hline SCSFLR2016D02 & alpha-xylosidase precursor \\
\hline SCSFST1064C07 & cyclin D2.1 protein \\
\hline SCSFST1064D10 & ND \\
\hline SCSGLV1004A02 & ND \\
\hline SCSGLV1011C09 & ND \\
\hline SCSGST1068G03 & RNA-binding protein-like \\
\hline SCSGST3118G07 & ND \\
\hline SCUTST3085B04 & ND \\
\hline SCUTST3086B04 & calcium-dependent protein kinase \\
\hline
\end{tabular}


SCUTST3086F11 ubiquitin-specific protease 25

SCVPST1060G05 ND

SCVPST1062G03 serine/threonine specific protein kinase-like

30 minutos e 12 horas CLONES SELECIONADOS

SCACLR1127G10

SCBGLR1114C09

SCBGST3106D04

SCBGST3111B03

SCCCLB2003F07

SCCCLR2001C12

SCCCST3005C02

SCMCLR1122D04

SCMCST1054G04

SCMCST1055B08

SCMCST1058C01

SCQSLR1089B07

SCQSLR1090E05

SCRFLR2021A10

SCRFST1041B06

SCRFST1042D06

SCRFST1045A11

SCRUFL3068B02

SCSBST3094H08

SCSBST3098E12

SCSBST3102C05

SCSFHR1045B07

SCSFST1067F10

SCSGLV1009G12

SCSGST1068A11

SCSGST1071A08

SCSGST3120E04

SCUTST3092D07

SCUTST3092F01

SCVPST1060D07

ribosomal protein $\mathrm{S} 7$

ND; 10133-7338

ND

F1003.1

ND; 79476-81015

ND

ND

ND

ND

ND

ND

ND

transport inhibitor response-like protein

ND

ND

ND

ND

GF14-c protein

ND

HMG-CoA synthase

ND

1-aminocyclopropane-1-carboxylate oxidase Similar to Spinacia oleracea protein kinase aspartate aminotransferase, cytoplasmic protein kinase-like protein; 82138-86594 ND

ND

MutT domain protein-like

ND

pectinesterase-like protein

6 e 12 horas

CLONES SELECIONADOS

SCBGST3103E12

SCQSLR1089H04

SCMCLR1122H07

SCRLAD1140C02

SCUTST3084F04

aspartate transaminase

putative translation initiation factor IF-2

$\mathrm{NADH}$ dehydrogenase chain

receptor protein kinase

ribosomal protein $30 \mathrm{~S}$ subunit 
SCJFLR2036B10

SCVPST1063F01

SCQGST3123F12

SCCCST2004G01

SCVPST1062B04

SCVPST1063A12

SCMCST1052F10

SCUTST3089C09

SCMCST1051A11

SCSGLV1005E05

SCSGLV1005C06

SCRFLR2021H11

SCMCST1055D01

SCUTLR2023E12

SCMCST1050C12

SCACLR2029D05

SCJLLR2006A02

SCBGLR1114A02

SCAGLR2033C02

SCBGLR1114A09

SCMCLR1122F09

SCMCLR1124A06

SCMCST1056G08

SCQSLR1089F11

SCRLLR1109D12

SCSFST1067B01

SCUTLR2008D04

SCUTST3091G07

SCVPST1059G01

SCSFST1065B10
F12M16.22

F14D16.10

galactokinase GAL1

ND

ND

ND

ND

ND

ND

ND

proline-rich protein F26K10.180

protein kinase $(\mathrm{PK})$

putative alpha-L-arabinofuranosidase

Putative UDP-glucose glucosyltransferase

similarity to centromere

ND

transcription factor MYC7E

transport protein subunit-like

ND

ND

ND

ND

ND

ND

ND

ND

ND

ND

$\mathrm{ND}$

zhb0018.1

30 minutos e 6 horas CLONES SELECIONADOS

SCAGLR2026E05

SCAGLR2033A08

SCBGLR1098A11

SCBGLR1099A10

SCBGLR1113D03

SCBGLR1114G07

SCBGST3104D04

SCCCLR1C04A07

SCCCLR1C11G01

SCCCLR2C02B09

SCCCST3004H06

\section{DESCRIÇÃO}

ND

ND

ND

ND

ND

ND

putative protein kinase

ND

ND

pirin

ND 


$\begin{array}{ll}\text { SCJLLR1106G11 } & \text { ND } \\ \text { SCMCST1049D12 } & \text { ND } \\ \text { SCMCST1056D08 } & \text { ND } \\ \text { SCQGST3126E03 } & \text { ND } \\ \text { SCQSST3115C01 } & \text { putative reverse transcriptase } \\ \text { SCRFFL8037C01 } & \text { probable integral membrane protein } \\ \text { SCSBST3093D08 } & \text { ND } \\ \text { SCSFLR2009F10 } & \text { ND } \\ \text { SCSGST1068C11 } & \text { similarity to transcription factor } \\ \text { SCSGST1071C07 } & \text { glutathione peroxidase } \\ \text { SCSGST1071F03 } & \text { ND } \\ \text { SCSGST3120A07 } & \text { ND } \\ \text { SCUTLR2015G05 } & \text { ND } \\ \text { SCUTST3086B02 } & \text { transcription factor TINY homolog T13E15.5 } \\ \text { SCVPLR2012B03 } & \text { Similar to translation initiation factor IF2 } \\ \text { SCVPLR2019C01 } & \text { cell wall invertase; beta-fructosidase; Incw4 }\end{array}$

\begin{tabular}{cl} 
12 e 24 horas & \\
CLONES SELECIONADOS & \multicolumn{1}{c}{ DESCRIÇÃO } \\
\hline SCQGLR1087H04 & protein translation factor sui1 homolog \\
SCRLLR1109B07 & ND T28J14.6ND \\
SCVPST1061G07 & cullin-like protein T1NDP11.14.1 \\
SCBGST3112H12 & transcription factor EREBP1 \\
SCACLR1126F06 & MLA6 protein \\
SCACLR2029H09 & nonspecific lipid-transfer protein precursor \\
SCCCST3004H05 & ND \\
SCSFST3079E08 & F1N21.22 \\
SCSFST3082A04 & vesicle soluble NSF attachment protein receptor \\
SCUTST3091C04 & ND \\
SCJLLR1107B12 & ND \\
SCMCST1049F03 & ND \\
SCUTST3086A08 & ND \\
SCBGLR1100A10 & homeodomain transcription factor KNAT6 \\
SCSBST3094H07 & pyrophosphate-dep. phosphofructo-1-kinase-like \\
SCVPST1060E09 & ND \\
SCBGLR1115D07 & ring-box 1 \\
SCSFST3073C11 & putative protein kinase \\
SCEQLR1094G05 & myb-related protein 1 \\
SCCCLV1001A04 & ND \\
SCMCLR1123E07 & ADP-ribosylation factor-like protein \\
SCACLR1128A01 & ND \\
SCACLR1130H05 & ND \\
SCBGLR1120A10 & ND \\
SCBGST3109C07 & ND \\
&
\end{tabular}


SCBGST3112B11 ND

SCCCLR2001C11 ND

SCCCLV1002G12 ND

SCJFLR2035E10 ND

SCJFST1048G08 ND

SCJLLR1104G01 ND

SCJLLR1106B10 RING zinc-finger protein, putative

SCMCST1049F12 ND

SCQSST3113F05 ND

SCSFST3079E04 ND

SCSGST1071B01 ND

SCSGST1071H06 ND

SCVPLR2027H01 ND

30 minutos e 24 horas

CLONES SELECIONADOS

SCACLR1126B11

SCACLR2007A09

SCAGLR2026C07

SCBGST3105E03

SCBGST3108C02

SCBGST3109F11

SCCCLR1121H02

SCCCLR1C08F09

SCCCST1C04A12

SCCCST1C04D02

SCCCST3006G04

SCEQLR1091C06

SCJFLR2036C01

SCJFST1047A05

SCJLLR1101A02

SCMCLR1123B11

SCMCLR1124B11

SCQSLR1089F09

SCQSST3114G02

SCRFST1046A04

SCRLLR1111F07

SCSBST3097E03

SCSFLR2016D09

SCSFST1067G11

SCSFST3073D12

SCSFST3074G07

SCSGLV1009E12

SCSGST1068C10

\section{ND}

ND

gene_id:MNB8.4 ND

mitochondrial energy transfer protein

adenylylsulfate kinase 1 , chloroplast precursor

ND

ND

ND

ribosomal RNA apurinic site specific lyase

St12p protein

ND

ND

ND

ND

histone H2A.F/Z

ND

ND

cim1 protein homolog F26K10.130

ND

receptor kinase-like protein

ND; 50315-51862

embryogenesis transmembrane protein

ND

ND

ND

ND

ND

ND 
SCUTST3087E08 DSPTP1 protein

SCUTST3090C07 ND

SCUTST3131H12 ND

SCVPLR2005H12 ND

SCVPLR2027C08 ND

SCVPST1059H08 ND

SCVPST1063C07 putative receptor-like protein kinase

SCVPST1063G11 adenosine kinase-like protein 


\section{APÊNDICE 7 - Clones Selecionados da Variedade Susceptível (SP80-3280) com Indução em Três Tempos do Experimento}

\begin{tabular}{cl}
\hline 30 minutoS, 6 e 12 horas & \\
CLONES SELECIONADOS & \\
\hline SCACLR1127D01 & F27J15.7 \\
SCACLR1130D02 & putative protein kinase \\
SCJFLR2035H01 & UDP-glucuronyltransferase-I \\
SCJFRT2055F06 & ND \\
SCJLLR2020F11 & ND \\
SCMCLR1123E05 & ND \\
SCMCLR1124G01 & ND \\
SCMCST1049B01 & ND \\
SCMCST1056F10 & ND \\
SCQGST3125C01 & ND \\
SCSBST3102C02 & ND \\
SCSGLV1011C06 & ND \\
SCSGST1071F05 & ND \\
SCSGST1071G01 & CYTOCHROME P450 71C4 \\
\hline & \\
\hline 30 minutoS, 6 e 24 horas & \\
CLONES SELECIONADOS & \\
\hline SCCCLR2002D06 & acyltransferase homolog \\
SCCCST1C03E09 & ND \\
SCCCST3001B03 & ND \\
SCJFLR2035A07 & tonoplast intrinsic protein; ZmTIP1 \\
SCJFLR2036G07 & putative pollen allergen \\
SCJLLR1105F12 & DnaJ-like protein \\
SCMCLR1122B09 & ND \\
SCMCST1052G07 & ND \\
SCQGLR2025H11 & ND \\
SCRFLR2034B05 & ND \\
SCRFST1046H11 & ND \\
SCSBRT3040B04 & subtilisin/chymotrypsin inhibitor \\
SCSFLR2009H03 & ND \\
SCSGLV1008B08 & F12K11.18 \\
SCUTLR2015G12 & putative auxin-induced protein \\
SCUTST3092D12 & ND \\
SCVPST1062H12 & ND \\
&
\end{tabular}




\begin{tabular}{|c|c|}
\hline $\begin{array}{l}30 \text { minutos, } 12 \text { e } 24 \text { horas } \\
\text { CLONES SELECIONADOS }\end{array}$ & DESCRIÇÃO \\
\hline SCACLR1126D09 & 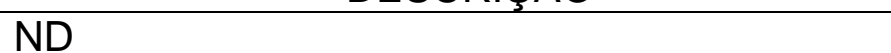 \\
\hline SCACLR1130A07 & ND \\
\hline SCBGLR1114A03 & ND \\
\hline SCBGLR1114E09 & ND \\
\hline SCBGLR1118A11 & CRS1 \\
\hline SCBGST3106C01 & peroxidase 4 precursor \\
\hline SCBGST3108C09 & SSRP1 protein \\
\hline SCCCLR1C04A06 & ND \\
\hline SCCCLR2004B05 & lipase-like protein \\
\hline SCEQLR1091C05 & ND \\
\hline SCMCST1051C10 & similarity to nephropathic cystinosis \\
\hline SCQSST1039E12 & receptor-like protein kinase \\
\hline SCQSST3115A03 & ND \\
\hline SCSFST3081H12 & iron sulfur subunit of succinate dehydrogenase \\
\hline SCSFST3082D06 & ND \\
\hline SCSGST1069D04 & putative transcription factor \\
\hline SCSGST3119C04 & ND \\
\hline SCUTST3130D05 & ND \\
\hline 6,12 e 24 horas & \\
\hline CLONES SELECIONADOS & DESCRIÇÃO \\
\hline SCBGLR1100B04 & ND \\
\hline SCCCLR1C06A09 & putative aphid transmission factor \\
\hline SCCCST3001H10 & RNA-binding protein \\
\hline SCCCST3005H10 & ND \\
\hline SCJFLR2036A02 & ND \\
\hline SCJLLR1101E10 & ND \\
\hline SCJLLR1103B01 & ND \\
\hline SCJLLR2006E12 & ND \\
\hline SCMCST1049A07 & ND \\
\hline SCQGST3124D03 & phospho-2-dehydro-3-deoxyheptonate aldolase \\
\hline SCQGST3124H11 & RING-H2 finger protein RHA3a \\
\hline SCRFLR2038H11 & ND \\
\hline SCSFST1066A11 & ND \\
\hline SCSFST3077F12 & EC 5.3.1.16 \\
\hline SCSFST3079B04 & putative senescence-associated protein 5 \\
\hline SCUTST3131H03 & ND \\
\hline SCVPST1063F10 & AMP-binding protein \\
\hline
\end{tabular}




\section{APÊNDICE 8 - Clones Selecionados da Variedade Susceptível (SP80-3280) com Indução nos Quatro Tempos do Experimento}

\begin{tabular}{cl}
\hline CLONES SELECIONADOS & \multicolumn{1}{c}{ DESCRIÇÃO } \\
\hline SCBGLR1114G12 & ARF2 \\
SCCCLR1C11A11 & probable heat shock protein EMB1 \\
SCCCLV1001A06 & non-LTR retroelement reverse transcriptase \\
SCCCLV1003E11 & ND \\
SCCCST2003D03 & ND \\
SCCCST3006B09 & ND \\
SCMCST1049B12 & ND \\
SCMCST1049E02 & ND \\
SCMCST1055F12 & ND \\
SCSBST3096H07 & isoflavone reductase homolog IRL \\
SCSGLV1006A10 & ND \\
SCSGLV1007E05 & ND \\
SCVPST1062A07 & ND \\
\hline
\end{tabular}




\section{APÊNDICE 9 - Clones Selecionados da Variedade Tolerante (SP81-3250) com Indução em Apenas um Tempo}

\begin{tabular}{|c|c|}
\hline $\begin{array}{c}30 \text { minutos } \\
\text { CLONES SELECIONADOS }\end{array}$ & DESCRIÇÃO \\
\hline SCACLR1126C11 & ND \\
\hline SCACLR1126D01 & ND \\
\hline SCACLR1126F06 & MLA6 protein \\
\hline SCACLR1128C10 & ND \\
\hline SCACLR1130A09 & ND \\
\hline SCACLR1132B05 & eukaryotic cap-binding protein \\
\hline SCAGLR2011B01 & CGI-129 protein \\
\hline SCAGLR2026F12 & ND \\
\hline SCAGLR2033H01 & ND \\
\hline SCBFAD1096D10 & peroxidase 1 \\
\hline SCBFLR1039C08 & beta-1,3-glucanase precursor \\
\hline SCBGLR1097G12 & putative helicase \\
\hline SCBGLR1116D02 & ND \\
\hline SCBGLR1117B12 & ND \\
\hline SCBGST3108C09 & SSRP1 protein \\
\hline SCBGST3110B01 & MYB-like DNA-binding domain protein \\
\hline SCCCLR1C08F09 & ND \\
\hline SCCCLR2002F12 & ND \\
\hline SCCCST1C01B10 & ND \\
\hline SCCCST1C04H05 & putative trehalose-6-phosphate synthase \\
\hline SCCCST3006C02 & ND \\
\hline SCEPRT2045F01 & glutathione S-transferase GST 22 \\
\hline SCEQLR1093A05 & ND \\
\hline SCEZRT2020A03 & chaperonin; similar to GroEL protein \\
\hline SCJFAD1013H07 & transport inhibitor response-like protein \\
\hline SCJFLR2035E10 & ND \\
\hline SCJFLR2036D05 & ND \\
\hline SCJFST1048D12 & ND \\
\hline SCJLFL4100D06 & putative ferulate-5-hydroxylase; 62457-61828 \\
\hline SCJLLR1101E03 & ND \\
\hline SCJLLR1101F04 & ND \\
\hline SCJLLR1104G07 & ND \\
\hline SCJLLR1107D12 & ND \\
\hline SCJLLR1107E12 & nucleoid DNA-binding protein cnd41-like protein \\
\hline SCJLLR2013F01 & ND \\
\hline SCJLRT1015D05 & alcohol dehydrogenase 1 \\
\hline
\end{tabular}


SCMCLR1122G02

SCMCLR1125A07

SCMCSD1059D07

SCMCST1055D09

SCMCST1058B08

SCQGST3126E03

SCQGST3126E09

SCQSST1040F02

SCQSST3113D06

SCQSST3115A12

SCRFAM2127F03

SCRFLR2037C03

SCRFSD1023G05

SCRFST1042E09

SCRFST1043G03

SCRFST1045D01

SCRFST1045E10

SCRLLR1131F07

SCSBRT3038F01

SCSBST3093E04

SCSBST3098F02

SCSFST1065H03

SCSFST1066F08

SCSFST3076D07

SCSFST3077D09

SCSFST3078H05

SCSFST3081A09

SCSFST3082E05

SCSGAD1009F02

SCSGLV1007G11

SCSGLV1008C08

SCSGLV1008F06

SCSGLV1010C07

SCSGSB1005A06

SCSGST1069D04

SCSGST1071G03

SCSGST1072H12

SCSGST3118E05

SCSGST3119A07

SCSGST3121C08

SCSGST3121H10

SCUTLR2015D07

SCUTLR2023H07

SCUTST3088E11

SCUTST3090H08 calcium-dependent protein kinase

ND

chitinase III C10701

ND

ND

ND

ND

ND

ND

ND

allyl alcohol dehydrogenase

ND

pathogenesis related protein-1

ND

cell division protein $\mathrm{FtsH}$

transport protein homolog YUP8H12R.2

ND

ND

protein phosphatase $2 \mathrm{C}$

leucoanthocyanidin dioxygenase-like protein

fructose-bisphosphate aldolase

lectin-like protein kinase-like

putative ubiquitin protein

ND

probable protein kinase

VIP2 protein

ND

ND

cyclophylin-like protein

polygalacturonase inhibitor

ND

ND

ND

peroxidase

putative transcription factor

ND

ND

cinnamoyl-CoA reductase

ND

ND

ND

ND

ornithine carbamoyltransferase; OCTase

ND F1N13_40

probable ferrochelatase 
SCVPLB2086E09

SCVPLR2012B03

SCVPST1059H11

SCVPST1061A01

SCVPST1062H11
CYTOCHROME P450 71A9

Similar to translation initiation factor IF2

GMP synthase; 61700-64653

ND

myosin heavy chain-like protein

\begin{tabular}{cl}
\hline \multicolumn{1}{c}{ 6 horas } & \\
CLONES SELECIONADOS & DESCRIÇÃO \\
\hline SCACLR1128A03 & ND \\
SCACLR1128F07 & putative Na+/H+ antiporter \\
SCACLR1130C08 & ND \\
SCACLR1130G01 & ND \\
SCACLR1132D05 & histone H3 \\
SCACLR2022B11 & ND \\
SCACLR2022F07 & ND \\
SCACLR2029B07 & ND \\
SCACLR2029D05 & T4O12.23 \\
SCAGLR2018G12 & ND \\
SCAGLR2033B01 & carnitine racemase like protein \\
SCBFST3132A02 & histidyl-tRNA synthetase \\
SCBFST3132G09 & ND \\
SCBFST3133B05 & xyloglucan endo-1,4-beta-D-glucanase \\
SCBGLR1095H08 & ND \\
SCBGLR1099D01 & ND \\
SCBGLR1099E10 & ND \\
SCBGLR1100A06 & ND \\
SCBGLR1100D12 & ND \\
SCBGLR1114E09 & ND \\
SCBGLR1115B08 & protein kinase PK1 receptor-like \\
SCBGLR1115C11 & Similar to ATP-citrate-lyase \\
SCBGLR1118F05 & ND \\
SCBGLR1119E11 & ND \\
SCBGST3104C03 & ND \\
SCBGST3104C11 & ND \\
SCBGST3105C03 & ND \\
SCBGST3106E02 & putative gag-pol polyprotein; 99986-95160 \\
SCBGST3106G11 & putative cytosolic chaperonin, delta-subunit; \\
SCBGST3107A01 & ND \\
SCBGST3108C02 & adenylylsulfate kinase 1, chloroplast precursor \\
SCCCLR1C01C11 & AMP-activated protein kinase beta \\
SCCCLR1C07A03 & ND \\
SCCCLR2001G05 & ND \\
SCCCLR2003D03 & ND \\
SCCCLR2003H12 & ND \\
& \\
&
\end{tabular}




\begin{tabular}{|c|c|}
\hline SCCCLR2004A03 & ND \\
\hline SCCCLR2004B11 & ND \\
\hline SCCCLR2C02C02 & ethylene-responsive transcriptional coactivator-like \\
\hline SCCCLR2C03A08 & ND \\
\hline SCCCLV1001G09 & ND \\
\hline SCCCLV1003H07 & ND \\
\hline SCCCST1C01B03 & ND \\
\hline SCCCST1C04A12 & ribosomal RNA apurinic site specific lyase \\
\hline SCCCST1C05C08 & disease resistance protein RPM1 homolog \\
\hline SCCCST1C06C01 & lectin-like protein kinase-like \\
\hline SCCCST1C06H10 & sucrose synthase-1 \\
\hline SCCCST2002A02 & ND \\
\hline SCCCST3001C08 & ferredoxin iii precursor \\
\hline SCCCST3002D06 & ND \\
\hline SCCCST3003D12 & zinc finger protein, putative \\
\hline SCCCST3004A06 & ND \\
\hline SCCCST3083E07 & O-succinylhomoserine lyase \\
\hline SCEQLR1094F02 & 40S ribosomal protein S12 \\
\hline SCEQLR1094G05 & myb-related protein 1 \\
\hline SCEZFL5085C06 & GRAB1 protein \\
\hline SCJFST1047E11 & IAA13 protein \\
\hline SCJLLR1101A02 & histone H2A.F/Z \\
\hline SCJLLR1101A04 & ND \\
\hline SCJLLR1105C12 & ND \\
\hline SCJLLR1106C06 & contains similarity to nodulin \\
\hline SCJLLR1106F01 & ND \\
\hline SCJLLR1107F04 & ND \\
\hline SCJLLR2006A02 & transcription factor MYC7E \\
\hline SCJLLR2028F07 & ND \\
\hline SCMCLR1122B12 & ND \\
\hline SCMCLR1125E04 & contains similarity to protein kinase domains; \\
\hline SCMCST1049D01 & similarity to receptor protein kinase \\
\hline SCMCST1050F06 & ND \\
\hline SCMCST1053D07 & ND \\
\hline SCMCST1055F01 & ND \\
\hline SCQGLR1088F07 & wound-induced protein \\
\hline SCQGLR2010H04 & ND \\
\hline SCQGLR2025A09 & ND \\
\hline SCQGLR2025C06 & ND \\
\hline SCQGLR2025E02 & ND \\
\hline SCQGLR2025H11 & ND \\
\hline SCQGLR2032D03 & ND \\
\hline SCQGST3124F04 & ribosomal protein L18a, cytosolic \\
\hline SCQSST1039G08 & fatty acid elongase 1 \\
\hline SCRFLR2021A10 & ND \\
\hline
\end{tabular}




\begin{tabular}{|c|c|}
\hline SCRFLR2021B04 & ND \\
\hline SCRFLR2021E07 & ND \\
\hline SCRFST1041A02 & ND \\
\hline SCRFST1043A08 & cytochrome P-450-like protein \\
\hline SCRFST1045C11 & putative myosin \\
\hline SCRFST1045F11 & ND \\
\hline SCRFST1046E04 & ND \\
\hline SCRLLR1111E06 & ND \\
\hline SCRUFL3068B02 & GF14-c protein \\
\hline SCSBST3093E12 & ND \\
\hline SCSBST3095G12 & ND \\
\hline SCSBST3096H07 & isoflavone reductase homolog IRL \\
\hline SCSBST3099F02 & ND \\
\hline SCSBST3101D08 & ND \\
\hline SCSFLR2016D03 & ND \\
\hline SCSFST1066G08 & ND \\
\hline SCSFST1067B01 & ND \\
\hline SCSFST1067B12 & cytosolic monodehydroascorbate reductase \\
\hline SCSFST3073D09 & ND \\
\hline SCSFST3073H03 & ND \\
\hline SCSFST3074E02 & ND \\
\hline SCSFST3074E12 & ND \\
\hline SCSFST3077C10 & putative chromosome associated protein \\
\hline SCSFST3077G07 & myb-related protein ZM1 \\
\hline SCSFST3078E06 & ND \\
\hline SCSFST3079A10 & ND \\
\hline SCSFST3079E04 & ND \\
\hline SCSFST3082E10 & similar to putative reverse transcriptase \\
\hline SCSGLV1005E05 & ND \\
\hline SCSGLV1007D10 & ND \\
\hline SCSGLV1007E05 & ND \\
\hline SCSGLV1007G11 & Polygalacturonase inhibitor \\
\hline SCSGLV1008C01 & Putative protein kinase-like \\
\hline SCSGLV1008G05 & ND \\
\hline SCSGLV1008H05 & integral membrane protein-like \\
\hline SCSGST1068B10 & ND \\
\hline SCSGST1068F10 & ND \\
\hline SCSGST1069E06 & ND \\
\hline SCSGST1069F03 & ND \\
\hline SCSGST1070G05 & ND \\
\hline SCSGST1072A05 & ND \\
\hline SCSGST1072F10 & ND \\
\hline SCSGST1072G05 & ND \\
\hline SCSGST3119D05 & auxin-induced protein TGSAUR12 \\
\hline SCSGST3121D06 & ND \\
\hline
\end{tabular}




$\begin{array}{ll}\text { SCUTLR2008A12 } & \text { ND } \\ \text { SCUTLR2015G05 } & \text { ND } \\ \text { SCUTST3084G11 } & \text { ND } \\ \text { SCUTST3085B04 } & \text { ND } \\ \text { SCUTST3085B11 } & \text { ND } \\ \text { SCUTST3085E06 } & \text { putative annexin } \\ \text { SCUTST3086H01 } & \text { Cks1 protein } \\ \text { SCUTST3087E08 } & \text { DsPTP1 protein } \\ \text { SCUTST3089H10 } & \text { ND } \\ \text { SCUTST3130C10 } & \text { ND } \\ \text { SCUTST3131B08 } & \text { ND } \\ \text { SCUTST3131E02 } & \text { ND } \\ \text { SCVPLR2012A05 } & \text { ND } \\ \text { SCVPLR2019A05 } & \text { ND } \\ \text { SCVPLR2019C01 } & \text { cell wall invertase; beta-fructosidase } \\ \text { SCVPLR2019F01 } & \text { Similar to 60S ribosomal protein } \\ \text { SCVPLR2027A10 } & \text { ND } \\ \text { SCVPLR2027D12 } & \text { histone H3.2, MINOR } \\ \text { SCVPST1060B06 } & \text { ND } \\ \text { SCVPST1060D09 } & \text { ND } \\ \text { SCVPST1061C06 } & \text { Sucrose synthase, putative } \\ \text { SCVPST1061D07 } & \text { putative protein } \\ \text { SCVPST1061D09 } & \text { ND } \\ \text { SCVPST1061G03 } & \text { ND }\end{array}$

\begin{tabular}{ll}
\hline \multicolumn{1}{c}{12 horas } & \\
CLONES SELECIONADOS & \multicolumn{1}{c}{ DESCRIÇÃO } \\
\hline SCACLR1132B04 & dihydroxy-acid dehydratase \\
SCACLR2022G09 & DnaJ protein, putative \\
SCAGLR2033A08 & ND \\
SCBGLR1100E01 & ND \\
SCBGLR1112C12 & ND \\
SCBGLR1115C02 & ND \\
SCBGLR1115G03 & HISTONE H1 \\
SCBGST3110C04 & acyl-CoA oxidase \\
SCBGST3110H10 & ND \\
SCBGST3111C12 & chlorophyll a/b-binding protein precursor \\
SCBGST3111D03 & ND F1C12.190 \\
SCCCLR1C01A11 & probable tyrosine--tRNA ligase \\
SCCCLR1C02H03 & ND \\
SCCCLR1C11A11 & probable heat shock protein EMB1 \\
SCCCLR2001D04 & ND \\
SCCCLR2001D05 & Putative fucosyltransferase \\
SCCCLR2003H08 & ND
\end{tabular}




\begin{tabular}{|c|c|}
\hline SCCCLR2C01E07 & ND \\
\hline SCCCLV1001D01 & ATP dependent transmembrane transporter \\
\hline SCCCLV1003H08 & F1504.40 \\
\hline SCCCST1C03G07 & ND \\
\hline SCCCST3083H05 & ND \\
\hline SCEQLR1093E12 & ND \\
\hline SCJFHR1030B02 & choline monooxygenase precursor \\
\hline SCJFLR2036F02 & ND \\
\hline SCJFST1048H03 & ND \\
\hline SCJLLR2028F08 & ND \\
\hline SCMCST1052A03 & ND \\
\hline SCMCST1053D03 & Rab geranylgeranyl transferase like protein \\
\hline SCMCST1053F08 & ND \\
\hline SCMCST1054B02 & ND \\
\hline SCMCST1057G05 & ND \\
\hline SCMCST1058B09 & ND \\
\hline SCMCST1058C01 & ND \\
\hline SCMCST1058H11 & ND \\
\hline SCQGLR1088H10 & superoxide dismutase \\
\hline SCQGLR2017A12 & ND \\
\hline SCQGST3123E11 & ND \\
\hline SCQSSST3113C09 & ND \\
\hline SCRFST1042C02 & ND \\
\hline SCRLLR1109A11 & putative cytochrome P450 \\
\hline SCRLLR1109B09 & ND \\
\hline SCSFST1066E05 & ND \\
\hline SCSFST1067A09 & ND \\
\hline SCSFST1067E03 & ND \\
\hline SCSFST3075A09 & probable omega-3 fatty acid desaturase \\
\hline SCSGLV1005C06 & proline-rich protein F26K10.180 \\
\hline SCSGST1068C10 & ND \\
\hline SCSGST1071E08 & ND \\
\hline SCSGST1071H05 & ND \\
\hline SCSGST3117C10 & ND \\
\hline SCUTLR2008D11 & vesicle transport v-SNARE protein \\
\hline SCUTLR2030C12 & ND \\
\hline SCUTLR2030E07 & contains similarity to ribonucleoprotein \\
\hline SCUTLR2030H01 & ND \\
\hline SCUTST3085F01 & ND \\
\hline SCUTST3091G08 & putative AAA-type ATPase \\
\hline SCUTST3092D07 & MutT domain protein-like \\
\hline SCUTST3127B11 & putative chloroplast RNA helicase VDL isoform 1 \\
\hline SCUTST3129H10 & ND \\
\hline SCVPAM2069B10 & allene oxide synthase \\
\hline SCVPLR2012E06 & MADS box protein 1 \\
\hline
\end{tabular}


SCVPST1059A10

SCVPST1062F02

SCVPST1063A12

SCVPST1063G10

SCVPST1063H10
T19E23.13

ferredoxin VI precursor

ND

ND

ND
24 horas

CLONES SELECIONADOS

SCACLR1127A06

SCACLR1130C06

SCACLR1132G02

SCACLR2007A09

SCACLR2007D05

SCAGAM2123E05

SCAGLR2033H10

SCBFST3132A03

SCBGAD1028G08

SCBGLR1100A04

SCBGLR1100A10

SCBGLR1114B01

SCBGLR1115H09

SCBGST3104F06

SCBGST3105E03

SCBGST3106E07

SCBGST3107G04

SCBGST3108D07

SCBGST3111B03

SCCCFL5057C01

SCCCLR2001C11

SCCCLR2002A10

SCCCLR2002F06

SCCCLR2003H06

SCCCLR2C02D04

SCCCLV1002D06

SCCCLV1002H05

SCCCST1C03B10

SCCCST1C05B12

SCCCST1C05C01

SCCCST1C06B03

SCCCST3003E01

SCCCST3006H09

SCCCST3083E03

SCCCST3083G12

SCJFAD1014B07

\section{DESCRIÇÃO}

ND

cellulose synthase-8

ND

ND

putative phloem-specific lectin

probable ethylene-response protein

ND

ND

ND

ND

homeodomain transcription factor KNAT6

small nuclear ribonucleoprotein T30B22.5

Putative histone $\mathrm{H} 3$

carbonate dehydratase

mitochondrial energy transfer protein

ND

shoot meristemless

ND

ND

chitinase, class $\mathrm{V}$

ND

ND

ND

trehalose-6-phosphate phosphatase

germin-like protein 5

ND

ND

$60 S$ acidic ribosomal protein

ND

ND

putative glucosyltransferase

ND

ND

Contains PF|00561 alpha/beta hydrolase fold. sesquiterpene cyclase 1

ND 


$\begin{array}{ll}\text { SCJFST1047A05 } & \text { ND } \\ \text { SCJFST1048A01 } & \text { Putative ubiquitin-conjugating enzyme E2 } \\ \text { SCJFST1048H07 } & \text { ND } \\ \text { SCJLLR1101F10 } & \text { ND } \\ \text { SCJLLR1102F10 } & \text { MtN3 } \\ \text { SCJLLR1105F01 } & \text { putative D-amino acid dehydrogenase } \\ \text { SCJLLR1107H12 } & \text { contains similarity to ankyrin like protein } \\ \text { SCJLLR2013G04 } & \text { ND } \\ \text { SCMCFL507C04 } & \text { Contains similarity to a basic endochitinase } \\ \text { SCMCLR1122D11 } & \text { wound-induced protein } \\ \text { SCMCLR1124A06 } & \text { ND } \\ \text { SCMCLR1124C06 } & \text { ND } \\ \text { SCMCST1049A02 } & \text { contains similarity to ribonucleoprotein } \\ \text { SCMCST1049B11 } & \text { ND } \\ \text { SCMCST1053H04 } & \text { ND } \\ \text { SCMCST1054F06 } & \text { ND } \\ \text { SCMCST1055H12 } & \text { ND } \\ \text { SCMCST1056F10 } & \text { ND } \\ \text { SCQGHR1013D01 } & \text { chitinase } \\ \text { SCQGLR2032E04 } & \text { protein-l-isoaspartate o-methyltransferase } \\ \text { SCQGST3123H12 } & \text { ND } \\ \text { SCQSFL1129A07 } & \text { Sgt1 } \\ \text { SCQSLR1089B09 } & \text { MADS box-like protein } \\ \text { SCQSST1040B01 } & \text { cell cycle control crn (crooked neck) protein-like } \\ \text { SCQSST3113H01 } & \text { calcium/calmodulin-dependent protein kinase } \\ \text { SCQSST3114C11 } & \text { ND } \\ \text { SCQSST3114H08 } & \text { ubiquitin-activating enzyme } \\ \text { SCRFAM2074G07 } & \text { ND } \\ \text { SCRFLR2021H11 } & \text { protein kinase (PK) } \\ \text { SCRFST1044C10 } & \text { ND } \\ \text { SCRFST1045D05 } & \text { ND } \\ \text { SCRFST1046F05 } & \text { ND } \\ \text { SCRLLR1109C08 } & \text { ND } \\ \text { SCRLLR1109H11 } & \text { ND } \\ \text { SCRLLR1110A03 } & \text { ND } \\ \text { SCRLLR1111F05 } & \text { signal peptidase } \\ \text { SCRLLR1111H07 } & \text { ND } \\ \text { SCRURZ3082B02 } & \text { vegetative storage protein } \\ \text { SCSBST3102B07 } & \text { cytochrome p450 90A1 } \\ \text { SCSBST3102E01 } & \text { ND } \\ \text { SCSFHR1045B07 } & 1 \text {-aminocyclopropane-1-carboxylate oxidase } \\ \text { SCSFLR2024C07 } & \text { ND } \\ \text { SCSFLR2024G05 } & \text { ND } \\ \text { SCSFLR2031A07 } & \text { ND } \\ \text { SCSFLR2031C04 } & \text { ND } \\ & \end{array}$




\begin{tabular}{ll} 
SCSFST1065E04 & ND \\
SCSFST1066E06 & ND \\
SCSFST3073A11 & ND \\
SCSFST3074D11 & nucleoside diphosphate kinase I \\
SCSFST3076H12 & ND \\
SCSFST3077B12 & ND \\
SCSFST3078A07 & ND \\
SCSFST3078F06 & ND \\
SCSFST3079E08 & ND \\
SCSFST3080G05 & ND \\
SCSGLV1009F07 & ND \\
SCSGLV1009G06 & ND \\
SCSGST1072B08 & leucyl aminopeptidase - parsley \\
SCSGST3119G10 & ND \\
SCSGST3120B03 & ND \\
SCSGST3120C07 & ND \\
SCSGST3121A10 & mitochondrial processing peptidase alpha-II chain \\
SCSGST3121E03 & ND \\
SCUTFL1059C04 & pathogenesis-related protein \\
SCUTLR2015A02 & ND \\
SCUTLR2015B09 & nucleic acid binding protein \\
SCUTST3091D02 & ND \\
SCUTST3092G01 & ND \\
SCUTST3128E01 & contains similarity to RING zinc finger protein \\
SCUTST3128E09 & 70 KD PEPTIDYLPROLYL ISOMERASE \\
SCUTST3128F05 & ND \\
SCVPHR1090F01 & serine-threonine protein \\
SCVPLR2027D05 & putative cytoskeleton-associated protein \\
SCVPST1061H08 & probable plasma membrane intrinsic protein \\
SCVPST1062F10 & ND \\
SCVPST1063B02 & ND \\
\hline
\end{tabular}




\section{APÊNDICE 10 - Clones Selecionados da Variedade Tolerante (SP81-3250) com Indução em Dois Tempos do Experimento}

\begin{tabular}{cl}
\hline \multicolumn{1}{c}{6 e 24 horas } & \\
CLONES SELECIONADOS & \multicolumn{1}{c}{ DESCRIÇÃO } \\
\hline SCACLR1130D02 & putative protein kinase \\
SCACLR1132B03 & ND \\
SCAGLR2011F11 & ND \\
SCBFRT1068F03 & ND \\
SCBGLR1095B01 & ND \\
SCBGLR1100F03 & acyl carrier protein F13M23.190 \\
SCBGLR1120B07 & one helix protein \\
SCBGST3103A07 & metallothionein-like protein type 2 \\
SCBGST3106F01 & fimbrin \\
SCBGST3109D05 & pectinacetylesterase homolog F14M4.24 \\
SCCCLR1C06A09 & putative aphid transmission factor \\
SCCCLR1C06C03 & ND \\
SCCCLR2004C05 & ND \\
SCCCLR2C02F08 & ND \\
SCCCLR2C03D06 & putative receptor-like protein kinase \\
SCCCLV1001H05 & ND \\
SCCCST1C02D04 & ND \\
SCCCST1C02D11 & ND \\
SCCCST3001D10 & ND \\
SCCCST3002E02 & ND \\
SCJFLR2035E02 & ND \\
SCJLLR1107B07 & putative mutator transposable element \\
SCMCLR1122E06 & ND \\
SCMCST1051C04 & ND \\
SCQGLR2032G12 & ND \\
SCQSST3113D04 & ND \\
SCRFLR2034B05 & ND \\
SCRFLR2034E07 & ND \\
SCRFLR2037E08 & cytosolic fructose-1,6-bisphosphatase \\
SCRFST1042E04 & ND \\
SCSBRT3039E08 & chitinase III C10501 \\
SCSBST3095A07 & ND \\
SCSBST3095B06 & inorganic phosphate transporter \\
SCSBST3098H04 & putative gag-pol polyprotein \\
SCSBST3100G06 & chlorophyll a-b binding protein m9 precursor \\
SCSFLR2009H03 & ND \\
&
\end{tabular}


SCSFLR2016E06

SCSFLR2016G11

SCSFST1064B07

SCSFST1066H04

SCSGST1068A02

SCSGST1069F12

SCSGST1069G11

SCSGST1072F06

SCSGST3120A03

SCSGST3120C12

SCUTST3084C11

SCUTST3130D10

SCUTST3130F09

SCVPLR2005D03

SCVPLR2027F01

SCVPST1060G09

SCVPST1062H04

SCVPST1063C04

SCVPST1063F10 similarity to mismatch repair protein

Contains similarity to proline-rich protein

transposon protein, putative

FKBP-like

extensin homolog T9E8.80

ND

ACTIN 2

ND

sugar transporter protein

ND

laccase

disease resistance protein RPM1 homolog

ND

ND

CONSTANS-like protein 2

putative pre-mRNA splicing factor atp-dependent

ND

putative retroelement pol polyprotein AMP-binding protein

30 minutos e 12 horas CLONES SELECIONADOS

SCACCL6010A10

SCAGLR2018A12

SCAGLR2026B05

SCBGLR1099B07

SCBGLR1112D10

SCBGLR1113H02

SCBGLR1118F08

SCBGRT3075E02

SCCCFL5065C01

SCCCLR2002B12

SCCCLR2C02A01

SCCCST1C03H09

SCCCST2004E05

SCEQLR1093D03

SCEQLR1094F04

SCJFLR2036B10

SCJLFL1051A09

SCJLLR1105G12

SCJLLR2020E01

SCMCST1053A06

SCMCST1054F10

SCQGST3125E10

\section{DESCRIÇÃO}

nuclear cap-binding protein CBP80

ND

ND

ND

ND

ubiquinol-cytochrome $\mathrm{c}$ reductase complex

ND

putative 60S ribosomal protein L22

probable transcription factor

ND

putative wound-induced protein

putative cytochrome P450

similarity to a dimethylaniline monooxygenase

ND

ND

ND

vegetative storage protein

elongation factor Ts

ND

protein kinase-like protein

ND

zinc finger protein 
SCRFLR2021E03

SCRFST1042A08

SCRFST1045H03

SCSBST3100A09

SCSFSB1102B07

SCSFSB1102C09

SCSFST1066A05

SCSFST3075H02

SCSFST3076A03

SCSFST3079A05

SCSFST3081A11

SCSGAD1009A05

SCSGAM2103C03

SCSGLV1004D10

SCSGRZ3063E01

SCSGST1068A01

SCSGST1069H03

SCSGST3119B03

SCUTLR2008D09

SCUTST3087E10

SCVPRZ3025F04

SCVPST1059H08
ND

ND

ND

ND

2,3-bisphosphoglycerate mutase

Similar to glucan endo-1,3-beta-glucosidase

coatomer complex subunit

ND

TEL1S.2

ND

$\mathrm{ND}$

putative receptor-like protein kinase

calcium sensor protein, calcineurin-like

ND

ARGININE DECARBOXYLASE

Nt-iaa2.3 deduced protein

ND

ent-kaurene oxidase

ND

non-LTR retroelement reverse transcriptase uncoupling protein mitochonrial ND

\begin{tabular}{|c|c|}
\hline $\begin{array}{c}6 \text { e } 12 \text { horas } \\
\text { CLONES SELECIONADOS }\end{array}$ & DESCRIÇÃO \\
\hline SCACLR1130F05 & ND \\
\hline SCACLR2007F07 & ND \\
\hline SCACLR2022G06 & ND \\
\hline SCBGLR1115D07 & ring-box 1 \\
\hline SCBGLR1117D09 & ND \\
\hline SCBGLR1120G07 & ND \\
\hline SCBGST3104B12 & transposase DOPA \\
\hline SCBGST3109F11 & ND \\
\hline SCBGST3111B08 & ND \\
\hline SCCCLR1C03G05 & ND \\
\hline SCCCLR2002D11 & ND \\
\hline SCCCLV1001E06 & ND \\
\hline SCCCST1C02E11 & ND \\
\hline SCCCST3001E01 & ND \\
\hline SCEQLR1094G07 & serine carboxypeptidase ii-3 precursor \\
\hline SCJFST1048E06 & ND \\
\hline SCJLLR1102G08 & ND \\
\hline SCJLLR1105H10 & ND \\
\hline SCJLLR1106D03 & ND \\
\hline
\end{tabular}




$\begin{array}{ll}\text { SCJLLR2006C07 } & \text { ND } \\ \text { SCMCLR1125B03 } & \text { RNA polymerase subunit beta } \\ \text { SCMCST1049B01 } & \text { ND } \\ \text { SCMCST1050A07 } & \text { ND } \\ \text { SCMCST1051A11 } & \text { ND } \\ \text { SCMCST1053D08 } & \text { ND } \\ \text { SCMCST1054B12 } & \text { ND } \\ \text { SCMCST1056A11 } & \text { ND } \\ \text { SCQGLR2025E01 } & \text { ND } \\ \text { SCQGLR2032G07 } & \text { ND } \\ \text { SCQGST3125C05 } & \text { metallothionein } \\ \text { SCQGST3126F06 } & \text { ND } \\ \text { SCQSRT3054H12 } & \text { probable germin protein 4 } \\ \text { SCQSST1040E04 } & \text { ND } \\ \text { SCRFLR2021D11 } & \text { ND } \\ \text { SCRFSB1021F11 } & \text { abscisic acid-induced protein HVA22 } \\ \text { SCRFST1041C03 } & \text { ND } \\ \text { SCRFST1042D06 } & \text { ND } \\ \text { SCRFST1042D08 } & \text { serine/threonine-specific receptor protein kinase } \\ \text { SCRFST1044D02 } & \text { omega-6 fatty acid desaturase } \\ \text { SCSBST3100B06 } & \text { putative clathrin heavy chain } \\ \text { SCSFLR2024D09 } & \text { 50S ribosomal protein L24 } \\ \text { SCSFST1064C10 } & \text { dnaK-type molecular chaperone hsp70 } \\ \text { SCSFST3073C11 } & \text { putative protein kinase } \\ \text { SCSFST3074D01 } & \text { flavonoid 3',5'-hydroxylase } \\ \text { SCSFST3075D07 } & \text { ND } \\ \text { SCSFST3082E09 } & \text { ND } \\ \text { SCSGST1068F12 } & \text { RNA helicase, putative; 27866-23496 } \\ \text { SCSGST3118F01 } & \text { ND } \\ \text { SCSGST3120D12 } & \text { Similar to NAM like protein (AC005310) } \\ \text { SCSGST3121E07 } & \text { UMP/CMP kinase a } \\ \text { SCUTST3091A01 } & \text { Similar to Secale chloroplast ribosomal protein } \\ \text { SCUTST3128B07 } & \text { ND } \\ \text { SCUTST3130A02 } & \text { ND } \\ \text { SCVPLR2027F07 } & \text { ND } \\ \text { SCVPST1059D05 } & \text { ND } \\ \text { SCVPST1063C05 } & \text { retroelement pol polyprotein-like } \\ & \end{array}$

30 minutos e 6 horas CLONES SELECIONADOS SCACLR1126E04 SCACLR1127D05 SCACLR2007E07 SCAGLR2033G11 DESCRIÇÃO

ND putative nucleosome assembly protein ND ND 


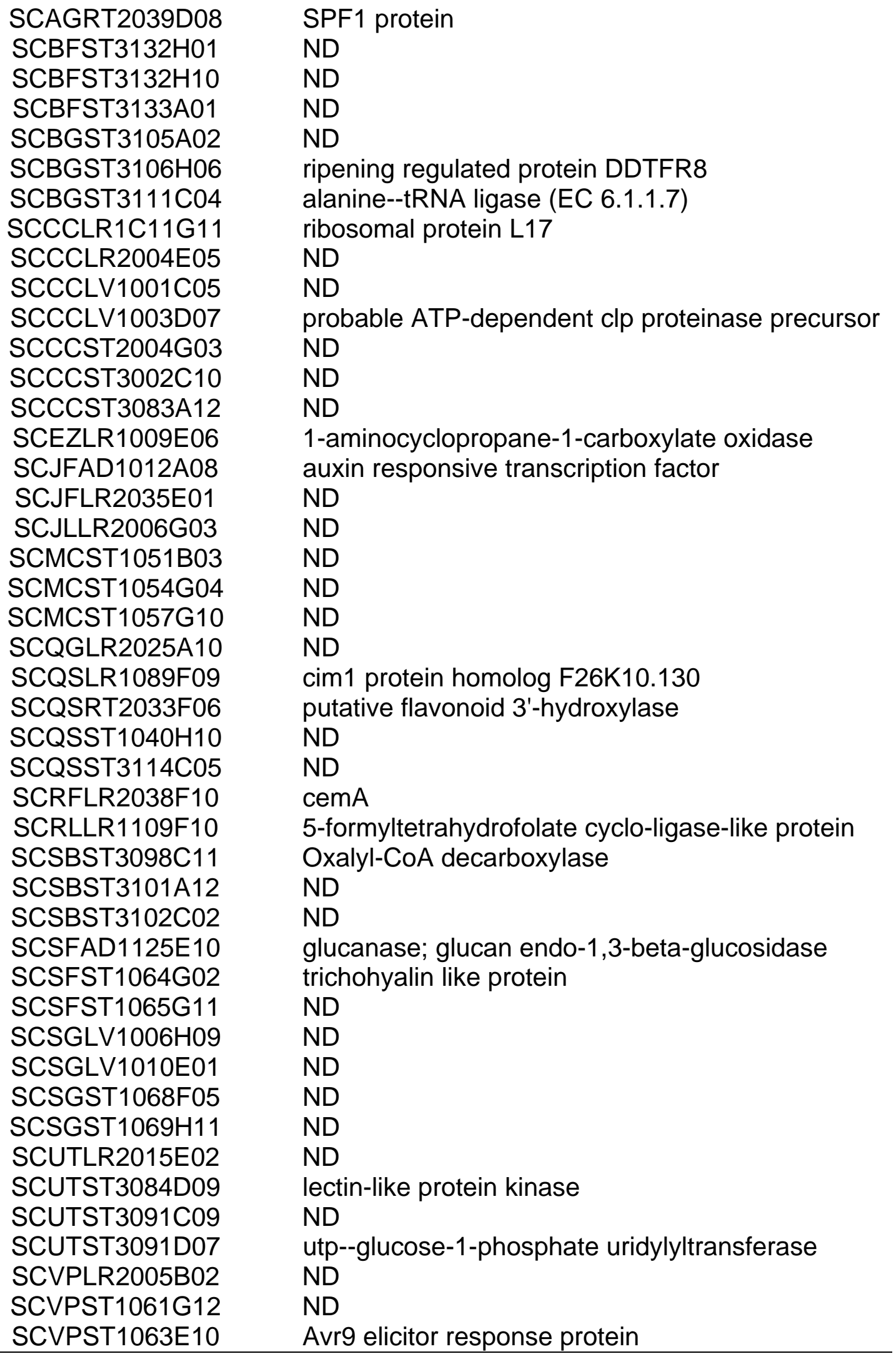




\begin{tabular}{|c|c|}
\hline $\begin{array}{c}12 \text { e } 24 \text { horas } \\
\text { CLONES SELECIONADOS }\end{array}$ & DESCRIÇÃO \\
\hline SCACLR2022G07 & ND \\
\hline SCACLR2029H09 & putative nonspecific lipid-transfer protein \\
\hline SCBGLB2015H05 & AP2 domain transcription factor-like protein \\
\hline SCBGLR1097H10 & ND \\
\hline SCBGLR1113H06 & ND \\
\hline SCBGLR1117F05 & ND \\
\hline SCBGST3103F08 & ND \\
\hline SCBGST3104D04 & putative protein kinase \\
\hline SCBGST3111G05 & ND \\
\hline SCCCLR1C01G12 & PPR-repeat protein, putative \\
\hline SCEPAM1023F09 & xyloglucan endo-1,4-beta-D-glucanase XTR-2 \\
\hline SCEQRT1024F02 & peroxidase R15 \\
\hline SCEZLR1031G08 & nonspecific lipid-transfer protein precursor \\
\hline SCJFLR2035H04 & calmodulin \\
\hline SCJFST1048F09 & ND \\
\hline SCJFST1048G05 & Similar to nodulins and lipase \\
\hline SCJLLR1102G03 & ND \\
\hline SCJLLR1103G12 & ND \\
\hline SCJLLR1104B07 & ND \\
\hline SCJLLR1108C11 & putative U2 snRNP auxiliary factor; 19096-22891 \\
\hline SCMCLR1122F09 & ND \\
\hline SCMCST1052E09 & disease resistance gene homolog $9 \mathrm{~N}$ \\
\hline SCMCST1057D06 & ND \\
\hline SCMCST1058H03 & ND \\
\hline SCQGLR2010G04 & ABC transporter-like protein \\
\hline SCQGLR2025E03 & zinc finger transcription factor WRKY1 \\
\hline SCQGLR2025H10 & probable myb factor \\
\hline SCQGST3124F05 & ND \\
\hline SCQGST3125F05 & small heat shock protein Hsp23.6 \\
\hline SCRFST1043C03 & ND \\
\hline SCRLLR1131C09 & ND \\
\hline SCRURT3061H09 & protein kinase \\
\hline SCSFST1067E08 & ND \\
\hline SCSFST3077B02 & beta-expansin \\
\hline SCSFST3081H12 & iron sulfur subunit of succinate dehydrogenase \\
\hline SCSGLV1004A12 & putative anthocyanin 5-O-glucosyltransferase \\
\hline SCSGST1071E07 & pectin acetylesterase \\
\hline SCUTRZ3070E07 & hydroperoxide lyase \\
\hline SCUTST3127E12 & ND \\
\hline SCUTST3127H10 & ND \\
\hline SCUTST3129E06 & ND \\
\hline SCVPST1060H12 & plasma membrane Ca2+-ATPase \\
\hline
\end{tabular}




\begin{tabular}{cl} 
SCVPST1061D11 & ND \\
SCVPST1062C07 & long chain acyl-CoA synthetase \\
\hline & \\
\hline 30 minutos e 24 horas & \\
CLONES SELECIONADOS & \\
\hline SCACLR1126D05 & ND \\
SCBGLR1097A04 & ND \\
SCBGLR1100H06 & ND \\
SCBGST3105E08 & ND \\
SCCCLR1C01A04 & ND \\
SCCCLR2001H11 & ND \\
SCCCST1C05F01 & ND \\
SCEQLB2016C06 & ND \\
SCEQLR1093D07 & ND \\
SCEZFL5086F01 & calcium-binding protein \\
SCEZST3149F10 & phenylalanine ammonia-lyase \\
SCJFLR2035A07 & tonoplast intrinsic protein; ZmTIP1 \\
SCJFST1047C06 & probable carboxyl-terminal proteinase \\
SCJLLR1104H11 & ND \\
SCJLLR1106E04 & ND \\
SCJLLR2013C09 & ND \\
SCJLLR2020E05 & ND \\
SCMCLR1122D05 & transcription initiation factor IIA gamma chain \\
SCMCLR1124B11 & ND \\
SCQGRT1042E04 & $1,3-$ beta-glucanase PRm 6b \\
SCQGST3124D03 & phospho-2-dehydro-3-deoxyheptonate aldolase 1 \\
SCQGST3125C08 & amidase \\
SCRFAD1021H07 & ND \\
SCRFLR2034B04 & ND \\
SCRFLR2038A11 & ND \\
SCRFLR2038H12 & ND \\
SCRFST1045D11 & ND \\
SCRLLR1131F03 & plastocyanin precursor \\
SCSFST3075E04 & protein kinase C inhibitor (PKCl) \\
SCSGLV1009F02 & ND \\
SCSGST3120E07 & ND \\
SCSGST3120G11 & receptor-like protein kinase 1 \\
SCSGST3121B02 & nucleoid DNA-binding protein cnd41-like protein \\
SCUTST3085G03 & ND \\
SCUTST3086B02 & transcription factor TINY homolog T13E15.5 \\
SCUTST3131H06 & ND \\
& \\
& \\
\hline
\end{tabular}




\section{APÊNDICE 11 - Clones Selecionados da Variedade Tolerante (SP81-3250) com Indução em Três Tempos do Experimento}

\begin{tabular}{|c|c|}
\hline $\begin{array}{l}30 \text { minutos, } 6 \text { e } 12 \text { horas } \\
\text { CLONES SELECIONADOS }\end{array}$ & DESCRIÇÃO \\
\hline SCAGLR2011C02 & fructokinase \\
\hline SCBGLR1113G03 & ND \\
\hline SCBGST3108H05 & homeobox protein rough sheath 1 \\
\hline SCBGST3111B04 & ND \\
\hline SCBGST3111D06 & ND \\
\hline SCJLLR1101E10 & ND \\
\hline SCMCLR1125A03 & ND \\
\hline SCMCST1057G07 & secreted glycoprotein 2 \\
\hline SCRFST1044D08 & ND \\
\hline SCRFST1045C12 & ND \\
\hline SCSBST3095H05 & ND \\
\hline SCSFLR2031A12 & mitochondrial energy transfer protein \\
\hline SCSFST3073H10 & ND \\
\hline SCSGLV1010D10 & ND \\
\hline SCSGST1068E08 & glucose-6-phosphate isomerase precursor \\
\hline SCSGST1071B11 & \\
\hline SCUTST3092C08 & putative phosphoserine aminotransferase \\
\hline SCVPST1063E06 & GTL1 \\
\hline 30 minutos, 6 e 24 horas & \\
\hline CLONES SELECIONADOS & DESCRIÇÃO \\
\hline SCBGLR1095H05 & ND \\
\hline SCBGLR1118B05 & heat shock-related protein precursor \\
\hline SCBGST3103H10 & ND \\
\hline SCBGST3105H07 & ND \\
\hline SCCCLR1C09D05 & ND \\
\hline SCCCLV1001C09 & ND \\
\hline SCCCRT3002H12 & chitinase \\
\hline SCCCST2002H08 & ND \\
\hline SCMCLR1125H02 & contains similarity to cytochrome $C$ oxidase \\
\hline SCRFST1043A02 & ND \\
\hline SCSFST1064B08 & ND \\
\hline SCSGLV1006C10 & ND \\
\hline SCSGRT2061C02 & putative gag/pol polyprotein \\
\hline SCUTLR2008H11 & probable wound-induced protein T9A4.6 \\
\hline SCUTLR2015A07 & ND \\
\hline SCVPST1060G07 & ND \\
\hline
\end{tabular}




\begin{tabular}{|c|c|}
\hline $\begin{array}{l}30 \text { minutos, } 12 \text { e } 24 \text { horas } \\
\text { CLONES SELECIONADOS }\end{array}$ & DESCRIÇÃO \\
\hline SCACLR1126F10 & ND \\
\hline SCCCFL3003E06 & cysteine proteinase inhibitor \\
\hline SCEPAM1051D07 & polyphenol oxidase \\
\hline SCEQLR1091C03 & ND \\
\hline SCJLLR1105A01 & histone H2A.4 \\
\hline SCMCST1050B09 & putative extensin-like protein \\
\hline SCRFRT3058D04 & Barwin, Basic Barley Seed Protein \\
\hline SCRFST1041E06 & heat shock protein 70 \\
\hline SCSBST3099H08 & ND \\
\hline SCSFST3079E11 & uncharacterized hematopoietic stem \\
\hline SCVPCL6064B05 & oleosin ZM-I \\
\hline 6,12 e 24 horas & \\
\hline CLONES SELECIONADOS & DESCRIÇÃO \\
\hline SCACLR1130H05 & ND \\
\hline SCACLR1132A05 & copper homeostasis factor \\
\hline SCACLR2014F07 & ND \\
\hline SCBGLR1114G12 & ARF2 \\
\hline SCBGLR1120D03 & ND \\
\hline SCBGST3111E01 & ND \\
\hline SCCCST2003D03 & ND \\
\hline SCCCST3002D02 & MLA6 protein \\
\hline SCJLLR1103E06 & ND \\
\hline SCMCST1057B07 & initiation factor $5 a$ \\
\hline SCQGSB1141F03 & ND \\
\hline SCQSST1040G01 & patatin homolog T9J22.23 \\
\hline SCQSST3114C01 & tubulin beta-7 chain \\
\hline SCQSSST3115B12 & ND \\
\hline SCRLLR1109F09 & ND \\
\hline SCSBST3094B10 & ND \\
\hline SCSBST3098E03 & ND \\
\hline SCSBST3100A01 & fructose-bisphosphatase-like protein \\
\hline SCSBST3101E06 & ND \\
\hline SCSGFL4189F01 & drought-induced protein Di19 \\
\hline SCSGLV1011H06 & ubiquitin conjugating protein \\
\hline SCSGST3121C03 & cysteine proteinase inhibitor \\
\hline SCUTLR2023D03 & ND \\
\hline SCUTST3127F05 & ND \\
\hline SCVPST1062G02 & putative nucleotide sugar epimerase \\
\hline
\end{tabular}




\section{APÊNDICE 12 - Clones Selecionados da Variedade Tolerante (SP81-3250) com Indução nos Quatro Tempos do Experimento}

\begin{tabular}{cl}
\hline CLONES SELECIONADOS & DESCRIÇÃO \\
\hline SCACLR2022D07 & ND \\
SCBGLR1097E10 & ND \\
SCBGLR1120G12 & histone H1 \\
SCBGST3105H05 & phosphoenolpyruvate translocator \\
SCCCST1C06D01 & S-receptor kinase M4I22.110 precursor \\
SCEQLR1092A01 & auxin-binding protein 4 precursor \\
SCJFST1047G04 & retroelement reverse transcriptase \\
SCQGLR1088D01 & ND \\
SCQGST3124A07 & ND \\
SCQGST3125F02 & pathogenesis-related protein F20M13.220 \\
SCQSLR1090D08 & ND \\
SCQSST3113A12 & ND \\
SCRFLR2038B09 & ND \\
SCRFST1044F07 & ND \\
SCRFST1046B03 & ND \\
SCSBST3093C10 & myb-related protein ZM1 \\
SCSBST3093G10 & ND \\
SCSBST3102G10 & ND \\
SCSFST1064C03 & ND \\
SCSFST3073C12 & vesicle-associated membrane protein \\
SCSFST3077H03 & ND \\
\hline
\end{tabular}




\section{APÊNDICE 13 - Clones Induzidos nas Duas Variedades: Susceptível (SP80-3280) e Tolerante (SP81-3250)}

\begin{tabular}{|c|c|}
\hline CLONE & DESCRIÇÃO \\
\hline SCACLR1126F06 & MLA6 protein \\
\hline SCACLR1128A03 & ND \\
\hline SCACLR1128C10 & ND \\
\hline SCACLR1130D02 & putative protein kinase \\
\hline SCACLR1130H05 & ND \\
\hline SCACLR1132B05 & eukaryotic cap-binding protein \\
\hline SCACLR1132D05 & HISTONE H3 \\
\hline SCACLR2007A09 & ND \\
\hline SCACLR2007E07 & ND \\
\hline SCACLR2007F07 & ND \\
\hline SCACLR2029D05 & ND \\
\hline SCACLR2029H09 & putative nonspecific lipid-transfer protein \\
\hline SCAGLR2011C02 & fructokinase \\
\hline SCAGLR2018G12 & ND \\
\hline SCAGLR2026B05 & ND \\
\hline SCAGLR2033A08 & ND \\
\hline SCBGLR1095H05 & ND \\
\hline SCBGLR1095H08 & ND \\
\hline SCBGLR1097H10 & ND \\
\hline SCBGLR1100A04 & ND \\
\hline SCBGLR1100A10 & homeodomain transcription factor KNAT6 \\
\hline SCBGLR1100D12 & ND \\
\hline SCBGLR1114E09 & ND \\
\hline SCBGLR1114G12 & ARF2 \\
\hline SCBGLR1115D07 & ring-box 1 \\
\hline SCBGST3103A07 & metallothionein-like protein type 2 \\
\hline SCBGST3104C11 & ND \\
\hline SCBGST3104D04 & putative protein kinase \\
\hline SCBGST3105A02 & ND \\
\hline SCBGST3105E03 & mitochondrial energy transfer protein \\
\hline SCBGST3106C01 & peroxidase 4 precursor \\
\hline SCBGST3107G04 & shoot meristemless \\
\hline SCBGST3108C02 & adenylylsulfate kinase 1 , chloroplast precursor \\
\hline SCBGST3108C09 & SSRP1 protein \\
\hline SCBGST3109F11 & ND \\
\hline SCBGST3111B03 & F1003.1 \\
\hline SCBGST3111B04 & ND \\
\hline SCBGST3111B08 & ND \\
\hline
\end{tabular}




$\begin{array}{ll}\text { SCBGST3111D03 } & \text { ND } \\ \text { SCCCLR1C01G12 } & \text { PPR-repeat protein, putative } \\ \text { SCCCLR1C06A09 } & \text { putative aphid transmission factor } \\ \text { SCCCLR1C08F09 } & \text { ND } \\ \text { SCCCLR1C09D05 } & \text { ND } \\ \text { SCCCLR1C11A11 } & \text { probable heat shock protein EMB1 } \\ \text { SCCCLR2001C11 } & \text { ND } \\ \text { SCCCLR2002D11 } & \text { ND } \\ \text { SCCCLR2004C05 } & \text { ND } \\ \text { SCCCLR2C01E07 } & \text { ND } \\ \text { SCCCLR2C02A01 } & \text { putative wound-induced protein } \\ \text { SCCCLR2C02B09 } & \text { pirin } \\ \text { SCCCLR2C03A08 } & \text { ND } \\ \text { SCCCST1C04A12 } & \text { ribosomal RNA apurinic site specific lyase } \\ \text { SCCCST1C06D01 } & \text { S-receptor kinase M4l22.110 precursor } \\ \text { SCCCST2003D03 } & \text { ND } \\ \text { SCCCST3002D02 } & \text { MLA6 protein } \\ \text { SCCCST3003E01 } & \text { ND } \\ \text { SCCCST3083A12 } & \text { ND } \\ \text { SCCCST3083H05 } & \text { ND } \\ \text { SCEQLR1092A01 } & \text { auxin-binding protein 4 precursor } \\ \text { SCEQLR1093E12 } & \text { arabinogalactan-like protein (U09556) } \\ \text { SCEQLR1094F02 } & 40 S \text { ribosomal protein S12 } \\ \text { SCEQLR1094G05 } & \text { myb-related protein 1 } \\ \text { SCEZLR1031G08 } & \text { nonspecific lipid-transfer protein precursor } \\ \text { SCEZRT2020A03 } & \text { chaperonin; similar to GroEL protein } \\ \text { SCJFAD1012A08 } & \text { auxin responsive transcription factor } \\ \text { SCJFAD1013H07 } & \text { transport inhibitor response-like protein } \\ \text { SCJFLR2035A07 } & \text { tonoplast intrinsic protein; ZmTIP1 } \\ \text { SCJFLR2035E10 } & \text { ND } \\ \text { SCJFLR2036B10 } & \text { ND } \\ \text { SCJFST1047A05 } & \text { ND } \\ \text { SCJFST1047C06 } & \text { probable carboxyl-terminal proteinase } \\ \text { SCJLLR1101A02 } & \text { histone H2A.F/Z } \\ \text { SCJLLR1101E10 } & \text { ND } \\ \text { SCJLLR1102G03 } & \text { ND } \\ \text { SCJLLR1102G08 } & \text { ND } \\ \text { SCJLLR1105A01 } & \text { histone H2A.4 } \\ \text { SCJLLR1106E04 } & \text { ND } \\ \text { SCJLLR1107E12 } & \text { nucleoid DNA-binding protein cnd41-like protein } \\ \text { SCJLLR1107F04 } & \text { ND } \\ \text { SCJLLR1108C11 } & \text { putative U2 snRNP auxiliary factor } \\ \text { SCJLLR2006A02 } & \text { transcription factor MYC7E } \\ \text { SCJLLR2006C07 } & \text { ND } \\ \text { SCJLLR2006G03 } & \text { ND } \\ & \end{array}$




$\begin{array}{ll}\text { SCJLLR2028F08 } & \text { ND } \\ \text { SCJLRT1015B03 } & \text { chitinase III C10150 } \\ \text { SCMCLR1122B12 } & \text { ND } \\ \text { SCMCLR1122F09 } & \text { ND } \\ \text { SCMCLR1124A06 } & \text { ND } \\ \text { SCMCLR1124B11 } & \text { ND } \\ \text { SCMCLR1124C06 } & \text { ND } \\ \text { SCMCLR1125A03 } & \text { ND } \\ \text { SCMCLR1125B03 } & \text { RNA polymerase subunit beta } \\ \text { SCMCST1049B01 } & \text { ND } \\ \text { SCMCST1051A11 } & \text { ND } \\ \text { SCMCST1053D08 } & \text { ND } \\ \text { SCMCST1054G04 } & \text { ND } \\ \text { SCMCST1056F10 } & \text { ND } \\ \text { SCMCST1058C01 } & \text { ND } \\ \text { SCMCST1058H11 } & \text { ND } \\ \text { SCQGLB2042B04 } & \text { SP8 binding protein homolog } \\ \text { SCQGLR1088H10 } & \text { Superoxide dismutase } \\ \text { SCQGLR2025H11 } & \text { ND } \\ \text { SCQGLR2032D03 } & \text { ND } \\ \text { SCQGST3124D03 } & \text { phospho-2-dehydro-3-deoxyheptonate aldolase 1 } \\ \text { SCQGST3125C08 } & \text { amidase } \\ \text { SCQGST3126E03 } & \text { ND } \\ \text { SCQGST3126E09 } & \text { ND } \\ \text { SCQSLR1089F09 } & \text { cim1 protein homolog } \\ \text { SCQSRT2033F06 } & \text { putative flavonoid 3'-hydroxylase } \\ \text { SCQSRT3054H12 } & \text { probable germin protein 4 } \\ \text { SCQSST1040G01 } & \text { patatin homolog } \\ \text { SCQSST3113A12 } & \text { ND } \\ \text { SCQSST3113D04 } & \text { ND } \\ \text { SCQSST3115B12 } & \text { ND } \\ \text { SCRFLR2021A10 } & \text { ND } \\ \text { SCRFLR2021H11 } & \text { protein kinase (PK) } \\ \text { SCRFLR2034B05 } & \text { ND } \\ \text { SCRFLR2038B09 } & \text { ND } \\ \text { SCRFST1041A02 } & \text { ND } \\ \text { SCRFST1041C03 } & \text { ND } \\ \text { SCRFST1042D06 } & \text { ND } \\ \text { SCRFST1042E04 } & \text { ND } \\ \text { SCRFST1045D11 } & \text { ND } \\ \text { SCRFST1046A04 } & \text { receptor kinase-like protein } \\ \text { SCRFST1046F05 } & \text { ND } \\ \text { SCRLLR1109A11 } & \text { putative cytochrome P450 } \\ \text { SCRLLR1109F09 } & \text { ND } \\ \text { SCRLLR1109F10 } & \text { 5-formyltetrahydrofolate cyclo-ligase-like protein }\end{array}$




$\begin{array}{ll}\text { SCRLLR1111C05 } & \text { ND } \\ \text { SCRLLR1111F07 } & \text { ND } \\ \text { SCRLLR1111H07 } & \text { ND } \\ \text { SCRUFL3068B02 } & \text { GF14-c protein } \\ \text { SCSBRT3039E08 } & \text { chitinase III C10501 } \\ \text { SCSBST3095B06 } & \text { inorganic phosphate transporter } \\ \text { SCSBST3096H07 } & \text { isoflavone reductase homolog irl } \\ \text { SCSBST3098C11 } & \text { Oxalyl-CoA decarboxylase } \\ \text { SCSBST3100G06 } & \text { chlorophyll a-b binding protein m9 precursor } \\ \text { SCSBST3101E06 } & \text { ND } \\ \text { SCSBST3102C02 } & \text { ND } \\ \text { SCSFHR1045B07 } & \text { 1-aminocyclopropane-1-carboxylate oxidase } \\ \text { SCSFLR2009H03 } & \text { ND } \\ \text { SCSFST1066E05 } & \text { ND } \\ \text { SCSFST1066F08 } & \text { putative ubiquitin protein } \\ \text { SCSFST1067B01 } & \text { ND } \\ \text { SCSFST3073C11 } & \text { putative protein kinase } \\ \text { SCSFST3075A09 } & \text { omega-3 fatty acid desaturase } \\ \text { SCSFST3076A03 } & \text { TEL1S.2 } \\ \text { SCSFST3077C10 } & \text { putative chromosome associated protein } \\ \text { SCSFST3079E04 } & \text { ND } \\ \text { SCSFST3079E08 } & \text { F1N21.22 } \\ \text { SCSFST3080G05 } & \text { ND } \\ \text { SCSFST3081H12 } & \text { iron sulfur subunit of succinate dehydrogenase } \\ \text { SCSFST3082E05 } & \text { ND } \\ \text { SCSFST3082E10 } & \text { similar to putative reverse transcriptase } \\ \text { SCSGAD1009A05 } & \text { putative receptor-like protein kinase } \\ \text { SCSGAD1009F02 } & \text { cyclophylin-like protein } \\ \text { SCSGLV1004A12 } & \text { putative anthocyanin 5-O-glucosyltransferase } \\ \text { SCSGLV1005C06 } & \text { proline-rich protein F26K10.180 } \\ \text { SCSGLV1005E05 } & \text { ND } \\ \text { SCSGLV1007E05 } & \text { ND } \\ \text { SCSGLV1008F06 } & \text { ND } \\ \text { SCSGLV1009E12 } & \text { ND } \\ \text { SCSGLV1009F07 } & \text { ND } \\ \text { SCSGRZ3063E01 } & \text { arginine decarboxylase } \\ \text { SCSGST1068C10 } & \text { ND } \\ \text { SCSGST1069D04 } & \text { putative transcription factor } \\ \text { SCSGST1071B11 } & \text { ND } \\ \text { SCSGST3120D12 } & \text { Similar to NAM like protein (AC005310) } \\ \text { SCUTLR2015E02 } & \text { ND } \\ \text { SCUTLR2015G05 } & \text { ND } \\ \text { SCUTLR2030C12 } & \text { ND } \\ \text { SCUTST3085B04 } & \text { ND } \\ \text { SCUTST3085F01 } & \text { ND } \\ & \end{array}$


SCUTST3086B02

SCUTST3087E08

SCUTST3091A01

SCUTST3091C09

SCUTST3092D07

SCUTST3127E12

SCUTST3130D10

SCVPLR2012B03

SCVPLR2019C01

SCVPLR2019F01

SCVPRZ3025F04

SCVPST1059H08

SCVPST1061D07

SCVPST1061D11

SCVPST1062G02

SCVPST1063A12

SCVPST1063C04

SCVPST1063F10

SCVPST1063H10 transcription factor TINY homolog T13E15.5

DsPTP1 protein

chloroplast ribosomal protein L12

ND

MutT domain protein-like

ND

disease resistance protein RPM1 homolog

Similar to translation initiation factor IF2

cell wall invertase; beta-fructosidase

$60 S$ ribosomal protein L11A

uncoupling protein mitochonrial

ND

ND

ND

putative nucleotide sugar epimerase

ND

putative retroelement pol polyprotein

AMP-binding protein 